\title{
The Church in Fourteenth-Century Iceland
}

\section{Ecclesiastical Administration, Literacy, and the Formation of an Elite Clerical Identity}

\author{
Erika Ruth Sigurdson \\ Submitted in accordance with the requirements for the degree of \\ Ph.D. \\ The University of Leeds \\ Institute for Medieval Studies
}

11 November, 2011 
The candidate confirms that the work submitted is her own and that appropriate credit has been given where reference has been made to the work of others.

This copy has been supplied on the understanding that it is copyright material and that no quotation from the thesis may be published without proper acknowledgement.

(C) 2011 University of Leeds and Erika Ruth Sigurdson 


\section{Acknowledgements}

A project such as this incurs many debts. I should begin by acknowledging the financial support (ORS, Tetley and Lupton scholarship) which made this project possible. To this, I will add my gratitude to my supervisors, Dr Alaric Hall and Prof. Graham Loud. Their support, constructive criticism, and generous supply of knowledge have made this thesis considerably better than it could have been without them. Prof. Andrew Wawn supervised my thesis in my first year, and was consistently generous with his knowledge and experience, as well as assistance with Icelandic translation.

Additionally, I would like to convey my gratitude to the Institute for Medieval Studies. Here I must specifically thank Dr Mary Swan, whose support and advice helped me navigate the conflicting demands of a postgraduate research programme. I must also thank Dr William Flynn, who provided a sympathetic ear, as well as encouragement, advice, and much-needed optimism. The users of the LePatourel room have been a constant source of friendly encouragement and good company throughout my time at Leeds, while the University of Leeds Old Norse Reading Group has provided a venue for like-minded Old Norse enthusiasts to translate and discuss Old Norse literature and related topics. I would particularly like to thank my friends and colleagues, Sheryl McDonald and Helen Price, who have been a constant source of shared ideas and enthusiasm for Iceland in the Middle Ages.

Finally, I must thank my family, friends, and especially my parents. Without their constant support I would not have been able to begin, let alone complete a project on this scale. I would also like to thank my partner, Jason Berg. He not only provided much-appreciated editorial advice, but has also been a constant support in my writing-up year. 


\begin{abstract}
This thesis examines the development of elite clerical culture in fourteenth-century Iceland. Following ecclesiastical reforms of the late thirteenth century (staðamál), a small number of clerics gained access to large farms (staðir) as benefices, and gained wealth and power from their new benefices. Over the course of the century, this small group developed a shared identity, one based on clerical values such as familiarity with canon law, as well as on a shared sense of interdependence and a new, clerical set of personal networks and connections. This thesis examines the development of this shared identity, particularly as expressed through clerical narrative writing, and through the role of ecclesiastical administration at the subepiscopal level (diocesan officers and the holders of major benefices).

Chapter 1 provides an introduction to current scholarly approaches to fourteenth-century Iceland, while discussing the historical context for the study of ecclesiastical administration and clerical identity. Chapter 2 surveys the primary sources which form the basis of this thesis. Chapter 3 is a study of the structure of the Icelandic Church, with a focus on the role of individual agents in shaping the development of ecclesiastical institutions. Chapter 4 consists of a social and cultural study of the sub-episcopal elite clergy in Iceland. The first part of this chapter examines the economic and social basis for the development of an elite clergy, while the second part provides an analysis of the social and cultural history of the subepiscopal elite, with a focus on the social networks of the sub-episcopal elite, and different types of relationship within these networks. Chapter 5 consists of a thematic study of Icelandic clergy in Norway; through an analysis of evidence for voyages to Norway undertaken by the sub-episcopal elite, I provide insight into the particular relationship between Iceland and Norway in the fourteenth century.
\end{abstract}




\section{Contents}

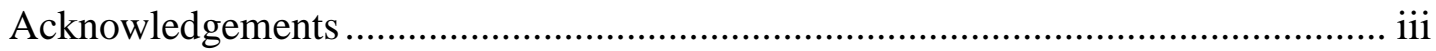

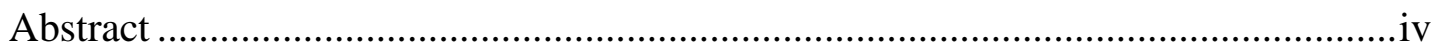

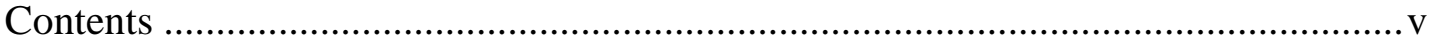

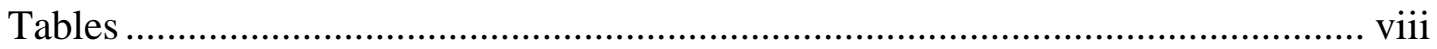

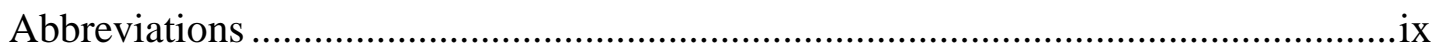

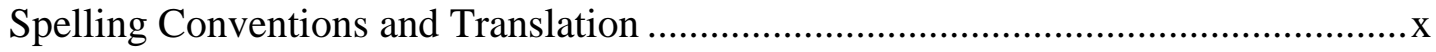

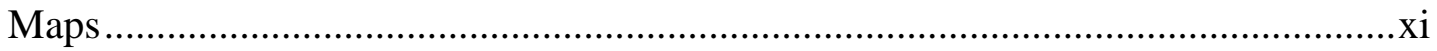

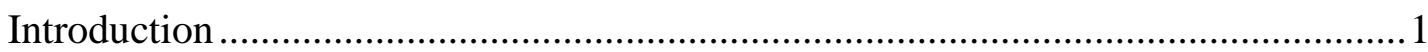

Chapter One: Iceland in the Fourteenth Century …................................................

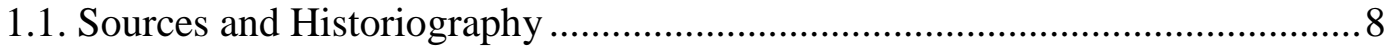

1.2. Government: Iceland and the Kings of Norway ......................................... 15

1.2.1. The End of the Icelandic Commonwealth.............................................. 16

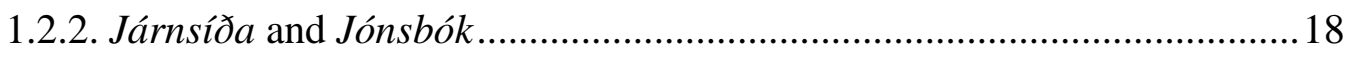

1.2.3. The Norwegian Crown and Political Restructuring 1319-97 ..................20

1.3. The Aristocracy in Iceland and the Administration of Iceland .......................23

1.3.1. The Administration of Iceland after 1264 ..............................................2 24

1.3.2. Leiguhirðstjórar (the rental governors) ................................................28

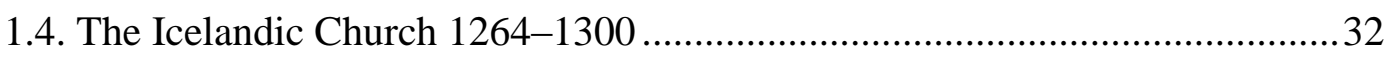

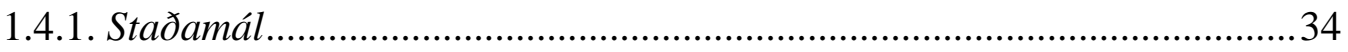

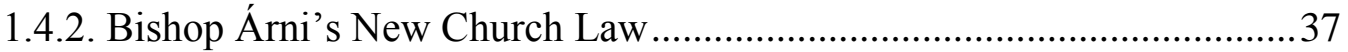

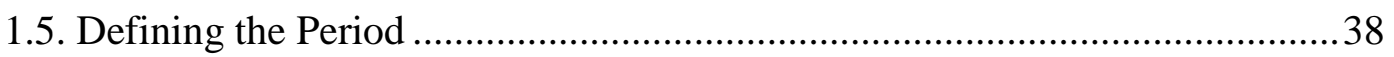

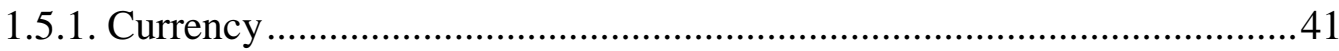

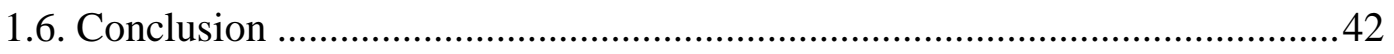

Chapter Two: Sources and Authorship: The Intellectual Milieu ..............................44

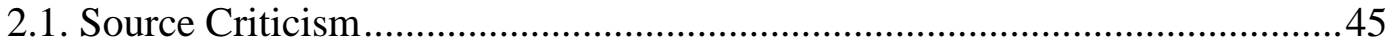

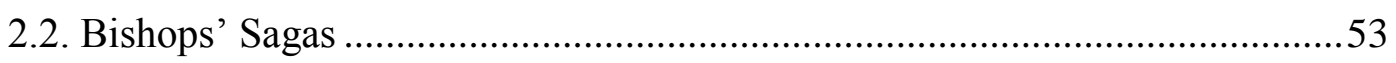

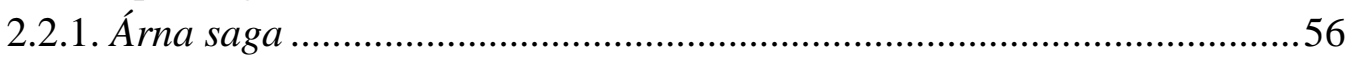

2.2.2. Guðmundar saga D (Guðmundar saga Arngríms Brandssonar).............57

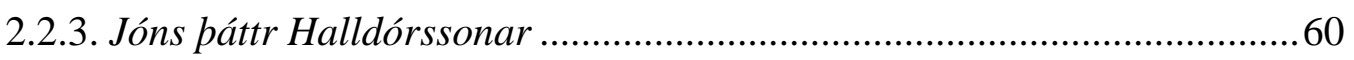

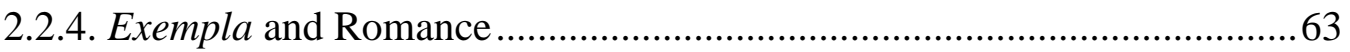

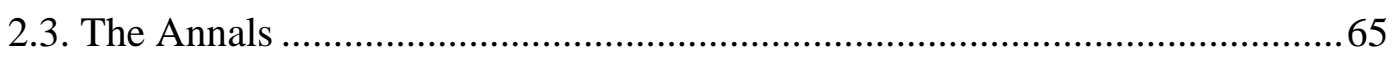

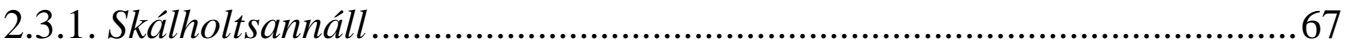

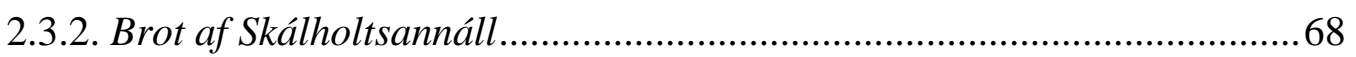

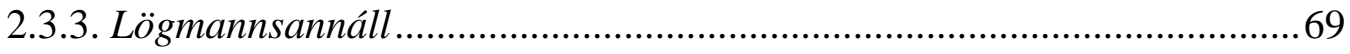

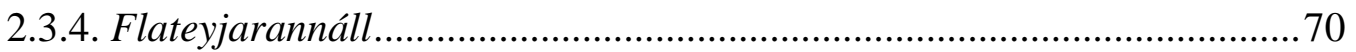




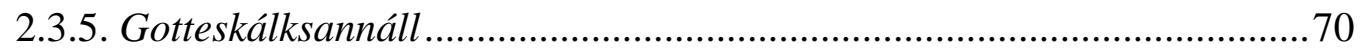

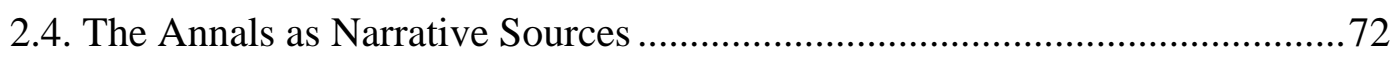

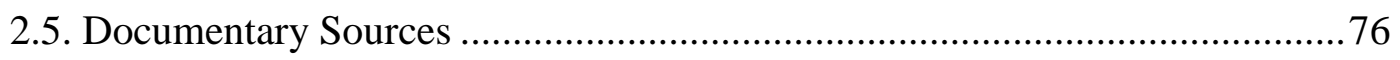

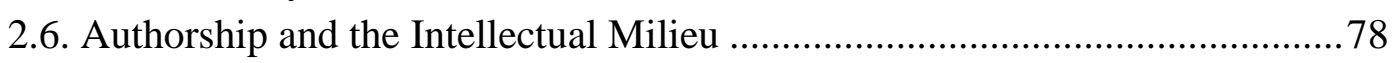

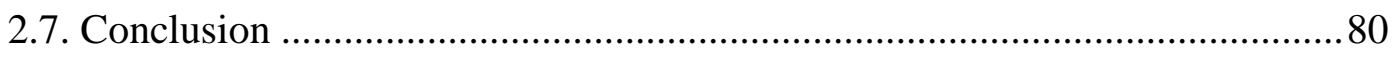

Chapter Three: Structure of the Icelandic Church ................................................... 81

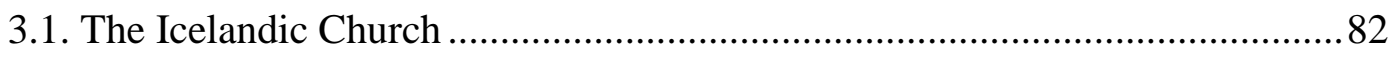

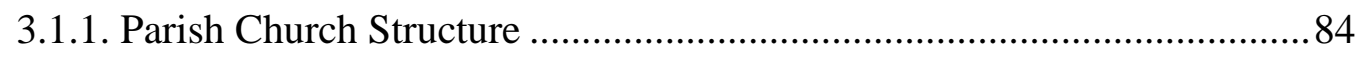

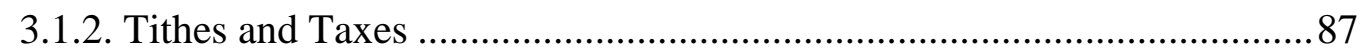

3.1.3. Staðir, Bandarkirkjur, and Major Churches............................................ 89

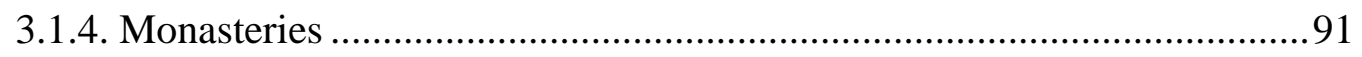

3.1.5. Relations between the Two Bishoprics .................................................. 94

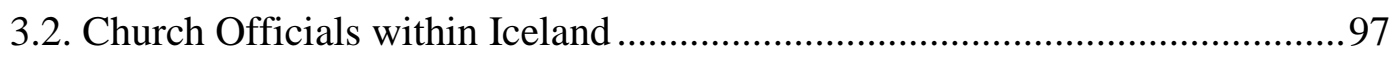

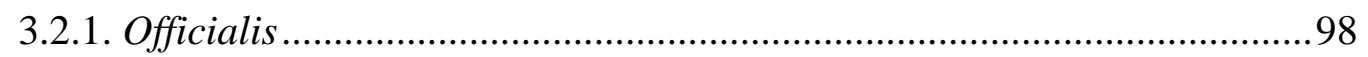

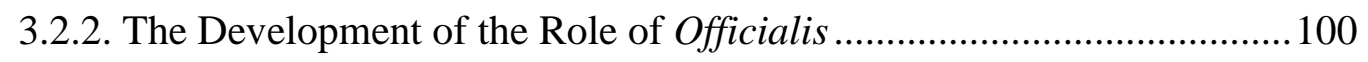

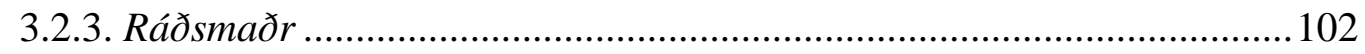

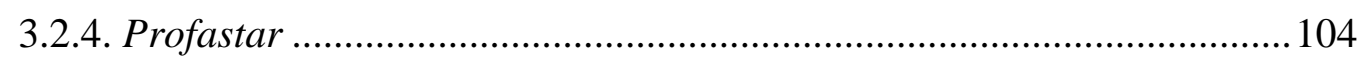

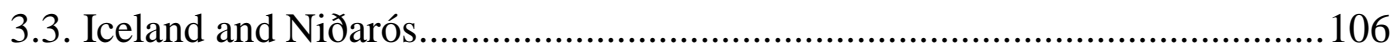

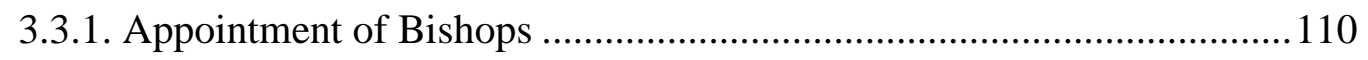

3.3.2. Norwegian Bishops ........................................................................... 113

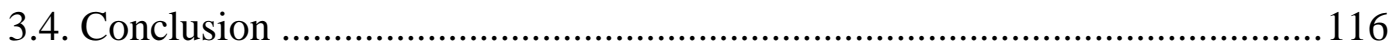

Chapter Four: Sub-Episcopal Elite Priests in Iceland ........................................... 118

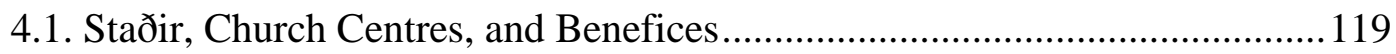

4.2. Elite Priests in Iceland during the Norwegian Age (1269-1400) ................. 122

4.2.1. The Earliest Benefice-holders, and the Establishment of Benefices...... 123

4.2.2. The Clerical Elite at the End of the Norwegian Age: A Case Study ..... 127

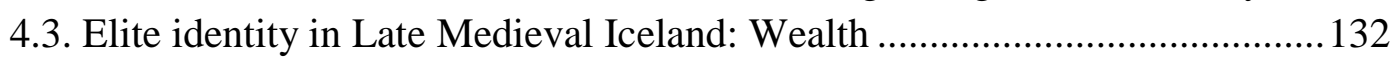

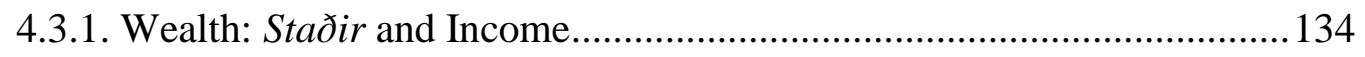

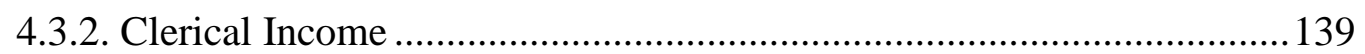

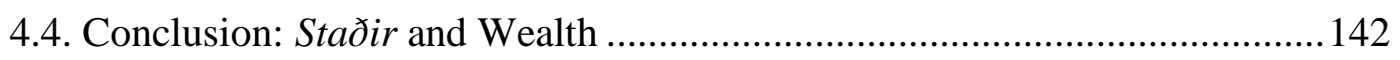

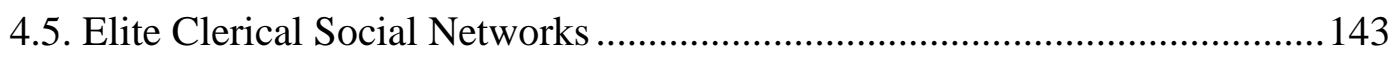

4.4.1. Relations with the Bishop: Ties of Loyalty and Friendship................... 144

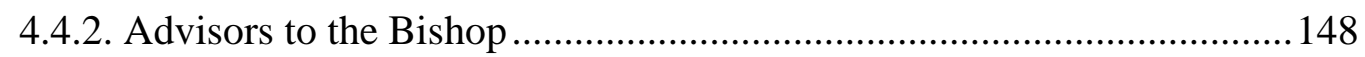

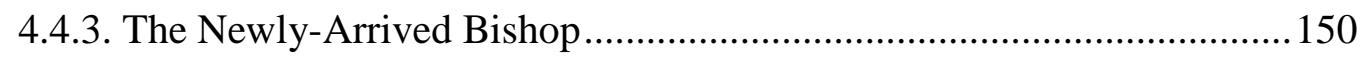

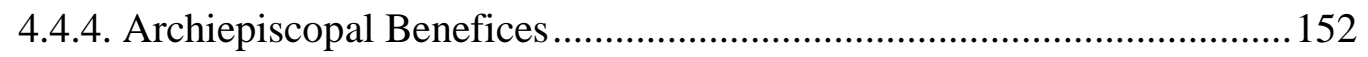

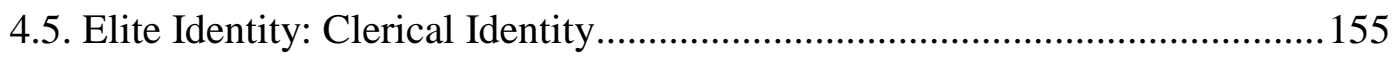

4.5.1. Clerical Concubinage, Fostering, and the Children of Clerics............... 157

4.5.2. Clerical Violence and Conflict............................................................ 163

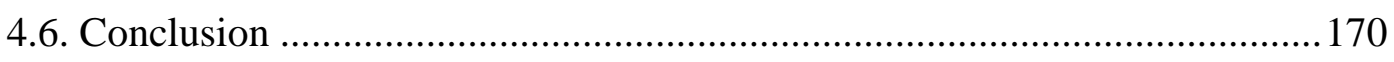

Chapter Five: Norway and Elite Icelandic Clerical Identity ................................. 172

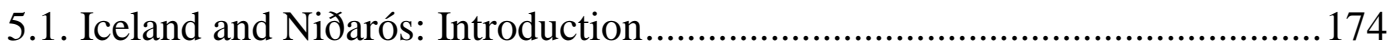


5.1.1. Relations with the Archbishop: The Growth of Centralised Authority . 174

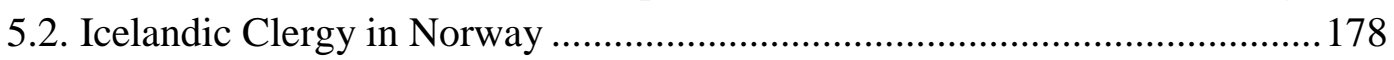

5.2.1. Icelandic and Norwegian Clerics: Problems of Terminology............... 179

5.2.2. Icelandic Clerics in Norway: The Evidence......................................... 182

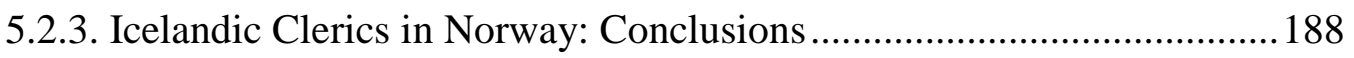

5.3. Icelandic Perceptions of Norway and Niðarós: Themes ............................... 189

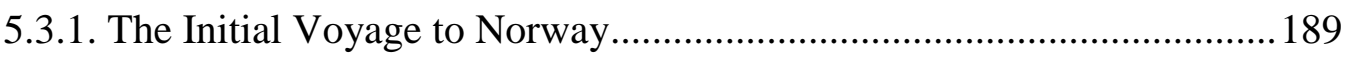

5.3.2. Two Icelandic Bishops in Norway: Finances and Other Concerns........ 196

5.3.3. Egill Eyjólfsson and Arngrímr Brandsson's Journey to Norway ........... 199

5.3.4. Iceland Perceptions of Norway and Niðarós: Conclusions ....................201

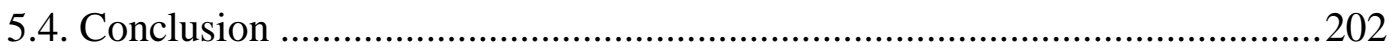

Chapter Six: Conclusion: The Sub-Episcopal Elite Priests in the Fifteenth and

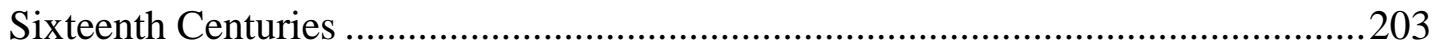

6.1. The Sub-Episcopal Elite in the Fifteenth and Sixteenth Centuries ...............204

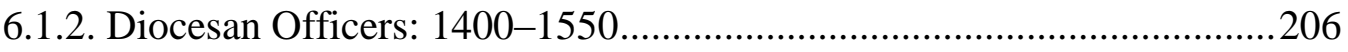

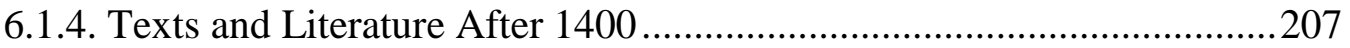

6.2. Foreign Bishops, Ecclesiastical Administration, and Narrative Sources ......210

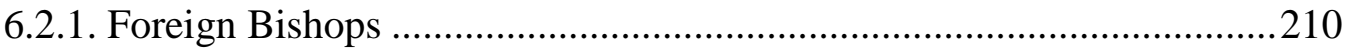

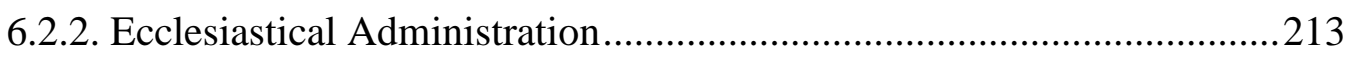

6.2.3. Narrative, Fourteenth-Century Sources, and False Accounts ...............215

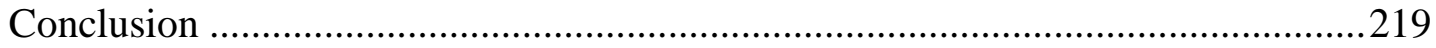

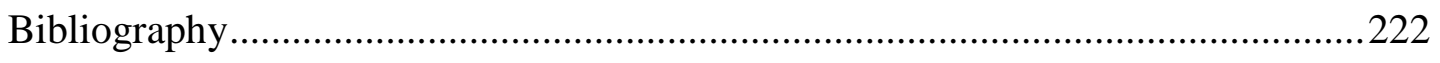

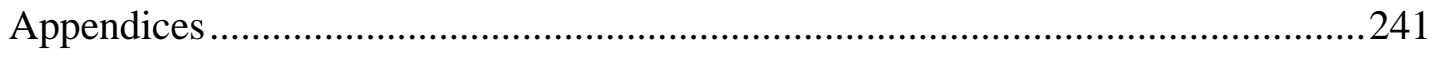

Appendix 1: Bishops of Skálholt and Hólar, 1056-1550 ..................................241

Appendix 2: The officiales and ráðsmenn of Skálholt and Hólar........................243 
Tables

1 Currency and Units of Measurement in Iceland 41

2 Major Churches in Skálholt $\quad 120$

3 Major Churches in Hólar 121

4 Clerics with children: 1380-1405 161

5 Clerics with children (Lárentíus saga) 162

6 Killings of priests (Icelandic Annals): 1300-1400 169

7 Bishops of Skálholt: 1056-1540 241

8 Bishops of Hólar: 1106-1550 242

9 Officiales of Skálholt 243

10 Ráðsmenn of Skálholt 244

11 Officiales of Hólar 245

12 Ráðsmenn of Hólar 246 


\begin{abstract}
Abbreviations
All references to the Icelandic annals (especially Skálholtsannáll, Brot af Skálholtsannáll, Lögmannsannáll, Gottskálksannáll, and Flateyjarannáll) are from Gustav Storm's 1888 edition, unless otherwise noted. All quotations from Lárentíus saga are from the A-version of the Íslenzk Fornrit edition, unless otherwise noted.
\end{abstract}

Árna saga

DI

$\mathrm{DN}$

Guðmundar saga D

ÍF

$K L N M$

Lárentíus saga
Guðrún Ása Grímsdóttir, ed., Biskupa Sögur III: Árna Saga Biskups, Lárentíus Saga Biskups, Sögupáttur Jóns Halldórssonar Biskups, Biskupa Attir, Íslenzk Fornrit, 17 (Reykjavík: Hið íslenzka fornritafélag, 1998)

Diplomatarium Islandicum: Íslenzkt fornbréfasafn

Diplomatarium Norvegicum, 22 vols (Kristiania: Malling; Oslo: Norsk Historisk Kjeldeskrift-Institutt, 1847-1976)

'Guðmundar saga Arasonar', in Biskupa Sögur, ed. by Jón Sigurðsson and Guðbrandur Vigfússon, 2 vols (Copenhagen: Hið íslenzka bókmenntafélag, 1858), II, pp. $1-187$

Íslensk Fornrit

Kulturhistorisk leksikon for nordisk middelalder fra vikingetid til reformationstid

Guðrún Ása Grímsdóttir, ed., Biskupa Sögur III: Árna Saga Biskups, Lárentíus Saga Biskups, Sögupáttur Jóns Halldórssonar Biskups, Biskupa Attir, Íslenzk Fornrit, 17 (Reykjavík: Hið íslenzka fornritafélag, 1998)

RN dokumente (Christiania: Thronsen, 1898) 


\section{Spelling Conventions and Translation}

All Icelandic names in the bibliography are alphabetised under first names. Place names are given in Modern Icelandic, with the exception of modern-day Trondheim; following medieval usage, I have used the name Trondheim to refer to the surrounding area, and Niðarós for the town, as well as the cathedral and archdiocese.

All Icelandic and Scandinavian personal names are given in standardised Old Norse, except where I have considered an individual to be better known by their anglicised name (for instance Margaret, Queen of Denmark). The personal name Lárentius (Bishop of Hólar, 1324-31) I have rendered as such, this being to my mind an acceptable compromise between the Icelandic and Latin spellings of the name. The bishops' saga by the same name, however, I have given as Lárentíus saga, this being the spelling preferred by the editor of the ÍF edition. This usage is inconsistent, but unavoidable.

By the fourteenth century, Old Norse-Icelandic had undergone sound changes which normalised Old Norse fails to reflect. Perhaps most notably, by the fourteenth century the diphthongs $Q$ and $\varnothing$ had merged with ö, while œ had merged with æ; following the normalised fourteenth-century spellings in Guðrún Ása Grímsdóttir's Íslensk Fornrit edition of fourteenth-century bishops' sagas, I have standardised accordingly. ${ }^{1}$

All translations are my own, unless otherwise noted. Original texts are provided; these have not been modified from their edited form.

\footnotetext{
${ }^{1}$ See also the normalisation used by the recent edition of fourteenth-century skaldic poetry, 'Introduction', in Skaldic Poetry of the Scandinavian Middle Ages: Poetry on Christian Subjects, 2 vols, ed. by Margaret Clunies Ross, Skaldic Poetry of the Scandinavian Middle Ages, 7 (Turnhout: Brepols, 2007), pp. 1xv-lxvii.
} 


\section{Maps}

\section{Map 1: Monasteries of Iceland}

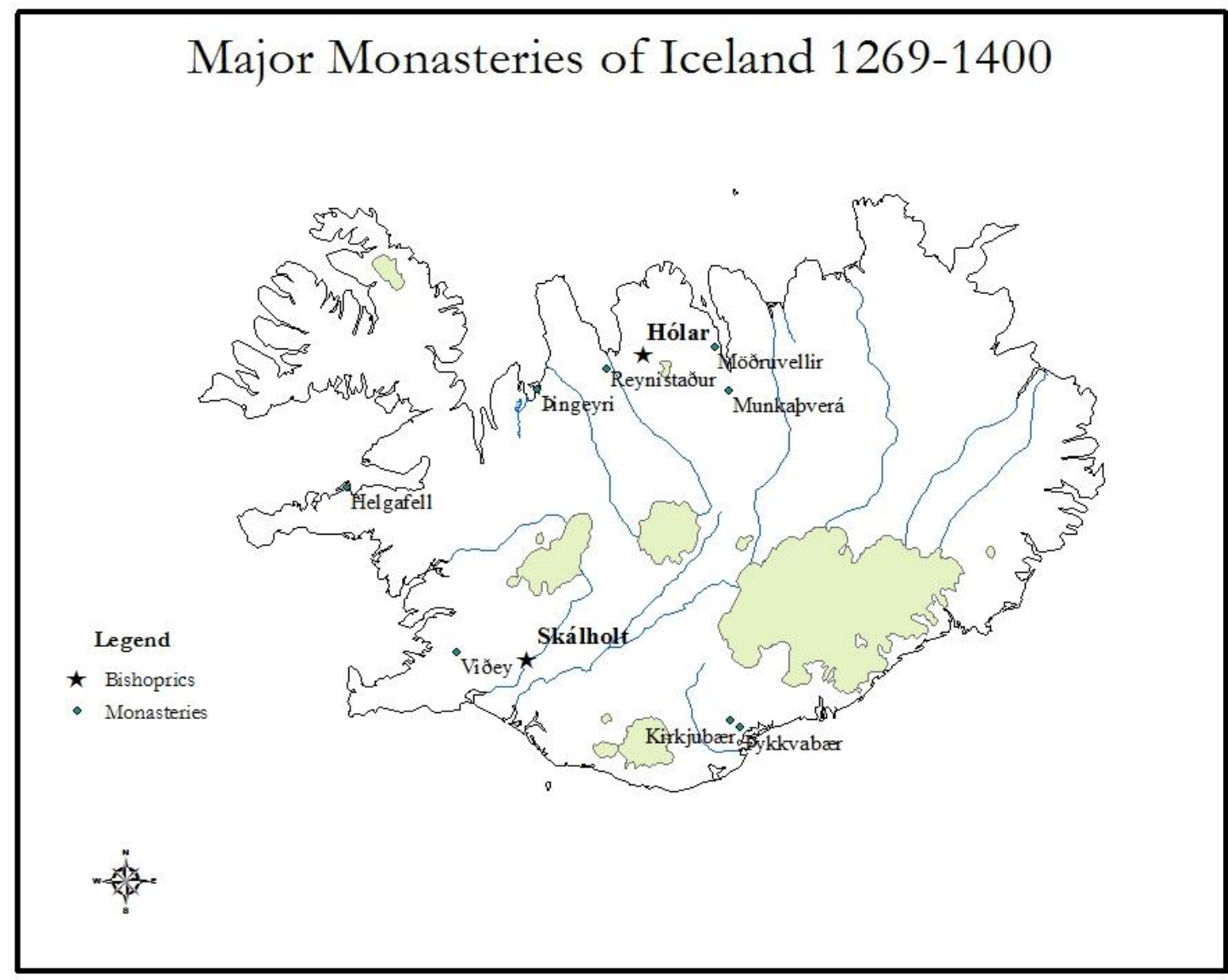


Map 2: Major Churches of Hólar

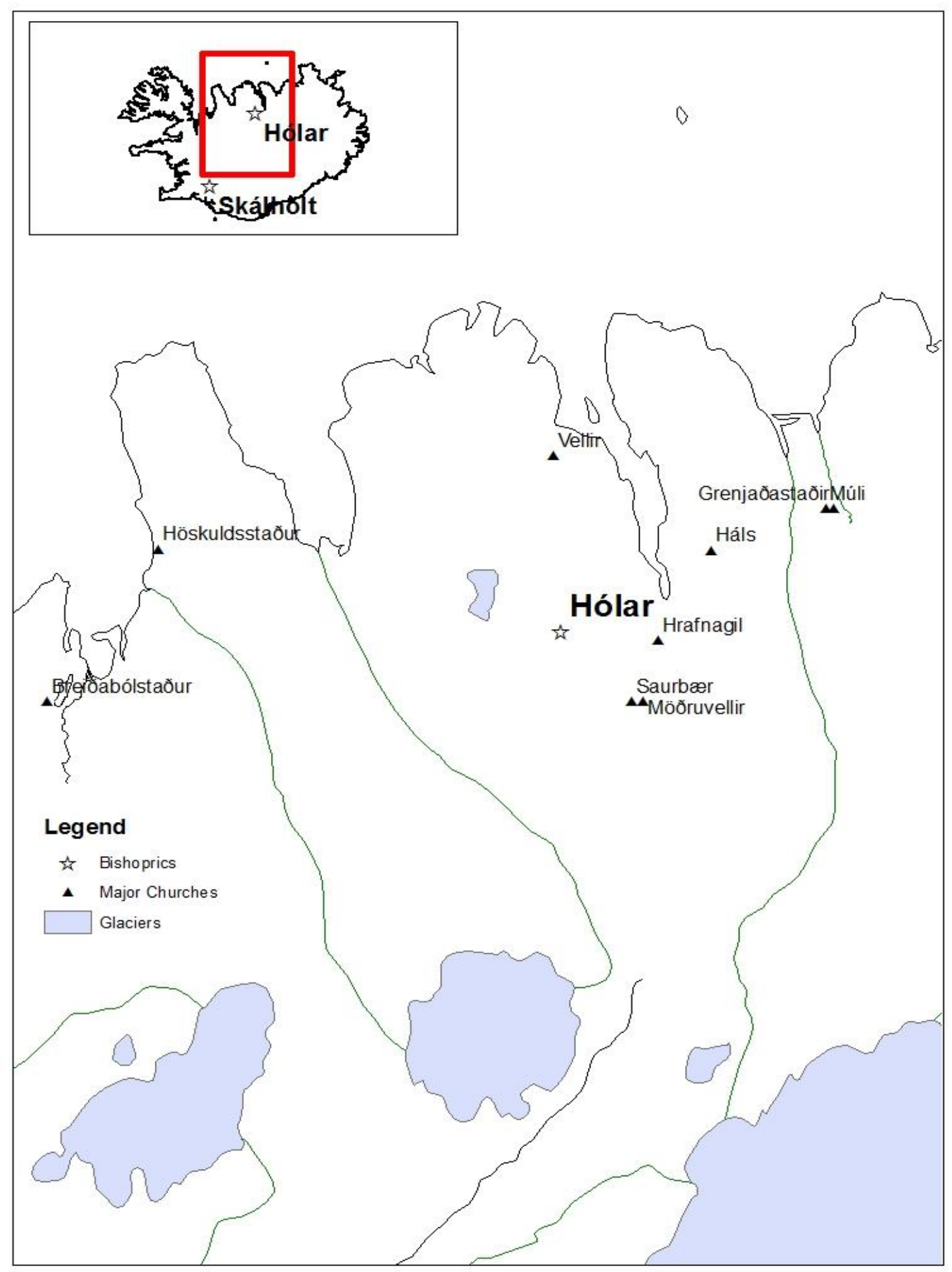


Map 3: Landholdings of Breiðabólstaður í Vesturhópi

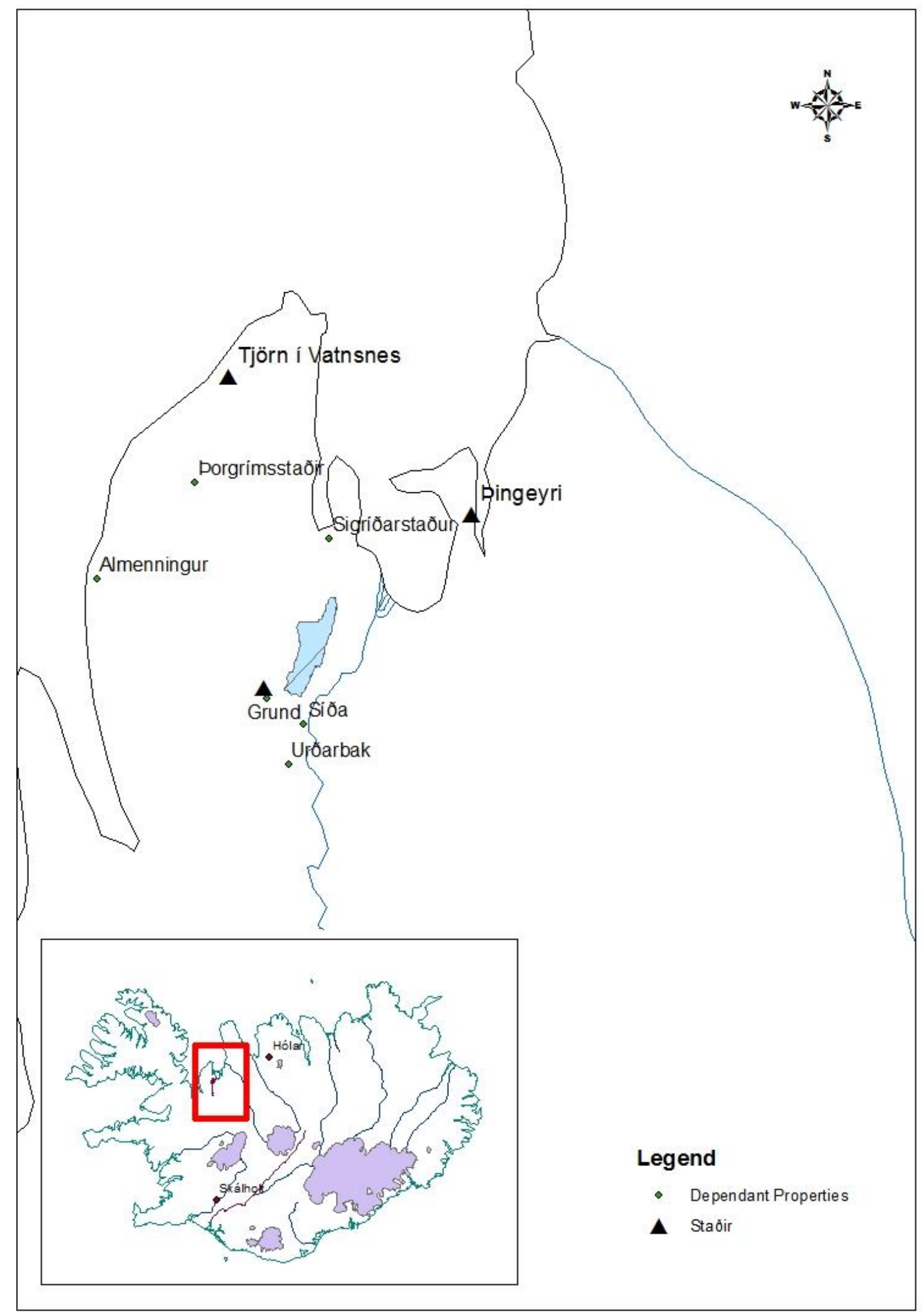




\section{Introduction}

The study of the Icelandic Church has tended to focus on the early period, of conversion and Christianisation, the earliest Christian institutions, and the development over the course of the twelfth and thirteenth centuries towards a more unified Church. What has been neglected in this approach is the study of the fourteenth century and later. In fact, the fourteenth century has been relatively neglected in studies of Icelandic history generally, which overwhelmingly prefer the period before Iceland's submission to Norway in 1262-64. In what follows, therefore, I provide a detailed study of Icelandic clergy and the institutions of the Icelandic Church in the period from 1300 to 1404.

There is, in fact, a great deal of literary evidence for the importance of Church and religion in the fourteenth century. It was in this period that literature turned to religious subjects to a degree not seen before, with bishops' sagas, translated saints' lives, Christian skaldic poetry and more. While this literary production was once neglected by a scholarly community interested primarily in secular or pre-Christian literature (despite the frequent survival of this literature in fourteenth-century manuscripts), it has been studied more widely in recent years. A number of new editions of religious sagas have been published and the new Skaldic Poetry Project includes, for the first time, the vast and neglected field of religious poetry. Although the study of fourteenth-century literature remains a nascent field, the value of this later body of literature, which combines native Icelandic traditions with wider European learning, Norse and Latin literary styles, has begun to be appreciated and studied.

What continues to be neglected in this new appreciation for the religious literature and manuscript production of the fourteenth century are the institutional and social developments within the Icelandic Church in this period. To date, no study has taken the structures of the Icelandic Church, or the social and cultural makeup of the Icelandic clergy, after the reforms of the thirteenth century as its focus. Moreover, while a few scholars have attempted to make use of the bishops' sagas and other forms of religious literature to analyse fourteenth-century society, no scholarship has yet made use of the emerging genres of annalistic writing and bureaucratic writing (documents) to place this religious writing in the context of new 
developments in writing culture, or the socio-political developments of the elite beneficed clergy in fourteenth-century Iceland. While literary and philological studies have begun the project of studying fourteenth-century religious literature, much remains too to be done in this field. In particular, historical research has yet to be undertaken with the aim of contributing to our current understanding of the literary production of this period through comprehensive study of the social, cultural, and intellectual milieu in which this literature was produced. It is this gap that I fill with the following study.

In addition to developments in religious writing, the fourteenth century introduced major changes to the complexity of ecclesiastical administration, as well as to the social and economic makeup of the elite clergy. While scholarship has assumed that in the late Middle Ages the Icelandic Church became more centralised, more structured, and vastly wealthier than it had been in previous centuries, to date there has been no detailed study to examine these assumptions in detail. As I will show, these generalisations are partially accurate; there is marked evidence of the increase in wealth both of the Church as an institution, and of individual members of the clergy, for instance. Moreover, the development of bureaucratic writing in the mid-fourteenth century can indeed be connected to greater institutionalisation and more complex structures; although in my opinion the levels of institutionalisation in the fourteenth-century Icelandic Church have been dramatically overstated. At the same time, however, these generalisations underestimate the complexity of the late medieval Church, in both its close integration into the structures and doctrines of the Universal Church, and its adoption and integration of older Icelandic social structures.

As Magnús Stefánsson has clearly articulated, ecclesiastical reforms of the late thirteenth century created a beneficial system in Iceland. ${ }^{1}$ Where previous research on this reform has either emphasised the powers which accrued to the Church through the gain of church property, or debated the consequences of this loss to the Icelandic secular aristocracy, I focus instead on the results of this development for the privileged clerics who for the first time received large farms, called staðir, as benefices. I trace the growth of this close-knit group of clerics over the course of the

1 Magnús Stefansson, Staðir og staðamál: Studier $i$ islandske egenkirkelige og beneficialrettslige forhold (Bergen: Universitetet i Bergen, Historisk institutt, 2000), p. 48 et passim. 
next century. In addition to describing the economic basis for the development of this group, with a focus on the economic and social value of the staðir to their holders, I also discuss the social structures of the emerging clerical elite. In this discussion, I focus in particular on connections, networks, and relationships of mutual obligation, particularly between the elite clergy and their direct superiors, the bishops.

One of the most controversial aspects of the fourteenth-century Church in Iceland is the strong orientation of the Icelandic Church towards Norway, and its metropolitan in Niðarós. After Iceland's subjugation to the Norwegian Crown in 1262-64, Norway became the dominant force in Icelandic politics and trade until the fifteenth century, when it was replaced politically by Denmark and in the economic sphere by the influx of English merchants and English trade. In the ecclesiastical sphere, however, Norwegian influence had even deeper roots. There were a number of political factors involved in the creation of the church province of Niðarós, in modern-day Trondheim, in 1152 or 1153, but probably the most relevant for Iceland was the desire to bring the islands of the North Atlantic more directly into the sphere of influence of the Norwegian Church, a policy in line with Gregorian interest in bringing the periphery of Europe more closely under the control of the papacy. Although archiepiscopal policies towards Iceland were not consistently applied from the twelfth to the fourteenth centuries, their general tendency was always in line with the principal of archiepiscopal authority over the North Atlantic dioceses.

Past work on Iceland and Norway has tended to be drawn along national and sometimes nationalist lines, although recent work on the Icelandic Church has tended instead to emphasise Icelandic integration into the so-called 'Universal Church'. Additionally, the study of the Church in Iceland has tended to focus on institutional and structural developments rather than on individuals and local communities. This thesis shows that this has limited our appreciation of the real workings of the fourteenth-century Church. In what follows, I discuss Iceland's relationship to Norway instead through a study of individual agents. In this way, I am able to address not only economic and political dependence after 1262-64, but also elements of cultural identity and Icelandic identification with Norway as a parent country; as well as the roles of social networks in institutional structures and practices. While these and similar issues have been addressed by previous scholarship, particularly in 
relation to Icelandic literary production, they have not yet been integrated into the wider history of the Icelandic Church in the later Middle Ages.

The study of the fourteenth century to date has looked different from earlier periods because new sources, primarily the documentary record, had become available and historians in particular have been interested in using documentary material instead of narratives. At the same time, fourteenth-century narratives are also available; these need to be used to create a fuller picture of the past. In what follows, I have attempted to integrate the study of narrative and non-narrative sources. This project of studying both narrative and non-narrative sources in turn will allow scholars new ways in which to assess the nature and meaning of Icelandic narratives for earlier periods, which share many of the features of late medieval Icelandic narrative sources. Finally, the study of fourteenth-century narrative sources may also provide access to changing understandings and awarenesses among fourteenth-century writers of how history writing was produced, and why. Fourteenth century history writing included new, learned elements such as annals and a new Latinate style alongside very traditional stylistic features of the Icelandic saga; this in turn was combined with fantastic exempla and adventure stories which drew on and connected with the other major innovation of the fourteenth century, namely the development of the Icelandic romance (riddarasögur). It is the comingtogether of so many different methods of writing and recording the past which makes the written production and intellectual milieu of fourteenth-century clerical writers so remarkable and so rewarding of study. The re-evaluation of fourteenth-century source material and its role in assessing the nature and meaning of Icelandic sources is a substantial project, and one which goes far beyond a single doctoral thesis; in what follows, I have only begun to address the many interconnected aspects of the fourteenth-century textual community.

\section{Methodology and Approaches}

In this thesis, I use a combination of prosopographical research, primarily presented through case-studies (although I also demonstrate the reach and limitations of this kind of research by presenting a selection of data in tabular form), and close reading of narrative sources (primarily Lárentíus saga, but also annals and other bishops' 
sagas). Through this mixed-method approach, I am able to explore different aspects of elite clerical identity, in particular the differences in perspective created by different kinds of source material. This kind of study is possible because, as I will show, these different kinds of text, although produced for very different purposes, were created by and large by a very small, closely-integrated group of elite clerical writers; a group which overlapped significantly with the ecclesiastical administrators, and elite beneficed clergy of fourteenth-century Iceland. Thus, while making use of a wide range of sources, I am studying a single, tightly-knit group, with an increasingly consistent sense of shared identity.

In Chapter 3, I present a study of the structures of the Icelandic Church, while in Chapters 4 and 5 I explore different aspects of elite clerical identity in realms such as participation in the economic structures of the new Icelandic aristocracy, the social hierarchies of mutual obligation and friendship within the Icelandic Church, and Icelandic perceptions of Norway and the Norwegian Church. Throughout this study, I will attempt to portray the history of institutions as the history of individual agents. The institutions of the Church were constituted by a regionally specific social network; and local networks of clerics used institutional structures for their own local and personal purposes. Understood as such, this thesis is not just about the structure of the Church but is also an exercise in sociological research benefiting from and contributing to recent work on social network theory, particularly as applied to the study of history by scholars such as Robert Jütte and John Bossy. ${ }^{2}$ The study of social networks has long been of importance to the study of medieval Iceland, but has primarily been confined to studies of familial ties, most notably in the context of feud and personal honour in the Íslendingasögur, and of the vertical ties between the chieftains (goðar) and their followers among the farmers (bandur), as well as the closely related concepts of fosterage and friendship within the context of feud and honour. ${ }^{3}$ In an influential study, Orri Vésteinsson extended this

\footnotetext{
${ }^{2}$ Robert Jütte, Poverty and Deviance in Early Modern Europe (Cambridge: Cambridge University Press, 1994); Christianity and Community in the West: Essays for John Bossy, ed. by Simon Ditchfield, (Aldersholt: Ashgate, 2001); for a study of social networks in the Icelandic context, see especially Gísli Ágúst Gunnlaugsson and Loftur Guttormsson, 'Cementing Alliances?: Witnesses to Marriage and Baptism in Early Nineteenth-century Iceland', The History of the Family, 5 (2000), 259-272.

${ }^{3}$ William Ian Miller, Bloodtaking and Peacemaking: Feud, Law and Society in Saga Iceland (Chicago, IL: University of Chicago Press, 1990); see also Jesse Byock, Medieval Iceland: Society, Sagas, and Power (Berkeley, CA: University of California Press, 1988); Jón Viðar
} 
understanding of the structure of Icelandic society, arguing that through the process of Christianisation, the clergy developed a sense of clerical identity, thus weakening their ties to family politics and placing their first allegiance to the Church. ${ }^{4}$ To date, however, no comprehensive study has been undertaken of social ties in medieval Iceland outside of the secular sphere. This project seeks to expand on this understanding of social connections in Iceland through the study of clerical social networks; as I argue below, it was the personal connections between priests, bishops, and the clerical elite in both Iceland and Norway which made up the Icelandic Church, as ecclesiastical institutions, diocesan administration, and clerical literature were moulded to the individual requirements of the beneficed elite clergy.

Sigurðsson, 'Friendship in the Icelandic Commonwealth', in From Sagas to Society: Comparative Approaches to Early Iceland, ed. by Gísli Pálsson (London: Hiserlik, 1992), pp. 205-215.

${ }^{4}$ Orri Vésteinsson, The Christianization of Iceland: Priests, Power and Social Change 10001300 (Oxford: Oxford University Press, 2000). 


\section{Chapter One}

\section{Iceland in the Fourteenth Century}

The late thirteenth century was a time of major social and political changes in Iceland. During 1262-64, Icelanders submitted to the king of Norway, ending over three centuries of local governance. Over the course of the next few decades, the Norwegian crown instituted substantial changes in Icelandic law and governance, introducing new law codes and new officials. The Church, with the support of the Norwegian crown, introduced large-scale reforms of property ownership, ecclesiastical law, and the priesthood.

It remains a matter for debate how far these changes affected Icelandic society. On the one hand, they cannot have failed to have made an impact; taxes were imposed for the first time, capital and corporal punishment were introduced, and the goðar, or chieftains, of Commonwealth Iceland were abolished. At the same time, changes of this nature - constitutional change, new legal codes, changes to the structure of government and Church - are of a nature to create deep-rooted social changes only over long periods of time. Debate on fourteenth-century topics, however, has been slow to get going. ${ }^{1}$ Historiographical interest in the late thirteenth century has rested firmly in a retrospective view, seeking to identify 'the factors which contributed to the disintegration and demise' of the Icelandic Commonwealth. $^{2}$ Even the latest generation of scholars, less rooted in Icelandic nationalism, has tended to follow this model, taking the period before 1262 as their default period of interest. Thus, scholarly discussions of Iceland's submission to the King of Norway, even while rejecting the model of the 'fall of the Commonwealth', have tended to see this event as an end-point. ${ }^{3}$ As a result, while a great deal has

\footnotetext{
1 Notable exceptions include Agnes Arnórsdóttir, Property and Virginity: The Christianization of Marriage in Medieval Iceland 1200-1600 (Aarhus: Aarhus Universitetsforlag, 2010); Patricia Boulhosa, Icelanders and the Kings of Norway: Mediaeval Sagas and Legal Texts, Northern World, 17 (Leiden: Brill, 2005); and Lára Magnúsardóttir, Bannfaring og kirkjuvald á Íslandi 1275-1550: Lög og rannsóknarforsendur (Reykjavík: Háskólaútgáfan, 2007).

${ }^{2}$ Orri Vésteinsson, The Christianization of Iceland, p. 5.

${ }^{3}$ For a clear example of this, see Orri Vésteinsson's The Christianization of Iceland. While Orri beings with a strong critique of nationalist historiography (pp. 4-5), his narrative arc remains that of the Commonwealth era, and he ends his study of the development of clerical
} 
been written about the development, disintegration, and growth of social complexity, and internal crises leading up to the changes of the third quarter of the thirteenth century, hardly any attention has been paid to the effects of this change on Icelandic society, in both historical and literary study. ${ }^{4}$

What follows is an introduction to the historical study of Iceland in the fourteenth century, with a focus on legal and administrative changes, the changing nature of the aristocracy and relations to the Norwegian Crown, and on the ecclesiastical reforms of the late thirteenth century. The fourteenth century has yet to be studied in the same detail as the centuries which preceded it, and where relevant, I have highlighted areas for future research.

\subsection{Sources and Historiography}

In this survey of Icelandic history after 1264, I discuss the role of modern Icelandic nationalism, perhaps one of the most ubiquitous features of modern Icelandic historiography. Icelandic scholars, influenced by nationalist concerns over independence and subjugation, have strongly emphasised the project of describing and analysing the government and society of the Commonwealth period, and tracing the factors of its decline and fall. In this framework, the period after 1264 has functioned rhetorically as a period of decay and stagnation, in which Icelanders languished under foreign rule.

This is not the place to discuss at length the role of modern nationalism in the current scholarly neglect of the late Middle Ages in Iceland, and indeed, Icelandic nationalism and nationalist thought have been discussed so often in recent years that it feels a bit redundant to claim that nationalism has affected the writing of history in Iceland. I do, however, want to dwell a little on the relationship between nationalism and saga-writing or written culture, because it is this aspect of nationalist thought which has the most relevance to my current project. Here too, I am saying nothing new by claiming that Icelandic nationalist sentiment has been tied to books and

identity with the end of the Commonwealth, or a few years after; see especially p. 16. For further discussion, see below, section 1.6.

${ }^{4}$ On the neglect of later medieval literature, see Matthew Driscoll, 'Late Prose Fiction (lygisögur)', in A Companion to Old Norse-Icelandic Literature and Culture, ed. by Rory McTurk (Oxford: Blackwell, 2005), pp. 190-204 (especially pp. 196-97). 
literature, and especially to the Íslendingasögur, the sagas of Icelanders. ${ }^{5}$ Indeed, one of the most pervasive assumptions about the fourteenth century and the periods after it is that sources from and about this period are boring, insufficient, or non-existent. However, such assumptions are rarely made explicit, and exist only in the underlying apparatus of history writing. Hayden White explains the importance of narrative in the production of history when he writes:

Every historical discourse contains within it a full-blown, if only implicit, philosophy of history [...] The principal difference between history and philosophy of history is that the latter brings the conceptual apparatus by which the facts are ordered in the discourse to the surface of the text, while history proper (as it is called) buries it in the interior of the narrative, where it serves as a hidden or implicit shaping device. ${ }^{6}$

In Icelandic history, negative assumptions about the fourteenth century can be found primarily in two places: in histories that frame the years 1264 to 1300 as an endpoint, the culmination of medieval Icelandic achievement or as the 'fall of the Icelandic Commonwealth', and in discussions of sources and literature. Here, I want to highlight the way that negative assumptions about the fourteenth century can be found in discussions of sources and literature in the late Middle Ages. I focus specifically on the way it plays out in passages from two notable works of scholarship, namely Gunnar Karlsson's Iceland's 1100 Years, and Orri Vésteinsson's The Christianization of Iceland, two relatively recent, popular, and influential works of history. What stands out in both of these passages is close intertwining of two concepts: a conceptualising of the 'fall of the Commonwealth' as loss, and the perceived deficiency of sources in post-Commonwealth Iceland. At the end of a section on the end of the Icelandic Commonwealth, Gunnar Karlsson concludes:

\footnotetext{
${ }^{5}$ On the role of nationalism in the development of the thought of Sigurður Nordal and the bookprosist school, see Jesse Byock, 'Modern Nationalism and the Medieval Sagas', in Northern Antiquity: The Post-Medieval Reception of Edda and Saga, ed. by Andrew Wawn (London: Hisarlik Press, 1994), pp. 163-87. Important criticism of this view of Icelandic literature has been put forward by scholars of riddarasögur (late medieval Icelandic romance) and a good summary of the bookprosist view of Icelandic literary history, with a focus on the riddarasögur, can be found in Matthew Driscoll, 'Late Prose Fiction', especially pp. 196-98; see also Matthew Driscoll, 'Pögnin mika: Hugleiðingar um riddarasögur og stöðu peirra í íslenskum bókmenntum', Skáldskaparmál, 1 (1990), 157-68.

${ }^{6}$ Hayden White, Tropics of Discourse: Essays in Cultural Criticism (Baltimore, MD: Johns Hopkins University Press, 1978), p. 127.
} 
So the Commonwealth was abolished, and European culture lost one of its small varieties. It is of course safest not to make too many assertions about the social consequences of this change. In the modern context, however, it sounds as if Iceland was silenced by it. We hear of no major warfare in the country after this, and no contemporary sagas describe the acts of its secular aristocracy. Two bishops' sagas and a few brief annals are the only narrative sources about the following centuries. Family sagas which are thought to have been written in the 14th century are much less to our taste and are less informative about social norms and attitudes than those attributed to the 13th century [...] Yet, while it is safest not to make too many assertions it ought to be permissible to think that Icelandic culture lost something valuable when the Norwegian Crown relieved it of the challenge of maintaining law and order in the country without a pyramidal system of government. ${ }^{7}$

Gunnar Karlsson has highlighted here the loss of Iceland's system of government, one of the 'unique' features of Icelandic society as one of the losses associated with the abolishment of the Commonwealth. The loss of Iceland's unique identity is described in this passage ('European culture lost one of its small varieties'), together with the loss of independence ("when the Norwegian Crown relieved it of the challenge of maintaining law and order'). Linked in this passage to the loss of independence and the loss of Icelandic uniqueness, is the alleged poverty of fourteenth-century sources. Gunnar's brief survey of fourteenth-century source material is entirely negative: there are, he regrets, 'no accounts of warfare, and no sagas describing the secular aristocracy [my italics]'; 'only' two bishops' sagas and 'a few brief annals' exist as narrative sources for the period. Gunnar here is not simply neutrally outlining the limitations of fourteenth-century source material; his tone is dismissive and the unstated assumption is that the sources are so poor that the fourteenth century is unknowable. This conclusion is reinforced by his assertion that 'Iceland was silenced by it [the loss of independence]', and his repeated caveat that it is 'safer not to make too many assumptions' about the fourteenth century. The general conclusion is that there are in fact no sources about the fourteenth century, or that there are so few as to be utterly unhelpful.

Gunnar's final swipe at fourteenth-century source material is his claim that, fourteenth-century family sagas are, 'much less to our taste and are less informative about social norms and attitudes than those attributed to the 13th century'. In this assessment, he appears to be following Vésteinn Ólason's views on fourteenth-

${ }^{7}$ Gunnar Karlsson, Iceland's 1100 Years: The History of a Marginal Society (London: Hurst, 2000), p. 86. 
century family sagas. ${ }^{8}$ Vésteinn has argued that the fourteenth-century sagas, in contrast to earlier sagas, contained strong elements of fantasy and adventure, and drew more heavily on universal wonder-tales, and Christian exempla; they became 'simply tales of adventure'. ${ }^{9}$ This approach fits closely with Sigurður Nordal's view of thirteenth-century Íslendingasögur as the height of medieval Icelandic literature, with the quality of literature declining as society fell into decay in the fourteenth century and later. ${ }^{10}$ However, this approach also ignores the ways in which fantasy, adventure, and the extended use of foreign genres or international motifs can also be highly informative about the society which produced them, as has been shown by scholars studying the riddarasögur, translated saints' lives, and other fantastic or imported genres. ${ }^{11}$ It is particularly strange that Gunnar Karlsson, a historian interested in the Íslendingasögur primarily for their historical, and not for their aesthetic value, would dismiss the fourteenth-century Íslendingasögur as much for being 'not to our taste' as for failing to reflect the social norms and attitudes of the time of their writing. However, it reflects the same rhetoric of decline and decay, and the connection between social and literary decline articulated by Sigurður Nordal and his school.

In The Christianization of Iceland, Orri Vésteinsson employs very similar rhetoric, and presents a strikingly similar picture of fourteenth-century Icelandic society and the sources which it produced. In this passage, being indistinguishable from the rest of Europe is framed as a loss, and linked with the (supposed) failings of the documentary record:

Any student of late medieval Europe would have little difficulty in recognizing the administration and judicial system of fourteenth-century Icelandic society. Apart from the economic base [...] Icelandic society was structured much like any other poor, remote, and isolated part of a European kingdom [...] The documents this society

${ }^{8}$ Vésteinn Ólason, Dialogues with the Viking Age: Narration and Representation in the Sagas of the Icelanders, trans. by Andrew Wawn (Reykjavík: Mál og Menning, 1998). See also his more recent article, 'The Fantastic Element in Fourteenth-Century Íslendingasögur', Gripla, 18 (2007), 7-22.

${ }^{9}$ Vésteinn Ólason Dialogues with the Viking Age, pp. 180-90, especially p. 190.

${ }^{10}$ See Driscoll's summary in 'Late Prose Fiction', pp. 196-97.

${ }^{11}$ See especially Jürg Glauser, Isländische Märchensagas: Studien zur Prosaliteratur im spätmittelalterlichen Island, Beiträge zur nordischen Philologie, 12 (Basel: Helbing \& Lichtenhahn, 1983); Marianne Kalinke, The Book of Reykjahólar: The Last of the Great Medieval Legendaries (Toronto, ON: University of Toronto Press, 1996); and Elizabeth Ashman Rowe, The Development of Flateyjarbók: Iceland and the Norwegian Dynastic Crisis of 1389 (Odense: University Press of Southern Denmark, 2005). 
produced about itself were of the dull sort; deeds of property transfer, church-charters, marriage contracts, and wills. Together with the annals, the writing of which was waning in the fourteenth century, these documents are the principal sources for Icelandic society in the late middle ages. They differed from comparable documents from the same period in Europe only in that they were written in the vernacular. ${ }^{12}$

The rhetoric of decay and decline in the second passage is made even stronger by a contrasting picture of a vigorous and exciting twelfth- and thirteenth-century Iceland, one with 'no administration, no centralized authority, and a church dominated by secular interests', and saga-writing. ${ }^{13}$ As in the previous passage, a significant critique of fourteenth-century written sources is entirely aesthetic: fourteenth-century documents are 'of the dull sort'. This is an even odder critique for a historian to make of documentary sources than of saga material; wills and land transfers are rarely praised for their entertainment value. ${ }^{14}$

In this passage, more explicitly than in the previous one, foreign influence on the written sources is highlighted as a reason for their dullness: Icelandic documents 'differed from comparable documents from the same period in Europe only in that they were written in the vernacular'. ${ }^{15}$ Orri's listing of the types of documents which he considers dull serves further to reinforce the association between European influence and decline: deeds of property transfer, church-charters, marriage contracts, and wills are all forms of writing which can be found anywhere in Europe, unlike the saga, which in the formulation of Sigurður Nordal and the bookprosist school was a uniquely Icelandic creation. ${ }^{16}$

The claim that Icelandic administrative writing was indistinguishable from the rest of Europe is for start only partially accurate; there are certainly parallels between Icelandic vernacular bureaucratic writing and the tradition of administrative writing elsewhere in Europe, but the similarities are not so immediately striking as this passage would suggest. To take a basic, but significant example, some scholars argue that Icelandic and Norwegian bureaucratic writing took as its foundation Icelandic and Norwegian law and legal ritual, adding a 'superstructure' of written

\footnotetext{
${ }^{12}$ Orri Vésteinsson, The Christianization of Iceland, p. 1.

${ }^{13}$ Ibid., p. 1.

${ }^{14}$ Orri Vésteinsson does not now identify as a historian, but rather as an archaeologist; The Christianization of Iceland is however, a work of history and thus for the purpose of this discussion, Orri Vésteinsson will be referred to as a historian, or producer of history. See Keith Jenkins, Re-thinking History, 2nd ed. (London: Routledge, 2004).

${ }^{15}$ Orri Vésteinsson, The Christianization of Iceland, p. 1.

${ }^{16}$ Jesse Byock, 'Modern Nationalism', pp. 165-69.
} 
documentation to the oral legal rituals previously in place. ${ }^{17}$ There is certainly room to debate this interpretation of Icelandic bureaucratic writing; it does not, for instance, adequately explain the deliberate use of Latinate forms and the careful translation of Latin formulas in Icelandic administrative documents. Such criticism will however, only complicate and enrich our understanding of Icelandic bureaucratic writing, and is in no way proof of the 'dullness' or lack of value of late medieval Icelandic diplomatic writing. The rhetoric of the passage quoted above however, does not allow for any nuance in the concept of European influence, or in the fourteenth century. Icelandic society in the fourteenth century, in contrast to earlier periods, was 'much like any other poor, remote, isolated part of a European kingdom', and therefore not worthy of study. ${ }^{18}$

Here, as in the previous passage, the rhetoric is intended to convey the effect that there is nothing worth studying about the fourteenth century. Orri claims that 'any student' would have 'little difficulty' in recognising the administrative and judicial structures of late medieval Iceland, implying that the project of studying these structures is simplistic and without merit. Moreover, he claims that the documents which form the principal source material for this period are boring, while annal-writing was 'waning'; the implication of this assessment of fourteenth-century source material is that there is nothing to reward attempts to study this bleak period. This implication is false, but it reflects again the long-held belief in the decline of Icelandic society after the loss of independence and with the arrival of European influence.

Before leaving this discussion, I want to be clear about the relation of these two passages to the texts from which they are taken. Neither passage is central to any main argument; the passage from Orri Vésteinsson's The Christianization of Iceland is taken from the opening paragraph of the book, while the passage from Gunnar Karlsson's Iceland's 1100 Years is taken from a concluding paragraph, wrapping up a chapter, and indeed, an entire section. I am thus focusing closely on two passages which are intended only to function rhetorically; to set the tone for what follows, or

\footnotetext{
${ }^{17}$ Hallvard Magerøy, 'Diplomatics', in Medieval Scandinavia: An Encyclopedia, ed. by Philip Pulsiano and Kirsten Wolf (London: Garland, 1993), pp. 137-38 (p. 137). See also Arnved Nedkvitne, The Social Consequences of Literacy in Medieval Scandinavia, Utrecht Studies in Medieval Literacy, 11 (Turnhout: Brepols, 2004), p. 95. For further discussion of Icelandic documentary sources and their production, see Chapter 2.5.

${ }^{18}$ Orri Vésteinsson, The Christianization of Iceland, p. 1.
} 
to mark the passage from one section to another. It is not my intention to take these passages out of context to criticise the value of these two texts as a whole (on the contrary, it will be evident from my footnotes how useful these studies are). Rather, it is in the unguarded writing of opening paragraphs and concluding remarks that underlying assumptions come out most clearly; moreover, the peripherality of the fourteenth century in both these works is reflective of the field more generally.

Not all historians have followed the implied advice of Gunnar Karlsson and Orri Vésteinsson and avoided the study of the fourteenth century and its boring and unsatisfactory sources. On the contrary, there is a growing number in the latest generation of historians looking to the fourteenth century, and making use of documentary sources, annals, and other late medieval source material, as I describe in the remainder of this chapter. However, historians within this field have not yet directly addressed the bookprosist model of late medieval decline, and the complex role that source criticism has played in developing and maintaining negative preconceptions about the late Middle Ages. Additionally, there has been insufficient dialogue between the fields of late medieval Icelandic history in particular and saga studies, or literary criticism. Historians studying this period have for the most part taken an empirical approach to its study, making use of documentary evidence, annals, and laws (including canon law), while avoiding sources and themes relating to issues such as fictionality, narrative and its role in the construction of the past. ${ }^{19}$

This reluctance within the field of late medieval history to address directly the bookprosists' model of late medieval decline is all the more regrettable for the fact that historical methods could provide a set of highly effective methodologies for dismantling assumptions which tie the perceived disintegration of Icelandic society so closely to the perceived decline of 'classical' saga writing, and literary production more generally. ${ }^{20}$ Historical approaches can be less closely tied to narrative sources,

\footnotetext{
${ }^{19}$ Here I am thinking in particular of recent works such as Agnes Arnórsdóttir, Property and Virginity; and Lára Magnúsardóttir, Bannfaring og kirkjuvald. Helgi Porláksson describes a similar interest in the reliable nature of fourteenth- and fifteenth-century source material in early Icelandic history writing in 'Sagnfræði um Íslandssögu á tímabilinu 1300-1550', Saga, 38 (2000), 59-81 (especially pp. 66-67).

${ }^{20}$ For fairly straightforward descriptions of historical method see for example, John Tosh, The Pursuit of The Pursuit of History: Aims, Methods and New Directions in the Study of Modern History, 3d ed. (Harlow: Longman, 2000). For a more nuanced exploration of the discipline of history in the context of postmodern thought, see the now-classic Keith Jenkins, Rethinking History, 2nd ed. (London: Routledge, 2003), and Gabrielle Spiegel, The Past as
} 
prioritising instead data from multiple sources, and data from sources regardless of aesthetic value. While historical method has been criticised for its 'fetishization' of the document, prioritising documentary evidence to the point of excluding all others, more recent approaches to the study of history have emphasised instead the possibilities for using a wide range of narrative and non-narrative sources. ${ }^{21}$ Crucially, historical method provides a framework for the study of Icelandic history outside of the pairing of 'literature and culture', which has long been dominant in the field of Old Norse-Icelandic Studies. This can only be accomplished, however, by historians of fourteenth-century Iceland tackling head-on the interrelated issues of fictionality and narrative, late medieval decline, and the deeply-held association between the perceived decline in the quality of source material and perceived social decline.

\subsection{Government: Iceland and the Kings of Norway}

The study of the fourteenth century in Iceland has been dominated by the issues surrounding the end of the Icelandic Commonwealth (sometimes also called 'Free State' in English), and Iceland's subjugation to the kings of Norway after 1262-64. Jón Sigurðsson argued that in 1262, Icelanders entered into a personal relationship with the king of Norway, a relationship which only ended in 1662, when Iceland became subject to Danish rule. ${ }^{22}$ Jón Jóhannesson characterised the fourteenth century by the Icelandic farmers' réttindabarátta (the struggle for rights) against the power of the Norwegian monarchy. ${ }^{23}$ Much more recently (in an ongoing project), Steinar Imsen distinguished between the 'Norse community', which he defines as a loose and fluid geo-ethnic and cultural concept, and the 'Norwegian Domination', which he defines as the 'transformation of Norway and parts of the Norse world into a monarchic state'. ${ }^{24}$ While all very different ways of conceptualising Iceland's

Text: The Theory and Practice of Medieval Historiography (Baltimore, MD: Johns Hopkins University Press, 1997).

${ }^{21}$ Jenkins, Rethinking History, p. 58.

${ }^{22}$ Helgi Porláksson, 'Sagnfræði um Íslandssögu', p. 62.

${ }^{23}$ Jón Jóhannesson, Íslendinga saga, 2 vols (Reykjavík: Almenna bókafélagið, 1956-58), II, pp. 226-301.

${ }^{24}$ Steinar Imsen, 'Chapter 1: Introduction', in The Norwegian Domination and the Norse World c. 1100- c. 1400, ed. by Steinar Imsen, (Trondheim: Tapir Academic Press, 2010), pp. $12-33$ (p. 14). 
relationship with Norway after its subjugation in 1262-64, these models all prioritise the political subjugation of Iceland to Norway and Iceland's newly developed relationship with the Norwegian kings. As we will see, this way of thinking about the fourteenth century has also affected the way that Icelandic scholarship has framed the history of the Church in the later Middle Ages.

\subsubsection{The End of the Icelandic Commonwealth}

From its settlement in the late ninth century, Iceland had maintained a system of governance without a centralised authority. Laws were written and cases were judged by the Althing, an assembly made up primarily of chieftains called goðar (sing. goði), but power was decentralised, and in the hands of the goðar, each with their own followers, to whom the goðar were responsible for protection, legal judgments, and support in their legal cases. ${ }^{25}$ Thus, Iceland was a country without a king or centralised government.

Beginning in around 1200, Icelandic chieftains began to increase their power, and exert influence over larger and larger areas. This led to a concentration of power in the hands of a small group of more powerful chieftains (sometimes called stórgoðar), and in particular the collection of multiple goðorð in the hands of individuals or families. By around 1230, five families and three individuals had divided the country into eight regions, which Jón Viðar Sigurðsson has called domains. ${ }^{26}$ Although they had each amassed territory and supporters, none of the families could achieve supremacy over the others, and a period of civil war and instability set in. This period of unrest is called Sturlungaöld (Age of the Sturlungar), after the most powerful of the families, the descendants of Sturla Pórðarson from Hvammur in Dalir. One of the most popular explanations for the fall of the Commonwealth period is that the king of Norway offered an end to the bloodshed and political uncertainties of this period of civil war. Around 1220, the chieftains began to relinquish their goðorð to the king, and receive them back from

\footnotetext{
${ }^{25}$ This is a condensed account of a heavily researched period of Icelandic history. For a summary of constitutional scholarship, see Jón Viðar Sigurðsson, Chieftains and Power in the Icelandic Commonwealth, trans. by Jean Lundskær-Nielsen (Odense: Odense University Press, 1999), pp. 9-16; see also Jesse Byock, Society, Sagas, and Power; and William Ian Miller, Bloodtaking and Peacemaking.

${ }^{26}$ Jón Viðar Sigurðsson, Chieftains and Power, pp. 62-70.
} 
him in fief. By about 1250, King Hákon owned almost all the chieftaincies in the Northern Quarter, the West Fjords, and the Southern Quarter. ${ }^{27}$ Individual chieftains, like Snorri Sturluson and Gizzur Porvaldsson became the liegemen of the king, and members of the royal court. Thus, the Icelandic aristocracy had already begun to be integrated into the Norwegian court before they were made to swear formal allegiance to the king in 1262 .

In 1258, King Hákon sent the Icelandic goði Gizzur Porvaldsson to Iceland with the title of earl (jarl), and the task of getting the Icelandic chieftains to submit to the Norwegian crown. In 1262 chieftains and the representatives of the farmers from the Northern Quarter and part of the Southern Quarter swore allegiance to King Hákon and his successor Magnús at the Althing. Later that year, representatives from the West Fjords swore their allegiance at a special district assembly. The last Icelandic representatives, from the Eastern Quarter, swore allegiance to the king of Norway in $1264 .{ }^{28}$ A treaty was drawn up at the Althing in 1262 , sometimes referred to as Gizzurarsáttmáli (Gizzur's treaty), sometimes as Gamli sáttmáli (the Old Covenant), although this name is more usually reserved for the second treaty, a renewal of the original agreement, conventionally dated to $1302 .{ }^{29}$

The submission of the Icelanders came as part of a project of expansion which was undertaken by King Hákon Hákonarson at the height of Norwegian power. ${ }^{30}$ In the early years of the reign of King Hákon, the period known as the Norwegian civil wars (c. 1130-1240) came to an end, leading to a period of prosperity for the Norwegian kingdom. In this time, which has historically been known as the 'Golden Age' of the Norwegian medieval kingdom, King Hákon began to exert royal power over all the Norse-speaking colonies of the North Atlantic. In 1261, the Norse-speaking community in Greenland submitted to the authority of the king of Norway, and from 1262-64 the representatives of the farmers of Iceland, as we have seen, did the same. King Hákon died in 1263 in an attempt to retake the

\footnotetext{
${ }^{27}$ Jón Viðar Sigurðsson, Chieftains and Power, p. 76. See also his discussion of the Sturlunga Age, pp. 71-83.

${ }^{28}$ Gunnar Karlsson, Iceland's 1100 Years, p. 82; Jón Jóhannesson, Íslendinga saga, I, pp. 326-31; see also Patricia Pires Boulhosa, Icelanders and the Kings of Norway, pp. 91-106.

${ }^{29}$ Gunnar Karlsson, Iceland's 1100 Years, pp. 82-83. On the textual history of these two documents, see especially Boulhosa, Icelanders and the Kings of Norway, pp. 87-103.

${ }^{30}$ Knut Helle, Norge blir en stat: 1130-1319 (Copenhagen: Universitetsforlaget, 1974), pp. 87-97. On the reign of King Hákon Hákonarson and the ideology of medieval kingship, see Sverre Bagge, From Gang Leader to the Lord's Anointed (Odense: Odense University Press, 1996).
} 
traditionally Norse territory of the Hebrides from King Alexander of Scotland, who had annexed it the previous year. ${ }^{31}$

The events within Iceland which led to the submission to the king of Norway, and particularly the question of why the Icelanders would have agreed to submit to Norway at this time remain one of the central questions of Icelandic historiography. ${ }^{32}$ The details of the practical effects of the submission, however, have not been the focus of a great deal of study, except insofar as they have been thought to have an impact on Icelandic literary tastes. ${ }^{33}$ It is, however, generally believed that many of these effects were not felt immediately. Gizzur jarl carried on as earl of Iceland after 1264 as he had since 1258. More substantial changes probably did not come about until the arrival of a new law code to Iceland in 1271.

\subsubsection{Járnsíða and Jónsbók}

While Icelanders swore their allegiance to the king in 1262-64, the real break with the Commonwealth period came with the introduction of two new law codes, Járnsíða (Iron Side) in 1271, and Jónsbók in $1281{ }^{34}$ King Magnús Hákonarson (1238-80), later nicknamed lagabatir (the law-amender), had embarked on a project of reforming and standardising the regional law codes of Norway. Járnsíða was heavily influenced by Norwegian law; although Jónsbók was slightly less so, it

\footnotetext{
${ }^{31}$ Knut Helle, 'The Norwegian Kingdom: Succession, Disputes and Consolidation', in The Cambridge History of Scandinavia, Volume I: Prehistory to 1520, ed. by Knut Helle (Cambridge: Cambridge University Press, 2003), pp. 369-91 (pp. 385-91).

${ }^{32}$ Most of these are covered by Jón Jóhannesson, Islendinga saga, I, pp. 222-87. The first account to seriously question the nationalist framework of this discussion was that of Sigurður Líndal, 'Utanríkisstefna Íslendinga á 13. öld og aðdragandi sáttmálans 1262-64', Úlfljótur, 17 (1964), 5-36 (16-35). More recently, this question has even been the subject of speculative history, in Sverrir Jakobsson's, 'Pegar Ísland varð hluti af Noregi: Hugleiðing um valkosti sögunnar', Skírnir, 181 (2007), 151-66.

33 See for example Vésteinn Ólason's analysis of two post-Commonwealth sagas, Bandamanna saga and Grettirs saga in Dialogues with the Viking Age, pp. 180-190, as well as his more recent article on fourteenth-century Íslendingasögur, 'The Fantastic Element'.

${ }^{34} J a ́ r n s i ́ ð a$ has recently been edited by Haraldur Bernharðsson, Magnús Lyngdal Magnússon and Már Jónsson, Járnsíða og kristinréttur Árna Porlákssonar (Reykjavík: Sögufélagið, 2005). This edition also includes a good up-to-date bibliography and a thorough overview of recent scholarship and current issues regarding the law code, pp. 13-25. Jónsbók has very recently been translated into English, in Jónsbók: The Laws of later Iceland: The Icelandic Text according to MS AM 351 fol. Skálholtsbók eldri, ed. and trans. by Jana K. Schulman (Saarbrücken: AQ-Verlag, 2010). There is also a recent Icelandic edition, Már Jónsson, ed., Jónsbók: Lögbók Íslendinga, hver sampykkt var á Althingi árid 1281 og endurnýjud um midja 14. öld en fyrst prentud árid 1578 (Reykjavík: Háskólaútgáfan, 2004).
} 
retained the most significant constitutional changes from Járnsíða. Most fundamentally, both law codes codified the king of Norway's rule over Iceland, and placed all legislative powers in his hands.

Járnsíða introduced significant changes to the executive and legislative structure of Iceland. Perhaps most significantly, it abolished the goðar, or chieftains. One of the most notable features of Icelandic law prior to the introduction of Járnsíða was the lack of an executive; the courts could pass judgement, but the enforcement of their judgments was left to the plaintiff. The only penalties in this system were greater and lesser outlawry, and fines payable to the plaintiff; there were no provisions for crimes against the state, and no penalties enforced by the courts, such as imprisonment or execution. ${ }^{35}$ Járnsíða introduced the pegngildi: fines payable to the king for homicide and violations of royal rights. ${ }^{36} \mathrm{~A}$ few years later, Jónsbók introduced capital and corporal punishment, and around the middle of the fourteenth century, the annals begin to record instances of executions. ${ }^{37}$

Additionally, Járnsíða reformed the Althing, especially the Law Council (lögrétta). The Althing consisted of the Law Council, as well as four Quarter courts (fjórðungsdómar) which judged matters for their Quarters, and a Fifth court (fimmtardómar) which judged cases the Quarter courts could not settle. ${ }^{38}$ Under earlier laws, the Law Council had been made up of the goðar (roughly 39-43 individuals, or as many as 50-60; the precise number is matter of dispute), two farmers, and the two bishops. ${ }^{39}$ With the abolition of the goðar in Járnsiða, the Law Council was to consist of thirty-six men from the farmer class (bandur), delegated from the Althing by the king's representative. Járnsíða also abolished the Quarter

\footnotetext{
${ }^{35}$ On the laws of early medieval Iceland, see, Laws of Early Iceland: Grágás, the Codex Regius of Grágás, with Material from Other Manuscripts, trans. by Andrew Dennis, Peter Foote, and Richard Perkins (Winnipeg, MB: University of Manitoba Press, 1980-2000).

${ }^{36}$ Gunnar Karlsson, Iceland's 1100 Years, p. 90.

${ }^{37}$ Már Jónsson, ed., Jónsbók, p. 103. On the court system and punishment before Járnsíða, see Jón Víðar Sigurðsson, Chieftains and Power, pp. 172-76. Storm, Islandske Annaler, pp. $362,363,407,408$, et passim. The early executions in Iceland have not yet been studied.

${ }^{38}$ Laws of Early Iceland, vol. 1, pp. 55-138. The best survey of formal aspects of the Icelandic constitution is Jón Jóhannesson, Íslendinga saga, I, pp. 55-113. Jón Viðar Sigurðsson argued however, that both the Íslendingasögur and the contemporary sagas offer a view of a legal system that worked very differently in practice, see Chieftains and Power.

${ }^{39}$ For the details of the debate regarding the precise number of goðar in the assembly, see Jón Viðar Sigurðsson, Chieftains and Power, pp. 39-60.
} 
courts and the Fifth court, while the Law Council took on the role of appeals court, in the Norwegian style. ${ }^{40}$

Járnsíða remained in force for less than ten years, and was replaced by Jónsbók in 1281. Scholarship relating to the reaction of Icelanders to these new law codes has stressed their reluctance to accept the new law codes; the Icelandic Annals record that it took the Althing two years, from 1271 to 1273, to accept Járnsíða, and Árna saga records the struggles of Lóđinn leppr, the Norwegian emissary who brought Jónsbók to Iceland, to have the law code accepted. ${ }^{41}$ Scholarship to date has focused on identifying the elements of the Icelandic constitution and society which Járnsíða and Jónsbók put an end to, and has emphasised Icelandic resistance to these changes. ${ }^{42}$ What has not yet been attempted, however, is work looking at the effect which these legal changes had on Icelandic society, and the ways in which Icelandic officials and jurists used and interpreted the new legal system.

\subsubsection{The Norwegian Crown and Political Restructuring 1319-97}

After swearing allegiance to the king of Norway in 1263, Icelandic aristocrats began to become members of the Norwegian hirð (court). Membership of the hirð, and the accompanying titles, became an important aspect of aristocratic identity. ${ }^{43}$ As Elizabeth Ashman Rowe has shown, however, dynastic changes within the Scandinavian kingdoms subsequently led to a disintegration of the hirð, and after the mid-fourteenth century Icelanders could no longer rise to power through membership of the hirð, and their connection with the kingdom of Norway weakened. ${ }^{44}$

\footnotetext{
${ }^{40}$ Gunnar Karlsson, Iceland's 1100 Years, pp. 89, 93.

${ }^{41}$ Kónungsannáll, pp. 138-39; Árna saga, pp. 80, 93-100; see also Gunnar Karlsson, Iceland's 1100 Years, p. 90.

${ }^{42}$ This can be seen for instance in the model of Icelandic resistance to Járnsíða, described above. See also Gudmund Sandvik and Jón Viðar Sigurðsson, 'Laws', in Old NorseIcelandic Literature and Culture, ed. by McTurk, pp. 223-44 (p. 226).

43 Jón Viðar Sigurðsson, 'The Icelandic Aristocracy after the fall of the Free State', Scandinavian Journal of History, 20 (1995), 153-66 (pp. 157-58). On the hirð and nobility more generally, see Steinar Imsen, 'King Magnus and his Liegemen's Hirdskrå: a portrait of the Norwegian nobility in the 1270s', in Nobles and Nobility in Medieval Europe. Concepts, Origins, Transformations, ed. by Anne J. Duggan (Woodbridge: Boydell, 2000), pp. 205-22.

${ }^{44}$ Rowe, The Development of Flateyjarbók; see for example pp. 26-27.
} 
From c. 1319 to 1397, the three Scandinavian monarchies underwent a prolonged period of dynastic instability. ${ }^{45}$ As a result of intermarriages, kings often found themselves ruling more than one kingdom. This culminated in 1397 with the institution of the Kalmar Union, by which the kingdoms of Denmark, Sweden and Norway were united under the person of Erik of Pomerania, the young great-nephew of the powerful Queen Margaret of Denmark. ${ }^{46}$ Although the union of all three kingdoms was unstable and quickly dissolved, its consequences for Norway and Iceland were long-lasting.

The most convincing account of the effect of this crisis on Iceland and Icelanders is that of Elizabeth Ashman Rowe, in her analysis of the manuscript Flateyjarbók. $^{47}$ In 1319, King Hákon Magnússon died, leaving the kingdom of Norway to his three-year-old grandson, Magnús Eiríksson, with Magnús' mother Ingibjörg acting as regent. Three years later, Magnús' father King Eric of Sweden died, making Magnús king of Sweden. What was created was a personal union between the kingdoms of Norway and Sweden; the two kingdoms remained distinct, and each retained its Rikisråd (governing council). They were united under the person of the king; this model of union was to be applied to all of the Nordic unions of the fourteenth century and later.

Magnús was raised mostly in Sweden, and chose to be crowned in Stockholm, and his perceived preference for Sweden was cause for concern among the Norwegian nobles. In 1343, responding to increasing dissatisfaction among the Norwegian nobility, King Magnús agreed to give the kingdom of Norway to his younger son Hákon when he came of age; at the same time, he confirmed that his elder son, Eiríkr, would inherit the kingdom of Sweden. When Hákon came of age in 1355 and took control of Norway, the connection between Iceland and Norway which had existed since 1263 was briefly broken: Magnús retained control over Iceland and the territories (Greenland, the Faroe Islands, and the Orkneys), while

\footnotetext{
${ }^{45}$ What follows is based in large part on Jens E. Olsen, 'Inter-Scandinavian relations', in The Cambridge History of Scandinavia, ed by Helle, pp. 710-70. For a detailed discussion of Scandinavian dynastic politics in the first decades of the fourteenth century, see Sverre Bagge, 'Aims and Means in the Inter-Nordic Conflicts 1302-1319', Scandinavian Journal of History, 32 (2007), 5-37.

${ }^{46}$ On the Kalmar Union, see for instance Aksel E. Christensen, Kalmarunionen og nordisk politik 1319-1439 (Copenhagen: Gyldendal, 1980); for a more introductory overview, see Jens E. Olson, 'Inter-Scandinavian Relations' in The Cambridge History of Scandinavia, ed. by Knut Helle, pp. 710-70.

${ }^{47}$ Rowe, The Development of Flateyjarbók.
} 
Hákon held Norway. ${ }^{48}$ As Grethe Authén Blom has shown, this increased the distance between Icelanders and their king; royal officials would often have been forced to travel to Bohus, at the southern end of the border between Sweden and Norway, to see their king. ${ }^{49}$ Although Iceland and Norway were rejoined under King Hákon after the death of his father in 1374, Scandinavian dynastic politics took a distinctive turn towards Danish control after Hákon's death in 1380, and both Norway and its dependencies soon became peripheral.

Scandinavian politics at the end of the fourteenth century were dominated by the figure of Margaret Valdimarsdóttir. Married to King Hákon of Norway in 1363, she had her son Óláfr accepted as king of Denmark after the death of her father in 1375, and as king of Norway in 1380. By 1389, after the unexpected death of her young son, Margaret became regent of Denmark, Norway and Sweden in her own right, and in 1397, she had her adopted son Eric of Pomerania elected king of the three kingdoms in what is known as the Kalmar Union. Margaret accomplished more than any other Scandinavian ruler towards her goal of uniting the Scandinavian countries; at the same time, her apparent disinterest in the affairs of Norway and Sweden, as well as her policy of strengthening Danish rule by appointing Danes to offices in Sweden and Norway led to dissatisfaction in those kingdoms.

In the view of Icelanders, Margaret's accession to the throne of Norway after the death of her son in 1387 was the final blow to the personal relationship which the Icelanders had felt with their king. ${ }^{50}$ Rowe argues that Icelanders were hostile towards Margaret because she was Danish, while Norway, with Icelandic support, had been at war with Denmark more often than not over the course of the century. Moreover, they resented her for being a woman, and took issue with her Birgittine religious views. ${ }^{51}$

Scandinavian royal politics were thus very different by the end of the fourteenth century than they were in the mid-thirteenth, when Iceland became subject to the Norwegian Crown. Over the course of the fourteenth century the kingdom of Norway suffered a severe decline, ending in a union with Denmark after

\footnotetext{
${ }^{48}$ Rowe, The Development of Flateyjarbók; see also Grethe Authén Blom, Magnus Eriksson og Island: Til belysning av periferi og sentrum i nordisk 1300-talls historie, Det Kongelig Norske Videnskabers Selskab, Skrifter, 2 (Oslo: Universitetsforlaget, 1983).

49 Blom, Magnus Eriksson og Island, pp. 26 and 31; Rowe, The Development of Flateyjarbók, p. 95.

${ }^{50}$ This is Rowe's assessment in The Development of Flateyjarbók, p. 27 et passim.

${ }^{51}$ Ibid., p. 27.
} 
1380. Iceland was pushed even further into the periphery, becoming, in the words of Gunnar Karlsson, a 'dependency of a Danish dependency'. 52

Just as important as the actual decline in Norwegian power and influence and their lack of involvement in Iceland and the other territories, were Icelandic perceptions of Norwegian decline. Elizabeth Ashman Rowe has illustrated how Icelandic perceptions of Norway at the end of the fourteenth century focused on the perceived decline in interest in Iceland and a fear of falling into political irrelevance, or of being totally abandoned by Norway. She writes that 'the decline of Norwegian power and prosperity might well have filled Icelanders with a new sort of anxiety, a fear that the parent country had lost interest in or was abandoning its offspring' ${ }^{53}$ Thus, while the beginning of the fourteenth century was marked by Norwegian control in matters of law, administration, and Icelandic membership in the Norwegian hirð, by the end of the fourteenth century matters were in a very different state. The disintegration of Norwegian influence at the end of the century has consequences for any study of the fourteenth century; I will address these issues in more depth at the end of this chapter.

\subsection{The Aristocracy in Iceland and the Administration of Iceland}

I now turn to a discussion of the aristocracy in Iceland and the administration of the country after the submission to the king of Norway. After 1262-64, the aristocracy began to integrate en masse into the Norwegian hirð and receive its power from the king. Moreover, the administrative officials of Iceland, who became in practice the ruling elites of the country, were (at least in theory) in close connection to the king, appointed by him and reporting to him. In the words of Elizabeth Ashman Rowe:

As old as Germania, the ideology of personal relationships had flourished during the Icelandic Commonwealth, when free-men were able to choose which goði (chieftain) they would follow [...] After the Icelanders agreed to accept Norwegian rule in 1263, their ideological framework could accommodate the changing power structure because they swore oaths as individuals to obey the king. As the power structure continued to evolve, however, the gap between reality and ideology grew ever greater.

\footnotetext{
${ }^{52}$ Gunnar Karlsson, Iceland's 1100 Years, p. 103.

${ }^{53}$ Rowe, The Development of Flateyjarbók, p. 79.
} 
The king's officials in Iceland took over the government of the country, and individual Icelanders found it increasingly difficult to join the king's service. ${ }^{54}$

In practice, especially as royal power became more and more distant, and after the union with Denmark made the 'king of Norway' an abstraction, administrative officials and the Icelandic aristocracy took on an identity separate from royal power and from identification with Norway.

\subsubsection{The Administration of Iceland after 1264}

Over the course of the fourteenth century, a system for selecting and maintaining governing officials slowly developed in Iceland. This system has not yet been fully studied, and as a consequence, a great deal remains unknown especially about the early development of these administrative offices. ${ }^{55}$ What is clear is that a stable system of officials did not exist immediately following 1264, or even after 1319 when the administration of Iceland began to be stabilised under Magnús Eiríksson. ${ }^{56}$ On the contrary, it developed slowly over the course of the century. Gunnar Karlsson remarked that, 'the offices did not exist in advance, like boxes to put persons into. What existed were tasks and the king decided to whom they should be entrusted in what size of district and for how long a period' ${ }^{57}$ This is a useful way of thinking about the earliest administrators of Iceland; in particular, it helps to make sense of the noteworthy lack of concern over continuity of titles and offices in the first decades of the fourteenth century. As I will discuss in Chapter 3, a similar pattern can be seen in the development of an ecclesiastical administrative system.

By about the middle of the fourteenth century, many of the features of the administrative system were in place in Iceland. The highest official in the country was the hirðstjori (lit. leader of the hirð, i.e. the Norwegian court). Under the

\footnotetext{
${ }^{54}$ Rowe, The Development of Flateyjarbók, p. 26.

${ }^{55}$ The most detailed analysis of the earliest administrators in Iceland (1300-21) is still Jón Jóhannesson, 'Réttindabarátta Íslendinga í upphafi 14. aldar', in Íslendinga saga, II, pp. 226301. A good, if brief, general survey is provided in Gunnar Karlsson, Iceland's 1100 Years, pp. 89-95; and Jón Viðar Sigurðsson has discussed the social effects of service positions on the Icelandic aristocracy in, 'The Icelandic Aristocracy', especially pp. 156-62.

${ }^{56}$ See Rowe, The Development of Flateyjarbók, p. 21, no. 18.

${ }^{57}$ Gunnar Karlsson, Iceland's 1100 Years, p. 94.
} 
hirðstjóri were two lawmen (lögmenn), and under the lawmen were 6-20 sýslumenn (bailiffs; lit. district-men).

One noteworthy feature of the system was its cyclical nature. Administrators were rotated in, spending a term of 1-3 years in Iceland, then travelled back to Norway to report to the king, or later to the governor of Norway. In some cases, the hirðstjórar would appoint a representative to act as governor in their absence, while in others, new officials would be sent to replace them. ${ }^{58}$ This method of providing administrators meant that the highest secular positions in Iceland were effectively rotated amongst a small group of Icelandic and Norwegian aristocrats. Moreover, it meant that at least a small number of Icelanders travelled back and forth from Norway with regularity. Interestingly, the short terms and frequent rotation of administrative titles may have been a major factor in maintaining the stability of the system. ${ }^{59}$ By rotating the positions of hirðstjóri and lögmenn in three-year cycles, a stable oligarchy of ruling elites could develop in Iceland. None of the major families within Iceland could feel shut out, as the administrative titles rotated amongst them, while Norwegian officials could also be rotated in at stable intervals, to maintain close contact to Norway, and to reward Norwegian supporters of the king.

It is not entirely clear when the position of hirðstjóri became stabilised. In 1258, as discussed above, King Hákon sent Gizzur Porvaldsson to Iceland and gave him the title of 'Earl of Iceland' (jarl yfir Íslandi) ${ }^{60}$ This title was never used again; instead, in 1270 King Magnús sent Hrafn Oddsson and Ormr Ormsson to Iceland, making them his liegemen (handgegna menn). ${ }^{61}$ Ormr died on his way to Iceland, and in 1273, Magnús gave the governance of Iceland to Hrafn and Porvarðr Pórarinsson. After Hrafn and Porvarðr, the governance of Iceland is unclear until around 1320, when Ketill Porláksson and Eiríkr Sveinbjarnarson came to Iceland with power to govern the country.

\footnotetext{
${ }^{58}$ Rowe, The Development of Flateyjarbók, p. 94.

${ }^{59}$ This theory has been developed in the context of the Italian cities, which developed a similar system of government, such that none of the powerful families were shut out of government; see for instance William M. Bowsky, A Medieval Italian Commune: Siena Under the Nine, 1287-1355 (Berkeley, CA: University of California Press, 1981).

${ }^{60}$ Lögmannsannáll, p. 257; Kongungsannáll by contrast, says only that King Hákon 'gaf Gitzvri Porvalldz syni jarls nafn. ok senndi hann til Islanndz.' [gave Gizzur Porvaldsson the name of earl and sent him to Iceland], p. 133.

${ }^{61}$ Jón Jóhannesson, Íslendinga saga, II, p. 76.
} 
Jón Jóhannesson believed that although there is no record of the title hirðstjóri in the Icelandic context before 1320, it was 'obviously older' (sjálfsagt eldri). ${ }^{62}$ No other scholars have attempted to guess at the earliest use of the title in Iceland. Elizabeth Ashman Rowe rather conservatively considered Ívar holmr Vigfússon to be the first hirðstjóri in $1354 .{ }^{63}$ Whether or not they used the title, however, a stable rotation of officials with power over the country can be seen from at least 1341, if not earlier. ${ }^{64}$ It is somewhat outside of the scope of my current project to speculate on the nature of the earliest development of royal administrators in Iceland; similarities to the development of ecclesiastical administrators lead me to believe, however, that the use of the title hirðstjóri to apply to the earliest administrators depends on the individual commentator. Einarr Hafliðason, for example, who loved titles and was one of the first clerical officials to consistently use the titles of officialis and ráðsmaðr (vicar-general), was alone among the fourteenth-century annalists to apply the title of hirðstjóri to Bótólfr Andrésson, the highest official of Iceland from 1341-43. ${ }^{65}$

Below the hirðstjóri were the two lawmen (lögmenn). ${ }^{66}$ This position replaced the older law-speaker (lögsögumaðr) and presided over the Law Council at the Althing, as codified in the legal code Jónsbók. The two lawmen divided their duties regionally, with one lawman for the Northern and Western Quarters, and another for the Southern and Eastern Quarters. Under the lawmen, at the level of local administration, there were officials called sýslumenn (sheriffs). At the beginning of the fourteenth century, there were four or more sýslumenn, but as the position solidified over the course of the later Middle Ages, the country was divided into twenty districts (sýslur), and a sýslumaðr was appointed for each district. The

${ }^{62}$ Jón Jóhannesson, Íslendinga saga, II, p. 77; the record is a letter from King Magnús Eiríksson, in which he bids 'hirðátiora uorum Riddurum uorum hirð uorri oc ollum landzins formonnum' [our hirðstjóri, our knights, our court, and all the leading people of the country] to carry out his commands, DI II, p. 496. The Dictionary of Old Norse Prose catalogues about seven earlier uses of the word from texts dating $c$. 1250-1300, but they all refer to leaders of the Norwegian hirð, or governors of districts within Norway; Dictionary of Old Norse Prosel Ordbog over det norrøne prosasprog (Copenhagen: [Arnamagnæan Commission/Arnamagnæanske kommission], 1983-), s.v. hirðstjóri.

${ }^{63}$ Rowe, The Development of Flateyjarbók, pp. 149 and 291.

${ }^{64}$ See for instance Skálholtsannáll, p. 209.

${ }^{65}$ Lögmannsannáll, p. 273; see also Skálholtsannáll, p. 209 and Gotteskalksannáll, p. 352. On Einarr's appreciation of titles and administrative language, see below, especially Chapters 3.2.1 and 3.2.2.

${ }^{66}$ The information from this paragraph comes primarily from Gunnar Karlsson, Iceland's 1100 Years, pp. 92-95; see also Jón Jóhannesson, Íslendinga saga, II, pp. 82-86. 
twenty syslur roughly corresponded to the thirteen goðorð from the early thirteenth century. ${ }^{67}$ Members of the aristocratic families who dominated these official positions often held two or more positions, sometimes simultaneously, but more often consecutively, and it was not at all uncommon to see a powerful individual who was at the same time sýslumaðr and lögmaðr, or some other combination. ${ }^{68}$

The nationality of the officials appears to have been an issue of some importance in late medieval Iceland; it has certainly been an issue of great importance to contemporary Icelandic historians. The Gamli sáttmáli of 1302 included a stipulation that only Icelanders from the families who had surrendered their goðorð to the king should be appointed as lawmen and sheriffs; this clause has been much debated, alternately interpreted as proof of Icelandic proto-nationalist sentiment, or as an instance of the aristocratic families protecting their own interests. ${ }^{69}$ For the most part, the lögmenn and sýslumenn were Icelanders from the aristocratic families, while the hirðstjórar were either Icelanders or Norwegian officials. $^{70}$

One aspect of the issue of Norwegian governors which has not been explored in much detail is the question of why they would choose to come to Iceland, and how they integrated into Icelandic society. ${ }^{71}$ Some hints to the answer are raised by genealogical research by Jón Jóhannesson and his near contemporary Einar Bjarnason showing that many of these Norwegian officials married into prominent Icelandic families, and that office often stayed within certain Norwegian-Icelandic

${ }^{67}$ Gunnar Karlsson, Iceland's 1100 Years, p. 94.

${ }^{68}$ For a list of the hirðstjórar and lögmenn of late medieval Iceland, see Jón Sigurðsson, 'Lögsögumannatal og lögmanna á Islandi: Með skýringargreinum og fylgiskjölum eptir Jón Sigurdsson', Safn til sögu Islands og islenskra bókmenta, 2, (Copenhagen: Möller, 1886), pp. 4-5. This list is however very flawed, and Jón Johannesson called it 'mjög skakkt' [very wrong], Íslendingasaga, II, p. 243; it has unfortunately not yet been improved upon.

${ }^{69}$ For a summary of this debate, arguing for the side of aristocratic motivations, see Jón Viðar Sigurðsson, 'The Icelandic Aristocracy', pp. 155-56. More radically, Patricia Pires Boulhosa has recently argued that the text of the Gamli sáttmáli, which exists only in fifteenth-century copies, may have been an invention of Icelandic aristocrats in the fifteenth century, looking to protect their rights against the Danish crown in, Icelanders and the Kings of Norway, pp. 87-103.

${ }^{70}$ Gunnar Karlsson, Iceland's 1100 Years, p. 95.

${ }^{71}$ Although Vilborg Auður Ísleifsdóttir has pointed to the close integration of certain Norwegian families into Icelandic society in the context of the last three Norwegian bishops of Hólar, Gottskálk Kenniksson (1442-57), Óláfr Rögnvaldsson (1459-95), and Gottskálk Nikulásson (1496-1520); Vilborg Auður Ísleifsdóttir, Siðbreytingin á Íslandi 1537-1565: Byltingin að ofan (Reykjavik: Hið Íslenska Bókmenntafélag, 1997), p. 73. 
families. $^{72}$ The mid-century hirðstjóri Smiðr Andrésson (1361-62), for instance, was the kinsman of the lawman Hrafn Bótólfsson (1381-90) and genealogical research has suggested that he was also the brother of the previous hirðstjóri Bótólfr Andrésson (1341-43), Hrafn's father. ${ }^{73}$ While Hrafn's father was Norwegian, his mother Steinunn was the daughter of Hrafn Jónsson of Glaumbær, an important aristocrat and a descendant of an old goðorð-holding family. ${ }^{74}$ She and Bótólfr were married in 1342 according to Lögmannsannáll, less than a year after he arrived in Iceland with the king's power over Iceland. ${ }^{75}$ The early date of the marriage might suggest a connection between Bótólfr and Steinunn's family from before Bótólfr's arrival in Iceland. At the least, it suggests a willingness on the part of both Bótólfr and a wealthy, prominent Icelandic family to integrate a Norwegian official into Icelandic aristocratic society. Other examples suggest similarly that Norwegian officials in Iceland developed ties to the aristocracy in Iceland through marriage and friendship after their arrival in Iceland. Moreover, Norwegian officials in Iceland often had family ties to Icelandic government, as did Smiðr. The individual connections between Icelandic and Norwegian communities represent a theme that I will be exploring in relation to Norwegian bishops and clerics working in Iceland, as well as Icelandic clerics travelling in Norway. In that discussion, it will be worth bearing in mind that it was not only Norwegian bishops and members of the clergy who made their lives in Iceland, but also the Norwegian hirðstjórar and officials.

\subsubsection{Leiguhirðstjórar (the rental governors)}

In the middle of the fourteenth century, King Magnús Eiríksson briefly adopted the practice of renting out the governorship of Iceland. As described above, Magnús's son Hákon took the rule of Norway in 1355, while Magnús retained control of Iceland until his death in 1359. Magnús was always short of money, and as Blom has shown,

\footnotetext{
72 Jón Jóhannesson, 'Réttindabarátta Íslendinga í upphafi 14. aldar', in Íslendinga saga, II, pp. 226-301 (see especially pp. 243-45, 280-82, 287); Einar Bjarnason, 'Árni Pórðarson, Smiður Andrésson og Grundar-Helga’, Saga, 12 (1974), 88-108 (pp. 95-97).

${ }^{73}$ Einar Bjarnason, ‘Árni Pórðarson', p. 95; see also Flateyjarannáll, p. 417.

${ }^{74}$ Einar Bjarnason, ‘Árni Bórðarson', p. 95. Hrafn Jónsson was also a participant in two of the earliest preserved Icelandic charters, dated to 1340 and 1332[?] respectively, DI II, pp. 675, 729-30.

${ }^{75}$ Lögmannsannáll, p. 273.
} 
he was interested in using Iceland as a source of revenue. ${ }^{76}$ Beginning in 1354, wealthy individuals could purchase the position of governor (hirðstjóri) of Iceland for a three-year period and were granted especially the right to collect and keep all taxes in the country. ${ }^{77}$ The first of these governors was the Norwegian Vigfús Ívarsson, who arrived in Iceland in 1354, having purchased, according to three Icelandic annals, 'the taxes and all king's powers for three years' ${ }^{78}$ In 1358 , after Vigfús' tenure ran out, the governorship of Iceland was bought by four prominent Icelandic aristocrats; Árni Pórðarson and Andrés úr Mörk were granted governorship over the Eastern and Southern Quarters, and Porsteinn Eyjólfsson and Jón skráveifa Guttormsson were granted governorship over the Northern and Western Quarters. ${ }^{79}$ The last hirðstjóri to have purchased the governorship and right to tax was Smiðr Andrésson, who arrived with the power of hirðstjóri in $1360 .^{80}$ This system of rented governorships for a fixed period led to abuses, as the hirðstjórar did everything they could to make as much money as they could in a fixed time period. The effects of this could be seen already in the governorship of the four Icelandic hirðstjorar; in 1360 nearly 360 men from the Northern Quarter confronted Jón skráveifa in Húnaping, where he was starting a tour of collection and forced him to return south without collecting taxes. ${ }^{81}$ Events came to a head, however, during the tenureship of Smiðr Andrésson. In 1362, Smiðr travelled north to Hólar to adjudicate a dispute between the bishop of Hólar and the priests of the district of Eyjafjörður. He was unable to bring the parties to an agreement, and continued his journey northwards with upwards of thirty armed followers. They met with the forces of the farmers of Eyjafjörður at a farm in Eyjafjörður called Grund on 8 July, 1362. During the battle,

\footnotetext{
${ }^{76}$ Rowe, The Development of Flateyjarbók, p. 149; Blom, Magnus Eriksson og Island, pp. $11,21-32$.

${ }^{77}$ See Jón Jóhannesson, Íslandingasaga, II, p. 79; see also Einar Bjarnason, 'Árni Pórðarson', pp. 97-100.

78 'keypt skattinn og öll kóngsmál um 3 ár', Gottskálksannáll, p. 356; see also Lögmannsannáll, p. 276; and Flateyjarannáll, p. 405.

${ }^{79}$ Flateyjarannáll, p. 406: see also Einar Bjarnason, ‘Árni Pórðarson', p. 88.

${ }^{80}$ Einar Bjarnason, ‘Árni Dórðarson', p. 94.

${ }^{81}$ Rowe, The Development of Flateyjarbók, pp. 149-50; see also Flateyjarannáll, p. 407. The incident is not, however, recorded in Lögmannsannáll, the main source for Flateyjarannáll, although the incident took place in Vesturhóp, Einarr's home district.
} 
referred to as the Grundarbárdagi or Battle of Grund, Smiðr was killed as well as Jón Guttormsson, one of the four Icelandic hirðstjórar from 1358-61. ${ }^{82}$

The Grundarbárdagi was an important event in the eyes of contemporaries. All four of the contemporary annals wrote about the events of the battle, and all four entries contain highly detailed, emotive descriptions of the battle and the events leading up to it. ${ }^{83}$ Flateyjarannáll even includes a six stanza poem commemorating the battle, which is unique in annalistic writing. ${ }^{84}$ Moreover, the battle became the subject of later oral traditions. The most curious of these is perhaps the legends surrounding the figure of Grundar-Helga, the mother of the wealthy and powerful Björn Einarsson. As early as 1508, there is evidence that Grundar-Helga was thought of as the woman 'sem Smið lét taka af' (who had Smiðr killed). ${ }^{85}$ An early twentiethcentury short story by the novelist Jón Trausti tells a story in which Helga planned the attack on Smiðr and his followers and facilitated their defeat by plying them with food and drink on the evening before the battle, so that they were drunk and unprepared for the attack early in the morning. ${ }^{86}$ These stories about Grundar-Helga provide further evidence of the importance of the battle in popular imagination; moreover, it may be possible to learn even more about contemporary attitudes towards the conflict by analysing these traditions. It may be, as Gunnar Karlsson suggested in reference to a different oral tradition (see above, section 1.2.1.), that 'the image of the Icelandic hero as a woman may be seen as expressing a feeling of the utter defencelessness of the country', although that sentiment seems to apply less to a situation in which the armed men of Eyjafjörour were evenly matched with the forces of the Norwegian hirðstjóri. ${ }^{87}$ Perhaps instead the legends of Grundar-Helga speak to a sense of the moral necessity of action against Smiðr Andrésson and

${ }^{82}$ These events have been summarised by Rowe, The Development of Flateyjarbók, pp. 14950, and Björn Porsteinsson, Íslenzka skattlandið (Reykjavík: Prestsmiðjan Hólar, 1956), pp. 171-78.

${ }^{83}$ See Chapter 2.4 for a more detailed discussion of annalistic descriptions of the Grundarbárdagi and the events surrounding it, particularly the conflict between Bishop Jón skalli and the priests of Eyjafjörður.

84 Flateyjarannáll, pp. 409-10; see also Finnur Jónsson, Den Norsk-Islandske Skjaldedigtning: A, Tekst efter håndskrifterne (Copenhagen: Gyldendal, Nordisk forlag, 1912-1915), pp. 396-97. The verses have never been translated into English, and have not yet been edited by the Skaldic Poetry Project.

${ }^{85}$ DI VIII, p. 196; see also Einar Bjarnason, 'Árni Pórðarson', p. 100.

${ }^{86}$ Veislan á Grund', in Jón Trausti, Góðir stofnar: sögur frá fyrri öldum (Reykjavík: Kristjánsson, 1914-15). Full text available online at <http://www.snerpa.is/net/sma/ grund.htm> [accessed 6 November, 2011].

${ }^{87}$ Gunnar Karlsson, Iceland's 1100 Years, p. 121. 
against the rental-governors and their excessive taxation: that all Icelanders, men and women, saw the necessity for action. It would be interesting to see what more detailed analysis of these stories and particularly their transmission might reveal about Icelandic attitudes towards Smiðr and the Battle at Grund. This project, however, has not yet been undertaken.

Recently, Grethe Authén Blom has suggested that the abuses of power displayed by the hirðstjórar might not have merely consisted of squeezing as much money in taxes and fines as possible in a three-year period, but might also reflect ongoing conflicts within Icelandic aristocracy. Private feuds could be carried out in the form of official action against the people of a particular district, and Rowe suggests in particular that the action against the 'people of Eyjafjörður' and the 'people of the north' might have been motivated by private feuds or disputes. ${ }^{88}$ This is a particularly important argument. It has sometimes been suggested that the fourteenth century was a peaceful time, and that feuding as it manifested itself in Commonwealth times ceased to be practiced by the new aristocracy. ${ }^{89}$ It may be the case, as Jón Viðar Sigurðsson has argued, that the Icelandic aristocracy began to feel a sense of solidarity and group identity after the fall of the Commonwealth, and after uniting in their struggle against the Church during staðamál. ${ }^{90}$ It may even have been the case, although I am doubtful, that there was a reduction in aristocratic violence as a result of changes in the nature of elite identity and the power of the Norwegian crown. Research conducted for Germany and the Low Countries, on the other hand, has shown that feuding continued to be practiced in urban and later medieval society in the late Middle Ages and well into the modern period. ${ }^{91}$ Moreover, contrary to Jón Viðar's thesis that a shared group identity led to peace, continental scholarship, following the work of the Austrian historian Otto Brunner, has argued that feud

\footnotetext{
${ }^{88}$ Rowe, The Development of Flateyjarbók, p. 150; see also Blom, Magnus Eiriksson og Island.

${ }^{89}$ Jón Viðar Sigurðsson, ‘The Icelandic Aristocracy', pp. 155-57; see also Gunnar Karlsson, Iceland's 1100 Years, p. 86. One of the most prevalent arguments for why the Icelanders accepted the rule of the king of Norway in 1262 was the promise of an end to civil war (see above, section 1.2.1), an argument which presumes that dependency on the king of Norway was perceived to be relatively peaceful.

${ }^{90}$ Jón Viðar Sigurðsson, 'The Icelandic Aristocracy', p. 157.

${ }^{91}$ On the feud (or vendetta) in the Low Countries, see for instance P.C.M. Hoppenbrouwers, 'Vengeance is Ours? The Involvement of Kin in the Settlement of "Cases of Vengeance"' in Later Medieval Holland', and David Nicholas, The Van Arteveldes of Ghent: The Varieties of Vendetta and the Hero in History (Ithaca, NY: Cornell University Press, 1988).
} 
conducted according to formal rules was an expression of aristocratic class consciousness, and helped to create a sense of group identity among feuding elites. ${ }^{92}$

It is certainly not the case that in Iceland feuding and petty disputes ceased to be practiced, or were drastically reduced after 1300. Only a few instances of secular feuds are recorded in the bishops' sagas and annals of the fourteenth century, and these records are tantalisingly incomplete; they do, however, present a picture of a society in which disputes, feuds, and killings to satisfy honour were as commonplace as in the centuries before. ${ }^{93}$ Crucially however, as Blom's work has suggested, feuding parties after 1300 could use the newly installed mechanisms of service to the king, and the letter of the law to carry out their feuding. The same phenomenon can be observed amongst members of the clergy, although their conflicts are perhaps less accurately labelled 'feuds' as they rarely involved family members, and seldom if ever led to killings. ${ }^{94}$ As will be shown below, members of the clerical elite used their positions as ecclesiastical officials to exact vengeance for private slights, to support their friends and relatives, and to punish their enemies, sometimes using the language and the structures of feud in the process.

\subsection{The Icelandic Church 1264-1300}

The third quarter of the thirteenth century saw a number of significant institutional developments for the Icelandic Church, as a result of a series of reforms at this time. ${ }^{95}$ Many of these reforms closely corresponded to the Gregorian reforms of the eleventh and twelfth centuries. Perhaps the most important of these Gregorian reforms to be enacted in Iceland included the requirement of clerical celibacy, which was enforced in Iceland after 1275, and the struggle to end lay control of church

92 Otto Brunner, Land and Lordship: Structures of Governance in Medieval Austria (Philadelphia, PA: University of Pennsylvania Press, 1992).

${ }_{93}$ An incident was recorded, for instance, in which the steward of Helgafell, Marteinn Másson was killed by a man named Guðlaugr; Marteinn had killed Guðlaugr's father when Guðlaugr was still too young to avenge the killing, Árna saga, p. 46; Flateyjarannáll records in detail an extended feud leading to open battle between Björn Einarsson jórsalafari and Pórðr Sigmundarson, Flateyjarannáll, p. 424.

${ }^{94}$ But see Table 4: 'Killings of Priests 1300-1400'; see also Chapter 4.5.2 on clerical violence in Lárentíus saga.

${ }^{95}$ In this, I follow Orri Vésteinsson's argument in The Christianization of Iceland, especially pp. 209-37. 
property, the staðamál conflict of $1269-97 .{ }^{96}$ A third reform can be seen in the separation of canon law from secular law codes, and the formal acknowlegement of ecclesiastical authority over matters such as marital affairs, and cases involving members of the clergy, or church property. This too, had eleventh- and twelfthcentury parallels in the wider Church, as early reformers vigourously promoted the collection, development, and enforcement of canon law as a tool for legitimising and strengthening Gregorian reform. ${ }^{97}$

The importance of the late thirteenth century reforms in Iceland should not be overstated. As Agnes Arnórsdóttir has effectively shown, there is evidence that Icelandic clerics in the twelfth century or earlier were as familiar with canon law prohibitions on marriage as their southern European counterparts, and that the particular requirements of the Norwegian and North Atlantic Christian communities may even have informed and shaped early papal decretals on marriage restrictions. ${ }^{98}$ Similarly, the earliest attempts to enforce the Gregorian principle of abolishing lay ownership of Church property can be dated to the eleventh century and the episcopate of Porlákr Porhallsson (1178-93), who was also the first recorded bishop in Iceland to attempt to enforce ecclesiastical control over marriage. ${ }^{99}$ At the same time, the influence of canon law in Iceland was formalised with the passing of the New Church Law in 1275, while the effects of staðamál, and particularly the creation of a beneficial system in Iceland, were felt most strongly only after the staðamál conflict of Bishop Árni Porláksson in 1269-97.

${ }^{96}$ On the legal enforcement of clerical celibacy in Iceland, see Orri Vésteinsson, The Christianization of Iceland, pp. 234-37; his account, however, does not adequately address the issues of clerical concubinage, or contemporary attitudes towards the children of priests. By contrast, there is a wide body of scholarship on clerical celibacy and concubinage in wider European scholarship; see especially Jean Gaudemet, 'Le célibat ecclésiastique: Le droit et la pratique du XIe au XIIIe siècle', Zeitschrift der Savigny-Stiftung für Rechtgeschichte Kanonistische Abteilung, 68 (1982), 1-31; and André Vauchez, 'La question du célibat ecclésiastique dans l'Occident médiéval: Un état de la recherche', in Medieval Spirituality in Scandinavia and Europe: A Collection of Essays in Honour of Tore Nyberg, ed. by Lars Bisgaard et al. (Odense: Odense University Press, 2001), pp. 23-32. See also the collection of essays, Medieval Purity and Piety: Essays on Medieval Clerical Celibacy and Religious Reform, ed. by Michael Frassetto (New York, NY: Garland, 1998). See also below, Chapter 4.5.1.

${ }^{97}$ James Brundage, Medieval Canon Law (London: Longman, 1995), pp. 35-43.

${ }^{98}$ Agnes Arnórsdóttir, Property and Virginity, p. 80.

${ }^{99}$ Although there is some debate as to the actual aims and the extent of Bishop Porlákr's reforms as regards Church property; see especially Orri Vésteinsson, The Christianization of Iceland, pp. 117-23. 
I will discuss clerical celibacy in more detail in Chapter 4, in the context of a discussion on clerical concubinage and the children of clerics. In what follows, I discuss the two major legal reforms from the second half of the thirteenth century: the introduction of a beneficial system in Iceland through the dispute known as staðamál, and the adoption of Bishop Árni's New Church Law (Kristinréttr Árna Porlákssonar) in 1275.

\subsubsection{Staðamál}

The earliest churches in Iceland were built by chieftains and farmers on their personal property, and there is evidence to suggest that farmers thought of these churches not only as private property, but as private churches, intended for use by their family. The bishops may, as Orri Vésteinsson suggests, have had the right to be consulted, and may have sometimes been able to leverage their power to consecrate churches to gain influence over the church-owners, but no further rights over property, priests, or churches. ${ }^{100}$ In the twelfth century, farmers began to endow churches with land. ${ }^{101}$ It has been argued that the main push of endowing churches took place in the mid to late twelfth century, and that in the thirteenth century endowments were comparatively modest as ministries and tithing areas had become stable. ${ }^{102}$ When endowing their churches with land, some farmers chose to make their churches staðir. To qualify as a staðr, a church had to own enough of the farm to support a household; usually the entire home-farm, but sometimes a portion of it, if it was a particularly large estate. ${ }^{103}$

In 1269 when Árni Porláksson was consecrated bishop of Skálholt, he was charged by the reforming archbishop Jón rauði with the task of reforming the Icelandic Church. ${ }^{104}$ His specific goal was to achieve ecclesiastical control over churches and their property; in other words, to bring an end to the lay ownership of

\footnotetext{
${ }^{100}$ Orri Vésteinsson, The Christianization of Iceland, p. 106.

${ }^{101}$ On the early endowments of churches, see Orri Vésteinsson, The Christianization of Iceland, pp. 112-32.

${ }^{102}$ Ibid., p. 127.

${ }^{103}$ Ibid., p. 125.

${ }^{104}$ The best account of staðamál is in Magnús Sefansson, 'Frá goðakirkju til biskupskirkju í íslenzkum búningi', in Saga Íslands: Samin að tilhlutan Pjóðhátíðarnefndar 1974, ed. by Sigurður Lindal (Reykjavík: Hið íslenzka bókmenntafélag, 1974-90), III (1978), pp. 111257.
} 
churches, which had been in place in Iceland since the early days of Christianity in Iceland in the early eleventh century. Our main source for Árni's activities is the eponymous Árna saga. ${ }^{105}$ According to the saga, Árni began his efforts to reform the Church in Iceland immediately upon his return to Iceland in 1269. After initial success in the East Fjords, where he took control of all the major staðir without opposition, Árni came upon opposition from the chieftains who held the biggest and wealthiest staðir in Iceland. His first conflict was with the chieftain Ketill Loftsson, who held the church staðr at Hitardalur, but his biggest conflict was with the owners of the staðr of Oddi, who claimed that their mother Steinvörr Sighvatsdóttir had purchased Oddi. In 1272, the case was brought before the archbishop of Niðarós. He was asked to judge whether the staðr at Oddi, and the church at Vatnsfjörðr in the West Fjords, should be handed into the authority of Bishop Árni Porláksson. Archbishop Jón rauði, who had recently won important concessions from King Magnús on the matter of ecclesiastical autonomy, judged in favour of the bishop. ${ }^{106}$

In 1280, King Magnús lagabatir died, leaving his underage son as king of Norway. The council of barons, who together with the queen acted as regents of Norway for the next eight years, were hostile to the Church, and declared void the newly instated New Church Law (see below), and the agreements made between King Magnús and Archbishop Jón rauði. ${ }^{107}$ In 1283-85, with the support of the lawman Hrafn Oddsson, the secular aristocrats took back the staðir which had been appropriated by Bishop Árni. Seventeen staðir are named in Árna saga, all in the diocese of Skálholt, as being seized by their original lay owners in $1284 .{ }^{108}$ Bishop Árni travelled to Norway to petition King Eiríkr in 1288, and ended up staying in the retinue of the king while he was on campaign in Denmark. In 1291, Árni returned to Iceland; in 1295 the king sent a royal decree supporting Árni's position, and in 1297, an agreement was reached in the Treaty of Ögvaldsnes. ${ }^{109}$ Under this agreement, churches which owned the entire home-farm were declared staðir and under the control of the bishop, while those churches that owned less than half of the home-

\footnotetext{
${ }^{105}$ On the textual history of Árna saga, see Chapter 2.2.1.

${ }^{106}$ Gunnar Karlsson, Iceland's 1100 Years, p. 97. On the Concord of Bergen, which laid out the limits of secular and ecclesiastical authority, see Helle, Norge blir en stat, p. 102. For a more recent examination of this agreement, see Lára Magnúsardóttir, Bannfaring og kirkjvald, pp. 320-38.

${ }^{107}$ Helle, Norge blir en stat, pp. 101-05.

${ }^{108}$ Árna saga, p. 119.

${ }^{109}$ DI II, pp. 323-25.
} 
farm were declared bandarkirkjur (farmers' churches) and remained in the control of their lay owners. ${ }^{110}$ Most importantly for my present purposes, in the course of this thirty-year conflict, Bishop Árni and the Icelandic Church established a beneficial system in Iceland. ${ }^{111}$ After gaining control of the staðir, Árni immediately gave them as benefices to powerful clerics. ${ }^{112}$ Although the evidence for the diocese of Hólar is less fulsome for this period, there too, Bishop Jörundr appears to have undertaken the project of establishing a beneficial system. As I will argue in the course of this thesis, it was the establishment of a stable system for allotting staðir as benefices that allowed for the creation of a land-holding class of elite clerics.

The most important source for the staðamál conflict is Árna saga, which follows the life of Bishop Árni Porláksson (bishop of Skálholt 1269-98). ${ }^{113}$ There are several drawbacks to relying so heavily on a single source. Orri Vésteinsson has suggested that Bishop Árni's initial successes in the Eastern Quarter may have been exaggerated by his biographer, either to portray Árni as a successful and dynamic reformer, or to emphasise through contrast the opposition of the chieftains in the Southern Quarter. ${ }^{114}$ Moreover, Árna saga focuses almost exclusively on Bishop Árni and the diocese of Skálholt. Jörundr Porsteinsson, bishop of Hólar during the staðamál conflicts (bishop from 1267-1313) is depicted only in contrast to Bishop Árni, as less steadfast in the dispute. ${ }^{115}$ Finally, as many scholars have lamented, Árna saga's account of staðamál breaks off around 1290, before the resolution of the dispute with the 1297 Treaty of Ögvaldnes. This has primarily been regretted in the context of the staðamál case; there are few details available about reactions to the Treaty of Ögvaldsnes, for example, or about the deliberations leading up to this compromise decision. However, it has also meant that the consequences of staðamál have not been studied as fully as they might have been. In the following chapters, I will return to the consequences of the staðamál conflict for the elite clergy in

\footnotetext{
${ }^{110}$ The best account of this distinction is still Magnús Stefánsson's, Staðir og staðamál; the main points of his argument were also laid out in his earlier 'Frá góðakirkju til biskupskirkju'; see below, Chapter 3.1.3.

${ }^{111}$ Magnús Stefánsson, Staðir og staðamál, p. 48 et passim.

${ }^{112}$ Árna saga, p. 25.

${ }^{113}$ On the textual history of Árna saga, see Chapter 2.2.1.

${ }^{114}$ Orri Vésteinsson, The Christianization of Iceland, p. 132.

${ }^{115}$ Árna saga, pp. 146-47; see also Magnús Stefánsson, 'Frá goðakirkja', pp. 208-09.
} 
Iceland. Here, I will say only that staðamál created a beneficial system in Iceland. ${ }^{116}$ The bishops held the power to grant the staðir and in practice also the bandarkirkjur to clerics as they saw fit. This created new powers for the bishops and the Church, but it also created a new social role for the newly beneficed elite clergy.

\subsubsection{Bishop Árni’s New Church Law}

The role of canon law in late medieval Iceland and the institution of Bishop Árni's New Church Law (Kristinréttr Árna Pórlákssonar) have been the focus of a small number of recent scholarly works. ${ }^{117}$ The New Church Law replaced the older Christian Law section of Grágás, the Icelandic law code from the Commonwealth period. As discussed above, in the late thirteenth century, King Magnús lagabatir (1263-80) attempted to reform Norwegian and Icelandic law. During that project, he came into conflict with archbishop Jón rauði, who wanted to assert control over ecclesiastical law, which before had been included as a section of the regional law codes in Norway (and indeed, in Iceland). ${ }^{118}$ This conflict was ongoing in 1271, when Járnsíða was sent to Iceland; as a consequence, this law code did not contain a section on Christian law. In 1273, Jón rauði won the right to control ecclesiastical law in what is known as the Bergen Concordat. A year later, Bishop Árni came to Iceland with the text of the New Christian law, which was ratified by the Althing in 1275. ${ }^{119}$

Scholars once believed that Bishop Árni's New Church Law had been accepted in the diocese of Skálholt after being ratified by the Althing in 1275, but

\footnotetext{
${ }^{116}$ Magnús Stefánsson, Staðir og Staðamál, p. 48 et passim; see also Jón Jóhannesson, Íslendinga saga, II, p. 108.

117 On canon law in late medieval Iceland, see Lára Magnúsardóttir, Bannfaring og kirkjuvald á Íslandi; on the New Church Law in particular, see also Magnús Lyngdal Magnússon, "Kátt er peim af kristinrétti, kærur vilja margar læra": af kristinrétti Árna, setning hans og valdsviði', Gripla, 15 (2004), 43-90; there is also a new edition of the text with an excellent introduction, Járnsíða og kristinréttur Árna Porlákssonar ed. by Haraldur Bernharðsson, Magnús Lyngdal Magnússon and Már Jónsson (Reykjavík: Sögufélagið, 2005).

${ }^{118}$ On the relationship between King Magnús and Jón rauði, see Knut Helle, Norge blir en stat, pp. 249-53; for a more recent assessment of the settlement at Tunsberg and the issues leading up to it, see Lára Magnúsardóttir, Bannfaring og kirkjuvald, pp. 325-37.

${ }_{119}$ Járnsiða og kristinréttur Árna Porlákssonar, p. 14. In his introduction to the text of the New Church Law, Magnús Lyngdal Magnússon provides an overview of the history of the New Church Law, as well as a good bibliography, pp. 26-44.
} 
that it was not accepted within the diocese of Hólar before the year 1354, when a letter from the king of Norway brought it into law. ${ }^{120}$ Recent scholarship has corrected this understanding. Magnús Lyngdal Magnússon has demonstrated that the New Church Law was officially ratified at around the same time in both dioceses (around 1275), but that the Icelandic bishops struggled to see it upheld in practice without the support of the Norwegian crown. He argued that the king's letter from 1354 came at a time of renewed support for the Church in Norway. ${ }^{121}$

Guðrún Ása Grímsdóttir suggested that the conflicts between farmers and bishops in Hólar in the mid-fourteenth century might have arisen from different views on the law, with the bishops attempting to follow canon law, and the farmers working from Icelandic national laws. ${ }^{122}$ Building on this, Magnús Lyngdal made an interesting argument that the New Church Law was accepted only slowly within Iceland. He pointed to the manuscript transmission of the New Church Law as evidence that, as Guðrún suggested, there were two ecclesiastical laws at work in Iceland in the fourteenth century. In fourteenth-century manuscripts, Bishop Árni's New Church Law is often found together with the Christian Law section of Grágás, the old legal code of Iceland. In fifteenth-century manuscripts, by contrast, the New Church Law is more often found paired with Jónsbók, suggesting that by this time, the New Church Law had been accepted as the only valid Christian law code of Iceland. ${ }^{123}$ More study is needed into the transmission and use of the New Church Law, and particularly into its use and acceptance among the laity.

\subsection{Defining the Period}

The historian Björn Porsteinsson, in his periodisation of Iceland's medieval history, divided the late Middle Ages in Iceland (1264-1500) into two periods: 'Norska Öldin' (The Norwegian Age), stretching from 1264 to 1400, and 'Enska Öldin' (The

\footnotetext{
${ }^{120}$ See for instance, Magnús Sefánsson, 'Frá goðakirkju til biskupskirkju', p. 168. For a recent overview of these arguments, see Magnús Lyngdal Magnússon's introduction to Járnsíða og kristinréttur Árna Porlákssonar, pp. 26-44, especially p. 33.

${ }^{121}$ Járnsíða og kristinréttur, p. 37. This was in the period following the death of King Magnús, when the council of barons was hostile to the Norwegian Church. See Helle, Norge blir en stat, pp. 177-81.

${ }^{122}$ Guðrún Ása Grímsdóttir, 'Formáli’, Biskupa Sögur, III, pp. 1xxiii, lxxviii.

${ }^{123}$ Magnús Lyngdal Magnússon, Járnsíða og kristinréttur, p. 38.
} 
English Age), from 1400 to $1550 .{ }^{124}$ Björn's 'Enska Öldin' makes reference to the increased influence of English merchants trading and fishing in Iceland after c. 1405. 'Norska Öldin', the Norwegian Age, makes reference to the strong influence of the Norwegian crown after 1262-64, and to Norwegian trade in the period up to 1400 . This division of the later Middle Ages in Iceland has received widespread acceptance, and is a useful generalisation. At the same time, however, the influence of trade is less important for my own study than the influences of the Norwegian Church and the papacy, and internal developments within Iceland.

My thesis relies heavily on a prosopographical approach to my sources; by focusing on the careers and lives of the sub-episcopal clergy, I have collected information from a range of sources to create a fuller picture of the Church in fourteenth century Iceland. Most of this chapter has been devoted to discussing the earliest starting-point for my study, namely the period (from roughly 1262 to 1297) during which the legal and constitutional changes to Icelandic society were coming into effect. In practice, however, my prosopographical study begins rather later, in $c$. 1320 , albeit with some exceptions. The reason for this is that it is only by the second and third decades of the fourteenth century that prosopological data can productively be collected. My discussion of events before this date is based instead on the evidence of the bishops' sagas.

The end-date for my study is 1404 , a commonly-used date in Icelandic history, because it was at this time that the Black Death came to Iceland. From 1402 to 1404 , the country experienced death rates as high as $50-60 \%$ of the population. ${ }^{125}$ On the one hand, the significance of the Black Death in Icelandic society should not be overstated, as it does not seem to have been the cause of any real social change. On the contrary, as Gunnar Karlsson and Helgi Skúli Kjartansson have shown, contemporary sources do not even show signs of a temporary disruption of administrative activities. ${ }^{126}$ At the same time, the high mortality rate, estimated to be even higher for members of the clergy, makes 1404 a useful endpoint for a prosopographical study. Contemporary sources suggested a death rate as high as

\footnotetext{
${ }^{124}$ Björn Porsteinsson, Enska öldin í sögu íslendinga, (Reykjavík: Mál og menning, 1970); see also Björn Porsteinsson and Guðrún Ása Grímsdóttir, 'Norska Öldin', in Saga Íslands: Samin að tilhlutan Pjóðhátíðarnefndar 1974, ed. by Sigurður Lindal, 5 vols (Reykjavík: Hið íslenzka bókmenntafélag, 1974-90), IV (1980), pp. 61-258.

${ }^{125}$ Gunnar Karlsson and Helgi Skúli Kjartansson, 'Plágunar miklu á Íslandi', Saga, 32 (1994), 11-74.

${ }^{126}$ Ibid., p. 69.
} 
$80 \%$ for clerics; even if this figure is exaggerated, there can be no doubt that many of the clerics who make up my study died in the period from 1402-04. In the diocese of Hólar, Pórðr Pórðarson, Steinmóðr Porsteinsson, and Halldór Jónsson, three of the most powerful clerics in the diocese, died in the plague. ${ }^{127}$ In Skálholt, Óli Svarthöfðason, the officialis, died early in the fall of the first plague-year (1402), while the ráðsmaðr Höskuldr died on Christmas Day that same year. ${ }^{128}$ Of course, even this chronological constraint is not absolute, and I have occasionally made use of examples from the period after 1404, where relevant.

Although the Black Death provides a useful endpoint for prosopographical study, this project is not simply a biographical study of individual clerics. This is also a study of the development of the Church in the period after the reforms of the late thirteenth century. As I have discussed above, the kingdom of Norway suffered a decline in power and influence throughout the fourteenth century. By about 1380, Norwegian royal influence ceased to be felt within Iceland, although as Rowe has argued, some Icelanders continued to hope for a personal connection to the young King Óláfr until his death in 1387. ${ }^{129}$ The year 1380 also marked a significant shift away from Norway in Icelandic ecclesiastical politics, as I will discuss in more detail in later chapters. After 1380, all bishops in Iceland were appointed by the papacy in Rome. In 1380 the first Danish bishop Michael (his patronymic is unknown) was appointed bishop of Skálholt. ${ }^{130}$ By 1400, both bishops in Iceland were Danish, a trend which would continue into the fifteenth century. ${ }^{131}$ Thus, in discussions of the structures and institutions of the Icelandic Church, this study takes 1380 as an approximate endpoint.

\footnotetext{
${ }^{127}$ Vatnsfjarðarannáll elzti, published in Annálar 1400-1800: Annales Islandici posteriorum saeculorum, 8 vols (Reykjavík: Félagsprentsmiðjan, 1922-2002), III, p. 23.

${ }^{128}$ Lögmannsannáll (Ný Annáll), p. 286.

${ }^{129}$ Rowe, The Development of Flateyjarbók, p. 26 et passim.

${ }^{130}$ On the appointment of bishops, see Chapter 3.3.1; see also Jón Viðar Sigurðsson, 'Island og Nidaros', in Ecclesia Nidrosiensis 1153-1537: Søkelys på Nidaroskirkens og Nidarosprovinsens historie, ed. by Steinar Imsen, Senter for middelalderstudier, 13 (Trondheim: Tapir, 2003), pp. 120-40.

${ }^{131}$ The fifteenth century also saw large numbers of English and Dutch bishops, and a few about whom little is known (see Chapter 6.1). On the appointment of bishops in Iceland, see below, Chapter 3.3.1.
} 


\subsubsection{Currency}

Iceland in the Middle Ages did not have an official currency, and did not mint money. The two most commonly used units of currency were the hundred (hundráð) which represented 120 ells of vaðmál, or homespun woollen cloth, and the kúgildi, the value of a cow. ${ }^{132}$ Although values fluctuated, in the fourteenth century these two units were equal; the value of a cow was measured at one hundred. ${ }^{133}$ At the same time, the distinction between the two was preserved throughout the Middle Ages, and transactions were occasionally carried out in a combination of hundráð and kúgildi. ${ }^{134}$ For this reason, I have maintained the units used in each original source throughout this thesis. An average-sized farm cost about twenty kúgildi (equal to roughly twenty hundráð), while a manor (höfuðból) cost around sixty kúgildi or more. Six sheep could be bought for one kúgildi. ${ }^{135}$

While the hundráð and the kúgildi were the most common units of measurement, others were also in use. Some of these were based on the old Roman system of weights, while others related to Iceland's most common exports, vaðmál and dried fish. For the convenience of the reader, I have provided a list of the units of measurement used throughout this work.

Table 1: Currency and Units of Measurement in Iceland

\begin{tabular}{|l|l|l|}
\hline Unit & ON-Icelandic & Value \\
\hline hundred & hundráð & \\
\hline ell & & 120 ells of vaðmál \\
\hline cow's worth & kúgildi & 10 pennies \\
\hline penny & $\begin{array}{l}\text { penningr, pl. } \\
\text { penningar }\end{array}$ & 1 hundred of vaðmál \\
\hline ertog & ertog & 20 pennies \\
\hline ounce & eyrir, pl. aurar & 60 pennies \\
\hline mark & mark, pl. mörk & 8 ounces \\
\hline quarter & fjörðungar & 20 marks \\
\hline
\end{tabular}

\footnotetext{
${ }^{132}$ To avoid confusion, I will be using the Icelandic hundrád when discussing currency.

${ }^{133}$ Björn Porsteinsson and Guðrún Ása Grímsdóttir, 'Norska Öldin', pp. 135-36.

${ }^{134}$ For instance, the property of Finnstaður í Skagaströnd was bought in 1387 for 15 kugildi and 15 hundráð, DI III, p. 398.

${ }^{135}$ For a further breakdown of the value of commonly-used measures, see Björn Porsteinsson and Guðrún Ása Grímsdóttir, 'Norska Öldin', pp. 135-36.
} 


\begin{tabular}{|l|l|l|}
\hline $\begin{array}{l}\text { weight (hundred- } \\
\text { weight) }\end{array}$ & vatt & 8 quarters \\
\hline
\end{tabular}

\subsection{Conclusion}

The fourteenth century in Iceland has been the focus of relatively little historical research. Much of the work that has been done has focused on the relationship between Iceland and the kings of Norway after 1262-64, and on Iceland's position as a dependent territory, and later as a marginalised dependent territory as Norwegian power waned and Scandinavian interest in the North Atlantic tributary countries faded. With this in mind, scholars have studied the new laws put in place by the Norwegian kings, Járnsíða and Jónsbók. Others have studied political ideology and Icelandic perceptions of kingship, as well as Icelandic participation in the Norwegian royal court, and the changing nature of Icelandic aristocracy as a consequence.

The history of the Icelandic Church, too, has been influenced by this conception of deep-seated changes to Icelandic society and government in the late thirteenth century. Bishop Árni's staðamál and New Church Law brought innovations to Iceland in canon law and ecclesiastical ownership of Church property. These innovations have also been coloured in modern scholarship by the changing relationship between Iceland and Norway. While an earlier generation of scholarship saw these developments negatively, as proof of Norwegian interference in Icelandic society and politics, a more recent generation of scholars has emphasised the canonical nature of these changes, and the desire in both Iceland and Norway to conform to canonical Church practices, and international ecclesiastical decrees. This interpretation too, is influenced by the dichotomy of native Icelandic customs and foreign influence, although not taking such a negative view of imported practices.

While scholars have begun the process of re-evaluating fourteenth-century literary production, much work remains to be done, and much remains unknown about this period and its sources. One major obstacle to the study of the fourteenth century remains the deeply-held view of the fourteenth century as boring and poorly documented. As I have shown, this belief is connected to nationalist views on the nature of Icelandic society in the late Middle Ages, and a view of literary history which connected the decline of literature with the perceived decline of the society 
which produced it. Although scholars are increasingly challenging such beliefs, they remain a powerful factor in the study of Icelandic history.

In the next chapter, I will be describing the source material which I have made use of in the course of this study. As the above discussion makes clear, no description of fourteenth-century sources can ever be neutral; implicit in any assessment of fourteenth-century source material is the historian's perspective on Sigurður Nordal's views on Icelandic literary history, on nationalist views of Icelandic independence and the significance of the events of 1262-64, and on the deeply held dichotomy between European influence and Icelandic uniqueness. 


\section{Chapter Two}

\section{Sources and Authorship: The Intellectual Milieu}

In contrast to the rather bleak picture painted by Orri Vésteinsson and Gunnar Karlsson's assessments of the period, the fourteenth century was an exciting period in the history of writing in Iceland. The fourteenth century was a period of manuscript production; while only a little over 100 manuscripts survive from before 1300, about 300 extant medieval Icelandic manuscripts can be dated to the fourteenth century. ${ }^{1}$ The fourteenth century was also the time of the big manuscript collections; many of the largest and most elaborate codices can be dated to this period, books such as Flateyjarbók, Skarðsbók, and Stjórn. Other important fourteenth-century compilations include Möðruvallabók, the most significant compilation of Íslendingasögur, and Hauksbók, an encyclopaedic compendium compiled and largely written by the lawman Haukr Erlendsson.

In terms of composition, as well, the fourteenth century was a period of major activity. The thirteenth century is generally considered the period in which the composition of sagas of Icelanders was perfected, but full-length Íslendingasögur continued to be composed well into the fourteenth century. Religious literature flourished, including translated hagiographies, Christian skaldic verse, and indigenous bishops' sagas. The fourteenth century also saw the introduction of new genres of writing, in particular the imported romances (riddarasögur). The imported historical genre of annal writing came to Iceland after 1280, and flourished over the course of the fourteenth century. Finally, in the fourteenth century, the use of written records was introduced to Iceland. Over the course of the fourteenth century, collections of records began to be kept at the bishops' seats and monasteries, most notably the máldagarbakur, or bishops' rolls. Transactions such as sales of land, marriages, boundary disputes, legal cases, and so on began to be written down; the use of written contracts and records increased exponentially in the second half of the fourteenth century, in particular.

${ }^{1}$ Guðvarður Már Gunnlaugsson, 'Manuscripts and Paleography', in Old Norse-Icelandic Literature and Culture, ed. by McTurk, pp. 245-64 (p. 250); see also Stefán Karlsson, 'Islandsk bogeksport til Norge i middelalderen', in Stafkrókar, ed. by Guðvarður Már Gunnlaugsson (Reykjavík: Stofnun Árna Magnússonar á Íslandi, 2000), pp. 188-205. 
Literary historians have recently begun the work of re-evaluating the late Middle Ages, rightly criticising the outdated tendency to think of this period in literary history as one of decay and stagnation. In particular, the rise of 'New Philology' has led to increased interest in manuscript production in its own right; an endeavour which leads naturally to an interest in the fourteenth century, the period to which so many of the earliest manuscripts can be dated. ${ }^{2}$ Several new studies have attempted to discuss the literary milieu of the fourteenth century through the study of texts produced in the fourteenth century, but about a time or place far distant from that milieu. ${ }^{3}$ What remains is the impression that material directly about or relating to the fourteenth century is lacking; an impression which is, however, unjustified. On the contrary, perhaps the most exciting characteristic of fourteenth-century literature is the existence of so large a corpus of contemporary historical material; material which described events which took place within living memory of the authors and writers themselves.

\subsection{Source Criticism}

A great deal of source criticism in Icelandic historiography has developed out of the need to engage with the difficulties involved in analysing the Íslendingasögur, fictionalised accounts of Iceland's earliest history written several centuries after the events they describe. Historians have developed sophisticated methods for effectively using thirteenth- and fourteenth-century sources to study Iceland's settlement period and 'heroic age' (c. 870-1200). These methods have drawn heavily on anthropological theory, theories of oral transmission, and literary criticism. ${ }^{4} \mathrm{~A}$ few

\footnotetext{
${ }^{2}$ On 'New Philology' in Old Norse Studies, see especially Matthew Driscoll, 'The Words on the Page: Thoughts on Philology, Old and New', in Creating the Medieval Saga: Versions, Variability and Editorial Interpretations of Old Norse Saga Literature, ed. by Judy Quinn and Emily Lethbridge (Odense: University Press of Southern Denmark, 2010), pp. 85-102.

${ }^{3}$ For an example of this kind of study, see Svanhildur Óskarsdóttir, 'Arctic Garden of Delights: The Purpose of the Book of Reynistaður', in Romance and Love in Late Medieval and Early Modern Iceland, ed. by Kirsten Wolf and Johanna Denzin, Islandica 54 (Ithaca, NY: Cornell University Library, 2008), pp. 279-302.

${ }^{4}$ Theodore Andersson, The Icelandic Family Saga: An Analytic Reading, Harvard Studies in Comparative Literature, 28 (Cambridge MA: Harvard University Press, 1967); Miller, Bloodtaking and Peacemaking; and Gisli Sigurðsson, The Medieval Icelandic Saga and Oral Tradition: A Discourse on Method, trans. by Nicholas Jones, The Milman Parry Collection of Oral Literature, 2 (Cambridge, MA: Harvard University Press, 2004). See also Jón Viðar Sigurðsson, Chieftains and Power.
} 
historians have taken a similar approach to strictly documentary sources; Orri Vésteinsson, for instance, has made extensive use of fourteenth-century records, namely the collections of máldagar (church records) to study eleventh- and twelfthcentury ecclesiastical history. ${ }^{5}$ At the same time, many scholars have emphasised the study of the thirteenth- and fourteenth-century society in which the Íslendingasögur were written, and the sagas' role in that society as a reflection of major social change, as evidence of a learned intellectual milieu, or as a medium of cultural memory. ${ }^{6}$ This methodology has not been applied to the study of the Íslendingasögur alone, but has also been applied to the role of other forms of literature in thirteenthand fourteenth-century Iceland: skaldic verse, Christian hagiographies, and imported romance, to name three that have been the focus of major studies in recent years. ${ }^{7}$

What has been comparatively neglected in all this is a strong critical approach to the so-called 'contemporary sagas', sagas written not long after the events they describe, as well as a critical reassessment of approaches to non-saga sources: the Icelandic annals, and the documentary material preserved from the fourteenth, fifteenth, and sixteenth centuries. On the contrary, scholars have tended to take at face value the historical nature of these sources, without much attempt at source criticism. Working on the thirteenth-century Sturlunga saga, for example, Úlfar Bragason has criticised this neglect, and emphasised the importance of narratology in evaluating the compilation as a historical source. He writes that, 'only by studying the laws of the narrative in Sturlunga is it possible to ascertain what kind of interpretation of contemporary events is contained in the sagas and the compilation, and why'. ${ }^{8}$ Úlfar has pointed to similarities between the narrative methods and structures of Sturlunga to those of the Íslendingasögur, and criticised

\footnotetext{
${ }^{5}$ Orri Vésteinsson has used the fourteenth-century máldagar to study the development of parishes and ministry size in the twelfth century, in The Christianization of Iceland, especially pp. 238-46.

${ }^{6}$ Vésteinn Ólason, Dialogues with the Viking Age; looking at Norse myths rather than sagas, Margaret Clunies Ross, Prolonged Echoes; Old Norse Myths in Medieval Society, vol. 2: The Reception of Norse Myths in Medieval Iceland (Odense: Odense University Press, 1998); Jürg Glauser, 'Sagas of Icelanders and pattir as Literary Representations of a New Social Space', in Old Icelandic Literature and Society, ed. by Margaret Clunies Ross (Cambridge: Cambridge University Press, 2000), pp. 203-20.

${ }^{7}$ Guðrún Nordal, Tools of Literacy: The Role of Skaldic Verse in Icelandic Textual Culture of the Twelfth and Thirteenth Centuries (Toronto, ON: University of Toronto Press, 2001); See also Glauser, Isländische Märchensagas.

${ }^{8}$ Úlfar Bragason, 'Sagas of Contemporary History', in Old Norse-Icelandic Literature and Culture, ed. by McTurk, pp. 427-46 (p. 440).
} 
historians for failing to understand the narrative structure of the Sturlunga saga compilation, as well as the individual sagas within it. ${ }^{9}$

The contemporary bishops' sagas, and Lárentíus saga in particular, have been subject to some narrative analysis, but this has been primarily focused on demonstrating their relationship to the narrative structures and motifs of hagiography. Ásdís Egilsdóttir, in particular, has discussed hagiographic elements in the contemporary bishops' sagas, as well as outlining the narrative structure of the genre of bishop's saga. ${ }^{10}$ As she has shown, the bishops' sagas all follow a remarkably similar narrative structure, based around the life cycle of an Icelandic bishop, from birth, to education, to consecration, to episcopate, to death (and sometimes, to posthumous miracles). This work has been of great importance for the study of the bishop's sagas, particularly in developing an understanding of the genre which transcends long-established divisions between the so-called 'hagiographic' bishops' sagas, and the 'historical', or 'contemporary' bishops sagas; with the latter understood as being more reliable historical sources. ${ }^{11}$ However, much more could be said about the narrative structure of Lárentíus saga and the bishops' sagas, especially the similarities in narrative structures and rhetorical techniques of the later bishops' sagas to the family sagas and the Sturlunga sagas.

Although there is much to be gained by highlighting the similarities in narrative techniques between the contemporary sagas and the Íslendingasögur, this approach still does not address that which is unique to the contemporary sources of the fourteenth century: the immediacy of the events described, and the relationship of the author to those events. Lárentíus saga, written in the third quarter of the fourteenth century, takes the period from 1267-1331 as its subject. Lárentíus saga is a narrative composed after the fact, one which uses saga conventions and

${ }^{9}$ Úlfar Bragason, 'Sturlunga saga: Textar og rannsóknir', Skáldskaparmál, 2 (1992), 176206; see also 'Sagas of Contemporary History'.

${ }^{10}$ Ásdís Egilsdóttir, 'Jarteinir, líkami, sál og trúarlíf', in Sagnaheimur: Studies in honour of Hermann Pálsson on his 80th birthday, 26th May 2001, ed. by Ásdís Egilsdóttir and Rudolf Simek (Vienna: Fassbänder, 2001), pp. 13-19; and 'Biskupasögur og helgar ævisögur', in Biskupa Sögur I: Kristni Saga, Kristni Pattir, Jóns saga ins helga, 2 vols, ed. by Sigurgeir Steingrímsson, Ólafur Halldórsson and Peter Foote, Íslenzk Fornrit, 15 (Reykjavík: Hið íslenzka fornritafélag, 2002), I, pp. viii-xxx. On hagiographic motifs in Lárentíus saga, see also Margaret Cormack, 'Saints' Lives and Icelandic Literature in the Thirteenth and Fourteenth Centuries', in Saints and Sagas, a Symposium, ed. by Hans Bekker-Nielsen and Birte Carlé (Odense: Odense University Press, 1994), pp. 27-47.

${ }^{11}$ For a critical review of the debate, see Ásdís Egilsdóttir, 'Biskupasögur og helgar ævisögur', pp. vii-xviii (especially p. xvii). 
hagiographic motifs to tell its story. Its author was almost certainly Einarr Hafliðason, who himself features in the latter half of the saga, as a pupil, deacon, and clerk for Bishop Lárentius. ${ }^{12}$ In the prologue to the saga, Einarr wrote that he had based the earlier portion of the saga on the testimony of Bishop Lárentius himself, but that he and others had themselves witnessed later events. ${ }^{13}$ The saga is demonstrably influenced by a wide range of literature, including family sagas, saints' lives, and bishops' sagas. At the same time, however, parts of it also represent Einarr Hafliðason's reconstruction of his own lived past and the whole, if the prologue can be taken at face value, represents Einarr's re-interpretation of Bishop Lárentius' oral accounts of his lived past.

Lárentíus saga is not alone among the fourteenth-century sources to display this kind of narrative immediacy. Jóns páttr Halldórssonar contains first-hand accounts from followers of the bishop and appears to have been written by a close follower; moreover, it contains a number of stories which the bishop is said to have recounted himself (see below). Guðmundar saga $C$ ends with an account of Bishop Jörundr Porsteinnson's search for the bones of St Guðmundr told by a narrator intimate with the bishop's household. ${ }^{14}$ Guðmundar saga $D$ includes an account of a miracle witnessed personally by the author, who names himself as 'ek, bróðir Arngrímr' (I, Brother Arngrímr). ${ }^{15}$ Árna saga, although it is has been accurately described as more political in focus than Lárentíus saga and Jóns páttr, has the same immediacy of focus, recounting intimate stories from the life of its hero; it was thought to have been written less than a decade after the death of Bishop Árni Porláksson, possibly by his nephew and successor, Bishop Árni Helgason (130620). ${ }^{16}$

Moving into the realm of non-saga writing, the immediacy of the available accounts becomes even more pronounced. The fourteenth century was also the time of annal-writing and, as I will discuss below, a significant number of annalists were

\footnotetext{
${ }^{12}$ On the authorship of Lárentíus saga, see Guðrún Ása Grímsdóttir, 'Formáli', in Biskupa Sögur, III, pp. lxv-lxvii.

${ }_{14}^{13}$ Lárentíus saga, p. 216.

${ }^{14}$ Peter Foote, 'Bishop Jörundr Porsteinsson and the relics of Guðmundr inn góði Arason', in Studia Centenalia in Honorem Memoriae Benedikt S. Pórarinsson (Reykjavík: Ísafold, 1961), pp 98-114.

${ }^{15}$ There is still no satisfactory edition of Guðmundar saga $D$ (see below, section 2.2.2). The saga has been edited in Biskupa Sögur, ed. by Jón Sigurðsson and Guðbrandur Vigfússon, 2 vols (Copenhagen: Hið íslenzka bókmenntafélag, 1858), II, pp. 1-187.

${ }^{16}$ See below, section 2.2.1.
} 
active in the period after 1360, and after 1395. These accounts are still retrospective; even if told only after a space of a year or a few months, annal entries still represent a retelling of reported and occasionally lived events. However, in the case of these contemporary entries, the annals represent the recording of lived history; events which took place in the lifetime of the annalist. Finally, many of the charters, witness-letters, and other documentary sources written in the fourteenth century exist in their original form; they bear witness to events taking place nearly contemporaneously. Documents and records are a different kind of writing to sagas and historical literature, and will be examined separately. Documents such as witness-letters, however, provides in some ways the most straightforward example of what is unique in a contemporary source: they contain a description of events which took place in the recent past, recorded by one or more witnesses to the event.

To find a historiographical framework for approaching what is unique to the contemporary sagas, we must thus turn from Old Norse-Icelandic historiography, and look to outside scholarship. As discussed above, the narrative structure of the bishops' sagas has most often been studied in comparison to hagiography. A more accurate comparison might be to the lives of bishops written by a close follower of their subject. There are several notable examples of such works in medieval literature, including the life of Anslem of Canterbury by his disciple Eadmer, which has been the focus of two now-classic studies by Richard Southern. ${ }^{17}$ Southern discusses the intimate nature of Eadmer's biography of the bishop, informed both by his own experiences as a disciple of Anselm's, as well as by stories and anecdotes told to him by the bishop. ${ }^{18}$ Additionally, the bishops' sagas might fruitfully be compared to the genre of Gesta episcoporum, accounts of the lives and deeds of the bishops of a particular see. This tradition, which in turn developed out of the influence of the Liber Pontificalis provided a model of biographies of bishops outside of the genre of hagiography. ${ }^{19}$

\footnotetext{
${ }^{17}$ Saint Anselm and his Biographer: A Study of Monastic Life and Thought, 1059-c. 1130 (Cambridge: Cambridge University Press, 1963); Saint Anselm: A Portrait in a Landscape (Cambridge: Cambridge University Press, 1990), see especially pp. 404-36.

${ }^{18}$ Southern, A Portrait in a Landscape, pp. 422-26.

${ }^{19}$ Rosamond McKitterick, 'Roman Texts and Roman History in the Early Middle Ages', in Rome Across Time and Space: Cultural Transmission and the Exchange of Ideas c. 5001400, ed. by Claudia Bolgia, Rosamond McKitterick, and John Osborne (Cambridge, Cambridge University Press, 2011), pp. 19-34 (p. 33).
} 
Although Lárentíus saga, and the other contemporary sagas are not themselves oral accounts, there is an interesting parallel to be drawn to work on the role of narrative and storytelling in oral history, or in the study of orally recounted life stories. The Marxist oral historian Alessandro Portelli studied the role of narrative in workers' oral accounts of industrial conflicts in the United States and in Italy in the post-war period. ${ }^{20}$ Portelli was particularly interested in oral accounts which were contradictory or demonstrably false; in his famous essay, 'The Death of Luigi Trastulli', he studied factually inaccurate accounts of the 1949 death of a young factory worker to demonstrate the emotional significance of massive layoffs at the steel factory in 1952-53. Portelli notes that:

if oral sources had given us "accurate," "reliable", factual reconstructions of the death of Luigi Trastulli, we would know much less about it. Beyond the event as such, the real and significant historical fact which these narratives highlight is the memory itself. $^{21}$

More recently, an interest in narrative research into life stories has developed into an interdisciplinary field of research, closely tied to the discipline of social studies. ${ }^{22}$ Although much of this research is still focused on evidence produced from oral interviews, the study of life stories has also been extended into the study of written sources, including (auto)biographies, CVs, and internet sites such as blogs and homepages, as well as a wide range of other sources. ${ }^{23}$ In the field of medieval studies as well, historians such as Patrick Geary have been interested in narrative, memory, and uses of the past. ${ }^{24}$

Lárentíus saga and the other sources described above are obviously not oral accounts. As medieval texts, they present methodological problems not present in the study of CVs and autobiographies; their claim to immediacy must be qualified by a

\footnotetext{
${ }^{20}$ Alessandro Portelli, The Death of Luigi Trastulli and Other Stories: Form and Meaning in Oral History (Albany, NY: State University of New York Press, 1991).

${ }^{21}$ Portelli, The Death of Luigi Trastulli, p. 26.

${ }^{22}$ See for instance, M. Day Andrews, S. Sclater, C. Squire, and A. Treacher, eds, Lines of Narrative: Psychosocial Perspectives (London: Routledge, 2000); Barbara Harrison, ed., Life Story Research, 4 vols, Sage Benchmarks in social research methods (London: SAGE, 2008).

${ }^{23}$ Barbara Harrison, 'Editor's Introduction': Researching Lives and the Lived Experience', in Life Story Research, pp. xxix-xxxii.

${ }^{24}$ Patrick Geary, Phantoms of Remembrance: Memory and Oblivion at the End of the First Millennium (Princeton, NJ: Princeton University Press, 1994).
} 
thorough understanding of their textual transmission, for instance. ${ }^{25}$ Moreover, the study of life stories and oral history is closely tied to 'history from below', the history of subaltern groups, countercultures, and other marginalised groups; Lárentíus saga and the contemporary sagas are most definitely the history of a small, privileged elite. Bearing these reservations in mind, I would argue, however, that Lárentíus saga, Jóns páttr, some portions of the Icelandic annals, and the other contemporary sources mentioned above share some of the characteristics of 'life stories' or of the oral accounts of Portelli's informants in that they are narrative reconstructions of a lived past. As such, they differ from family sagas, kings' sagas, and other accounts of a more distant past, as well as from romances, exempla, and other fictional stories set in a distant past and far-away places. Moreover, they differ also from other contemporary historical accounts, such as kings' sagas and chronicles, in that their focus is not on 'history', understood as kings and battles, but rather on the history of the personal world of their author. In Lárentíus saga, Einarr Hafliðason recreated an intimate world, centred around Hólar and the ecclesiastical centres of North-Western Iceland; his own home, in other words. He wrote of a close circle of clerical elites, figures who included his father Hafliði Steinsson, his tutor and mentor Lárentius Kalfsson, his school friends and colleagues Árni Lárentiusson, Bergr Sokkason, and Eysteinn rauði, as well as others. He wrote of his own relationship with Bishop Lárentius, but he also wrote Lárentius' personal history. $\mathrm{He}$ wrote of Lárentius' relationship with his own tutors and mentors: his uncle Porarinn kaggi, his first patron Jörundr Porsteinsson, and his most powerful patron Archbishop Jörundr. Often, Einarr's account of Lárentius' life sidestepped the 'grand history' around him, in favour of his mentor's personal experiences. When Lárentius was at the court of King Eiríkr, the saga says nothing of politics, but instead talks at length about the grand impression Lárentius made on the king, and his experience of seeing a fireworks display. ${ }^{26}$ At other times, Einarr wrote Lárentius into the wider historical narrative, always emphasising the effect of events on Lárentius himself

\footnotetext{
${ }^{25}$ Lárentíus saga, for example, has been preserved only in sixteenth-century manuscripts as well as post-medieval copies. However, it is worth mentioning here that in general, the textual transmission of fourteenth-century literature is much more immediate than earlier works; Jóns páttr exists in a fourteenth-century copy, Árna saga is preserved in manuscripts from the mid-fourteenth century, and most of the documents and some of the annals actually exist in their original form (see below).

${ }^{26}$ Lárentíus saga, pp. 236-38.
} 
over the wider political context. ${ }^{27}$ The result is a deeply personal narrative, one which can tell us a great deal about the way that both Lárentius, as the subject, and Einarr, as the author, viewed their world and imagined their past.

Adapted to the context of the written sources of fourteenth-century Iceland, Portelli's study of narrative in oral history accounts will be helpful for using contemporary sources to study not only the events as such, but also the "memory itself', the final product of a reconstruction of the subjects' own lived past, and the meanings that they attached to those stories.

I have been using Lárentíus saga as my primary example so far, and I will continue to rely heavily on evidence presented in this saga in my study of clerical culture in fourteenth-century Iceland. Lárentíus saga is the only full-length bishops' saga written about the fourteenth-century Church. As such it is an important source of information both about the clerical society it describes, and about the preoccupations of its influential writer. However, it is not the only saga of relevance to the study of clerical society in fourteenth-century Iceland and Einarr Hafliðason, though a significant figure, was not an anomalous one. On the contrary, he was a member of a known and influential circle of clerical authors, closely connected to each other, and mostly based in the north, and north-west of Iceland. What follows is a short summary of the development of the bishops' sagas, followed by a more detailed analysis of three bishops' sagas which illustrate the range of literary activity in the early fourteenth century: Árna saga, Jóns páttr Halldórssonar, and Guðmundar saga D.

\footnotetext{
${ }^{27}$ See for example the account of Bishop Jörundr's role in staðamál, and the controversial purchase of Möðruvellir, Lárentíus saga, pp. 234-35.
} 


\subsection{Bishops' Sagas}

The genre of bishops' sagas is understood to include the sagas of six Icelandic bishops, as well as one páttur (short tale) and Hungrvaka, a synoptic account of the first five bishops of Skálholt. ${ }^{28}$ In the past, the bishops' sagas have been divided into two categories, the hagiographic bishops' sagas, and the contemporary or 'historical' bishops' sagas. However, the validity of this division has rightly been questioned in recent years. ${ }^{29}$ In particular, this division obscures the fact that many of the 'hagiographic' bishops' sagas, such as the earliest Porláks saga, the earliest Jóns saga, and the Prestssaga Guðmundar were all written within a generation of the death of their subject. Moreover, it ignores the reality that most of the contemporary bishops' sagas include hagiographic motifs, while many of the hagiographic bishops' sagas include political information and accounts of daily life, much like those in the contemporary bishops' sagas. ${ }^{30}$

As the bishops' sagas can be dated fairly reliably, a more useful distinction might be between the earliest and latest bishops' sagas, as well as between the sagas written shortly after the death of their subject, and those written at a later date. The earliest bishops' sagas are the earliest Porláks saga, written around 1200, Páls saga, written only a few years later, and Hungrvaka, written around the same time. These sagas together provide a continuous history of the seven earliest bishops of Skálholt and may have been written at or near the cathedral of Skálholt. Jørgen Jørgensen has argued that these first bishops' sagas arose from the ecclesiastical politics of the time, namely St Porlákr's reforms, and the beginnings of a division between the goði

\footnotetext{
${ }^{28}$ With the exception of the sagas of Bishop Guðmundr Arason, the bishops' sagas have been recently edited by Íslensk Fornrít: Sigurgeir Steingrímsson, Ólafur Halldórsson and Peter Foote, eds, Biskupa Sögur I: Kristni Saga, Kristni Pattir, Jóns saga ins helga, 2 vols, Íslenzk Fornrit, 15 (Reykjavík: Hið íslenzka fornritafélag, 2003); Ásdís Egilsdóttir, ed., Biskupa Sögur II: Hungrvaka, Porláks Sögu Biskups, Páls saga Byskups, Íslenzk Fornrit, 16 (Reykjavík: Hið íslenzka fornritafélag, 2002); Guðrún Ása Grímsdóttir, ed., Biskupa Sögur III: Árna Saga Biskups, Lárentíus Saga Biskups, Sögupáttur Jóns Halldórssonar Biskups, Biskupa Attir, Íslenzk Fornrit, 17 (Reykjavík: Hið íslenzka fornritafélag, 1998).

${ }^{29}$ For instance by Ásdís Egilsdóttir, 'Biskupasögur og helgar ævisögur', Biskupa sögur, I, pp. viii-xxx; and in 'Jarteinir, líkami, sál og trúarlíf', pp. 13-19. See also Margaret Cormack's account of hagiographic motifs in Lárentíus saga in, 'Saints' Lives and Icelandic Literature'; the division between hagiographic and 'contemporary' bishops' sagas has been maintained, however, by the recent survey of Icelandic literature, Íslensk bókmenntasaga, 3 vols, ed. by Guðrún Nordal et al. (Reykjavík : Mál og menning, 1992), I, pp. 345-57 ('Ævisögur biskupa'), and pp. 473-79 ('Íslenskar játarasögur - Porláks saga og Jóns saga').

${ }^{30}$ Cormack, 'Saints' Lives and Icelandic Literature', especially pp. 39-41.
} 
class and the priests. ${ }^{31}$ These sagas are the first sagas to take Icelanders as their main characters, and Iceland as their main focus. As such, they have been seen as an important link between translated saints' lives and the sagas of Icelanders. ${ }^{32}$

These initial bishops' sagas were imitated by writers in the north of Iceland, and the first life of St Jón Ögmundarson, first bishop of Hólar, was written early in the first half of the thirteenth century. This was followed by the Prestssaga, the life of Bishop Guðmundr góði as a young man and priest, written only a few years after Guðmundr's death in 1237. Shortly after 1300, the life of Bishop Árni Porláksson was written, possibly by his nephew and successor, Bishop Árni Helgason or one of his followers.

The next important period in the history of the bishops' sagas is the period of interest to the current study, i.e. the mid-fourteenth century. From 1315 to $c$. 1341, four separate versions of the saga of Guðmundr gó $i$ were completed. ${ }^{33}$ This same period saw new versions of the life of St Porlákr and the life of St Jón Ögmundarson, as well as the short páttur or tale of Bishop Jón Halldórsson. ${ }^{34}$ Near or after the middle of the century, Einarr Hafliðason wrote Lárentíus saga. In contrast to the first period of bishops' saga writing, these sagas all appear to have been written in the North of Iceland, either at Hólar or at one of the two northern Benedictine monasteries. Just as the first period of bishops' saga writing can be associated with a period of development and reform in the Icelandic Church, the later concentration of religious writing and writing on ecclesiastical politics can be connected to specific

${ }^{31}$ J.H. Jørgensen, 'Hagiography and the Icelandic Bishops sagas', Peritia, 1 (1982), 1-16, (pp. 5-14).

32 Jørgensen ,'Hagiography and the Icelandic Bishops sagas', p. 5.

${ }^{33}$ Stefán Karlsson, 'Guðmundar Sögur Biskups: Authorial Viewpoints and Methods' in Stafkrókar, ed. by Guðvarður Már Gunnlaugsson, pp. 153-71. See also the a study of the growth of the cult of Guðmundr, with a particular focus on the fourteenth-century clerical milieu in northern Iceland in which the multiple versions of his sagas were written; Joanna A. Skórzewska, Constructing a Cult: The Life and Veneration of Guðmundr Arason (11611237) in the Icelandic Written Sources, The Northern World, 51 (Leiden: Brill, 2011).

${ }^{34}$ On the later redactions of Porláks saga, see Ásdís Egilsdóttir, 'Formáli', in Biskupa sögur, II, pp. xxxi-xxxviii; see also Ármann Jakobsson, 'The Friend of the Meek: The Late Medieval Miracles of a Twelfth-Century Saint', in The Making of Christian Myths in the Periphery of Latin Christendom c. 1000-1300, ed. by Lars Boje Mortensen (Copenhagen: Museum Tusculanum, 2006), pp. 135-51 (especially pp. 138-40). On Jóns páttr Halldórssonar, see Guðrún Ása Grímsdóttir, 'Formáli', in Biskupa Sögur, III, pp. cxi-cxiv (see also below, section 2.2.3); on Jóns saga helga and its fourteenth-century redactions, see Peter Foote, 'Formáli: Jóns saga helga', in Biskupa sögur I: Fyrri hluti, pp. ccxx-ccxxxiii. 
political and cultural developments within the Icelandic Church, namely the development of a beneficial culture.

This phase of writing of bishops' sagas can be closely associated with what Marianne Kalinke has referred to as the 'hagiographic renaissance' of the midfourteenth century, and with the group of religious writers which Sverrir Tómasson has named the 'North Icelandic Benedictine School' (Norðlenski Benediktskólinn) of hagiographic writing. ${ }^{35}$ This school was based from the North Icelandic Benedictine monasteries of Pingeyri and Munkapverá, and characterised by a new, more elaborate rhetorical style, as well as a new approach to source material. It is also notable for the fact that a large number of its proponents were named authors, sometimes self-identified, and at other times named by other authors. The North Icelandic Benedictine School has primarily been identified in hagiographic writing, particularly the works of Árni Lárentiusson, Arngrímr Brandsson, and Bergr Sokkason. Árni, the son of Bishop Lárentius of Hólar, was the author of Dunstanus saga, a translation of the Latin vita of the Anglo-Saxon saint. ${ }^{36}$ Arngrímr Brandsson is the author of the version of Guðmundar saga known as Guðmundar saga D, and may also have translated the life of Thomas Becket, Thomas saga erkibyskups. ${ }^{37}$ Bergr Sokkason wrote Nikulás saga, a translation of the life of St Nicholas, and Michaels saga, the life of the Archangel Michael. ${ }^{38}$ Moreover, he has been credited as the author of a redaction of Jóns saga helga, a redaction Guðmundar saga (Guðmundar saga C), Jóns páttr Halldórssonar, as well as a substantial number of sagas, including romances. ${ }^{39}$

${ }^{35}$ Sverrir Tómasson, 'Trúarbókmenntir í lausu máli á síðmiðöld', in Íslensk bókmenntasaga, II, pp. 249-82; Marianne Kalinke, The Book of Reykjahólar, p. 38.

36 Dunstanus Saga, ed. by C.E. Fell, Editiones Arnamagnaeanae, Series B, vol. 5 (Copenhagen: Reitzel, 1963). On Árni Lárentiusson's life and authorship, see the introduction, pp. ix-xci (pp. lix-lxiv).

${ }^{37}$ Sverrir Tómasson, Íslensk Bókmenntasaga, p. 251; the saga is edited in Thomas saga Erkibyskups: Fortelling om Thomas Becket Erkebiskop af Canterbury: To bearbeidelser samt Fragmenter af en tredie, ed. by C.R. Unger (Christiana: Bentzen, 1867). See also Stefán Karlsson, 'Icelandic Lives of Thomas á Becket: Questions of Authorship', in Stafkrókar, ed. by Guðvarður Már Gunnlaugsson, pp. 153-71.

${ }^{38}$ Nikulaus saga and Michaels saga are edited in Heilagra Manna Sögur, ed. by C.R. Unger, 2 vols (Christiania: Bentzen, 1877), I, pp. 676-713 and II, pp. 49-158.

39 Guðmundar saga $C$ has never been published in its entirety, but portions of it have been published by Peter Foote, 'Bishop Jörundr Porsteinsson', pp 98-114. On Bergr Sokkason's authorship of the L-version of Jóns saga helga, see Peter Foote's introduction in Biskupa sögur I: Fyrri hluti, pp. ccxx-ccxxxiii. On Bergr Sokkason's authorship, see Peter Hallberg, Stilsignalment och författarskap $i$ norrön saga literatur (Göteborg: Nordistica 
These authors and their written work are closely connected to the production of bishops' sagas in the mid-fourteenth century. As described above, both Arngrímr and Bergr are credited with the authorship of redactions of Guðmundar saga and Jóns saga helga. Additionally, both Árni Lárentiusson and Bergr Sokkason were contemporaries and school friends of Einarr Hafliðason, the author of Lárentíus saga, and feature prominently in the saga. ${ }^{40}$

\subsection{1. Árna saga}

The oldest manuscript copies of Árna saga are from the mid-fourteenth century, one from no later than 1375 , and one fragment from $c .1340 .{ }^{41}$ The writing of the saga has been dated to sometime between 1300 and 1304, shortly after the death of Bishop Árni Porláksson (1269-98), and has been attributed to Bishop Árni Helgason. ${ }^{42}$ Árni Helgason was the nephew of Árni Porláksson, and the last bishop of Skálholt to be descended from the powerful Haukdælir family, which had been producing bishops of Skálholt from the earliest period of Christianity in Iceland. ${ }^{43}$

Guðrún Ása Grímsdóttir has identified the style of Árna saga as similar to that of Hákonar saga Hákonarson, written by Sturla Porðarson after the king's death in 1263. They both show elements of annal- and chronicle-writing, and may be evidence of the influence of the English chronicler Matthew Paris in Norse writing after $1248 .^{44}$ Moreover, Árna saga is stylistically similar to Sturlunga saga, and in many manuscripts (following the example of Reykjarfjarðarbók) Árna saga follows Sturlunga saga. This is a logical continuation, as chronologically, Árna saga directly follows the Sturlunga period. ${ }^{45}$ The style of Árna saga is factual, with a strong emphasis on political events. Like Sturlunga saga, it contains very little direct speech, a lack which some scholars have considered an indication of 'historical

Gothenburgensis, 1968); Peter Hallberg, 'Some Observations on the Language of Dunstanus saga', Saga Book, 18 (1973), 324-53.

${ }^{40}$ Lárentíus saga, pp. 332-34, 356, 362-70, 382, 418-19.

${ }^{41}$ Guðrún Ása Grímsdóttir, 'Formáli', Biskupa Sögur, III, p. v.

${ }^{42}$ Ibid., pp. xxxiii-xxvii.

${ }^{43}$ On the Haukdælir and their relation to the see of Skálholt, see Orri Vésteinsson, The Christianization of Iceland, pp. 20-21, 158-66 et passim.

${ }^{44}$ Guðrún Ása Grímsdóttir, 'Formáli', Biskupa Sögur, III, p. xvii. See also Narve Bjørgo, 'Om skriftlege kjelder for Hákonar saga', Norsk Historisk Tidskrift, 4 (1967), 185-229.

${ }^{45}$ Guðrún Ása Grímsdóttir, 'Formáli’, Biskupa Sögur, III, p. v. 
intent' ${ }^{46}$ It includes excerpts from letters written to and from high-ranking clerics, as well as from laws and statutes, especially those introduced by Bishop Árni. There is very little information about Bishop Árni's early life, or about his personal habits or daily life at the see, in contrast to Lárentíus saga, for instance. Moreover, there are few signs of the so-called 'florid' or 'Latinate' style which characterises most fourteenth-century learned writing. In all, Árna saga seems to be a late example of an earlier style of writing best characterised by Sturlunga saga; one which resembles a chronicle, uses simple language, and focuses closely on political events. As is true of the Sturlunga collection, this historical style is itself a rhetorical construct, and not the absence of literary form. ${ }^{47}$ In the case of Árna saga, this style marks it as something of an outlier in the literary landscape of fourteenth-century Iceland; a relic of an earlier era, somewhat like its putative author Árni Helgason, the last Icelandic bishop of Skálholt for almost 150 years.

\subsubsection{Guðmundar saga D (Guðmundar saga Arngríms Brandssonar)}

There are a number of versions of the life of Bishop Guðmundr. The first, the Prestssaga Guðmundar byskups, was written shortly after the bishop's death in 1237. It contains an account of the bishop's life as a young man and priest, and is thought to be unfinished. The four sagas of Bishop Guðmundr, known as Guðmundar sögur $A, B, C$, and $D$, were written between the years 1314 and $1344 .{ }^{48}$ Stefán Karlsson, who studied these sagas extensively, has connected the composition of Guðmundar saga $A, B$, and possibly $C$ to Bishop Auðunn's translation of the relics of Bishop Guðmundr in 1314, while Guðmundar saga $D$ was written for the second translation of the relics in 1344 by Bishop Ormr Ásláksson. ${ }^{49}$

\footnotetext{
${ }^{46}$ Theodore Andersson, The Growth of the Medieval Icelandic Sagas (1180-1280) (Ithaca, NY: Cornell University Press, 2006), pp. 153-54.

47 On narrative form in Sturlunga saga, see Úlfar Bragason, 'Sagas of Contemporary History', pp. 433-42.

${ }^{48}$ On the dating of the four versions of Guðmundar saga, see Stefán Karlsson, Guðmundar sögur Biskups I: Avvi Guðmundar Biskups, Guðmundar saga A, Editiones Arnamagnaeanae, Series B, vol. 6 (Copenhagen: C.A. Reitzel, 1983); on the Prestssaga, as well as its connection to the translations, see Stefán Karlsson, 'Guðmundar Sögur Biskups'.

49 Stefán Karlsson, 'Guðmundar Sögur Biskups'; on Guðmundar saga D, see also Jón Helgason, 'Introduction', in Biskupa sogur: MS Perg. fol. No. 5 in the Royal Library of Stockholm (Copenhagen: Einar Munksgard, 1950), pp. 15-21 (especially p. 21).
} 
Guðmundar saga $D$ is the latest of the sagas dealing with St Guðmundr, as well as being stylistically the most different. One of the oldest manuscripts containing this saga, the only version to include verses of skaldic poetry by Arngrímr and Einarr Gilsson, is MS Perg. fol. No. 5, dated to c. 1360, and written at the southern monastery of Pykkvibær. ${ }^{50}$ Jón Helgason, who wrote the introduction to the facsimile edition of this manuscript, considered that Guðmundar saga $D$ was written in the northern Benedictine monastery of Pingeyri shortly after 1344, and brought south to Pykkvibær shortly after. ${ }^{51}$

The saga was written by Arngrímr Brandsson, abbot of Pingeyri from 135162 and officialis of Hólar from 1347-51 and again from 1354-57. ${ }^{52}$ Arngrímr's earlier career has long been the subject of debate; the most convincing synthesis of sometimes contradictory evidence is that of Jón Helgason. ${ }^{53}$ By Jón Helgason's account, Arngrímr began his career as a secular priest, the holder of Oddi and servant of Bishop Jón Halldórsson. He took holy orders in 1341, possibly in the southern friary of Pykkvibær, and became abbot of Pingeyri in 1351. He was a close supporter of the otherwise unpopular Bishop Ormr Ásláksson, during whose episcopate Arngrímr rose to the position of officialis. ${ }^{54}$ It was, moreover, at Ormr's request, and in conjunction with the bishop's 1344 exhumation of the bones of St Guðmundr that Argrímr wrote first a drápa in honour of Bishop Guðmundr, then the saga. ${ }^{55}$

Written in the fourteenth-century 'florid' style, Guðmundar saga D is by far the longest life of Guðmundr the Good, and the most original. It contains a great deal of material not found in any other source, including learned excursus, explicit comparisons between Guðmundr and Thomas Becket, descriptions of Icelandic customs and geography, folkloric material, and skaldic verse. As such, it has

\footnotetext{
${ }^{50}$ Jón Helgason, 'Introduction', in Biskupa segur, p. 10.

${ }^{51}$ Ibid., p. 21.

${ }_{53}^{52}$ However, the evidence for Arngrímr's time as officialis is very thin; see Appendix 2.

53 Jón Helgason, 'Introduction', in Biskupa sogur, pp. 16-18. See also Gustav Storm, 'Forord', Islandske annaler indtil 1578, Det norske hist kildeskriftfando Skrifter, 21 (Christiania: Grøndahl, 1888), pp. i-lxxxiv (pp i-lxviii); Konrad Maurer, Der Elisabeth von Schönau Visionen nach einer isländischen Quelle ([München]: [s.n.], 1883). For a more recent discusson of Arngrímr Brandsson's authorship, see Sverrir Tómasson, Íslensk bókmenntasaga, II, pp. 258-63.

${ }_{55}^{54}$ On the changing meaning of officialis in the early fourteenth century, see Chapter 3.2.2.

55 Jón Helgason, 'Introduction', in Biskupa sogur, p. 21; Sverrir Tómason, Íslensk bókmenntasaga, II, p. 262.
} 
attracted some scholarly speculation as to its purpose and audience. ${ }^{56}$ Jón Helgason and other earlier commentators believed that Guðmundar saga D was based on a Latin original, now lost; this view has been successfully challenged by Stefán Karlsson, although surprisingly it retains some currency in modern scholarship. ${ }^{57}$ It has been suggested for instance that the Latin original may have been intended for a papal audience, as part of a project of official canonisation of the saint. ${ }^{58}$ This seems highly unlikely, partly because of increasing scepticism regarding the existence of a Latin original (or Latin translation), and partly because of the nature of papal politics at this time. After all, Icelandic clerics had little influence in Avignon at this time, and without money or influential supporters, would not have been able to see this project through. It is much more likely that this saga was intended for a Norwegian clerical audience. Many manuscripts were produced in Iceland for Norwegian consumption at this time, and it has long been suggested that Flateyjarbók was written for presentation to the Norwegian king Óláfr. ${ }^{59}$ It is thus not at all unlikely that Guðmundar saga D, as well, was written with a Norwegian audience in mind.

The author of Guðmundar saga D, Arngrímr Brandsson had a place within the circle of writers known as the North-Icelandic Benedictine School of hagiography, as described above. Angrímr's position within this circle is interesting; he is something of an outsider, in that he appears not to have got on with the influential Einarr Hafliðason, and possibly then by extension with Einarr's close companions Bergr Sokkason and Árni Lárentiusson. Einarr's only descriptions of Arngrímr are highly disparaging. ${ }^{60}$ Guðmundar saga $D$, containing as it does so much original material, and especially its commentaries on the clerical milieu of Guðmundr the Good, provides an excellent opportunity to study clerical society in

\footnotetext{
${ }^{56}$ Studies using Guðmundar saga D include Marlene Ciklamini, 'Folklore and hagiography in Arngrímr's Guðmundar saga Arasonar', in The Fantastic in Old Norse/Icelandic Literature, ed. by John McKinnell, David Ashurst and Donata Kick (Durham: The Centre for Medieval and Renaissance Studies, Durham University, 2006), pp. 171-79 and 'The Hand of Revision: Abbot Arngrímr's redaction of Guðmundar saga biskups', Gripla, 8 (1993), 23152; see also Sverrir Tómasson, Íslensk bókmenntasaga, II, p. 351.

${ }^{57}$ For a summary of earlier scholarship on the supposed Latin original, see Jón Helgason, 'Introduction', in Biskupa sogur, p. 15; and Stefán Karlsson, 'Guðmundar Sögur Biskups', p. 163. See however the recent study on the veneration of Guðmundr, which does not reject the idea of a Latin original or intended Latin copy, Skórzewska, Constructing a Cult, especially pp. 26-27.

${ }^{58}$ See Skórzewska, Constructing a Cult, p. 26, no. 36.

59 See Rowe, The Development of Flateyjarbók, pp. 22-25; see also Stefán Karlsson, 'Islandsk bogeksport', pp. 188-205.

${ }^{60}$ Lárentíus saga, pp. 420-21; see also Jón Helgason, 'Introduction', in Biskupa sogur, p. 21.
} 
the middle of the fourteenth century through the study of a text written about a much earlier period.

\subsubsection{Jóns páttr Halldórssonar}

Jóns páttr Halldórssonar is an account of the life of Bishop Jón Halldórsson of Skálholt (1322-39). It is short, only eight pages in the printed edition. ${ }^{61}$ Guðrún Ása Grímsdóttir, the editor of the páttur, has speculated that Jóns páttr was intended as a plan for a full-length bishops' saga, in the same style as Lárentíus saga. ${ }^{62}$ Jóns páttr is, however, a unique piece of writing, one based on a completely different literary tradition from the bishops' sagas; it is unlikely that it was intended as an imitation or a plan of a full-length bishops' saga.

Jóns páttr has been attributed to Bergr Sokkason, a monk at Pingeyri and later abbot of Munkapverá Jóns páttr bears stylistic similarities to many other works attributed to Bergr, and as such is a good example of the so-called 'florid' style of fourteenth-century religious writing. ${ }^{63}$ Jóns páttr also bears some linguistic similarities to the Icelandic romance Clári saga, to the extent that Peter Hallberg has suggested that they were written by the same person, namely Bergr. ${ }^{64}$ There is compelling evidence, however, that Clári saga was in fact composed by Jón Halldórsson; and indeed, its prologue attributes the romance to Jón Halldorsson, although it claims only that he found the story in Latin in France and translated it into Icelandic. ${ }^{65}$ Bergr was known to be a disciple of Bishop Lárentius Kalfsson of

${ }^{61}$ Jóns saga Halldórssonar, in Biskupa Sögur, III, pp. 445-56.

${ }^{62}$ Guðrún Ása Grímsdóttir, 'Formáli', Biskupa Sögur, III, p. cx.

${ }^{63}$ Sverrir Tómasson has described this writing style in some detail, with a particular emphasis on the works of Bergr Sokkason, 'Trúarbókmenntir í lausu máli á síðmiðöld', in Íslensk bókmenntasaga, II, pp. 249-82 (pp. 249-57, 264-68).

${ }^{64}$ Peter Hallberg, "A Group of Icelandic "Riddarasögur" from the Middle of the Fourteenth Century', in Les sagas de chevaliers (riddarasögur): Actes de la Ve Conférence internationale sur les sagas, ed. by Régis Boyer (Paris: Presses de l'Université de ParisSorbonne, 1985), pp. 7-56 (see especially pp. 13-14, 20-21).

${ }^{65}$ Shaun F. D. Hughes, 'Klári saga as an Indigenous Romance', in Romance and Love in Late Medieval and Early Modern Iceland, ed. by Kirsten Wolf and Johanna Denzin, Islandica 54 (Ithaca, NY: Cornell University Press, 2008), pp. 135-164; see also Marianne Kalinke, 'Clári saga: A Case of Low German Infiltration', Scripta Islandica, 59 (2008), 525 . 
Hólar (1324-31), Jón Halldórsson's contemporary. ${ }^{66}$ The evidence of these texts, however, would seem to suggest the strong influence of Bishop Jón Halldórsson on Bergr Sokkason's literary output, and a much nearer relationship between the two men than contemporary evidence would suggest.

Jóns páttr is the only bishops' saga to take as its hero a Norwegian bishop. As such, it does not follow the narrative structure of the bishops' sagas identified by Ásdís Egilsdóttir; the hero's voyage to Norway to be consecrated is inverted, for example. ${ }^{67}$ In fact, however, the narrative is quite different from that of the bishops' sagas, and these differences cannot simply be explained as the result of differences in experiences. Jóns páttr is made up of a series of anecdotal stories with morals (exempla), although these remain structured around the basic narrative framework of the life of the hero, beginning with childhood and ending (more or less) with his good death. The páttur consists, in brief, of two stories about Jón's schooldays, the account of a dream he had once, his death, and an exemplum he once used in a sermon, retold at length. Marteinn Sigurðsson has identified the second story about Jón's school career, a story about a schoolmate in Bologna, as a reworking of a story found in Petrarch's Rerum memorandum libri. ${ }^{68}$ The first story, set in Paris, is recognisably a variant on the 'magician's apprentice' folktale motif; while the schoolboys are forbidden from looking in the master's book, Jón decides to sneak a peak while the master is out of the classroom; this causes uncontrollable storms, which only the master can put right, after Jón confesses what he has done. ${ }^{69}$

Noticeably absent from Jóns páttr is any description of Jón's policies as bishop, or his involvement in Icelandic politics. This is in marked contrast to what is known of Bishop Jón from other sources. Lárentíus saga, the Icelandic annals, Bishop Hákon of Bergen's personal correspondence, and Bishop Jón's own preserved statutes describe the bishop's active role in legal cases (specifically in the so-called Möðruvallamál), as well as his work towards an efficient and centralised

\footnotetext{
${ }^{66}$ Lárentíus saga, pp. 333, 382; see also Sverrir Tómasson, Íslensk bókmenntasaga, II, pp. 249-50.

${ }^{67}$ Ásdís Egilsdóttir, 'Biskupasögur og helgar ævisögur', in Biskupa Sögur, I, pp. viii-xxx (p. $\mathrm{xx})$.

${ }^{68}$ Marteinn Sigurðsson, “"Djöfullinn gengur um sem öskrandi ljón”: Af Jóni Halldórssyni Skálholtsbiskupi, Francesco Petrarca og fornu ljónahliði dómkirkjunnar í Bologna', Skirnir, 2004 (178), 341-48.

${ }^{69}$ Jóns páttr Halldórssonar, p. 446.
} 
ecclesiastical bureaucracy. ${ }^{70}$ Jón Halldórsson was an innovative and influential bishop, a legal expert, and a bureaucrat; the omission of any of this from his páttur serves to further prove how far removed this piece of literature is from any of the bishops' sagas.

In short, Jóns páttr appears to be heavily influenced by preaching, particularly the style of preaching favoured by the Dominicans, or preaching through the use of exempla. Jón Halldórsson was the only Dominican friar to have been made bishop in Iceland; he was one of the few Dominicans known to have journeyed to Iceland at all. ${ }^{71}$ Arnved Nedkvitne has suggested that preaching, in particular the popular preaching practiced by the new mendicant orders, took on an increased importance in Scandinavia over the course of the thirteenth century, and at the start of the fourteenth. ${ }^{72}$ The use of exemplary stories in Jóns páttr may well be further evidence of the important role that preaching through exempla played for the Dominican bishop Jón Halldórsson, and possibly for his biographer, Bergr Sokkason. Moreover, the fluidity between fictional and 'true' stories is made nowhere clearer than in Jóns páttr. The exemplary stories told in Jóns páttr are mostly stories told of Jón's own life, although one is explicitly an exemplum he used in a sermon. As discussed above, however, two of the stories allegedly about Jón's own experiences are re-workings of folkloric material; the saga prefaces these two stories with the statement that 'we will first set forth his adventures (afintýr; a word also used for exempla) in both schools, Paris and Bologna, which took place near him'. ${ }^{73}$ These stories are presumably intended to be attributed directly to Bishop Jón himself. In the previous sentence, the páttur explains that it 'was his [Bishop Jón's] goodwill to gladden the people around him with little-heard exempla (damisögur) which he had learned abroad, both through letters and his own experience, and as a witness thereof, a very small and little [portion thereof] will be set forth in this little book of that great material'. ${ }^{74}$ This would seem to suggest that Bishop Jón himself liked to

\footnotetext{
${ }^{70}$ DI II, pp. 582-94.

${ }^{71}$ The only other Dominican in contemporary sources that I am aware of was Björn, the Dominican friar who accompanied Lárentius on his visitation of Iceland in 1307-09, Lárentíus saga, p. 266 et passim. For more on Björn, see Chapter 5.1.1.

${ }^{72}$ Nedkvitne, The Social Consequences of Literacy, pp. 113-14.

73 'mánum vér í fyrsta stefja sín æfintýr af hvárum skóla, París ok Bolon, er gjörðuz í hans náveru', Jóns páttr Halldórssonar, p. 445.

74 'hverr hans góðvili var at gleðja nærverandis menn með fáheyrðum dæmisögum er hann hafði tekin í útlöndum, bæði með letrum ok eigin raun', Jóns páttr Halldórssonar, p. 445.
} 
make use of stories set in his own past to illustrate moral points; unlike other bishops' sagas, however, the purpose of these stories was the moral point for the audience, rather than emotional resonance for the storyteller, as in Lárentíus saga, or the political relevance of the events related, as in Árna saga.

\subsubsection{Exempla and Romance}

Before moving on to a discussion of non-narrative sources (annals and documents), I want to briefly mention a significant literary development of the fourteenth and fifteenth centuries, namely the development of the riddarasögur, or translated and indigenous romances. Jürg Glauser has argued that the popularity of the riddarasögur in late medieval Iceland can be tied to the rise of a new aristocracy, and especially to a new and newly powerful clergy. ${ }^{75}$ At least two examples of early indigenous romances can be traced with some certainty to members of the small circle of clerical elites in Iceland in the middle of the fourteenth century: Jón Halldórsson's Clári saga, mentioned above, and a romance called Drauma-Jóns saga, which Peter Hallberg has attributed to Bergr Sokkason. ${ }^{76}$ Hallberg has identified three further romances, Kirjalax saga, Rémundar saga keisarasonar, and Dínus saga draumbláta, as being linguistically and stylistically connected to Clári saga; he has suggested that they too, may have been written by Bergr or his school of writers. ${ }^{77}$

Another increasingly popular genre of writing in the fourteenth century in Iceland was the exemplum, known in the vernacular as damisaga or aevintýri. ${ }^{78}$ Although the first examples of individual exempla were known in Iceland around the middle of the thirteenth century, the first major collections of exempla into books were not made until the fourteenth century. ${ }^{79}$ The popularisation of exempla in Iceland is generally associated with Jón Halldórsson, as discussed above. Five

\footnotetext{
${ }^{75}$ Glauser, Märchensagas, pp. 64-78.

${ }^{76}$ Gustaf Cederschiöld, ed., Clári saga, Altnordische Saga-Bibliothek, 12 (Halle: Niemeyer, 1907).

${ }_{78}^{77}$ Peter Hallberg, ‘A Group of Icelandic “Riddarasögur”, especially pp. 13-14.

${ }^{78}$ For a more detailed discussion of Old Norse translations of exempla, see Sverrir Tómasson's overview of the genre in, Íslensk bókmenntasaga, II, pp. 274-77. The exempla have been edited by Hugo Gering, Íslensk aevintyri: Isländische Legenden, Novellen und Märchen, 2 vols (Halle: Verlag der Buchhandlung des Waisenhauses, 1882-1883).

${ }^{79}$ Sverrir Tómasson, Íslensk bókmenntasaga, II, pp. 275-76.
} 
exempla published by Hugo Gering have been attributed to Jón Halldórsson, although this attribution has been called into doubt. ${ }^{80} \mathrm{~A}$ further exemplum with links to a known individual is the Atburð á Finnmörk (Miracle in Finnmark), which was translated from Latin by Einarr Hafliðason in 1381, at the request of brothers Björn and Snorri, friars of Möðruvellir. ${ }^{81}$

There are examples of romances being used as exemplary stories in the German tradition, and as Marianne Kalinke has written, the demarcation between secular narratives and religious literature is not always clear, both serving the double purpose of educating and entertaining. ${ }^{82}$ Late medieval Icelandic literature would seem to be no exception. A manuscript dating to around 1350, AM 657 a-b 4to, serves to further illustrate the connection between romance, religious exempla, and miracle stories. AM 657 is the oldest manuscript to contain the text of Jóns páttr. It also contains Marian miracles, Mikaels saga (written by Bergr Sokkason), DraumaJóns saga, Hákonar páttr Háreksson, and Clári saga, as well as several exempla, which have been published by Hugo Gering. ${ }^{83}$

At the same time it has also been suggested that the presence of the named figure Jón Halldórsson has led scholars to overestimate the number of aefintýri to be composed in the fourteenth century; it has been argued, in particular, that a large collection of religious exempla in Icelandic are translations not from Latin, but from Middle English, and date from the mid-fifteenth century, or later. ${ }^{84}$ However, it does seem clear that a large collection of exempla, as well as a few Icelandic romances, can be clearly connected to Jón Halldórsson and the clerical authors of the early fourteenth century.

${ }^{80}$ Gering, Íslensk aevintyri, II, pp. xxv-lxiv. See also Guðrún Ása Grímsdóttir, 'Formáli', Biskupa Sögur, III, p. cix; and Alfred Jakobsen, Studier i Clarus saga: Til spørsmålet om sagaens norske proveniens (Bergen: Universitetsforlaget, 1964), p. 24. Stefán Karlsson has suggested that the author of some of the relevant exempla is more likely to be Arngrímr Brandsson, 'Icelandic Lives of Thomas á Becket', p. 236.

${ }_{81}$ Alfrceði Íslenzk: Islandsk Encyclopaedisk Litteratur, 2 vols, ed. by Kristian Kålund (Copenhagen: Samfund til udgivelse af gammel nordisk Litteratur, 1908-1918), I (1908), pp. 57-59.

${ }^{82}$ Marianne Kalinke, The Book of Reykjahólar, pp. 18-23.

${ }^{83}$ On AM 657, see Guðrún Ása Grímsdóttir, 'Formáli', Biskupa Sögur, III, p. cxi. See also Gering, Íslensk aevintyri, II, pp. xxv-lxiv.

${ }^{84}$ Peter Alvin Jorgensen, 'Ten Icelandic Exempla and their Middle English Source', Opuscula, 4 (1970), pp. 177-207; Jónas Kristjánsson, 'Bókmenntasaga', in Saga Íslands, III, pp. 261-350 (p. 269). 
The same small group of elite clerical writers responsible for Lárentíus saga, Jóns páttur Halldórssonar, the saints' lives and other religious literature are therefore also closely connected to the translated and native romances which came to Iceland in the fourteenth century, either as authors or audience. As such, an awareness of the themes and contents of the riddarasögur can help to correct some of the omissions from the more explicitly biographical or historical bishops' sagas and annals. One fairly straightforward example of this is the noticeable presence of overtly misogynistic themes in many of the Icelandic romances, including both Clári saga and Drauma-Jóns saga. There is relatively little explicit misogyny in the contemporary historical sagas; a few references in Lárentíus saga could be interpreted as showing a degree of tolerance towards women, but for the most part, the contemporary historical sources (bishops' sagas and annals) simply avoid the topic. ${ }^{85}$ An awareness of themes and issues developed in the riddarasögur can thus shed light on those aspects of clerical identity and ideology which are not made explicit in their conscious self-portraits.

\subsection{The Annals}

The earliest known annals in Scandinavia are from Denmark, the 'Coblaz annals' from the cathedral of Lund, written $c .1137 .{ }^{86}$ The practice spread to other ecclesiastical centres in Denmark in the mid-thirteenth century, and then to Sweden after 1254. Annal-writing came relatively late to Iceland, with the earliest know annals dating to around 1280, while there are no annals preserved from Norway. In mainland Scandinavia, the practice of writing annals declined after 1350. In England, as well, annal-writing was no longer a major form of historical writing by this time. ${ }^{87}$ In both cases, the annals ceased to be relevant because the information they provided could be found more easily elsewhere; chronicles were better for history writing, and documents and registers preserved information such as the terms of kings, popes, and

\footnotetext{
${ }^{85}$ See in particular Einarr's attitude towards clerical concubines, in Lárentíus saga, pp. 259, 299-30. On clerical concubinage, see chapter 4.3.1.

${ }^{86}$ Gunnar T. Westin, 'Årböker', in KLNM, 20, cols 429-35; Herulf Nielsen, 'Årböker: Danmark', in $K L N M, 20$, col. 435; Jakob Benediktsson, 'Årböker: Island', in KLNM, 20, cols 435-37. See also Nedkvitne's discusson of the Scandinavian annals in The Social Consequences of Literacy, pp. 28-30.

${ }^{87}$ Nedkvitne, The Social Consequences of Literacy, pp. 28-30; John Taylor, English Historical Literature in the Fourteenth Century (Oxford: Clarendon, 1987), p. 38.
} 
bishops. ${ }^{88}$ Of course, an important qualification here is that as John Taylor made clear, annals and chronicles were overlapping genres, and there is some artificiality involved in cataloguing a text as one or the other. ${ }^{89}$

In Iceland, annal-writing seems to have come to an end early in the fifteenth century and resumed after the middle of the sixteenth. As Helgi Porláksson has suggested, not enough is known about the political and cultural factors which led to this form of writing being taken up or abandoned. ${ }^{90}$ I would argue, however, that the popularity of this form of writing in the fourteenth and late thirteenth century can be closely tied to the prominent role of clerical elites in the literary production of this period.

In 1888, Gustav Storm published an edition of ten medieval annals; these ten annals are still the basis of what are understood by the Icelandic Annals. ${ }^{91}$ Five of these annals contain substantial notices for the fourteenth century: Skálholtsannáll, Brot af Skálholtsannáll, Lögmannsannáll, Gottskálksanáll, and Flateyjarannáll. It is with these five annals that I am principally concerned.

While the annals have not yet been studied comprehensively, some recent scholarship, most notably the work of Elizabeth Ashman Rowe, has begun to draw attention to the ways in which the textual evidence of the annals can be used as a source of information about the political interests and intellectual environment of the annalists. $^{92}$

The annals, and in some cases the individual notices within them, are composed of a number of layers written by different hands at different times. Scribes could and did leave spaces to be filled in at a later date, go back to add information to earlier entries, add information to entries made by earlier hands, and otherwise

${ }^{88}$ Taylor, English Historical Literature, p. 38.

${ }^{89}$ Ibid., p. 38.

${ }^{90}$ Helgi Porláksson, 'Sagnfræði um Íslandssögu', p. 60.

${ }^{91}$ Islandske annaler indtil 1578, Det norske hist kildeskriftfando Skrifter, 21 (Christiania: Grøndahl, 1888). Oddaverjaannáll, of which Storm published excerpts, has since been edited in its entirety by Eiríkur Pormóðsson and Guðrún Ása Grímsdóttir, eds, Oddaannálar og Oddverjaannáll (Reykjavík: Stofnun Árna Magnússonar á Íslandi, 2003).

${ }_{92}$ Elizabeth Ashman Rowe, 'The Flateyjarbók Annals as a Historical Source', Scandinavian Journal of History, 27 (2002), 233-42. Other works on the Icelandic annals include Björn porsteinsson, 'Síðasta íslenska sagnritið á miðöldum', in Afmcelisrit Björns Sigfússonar, ed. by Björn Teitsson, Björn Porsteinsson, and Sverrir Tómasson (Reykjavík: Sögufélag, 1975), pp. 47-72; J. Helgason, 'Tolf annálagreinar frá myrkum árum', in Sjötíu ritgerðir: Helgaðar Jakobi Benediktssyni 20. júlí 1977, ed. by Einar G. Pétursson and Jónas Kristjánsson (Reykjavík: Stofnun Árna Magnússonar á Íslandi, 1977), pp. 399-418; and Jónas Kristjánsson, ‘Annálar og Î́slendingasögur’, Gripla, 4 (1980), 295-314. 
rewrite earlier work. ${ }^{93}$ Large portions of the annals, especially the earliest entries, could be composed as a single, continuous effort by a single scribe; other portions could have been written in smaller segments, or even year by year. As Rowe has made clear, an interpretation of any given notice must be informed by an understanding of the composition of that notice; some portions of the annals were written years after the fact, while others were probably written year by year; some are copies of earlier annals or of other written sources, while others appear to be based on hearsay or other oral sources. ${ }^{94}$

As my interest is in the fourteenth century, a period in which many annals were composed, I have been predominantly interested in the contemporaneous or near-contemporaneous annal entries. What follows is a brief description of the five fourteenth-century annals, with an emphasis on the portions of the annals relevant to this project. In this, I have relied heavily on Storm's descriptions of the annals, particularly regarding palaeographic and codicological evidence; only two of these annals, Lögmannsannáll and Flateyjarannáll, have been the focus of much individual study.

\subsubsection{Skálholtsannáll}

Skálholtsannáll (Skálholt's annal) is the fifth annal printed in Storm's edition. It is found in the manuscript AM $420 \mathrm{~A}$, and so in its present form begins in the year 140 and ends with an entry for the year $1356 .{ }^{95}$ The manuscript is contemporary, written in a single hand from $c .1362$ or later. The entries for the years 1349-56 were likely a later addition in the original manuscript; they are shorter, and of a different style from the rest of the annal.

The manuscript was found at Skálholt, along with the two manuscript copies of the Lögmannsannáll (see below). ${ }^{96}$ Storm has made strong arguments that the two other annals found in this manuscript collection (AM 420) can be localised, in whole

\footnotetext{
${ }^{93}$ For a more detailed account of the annal-writing process, see Elizabeth Ashman Rowe, 'The Flateyjarbók Annals', pp. 233-35.

${ }^{94}$ Ibid., pp. 237-40.

${ }^{95}$ Storm, 'Forord', in Islandske Annaler, p. xv.

${ }^{96}$ For more on the provenance of this annal, see Storm, 'Forord', in Islandske Annaler, pp. $\mathrm{xV}$-Xviii.
} 
or in part, to the north of Iceland, in spite of their names. ${ }^{97}$ Storm did not speculate as to the origin of Skálholtsannál; my own analysis of the text does not suggest any particular geographic focus. The annal's main interest, if any, is in international events, and it treats the bishops of Skálholt and Hólar more or less equally. Its focus, however, is clearly on ecclesiastical politics, and its origin is probably clerical. Further palaeographic or contextual analysis might reveal more of the origin of Skálholtsannáll; for the purposes of this study, however, it will be assumed that its origin is unknown, but clerical.

\subsubsection{Brot af Skálholtsannáll}

Brot af Skálholtsannáll (Fragment of Skálholt's annal), opens mid-entry for 1328, and ends with an entry for 1372. Storm identified ten different hands in the Brot; the first was responsible for the main text from 1328-62, while later hands filled in entries for two, three or four year intervals, or made single additions to the earlier text. $^{98}$ In other words, the manuscript was first written sometime after 1362, and subsequently added to. Although the fragment was found at Skálholt in the seventeenth century, it must have been written in the Northern Quarter of Iceland, as Storm has argued. He has further suggested that it was likely to have been written at a monastic institution, probably Möðruvellir, as the Brot's account of the priors of this monastery is more complete than any other. ${ }^{99}$ This conclusion is further supported by the annal's treatment of the conflict between Bishop Jón skalli (135990) and the priests and laypeople of Eyjafjörður, the district in which Möðruvellir is located. While the other contemporary account (Lögmannsannáll, see below) is quite heavily biased in favour of the bishop, the Brot seems to have been written from the point of view of the people of Eyjafjörður. Its account of the meeting between Porsteinn Hallsson and Bishop Jón, for example, is told from the point of view of Porsteinn, and is much more sympathetic to the priests of Eyjafjörður than the Lögmannsannáll's account. ${ }^{100}$

\footnotetext{
${ }^{97}$ Storm, 'Forord', in Islandske Annaler, p. xx.

${ }^{98}$ For more on the different hands, see Storm, 'Forord', in Islandske Annaler, p. xx.

${ }^{99}$ Ibid., p. xx.

${ }^{100}$ Brot af Skálholtsannáll, p. 225.
} 


\subsubsection{Lögmannsannáll}

Lögmannsannáll (Lawman's Annal) is one of the most well-known Icelandic annals, as a significant portion of the annal was written by Einarr Hafliðason, in his own hand. ${ }^{101}$ It is found in the manuscript AM $420 \mathrm{~b}$. The section of the annal written by Einarr consists of the entire annal from its beginning (the martyrdom of Peter and Paul) to an entry dated to 1361. Einarr's entry for this year breaks off mid-sentence, and the entry is completed by a second hand. As the second hand in the manuscript continues the annal from 1361-80, Einarr's portion of the annal was probably written before 1380 , and possibly quite close to the date of the final entry, or $1361 .^{102}$ The second hand (1362-80) is likely to have been writing in the North, as was Einarr, and it is possible that the Lögmannsannáll was held at the cathedral of Hólar at the time of the second hand. The third main hand (Storm's fourth hand) wrote entries from 1380-84; both content and handwriting suggest that in this time, the annal was moved to the cathedral centre of Skálholt. ${ }^{103}$ The annal continues until 1430, although the portion from 1393 to 1430 is often referred to as the Nýi Annáll (new annal). This portion is lost in AM $420 \mathrm{~b}$, existing in a sixteenth-century copy (AM 420 c). The Nýi Annáll is significant as the last of the medieval Icelandic annals, and the only annal written in the fifteenth century. ${ }^{104}$

\footnotetext{
${ }^{101}$ For the textual history of Lögmannsannáll, see Rowe, 'The Flateyjarbók Annals', pp. 236-40, and Eldbjørg Haug, 'The Icelandic Annals as Historical Sources', Scandinavian Journal of History, 22 (1997), 263-74. Árni Magnússon was the first to identify Einarr Hafliðason as the author of the Lögmannsannáll; see Storm, p. xxi. For a comparison between Lögmannsannáll and the annalistic material in Lárentíus saga, see Guðrún Ása Grímsdóttir, 'Formáli', in Biskupa sögur, III, pp. lxv-lxvi, and lxxxiv-lxxxviii.

${ }^{102}$ Rowe, 'The Flateyjarbók Annals', p. 239.

${ }^{103}$ Storm, 'Forord', in Islandske Annaler, p. xxii. Although, as the author of Flateyjarannáll made use of Lögmannsannáll up until 1388, it cannot have been moved to Skálholt until after this date; Rowe, 'The Flateyjarbók Annals', p. 234.

${ }^{104}$ Jakob Benediktsson, 'Nýi annáll', in $K L N M, 12$, col. 391. Annal writing resumed early in the sixteenth century, and continued until the nineteenth century.
} 


\subsubsection{Flateyjarannáll}

Flateyjarannáll can be found at the end of the monumental Flateyjarbók. ${ }^{105}$ The annal was compiled by the priest Magnús Porhallsson, the second scribe of the Flateyjarbók, between the years 1388 and 1394. Flateyjarbók was commissioned by Jón Hákonarson of Viðidalstunga, and Flateyjarannáll thus represents the only unambiguously secular Icelandic annal. Until about 1388, Flateyjarannáll consists of a compilation of earlier annals. One of its most significant sources was Lögmannsannáll, which was copied in large part until the entry for $1388 .{ }^{106}$ From then on, Flateyjarannáll seems to have been written year to year, from Magnús' own experience, or contemporary reports; this portion of the annal is significantly more detailed, with much longer entries. Of all the annals, Flateyjarannáll as a whole is the most closely concerned with secular politics; this becomes even more apparent in the independent section. Flateyjarannáll includes more details of the doings of secular aristocrats, most notably a detailed conflict between Björn Einarsson Jorsalafari and Pórðr Sigmundarson in 1393 and 1394.

\subsubsection{Gotteskálksannáll}

Gottskálksannáll differs from the other annals discussed above, in that it was not itself contemporary to the fourteenth-century events it relates. Gottskálksannáll was written in the second half of the sixteenth century, probably by Gottskálk Jónsson, a priest at Glaumbær in Skagafjörður, in the north of Iceland. It remains of interest, however, as a source of information on fourteenth-century events, as well as details of clerical culture, although it must be approached with some caution. Gottskálksannáll is very detailed in its account for the period from c. 1300 to 1394, and Storm has speculated that the portion of this annal for the years 636-1394 was copied from a single older annal, now lost. ${ }^{107}$ This portion of the annal, moreover, records details from the perspective of the see of Skálholt, and thus may be the only

105 Flateyjarannáll is probably the most well-studied of the Icelandic annals, as part of Flateyjarbók. For a summary with references to editorial studies of Flateyjarannáll, see Rowe, 'The Flateyjarbók Annals', especially pp. 233-35.

${ }^{106}$ Which, according to Storm, Magnús must have had access to as AM $420 \mathrm{~b}$, Islandske Annaler, 'Forord', in Islandske Annaler, p. xxxviii.

${ }^{107}$ Storm, 'Forord', in Islandske Annaler, p. xxxi. 
annal to preserve the perspective of this southern see for the period between 1356 (when Skálholtsannáll breaks off) and 1380 (when Lögmannsannáll was moved to Skálholt). At the same time however, the possibility of later interpolation cannot be ignored. Gottskálksannáll contains, for example, the most extensive account of the travels of Brother Eysteinn Ásgrímsson, as well as his conflicts with Bishop Gyrðr of Skálholt. While this could be taken as evidence of the lost annal's focus on Skálholt, it could also reflect a sixteenth-century interest in stories about Brother Eysteinn as the putative author of the Christian skaldic poem Lilja. ${ }^{108}$

Setting aside Gottskálksannáll, then, certain trends can be observed in the writing of these annals. The period directly after 1361 seems to have been an important time in annal-writing; significant portions of three of the four annals may have been written at this time. The entries for the years leading up to 1361 are thus of particular interest; as I will argue below, the content of these entries reflect their closeness to their authors, not just in the length and detail of the entries, but also in the energy and immediacy with which events are related. As well as the period after 1361, the final decade of the fourteenth century was also significant for some annalists. Both Lögmannsannáll and Flateyjarannáll contain important entries for these years; the relevant portion of Gottskálksannáll also comes to an end in 1394.

In terms of location, annal-writing in Iceland appears to have taken place primarily at monastic and ecclesiastical centres, as was the case in mainland Scandinavia. Of the five annals under discussion, three can be associated (with varying degrees of certainty) with particular ecclesiastical centres: Lögmannsannáll with the bishopric of Hólar at first, and later with that of Skálholt, and the Brot af Skálholtsannáll with the Augustinian friary of Möđruvellir. Skálholtsannáll is probably clerical in origin, and probably connected with one of the two bishop's seats, although it cannot be localised with certainty. Flateyjarannáll, on the other hand, can be definitively associated with the secular aristocrat Jón Hákonarson, the manuscript's patron, resident at Viðidalstunga in the north-west of Iceland. It is, of course, hard to say if other monastic institutions, or secular centres of literary activity kept their own annals as well, which have not been preserved.

\footnotetext{
${ }^{108}$ The sixteenth-century annal Oddverjaannáll, for instance, claims that Brother Eysteinn composed Lilja as a penance for slandering Bishop Gyrðr. Storm, Oddverjaannáll, p.489; see Martin Chase's introduction to Lilja, in Poetry on Christian Subjects, ed. by Margaret Clunies Ross, II, pp. 554-55.
} 


\subsection{The Annals as Narrative Sources}

The annals written in Iceland in the later Middle Ages, from roughly 1370 to 1430 have been the focus of very little critical analysis; those written in the sixteenth century and later even less. What critical analysis there has been has been focused to a regrettable degree on the question of reliability; the assumption underlying such attempts is the outdated one that historical research relies on data 'untouched by cosmetics', and must therefore discover the 'biases' in the annals before using the data they present. ${ }^{109}$ In a highly problematic article, Eldbjørg Haug suggested that the Icelandic annals should be seen as narrative sources and examples of history writing, in which past events could be recorded for present purposes, and could not therefore be taken as the pure records of fact that she clearly wanted them to be. ${ }^{110}$ Haug presents this 'bias' in the Icelandic annals as a defect to be overcome by careful source analysis. Many of the flaws in this article have been strongly refuted by Elizabeth Ashman Rowe; however, Rowe does not explicitly refute the assumption that the 'bias' of a narrative source is a defect to be overcome. ${ }^{111}$ More recently, in a deconstructionist account of records of Icelandic shipping practices, Patricia Pires Boulhosa made a similar argument, criticising the practice of using annalistic evidence quantitatively. ${ }^{112}$ Boulhosa argued that there is, "no standard or typical annalistic entry, no formula which is repeated consistently from which statistical, qualitative data can be extracted' ${ }^{113}$ All of these attempts at critical analysis of the Icelandic annals (with the partial exception of Rowe) fail to acknowledge that the narrative characteristics of the Icelandic annals make them more, not less interesting, and more, not less useful to historians. As Portelli makes clear, 'the real and significant historical fact which these narratives highlight is the memory itself'; the Icelandic annals, like Italian workers' accounts of the death of a

109 Otter Dahl, Orunntrekk $i$ historieforskningens metodare (Oslo: Universitetsforlaget, 1967), p. 45; this quotation was taken in translation from Eldbjørg Haug, 'The Icelandic Annals as Historical Sources', p. 264.

${ }^{110}$ Haug, 'The Icelandic Annals as Historical Sources', especially p. 273.

${ }^{111}$ Rowe, 'The Flateyjarbók Annals'; see for instance Rowe's summary of Haug's arguments on p. 240.

112 Patricia Pires Boulhosa, 'Chapter 8: Of Fish and Ships in Medieval Iceland', in The Norwegian Domination, ed. by Imsen, pp. 175-97 (pp. 177-84).

${ }^{113}$ Boulhosa, 'Of Fish and Ships', p. 178. 
young factory worker, would in fact tell us less if they presented an accurate and factual account of the events of fourteenth century Iceland. ${ }^{114}$

What scholars have not yet suggested is that the annals had more in common with 'literary sources' than bias alone; in fact, certain portions of the annals appear to make use of some basic narrative devices. Indeed, the Icelandic annals depart more often than might be expected from what might be termed 'annalistic form', by which often seems to be meant the bare listing of events in notice form. An entry from the Brot af Skálholtsannáll for 1361, illustrates the annals' possible range, as well as a return to 'annalistic form' at the end of the notice:

A dispute arose between Bishop Jón and the clerics and no less the laypeople in Eyjafjörður. Síra Porsteinn and the priests from north of the heath to Ljósávatnsskarð, and laypeople with them, came to Hólar in the Feast of St Catherine because the bishop had promised Síra Porsteinn that the documentation lay at Hólar and when they came to Hólar, the bishop refused speech with them. Síra Porsteinn went up into the room in which the bishop sat and he demanded three times the documentation to prove that he [Bishop Jón] was lawfully bishop of Hólar. The oft-mentioned Porsteinn then said that he was giving up all allegiance to the bishop and all the priests who were with him followed [suit]. The bishop then placed them under a ban, but the priests sang [Mass] as before.

Síra Porsteinn and Porsteinn the farmer bought a ship to travel in to Norway and Óláfr Pétrsson with them. Árni Porðarson the farmer killed by Smiðr. He [Smiðr] made his journey a little while later northwards inland with 30 fully armed people and that was the word that he intended to take to the sword the worthiest farmers in the north. The above-mentioned Smiðr had also called the people of Eyjafjörður traitors and when they learned of such things, they assembled together and went against Smiðr. They met at Grund in Eyjafjörður. There was a battle there in the hall. There Smiðr fell and Jón Guttormsson the lawman and six others of them but five of the people of Eyjafjörður.

Journey abroad of Bishop Jón. Síra Porsteinn driven back. Burning of the church at Valpjófsstaður two days before the Feast of St Tiburtius.

Hofz sunndrlynndi milli lons byskups ok kennimanna ok eigi sidr leikmanna i Eyafirdi. Síra Porsteinn ok prestar fyrir nordan heidar til Liosauaz skarz ok med peim leikmenn komu til Hola in festo Katerine puiat byskup hafdi uænt Síra Porsteini at skilriki lægi at Holum ok er peir komu til Hola uarnati byskup peim uid tals. Síra Porsteinn for upp a herbergi pat er byskup sat i ok krafdi hann prysuar skilrikis til pes at hann ueri logligur Holabyskup. Oft nefndr Porsteinn sagdi ba upp all a hlydni uid byskup ok allir prestar peir er er [sic] honum fylgdu. byskup kalladi pa i banni en prestar sungu sem adr.

Síra Porsteinn $o k$ Porsteinn bonndi keyptu skip at fara at til Noregs ok Olafr Petrs son med peim. drepinn Arni bonndi Pordar son af Smid. bio hann ferd sina litlu sidar

${ }^{114}$ Portelli, The Death of Luigi Trastulli, p. 26; see above, section 2.1. 
nordr um land med xxx manna aluapnatra ok pat ord at at hann ætladi at taka gillduztu bændr fyrir nordan unndr suerd. Nefndr Smidr hafdi $o k$ kallat Eyfirdinga landrapa menn $o k$ er peir frietu puilika hluti sofnuduz peir saman $o k$ foru moti Smid. peir hittuz a Grvnd i Eyafirdi. uard par bardagi i skalanum.. par fiell Smidr ok lon logmadr Gutorms son ok vj. adrir af peim en .v. af Eyfirdingum.

Vtanferd Ions byskups. Síra Porsteinn uard aftrreka. [Kirkiv bruni a Valpiofstoðvm .ij. nottvm firir Tiburcius messo.]. ${ }^{115}$

I have quoted at length to demonstrate the structure of the annal entry as a whole and the way in which it functions as more (and less) than just a list of events for that year. Seen as a whole, this entry is clearly not organised as a list of facts. It is presented in narrative form, or more accurately, in the form of two main narratives, the story of the conflict between Porsteinn Hallsson and his followers and Bishop Jón skalli, and the story of the battle of Grund in Eyjafjörður. Within these two stories there is an explicit causal link between events: Porsteinn and his followers came to Hólar because the bishop had promised to show them a document of proof (skilriki); the farmers of Eyjafjörður assembled because they had heard the rumours of Smiðr's journey north. A more subtle link connects the conflict between the priests and laypeople of Eyjafjörður and Bishop Jón to the armed conflict between the farmers of Eyjafjörður and Smiðr and his followers. The connection is made only by the juxtaposition of the two events, and might be explained away as simply the choppy style of an annalist, jumping from one event of note to another. This entry, however, on the whole, displays a remarkable level of consistency. The similarities between the two conflicts are highlighted: in both cases, the people of Eyjafjörður are united in conflict with a seemingly more powerful enemy. In both cases it is the enemy of the people of Eyjafjörður who is seen to have initiated the conflict: Bishop Jón provokes Porsteinn Hallsson and his followers by refusing to show them the document as promised, and by refusing to speak with them upon their arrival; in the second conflict, the farmers of Eyjafjörður are provoked to action by the news that Smiðr was journeying north with 30 armed men, and by the news that he had called them traitors and intended to attack and kill them. In both conflicts, although no clear victor can be identified, the annalist is able to highlight the victories of the people of Eyjafjörður: the priests under Porsteinn's leadership defy the bishop's ban and

${ }^{115}$ Brot af Skálholtsannáll, pp. 225-26. The final portion in brackets is an addition by a later hand. See Storm's note to the text, p. 226, no 1. 
continue to sing Mass, and the losses of the farmers of Eyjafjörður are less than the losses of Smiðr's party, which include himself and Jón Guttomrsson the lawman.

Even the short entries at the end contribute to the single narrative. These are clearer examples of 'annalistic style' than can be seen anywhere else in this entry: they are short, and do not consist of full sentences. With the exception of the final notice, however, written later by a different scribe, these short notices contribute to the entry as a whole. Bishop Jón, who had been involved in this divisive conflict with Porsteinn Hallsson and his supporters, journeys to Norway, presumably to present the case to the archbishop and to demand his support. Síra Porsteinn's journey, mentioned in the body of the entry, was aborted when he was driven back (varð aftrreka).

Gustav Storm, in his analysis of the Brot af Skálholtsannáll, suggested that this annal might have been written at the Augustinian friary of Möðruvellir, in the north-east of Iceland. The evidence of this entry would seem to corroborate this claim; the entry seems quite clearly written from the point of view of someone from Eyjafjörður. At any rate, the narrative evidence from this entry suggests much more than the 'data without cosmetics', and indeed, it tells us more even than the annalist was biased in favour of the people of Eyjafjörður. The narrative coupling of these two events, the conflict between bishop Jón and Porsteinn Hallsson and the battle at Grund, suggests that the two events were perceived as being connected; or at least that the people of Eyjafjörour saw a link between them. This conclusion is strengthened by the fact that another annal written in the north of Iceland shortly after 1361, Lögmannsannáll, presents a similar coupling of the two events. ${ }^{116}$

These conclusions should not be overstated. Most annal entries are not so tightly structured. Even those that do veer into narrative form often veer quickly back into lists of events, and it would be unwise in many cases to seek too strictly for meaning in the juxtaposition of seemingly unconnected events. At the same time, close analysis of the entries in which annalistic style is abandoned will reveal a great deal about what was important to the annalists, and how they viewed contemporary events. Since the annalists appear for the most part to be members of the same clerical elite as Einarr Hafliðason and the North Icelandic Benedictine School, their writings provide yet another perspective from within this small group of elite clerics.

${ }^{116}$ Lögmannsannáll, p. 278. 


\subsection{Documentary Sources}

The fourteenth century was the time in which a culture of bureaucratic writing was developed in Iceland. The number of extant documents increases dramatically over the course of the fourteenth century. There are almost no preserved documents from before 1300. Of the $c .1500$ original documents preserved from the period before 1540 , less than fifty date to 1370 or earlier. More than $50 \%$ of currently preserved documents date from the second half of the fifteenth century. Within the period of 1300-70, the number and quality of the extant documents increases significantly after 1350, and over half of the documents preserved from this period date from the period $1350-70 .{ }^{117}$ In addition to numbers, there is a noticeable difference in standardisation and consistency from the 1340s to 1370s. Although scholars such as Agnes Arnórsdóttir have pointed to the fourteenth century as the period in which Icelanders shifted from oral to written contracts, a comprehensive study of this process has yet to be undertaken. The rewarding field of literacy, the study of the growth of bureaucratic writing, has yet to be applied to the Icelandic context. ${ }^{118}$ In fact, while Nordic scholarship has begun to interest itself in bureaucratic writing and literacy in the Nordic countries, this too, is a very new field with much that remains unknown. ${ }^{119}$ In addition to the general lack of scholarship in this field, studies of written contracts and records in Iceland have tended to focus on a single type of document, especially the máldagar, and most recently marriage contracts. ${ }^{120} \mathrm{~A}$

\footnotetext{
${ }^{117}$ Guðvarður Már Gunnlaugsson, 'Manuscripts and Paleography’, p. 249. This figure comes in the context of a paleograpic survey, and does not include documents which exist in later registers or copies.

${ }^{118}$ Agnes Arnórsdóttir, 'Marriage Contracts in Medieval Iceland', in To Have and to Hold: Marrying and its Documentation in Western Christendom, 400-1600, ed. by Phillip L. Reynolds and John Witte, Jr. (Cambridge: Cambridge University Press, 2007), pp. 260-389 (p. 383). On bureaucratic writing and literacy, see Michael Clanchy, From Memory To Written Record: England 1066-1307, 2nd edition (Oxford: Blackwell, 1993).

${ }^{119}$ On Norwegian bureaucratic writing, see Nedkvitne, The Social Consequences of Literacy, and Jan Ragnar Hagland, Literacy i norsk seinmellomalder (Oslo: Novus, 2005); see also the recent volume, Along the Oral-Written Continuum: Types of Texts, Relations and their Implications ed. by Slavica Ranković, Leidulf Melve, and Else Mundal, Utrecht Studies in Medieval Literacy, 20 (Turnhout: Brepols, 2010). On bureaucratic writing in Finland, see Tuomas Heikkilä ed., Kirjallinen kulttuuri keskiajan Suomessa [Literate Culture in Medieval Finland]. Helsinki: Suomalaisen Kirjallisuuden Seura, 2010).

${ }^{120}$ On the máldagar, see Guðvarður Már Gunnlaugsson, ed., Reykjaholtsmáldagi (Reykholt: Snorrastofa, 2000); Magnús Stefansson, Staðir og staðamál, especially pp. 86-89; and
} 
consequence of this type of specialisation is that the fourteenth century, and the development of a tradition of legal writing in this period, has been neglected. There are simply not enough documents preserved from this period to sustain the study of a single type of document; moreover, in this early period of bureaucratic writing the connection between the different types of document and their writers is particularly significant.

There is, in fact, a marked correlation between the circle of elite clerics responsible for the writing of bishops' sagas, annals, and religious and secular literature in the fourteenth century, and those producing legal writing in this early period. To some extent, this may be simply the product of what has survived; there is relatively little documentation preserved from the diocese of Skálholt from before $c$. 1370, for example. At the same time, however, the connections between individuals named in documents as executors or witnesses and individuals named in the contemporary bishops' sagas and the annals are striking, and bear further study.

In Norway and Iceland, where Old Norse was the language of official records, the most common form of documentation was the vitnebrev, or witnessletter. This is in contrast to the legal tradition in Sweden and Denmark, where the charter, written in Latin, was the most common method of recording a transaction. ${ }^{121}$ In the vitnebrev, one or more people report that they were present as certain named people performed a juridical act, normally confirmed by handaband (the clasping of hands), and corroborate their evidence by attaching their seals to the document. The verbs in a vitnebrev are in the preterite form, and the people involved are named in the third person. Thus, the vitnebrev is not a charter; it is a description of a transaction which has previously taken place. In Icelandic vitnebrev, the date and place of the witnessed transaction is given in the preamble, whereas the date and place of the letter itself is given at the end of the document.

Norway and Iceland both had well-established legal traditions before the arrival of writing, and continued to use these legal traditions until the end of the Middle Ages. The vitnebrev represent, in the words of Hallvard Magerøy, a 'literary superconstruction'. Oral formulas and juridical symbols retained their importance,

Margaret Cormack, The Saints in Iceland: Their Veneration from the Conversion to 1400 (Bruxelles: Société des Bollandistes, 1994).

${ }^{121}$ Hallvard Magerøy, 'Diplomatics', p. 137. See also Nedkvitne, The Social Consequences of Literacy, pp. 94-103; Erik Kroman et al., 'Bref', KLNM, 2, cols 226-29; Jan Liedgren, 'Diplom', KLNM, 3, cols 80-82; and Lars Hamre et al., 'Vitnebrev', KLNM, 20, cols 214-22. 
and the written documents worked to supplement rather than supplant the oral contract, or, in the words of Arnved Nedkvitne, 'the demands of orality and literacy were satisfied at the same time'. ${ }^{122}$

In Icelandic historiography, the closest thing to a study of literacy in society has been Agnes Arnórsdóttir's study of marriage contracts. She details the changing language of the contracts themselves, looking at evidence such as the shift from a third-person preterite record of a previous oral contract, to a first-person present tense, indicating that the document itself enacted the contract. ${ }^{123}$ Research into the history of literacy and written records, however, is still at a very early stage, and much is still unclear.

\subsection{Authorship and the Intellectual Milieu}

In this chapter, I have discussed different kinds of contemporary sources, sagas, annals, and documents as separate genres of writing. At the same time, it should be clear that most of the writing which has been preserved from the early to midfourteenth century was produced by the same very small group of individuals. As Michael Clanchy writes:

The experience of medieval writers and makers of records cuts across the lines dividing knowledge which scholars draw today. Although writers became gradually more specialized as the demand for documents increased, in the twelfth century and earlier they tended to perform a variety of functions. One of Thomas Becket's biographers, William Fitz Stephen, describes how he was a draftsman in his chancery, a subdeacon in his chapel, a reader in his law court, and on occasions a judge. ${ }^{124}$

The same was true of Icelandic clerics in the fourteenth century. By far the most obvious example in fourteenth-century Iceland is Einarr Hafliðason. In addition to Lárentíus saga, Einarr wrote a significant portion of Lögmannsannáll, and in fact, wrote the annal in his own hand. In total, five documents have been identified as

\footnotetext{
${ }^{122}$ Nedkvitne, The Social Consequences of Literacy, p. 95; Magerøy, 'Diplomatics', p. 137.

${ }^{123}$ Agnes Arnórsdóttir, Property and Virginity, especially pp. 273-77. See also her shorter article, which focuses on the role of documentation, Agnes Arnórsdóttir, 'Marriage Contracts in Medieval Iceland'.

${ }^{124}$ Clanchy, From Memory to Written Record, p. 82
} 
having been written in his own hand. ${ }^{125}$ Others bear the mark of his influence; a land transfer document from 1385, for example, bears the note that Einarr 'dictated the above-described agreement' (firir sagdi fyrgreindu kaupi). ${ }^{126}$ Einarr was one of the most frequent witnesses in the north of Iceland, appearing in over two dozen documents, including some of the oldest clear examples of witness-letters in Iceland. $^{127}$ In 1371, Einarr translated a miracle-story called Atburðr á Finnmörk from Latin into Icelandic, at the request of two friars of Möðruvellir named Björn and Snorri. ${ }^{128}$

Einarr's writing thus touched on every category I have discussed here: bishops' saga, annals, documents, and exempla, as well as drafting or copying. Although his is a particularly noticeable example, it is by no means the only one. Jón Halldórsson and Bergr Sokkason wrote romances. Björn Brynjólfsson wrote part of Reykjarfjarðarbók, the manuscript containing Árna saga. His father, Brynjólfr Bjarnason, appears in two of the earliest Icelandic witness-letters, dated to 3August 1340 and 30 April 1341, respectively, while Björn can be found witnessing a number of documents together with Einarr Hafliðason. Einarr Gilsson, who contributed verses to Guðmundar saga $D$, is named in three of the earliest witness-letters, and also witnessed several letters together with Einarr Hafliðason. The literary production of the fourteenth century was composed by a small and deeply interconnected group of elite clerics and laypeople; no study of the Church in this period can be conducted without thinking hard about the constraints which this places on what can be known about the period. At the same time, the concentration of writing in the hands of a very small group makes it both possible and necessary to make use of the range of written products of this period. By making use of the full range of written sources, I will have access to a range of perspectives; all still closely connected by their writers' personal relationships to each other, but differing as a result of genre, purpose, and specific audience.

\footnotetext{
${ }^{125}$ Stefán Karlsson, ed., Islandske Originaldiplomer indtil 1450 (Copenhagen: Munksgaard, 1963), pp. xxxix, and documents nos. 15, 24, 26, 27, and 39; see also Guðrún Ása Grímsdóttir, 'Formáli', in Biskupa Sögur, III, p. lxvii; and DI III, pp. 64, 72.

${ }^{126}$ DI III, pp. 382-84.

${ }^{127}$ DI II, pp. 417, 484, 673, 674, 675, 746; DI III, pp. 55-56, 65, 71, 74, 76-77.

${ }_{128}$ Alfræði Íslenzk: Islandsk Encyclopæedisk Litteratur, 2 vols, ed. by Kristian Kålund (Copenhagen: Samfund til udgivelse af gammel nordisk Litteratur, 1908-1918), I (1908), pp. 57-59.
} 


\subsection{Conclusion}

In this chapter, I have surveyed the sources for the study of the fourteenth century Icelandic Church. Critical approaches to these sources have been lacking, as criticism has been focused instead on the need to interpret the Íslendingasögur and other sources which describe the distant past. What is remarkable about fourteenthcentury historical and bureaucratic writing (bishops' sagas, annals, and documents) is in fact their closeness to their subject matter. Fourteenth-century bishops' sagas, annals and especially documentary writing describe events and individuals within the living memory of their authors, and in some cases, describe the authors themselves. As such, they provide remarkable insight into contemporary perceptions of the purpose and process of history writing, as well as clerical perceptions of authorship and personal connections to the subject matter of historical works. A reassessment of fourteenth-century narrative and non-narrative sources thus provides compelling evidence for a new literary history of Iceland, one that also has a place for historical approaches, conceptions of authorship, and the incorporation of documentary material.

A close-knit circle of clerical and monastic individuals produced the vast majority of the available sources. These individuals produced not only the historical and administrative material which has been the primary focus of this chapter (bishops' sagas, annals, and documents) but also exemplary, fantastic, and chivalric literature, as well as saints' lives, religious poetry, and compilations of earlier material. This concentration of literary production in the hands of a small group of individuals is crucial to the study of literary production in the fourteenth century, as well as for the study of the sub-episcopal elite which will be the focus of further chapters. The same small group of elites who controlled literary production also made up a large portion of the administrative elites: clerics who held administrative positions as diocesan officers, or simply as benefice-holders. As I will be describing in the following chapters, writing and administration were closely tied: in particular, the development of the diocesan officers and the importance of these positions can be closely linked to the annalistic and saga writing which highlights the role of these officials. 


\section{Chapter Three}

\section{Structure of the Icelandic Church}

In the last chapter I surveyed the relevant sources for the study of the Church in fourteenth-century Iceland and began to lay out some themes for what follows, including the importance of tightly-knit social networks to the Icelandic Church in the late Middle Ages, and the dominance of a small, interconnected group of elite clerics in the literary production of the period. In what follows, I examine the structure of the Icelandic Church, at the parish level and the episcopal level, as well as connections to the metropolitan in Niðarós, in Norway. This chapter is thus focused on institutional aspects of the Church: the hierarchies, laws, and mechanisms that, at least in theory, existed independently of the individual members of the clergy who made up the Icelandic Church. As I will discuss, however, the institutions of the Church in Iceland could never be entirely separated from the individual members of the clergy who enforced the rules that suited them, promoted the development of offices which allowed them the greatest amount of personal advancement, and used the structures of the Church to create and enforce an elite, exclusive identity.

There has not yet been a detailed survey of this kind for the fourteenthcentury Icelandic Church. This is, therefore, an important step in understanding the Church after the developments of staðamál (1269-97) and Bishop Árni’s New Church Law (1275). ${ }^{1}$ As such, this chapter provides new insights into the history of the late medieval Church, and will underpin the more detailed analysis of elite clerical identity in subsequent chapters. The survey presented here is based in part on existing scholarship. Where this has proved insufficient, however, I have included case study analysis to augment existing understandings of the fourteenth-century Church. In particular, my discussion of the development and importance of the diocesan officers in late medieval Iceland is based primarily on original research, as

\footnotetext{
${ }^{1}$ The best survey of the fourteenth-century Church is Magnús Stefánson's 'Frá goðakirkju til byskupskirkju'; this, however, is still more closely focused on the transitions of the late thirteenth century. An introductory survey is also provided in Gunnar F. Guðmundsson, 'Íslenskt samfélag og Rómakirkja', in Kristni á Íslandi, 4 vols, ed. by Hjalti Hugason et al. (Reykjavík: Althingi, 2000), II, pp. 1-188.
} 
the diocesan officers in the Icelandic Church have not yet been the focus of any dedicated study.

\subsection{The Icelandic Church}

Iceland was divided into two dioceses, Skálholt in the south and Hólar in the north. The first Icelandic bishop to be consecrated was Bishop Ísleifr Gizzurarson (10561080). Skálholt was his estate, and became the centre of the newly established Church in Iceland. It was Ísleifr's son Gizzur, the second Icelandic bishop (10821118), who gave the farm at Skálholt to the Church, making it the site of the first bishop's seat in Iceland. ${ }^{2}$ In 1106 Hólar was established to serve the Northern Quarter. The first bishop of Hólar was Jón Ögmundarson, an ordained chieftain from Breiðabólstaður í Fljótstdal (in the diocese of Skálholt). The story of the establishment of a see at Hólar, first told in Jóns saga helga, claimed that when Bishop Gizzur decided to establish a see in the north, none of the northern chieftains would give up any property for the maintenance of this new church. Finally, a priest named Illugi or Hilarius, who farmed at Hólar í Hjaltadal, gave up his own farm for the glory of the Church. ${ }^{3}$

The story of Illugi/Hilarius together with the history of its transmission provides an interesting case study of some of the issues most relevant to the fourteenth-century Church: continuity with the earliest history of the Icelandic Church, Latinity and intertextuality, and the heightened importance of the landholding clergy in Iceland. As an origin-story, the story of Illugi/Hilarius is telling, both of the rather haphazard nature of the foundation of the earliest Christian institutions, and of the ongoing tensions between the land-owning aristocracy and the Church. Orri Vésteinsson has emphasised the ways in which the earliest Christian institutions, far from being established with a sense of purpose, developed out of the landholdings of their founding patrons; Skálholt for instance, became the first bishopric in the south of Iceland not through deliberate choice from the ecclesiastical hierarchy, but because it was the estate owned by the first Icelandic

\footnotetext{
${ }^{2}$ Orri Vésteinsson, The Christianization of Iceland, p. 23.

${ }^{3}$ Jóns saga helga, Biskupa sögur, I, p. 195. The oldest text of Jóns saga helga was written shortly after 1200, and the two oldest redactions of the saga were written in the thirteenth century; Peter Foote, 'Formáli', in Biskupa sögur I: Fyrri hluti, p. ccxiv.
} 
bishop. ${ }^{4}$ The story of the establishment of a bishop's see at Hólar would also seem to reflect this early reality. Its continuing relevance in later centuries, on the other hand, probably lay more in its reflections on the land-holding aristocrats who refused to leave their ancestral land for the glory of the Church, and on the importance of the Church owning its own land. These were issues raised during the staðamál conflicts of 1269-97, and they remained current in the early fourteenth century.

The story of Illugi/Hilarius was known in the fourteenth century, appearing in Einarr Hafliðason's Lárentíus saga. Einarr introduces it as an account found in Jóns saga helga, an explicit form of intertextual referencing typical of the 'North Icelandic Benedictine School' of ecclesiastical writing in the mid-fourteenth century. ${ }^{5}$ In Lárentíus saga, Einarr claimed that Bishop Lárentius was descended from Illugi/Hilarius through his mother Porgríma Einarsdóttir; he also claimed that after Illugi gave up his farm at Hólar, he went to Breiðabólstaður í Vesturhópi (Einarr's own benefice), and was buried there. It is interesting that the two details apparently added to the story by Einarr himself (they do not appear in Jóns saga helga) serve to connect Bishop Lárentius and Einarr himself to the twelfth-century figure of Illugi/Hilarius. As Margaret Clunies Ross has shown, many thirteenthcentury Icelandic aristocrats claimed to be descended from saga characters; perhaps most famously, Jón Loftsson and the Mýrarmenn claimed descent from Egill Skallagrímsson, a claim preserved in Egils saga. ${ }^{6}$ More generally, scholars have investigated the many permutations of what Torfi Tulinius has called 'the chieftain class's endeavour to ground its identity in the past', including connections based on landmarks, allusion, and genealogy. ${ }^{7}$ While thirteenth-century chieftains sought to connect themselves to saga heroes such as Egill Skallagrímsson, Einarr's interest here is to connect himself and his patron Bishop Lárentius to a 'hero' of the early Christian church in Iceland. And in many ways, Illugi/Hilarius is a particularly fitting hero for a fourteenth-century cleric. He was a land-holding priest, and in giving up his land for the see, he displayed the Christian values of humility and

\footnotetext{
${ }^{4}$ Orri Vésteinsson, The Christianization of Iceland, p. 23. See also his discussion of the establishment of the early monasteries, pp. 135-41(see below, section 3.1.3).

${ }^{5}$ Lárentíus saga, p. 218; on the North Icelandic Benedictine School, see above, section 2.2.

${ }^{6}$ Margaret Clunies Ross, 'The Development of Old Norse Textual Worlds: Genealogical Structure as a Principle of Literary Organization in Early Iceland', Journal of English and Germanic Philology, 92 (1993), 372-85 (p. 382).

${ }^{7}$ Torfi H. Tulinius, 'Saga as a Myth: The Family Sagas and Social Reality in 13th-Century Iceland', 11th International Saga Conference, pp. 526-39 (p. 529).
} 
generosity, as well as a progressive (to a fourteenth-century clerical audience) interest in promoting the creation of an ecclesiastical administrative centre over familial nostalgia for his 'paternal inheritance' (föðurleifð; eignarjörð in Lárentíus saga). ${ }^{8}$ Finally, the insistence on his dual name, Illugi in Icelandic, and Hilarius in Latin, is reflective of the fourteenth-century clerical values of Latinity, and cultural contact with Europe. As I will discuss below, these themes of Latinity and cultural fluency, of valuing ecclesiastical administration and Church property, and of the importance of personal networks (understood not only as close personal connections, but as imagined communities of both living and historical figures) run through any discussion of the fourteenth-century Church.

\subsubsection{Parish Church Structure}

Around the year 1200, Bishop Páll of Skálholt counted 220 parish churches in his diocese. ${ }^{9}$ No similarly early count exists for the diocese of Hólar; the earliest count of parish churches in the diocese of Hólar (from the mid fifteenth-century) gives 109. ${ }^{10}$ Comparisons between Bishop Páll's register and later bishops' records suggest that the parish structure was established fairly early, and remained relatively constant throughout the Middle Ages, so these numbers can be applied fairly confidently to the fourteenth century. ${ }^{11}$ Moreover, Bishop Auðunn of Hólar's 1318 collection of máldagar contains records of ninty-eight churches, which is fairly consistent with the fifteenth-century count of $109 .{ }^{12}$

In addition to the approximately 329 parish churches in Iceland, there were up to a thousand lesser churches and chapels annexed to the parish churches. ${ }^{13}$ Dependent churches consisted of half-churches (with the obligation to perform half the masses of a full church), quarter churches (a quarter of the masses), and chapels

\footnotetext{
${ }^{8}$ Jóns saga helga, p. 195; Lárentíus saga, p. 218.

${ }^{9}$ The most comprehensive study of the register, as well as Páll's episcopate and saga (Páls saga) is Sveinbjörn Rafnsson, Páll Jónsson Skálholtsbiskup: Nokkrar athuganir á sögu hans og kirkjustjórn (Reykjavík: Sagnfræðistofnun Háskóla Íslands, 1993).

${ }^{10}$ Gunnar F. Guðmundsson, 'Íslenskt samfélag', p. 181.

${ }^{11}$ Orri Vésteinsson, The Christianization of Iceland, p. 93.

${ }^{12}$ DI II, pp. 425-87; see also Magnús Stefánsson, Staðir og Staðamál, p. 86.

${ }^{13}$ Gunnar F. Guðmundsson, 'Íslenskt samfélag', p. 181.
} 
(twelve masses a year). ${ }^{14}$ There were also some full churches which did not maintain a resident priest; these were also classed as dependent or annexe churches. ${ }^{15}$ Gunnar F. Guðmundsson has identified two main reasons for the prevalence of annexe churches in Iceland, namely the difficulties involved in getting to a distant parish church and the prestige for landowners involved in operating an annexe church on their farm. ${ }^{16}$ Benedikt Eypórsson has identified the presence of a large number of annexe churches as one of the markers of a 'church centre', which suggests that a large number of annexe churches could be a source of prestige to a parish church. ${ }^{17}$ An important exception to this understanding of the role of annexe churches must be the case of the more remote churches, which seem to have been expected to serve a large number of annexe churches with a minimum of clerics. For example, the single priest at Tjörn í Vatnsnes was responsible for a half church at Illugastaður, three chapels, and 24 masses which were to be sung in Saurbær, but Tjörn can hardly be called a church centre. ${ }^{18}$

Between 400 and 450 priests served these 330 churches, according to calculations by Magnús Stefánsson. ${ }^{19}$ This figure represents an average of 1.2-1.4 priests per parish church, which seems very low, if one considers that many of these parish churches also had annexe-churches to serve. R. N. Swanson, for example, estimated that three priests per parish was a minimum requirement of the parish system in late medieval England. ${ }^{20}$ However, England was a much more populous and wealthy country, with a far more sophisticated Church structure. It may well be an accurate description of the Icelandic parish system to say that a large number of

\footnotetext{
${ }^{14}$ Benedikt Eypórsson, 'History of the Icelandic Church 1100-1300: Status of Research', in Church Centres: Church Centres in Iceland from the 11th to the 13th Century and their Parallels in Other Countries, ed. by Helgi Porláksson, Snorrastofa rit, 2 (Reykholt: Snorrastofa, 2005), pp 5-71 (p. 60).

${ }^{15}$ Gunnar F. Guðmundsson, 'Íslenskt samfélag', p. 185.

${ }^{16}$ Gunnar F. Guðmundsson, 'Íslenskt samfélag', p. 186; see also Benedikt Eypórsson, 'History of the Icelandic Church', p. 63.

${ }^{17}$ Benedikt Eypórsson, 'Reykholt and Church Centres', in Church Centres, ed. by Helgi Porláksson, pp. 105-116 (p. 107).

${ }^{18}$ DI III, p. 169.

19 Magnús Stefánsson, 'Kirkjuvald eflist', in Saga Íslands: Samin að tilhlutan Pjóðhátíðarnefndar 1974, 5 vols, ed. by Sigurður Lindal (Reykjavík: Hið íslenzka bókmenntafélag, 1974-90), II (1975), pp. 55-144 (p. 80); see also Gunnar F. Guðmundsson, 'Íslenskt samfélag', p. 181. For a discussion of the situation in the twelfth century, see Helgi Skúli Kjartansson, 'Thin on the Ground: Legal Evidence of the Availability of Priests in 12th Century Iceland', in Church Centres in Iceland, pp. 95-102.

${ }^{20}$ R.N. Swanson, Church and Society in Late Medieval England (Oxford: Basil Blackwell, 1989), p. 30.
} 
annexe-churches were served by a minimum of priests. In the next chapter I will describe in more detail the careers, income, social status, and networks of the elite priests who held wealthy benefices; it is worth keeping in mind, however, that these clerics only represented a small fraction of the priests in the country, and served only a portion of the laity. Much remains unknown about local experiences of churchgoing and community in conjunction with parish church structure, and particularly the role of the numerous annexe churches: how parishioners made use of the chapels and other annexe-churches for devotional purposes in the absence of a permanent priest, and the role the parish churches and annexe churches played in the development or maintenance of local communities. Scholarship on Icelandic parish church structure has not yet focused on issues of community and piety, but future research in these areas will be strengthened by an understanding of clerical networks and elite clerical ideology in the later Middle Ages.

In the mid-fifteenth century, the half-churches became the focus of a controversy, known as the halfkirknamál (the half-church controversy) between Bishop Óláfr Rögnvaldsson of Hólar (1460-95) and the farmers of the Northern Quarter. The dispute centred around the obligations of farmers who maintained the half-churches to provide hospitality to the bishop on his yearly visitation tours. ${ }^{21}$ In the fourteenth century, the dependant churches do not seem to have been a source of concern for the bishops or the Church, even though they were operated by secular land-owners in contradiction of the ideal of ecclesiastical ownership of Church property. Moreover, the dependent churches only seldomly appear in accounts written by or about the beneficed elite clergy of this period. ${ }^{22}$ Their focus and mine is on the staðir and church centres which they held as benefices; it is worth bearing in mind, however, that these churches existed, and may have played a more important role in the religious life of remote communities, or wealthy landowners than they seem to have done for the elite clerical community.

Scholarship on parish church structure in Iceland has not yet attempted a comparison to parish church structures in other countries; comparisons to the Anglo-

${ }^{21}$ Gunnar F. Guðmundsson, 'Íslenskt samfélag', pp. 112-13; see also Lára Magnúsardóttir, Bannforing og kirkjuvald, pp. 181, 201-05 (with a focus on the connection between the halfchurch controversy and another case involving Bishop Óláfr, the Hvassafellsmál).

${ }^{22}$ In fourteenth-century sources, annexe churches feature in the máldagar (church inventories) and in deeds of sale between secular aristocrats; the deeds of sale almost always feature a detailed clause transferring the landowner's duties towards the church or churches on the property to the buyer; see for instance DI III, pp. 382-84. 
Saxon minster system or the Italian pievi (baptismal church) structure might be particularly fruitful, as these display many similar characteristics to the Icelandic parish church system. ${ }^{23}$ At the same time, the Icelandic system reveals its local peculiarities; no other region appears to have developed a comparable system of graduated annexe-churches (half- , quarter-, etc), for instance, the names of which appear connected to Icelandic legal terminology (see Chapter 1.2.2). This legalistic approach to annexe-churches in Iceland is a feature of the parish church system that would benefit from further study, and which may lead to a deeper understanding of the relationship between secular law codes and the development of Church structures in Iceland. Here too, comparative research might prove highly useful in highlighting the unique, as well as the canonical, features of Icelandic parish church structure.

\subsubsection{Tithes and Taxes}

The tithe was first introduced to Iceland in 1097 by Bishop Gizzur Ísleifsson, the second bishop of Iceland. The tithe was in four parts, one part to go to the church building, one part to the priest, one part to the bishop and one part for the maintenance of the poor. Iceland was unique in instituting a one-percent property tax rather than an income tax; Orri Vésteinsson has suggested that this was a necessity of Iceland's pastoral economy, which did not produce steady yearly incomes in the same way as primarily agrarian economies. ${ }^{24}$ The one percent property tax was intended to correspond approximately to ten percent of a yearly income, the Continental standard for the tithe.

The clergy was also subject to the tithe. According to the New Church Law, priests paid no tithe on service books, vestments, and other possessions required for providing religious service, but were required to tithe on all other possessions. ${ }^{25}$ The tithe in the New Church Law was fixed at six ells for a person who owned one hundred (tíutíu) ounces (equal to five hundráð, or 600 ells), and six further ells for

\footnotetext{
${ }^{23}$ This system of mother churches and dependent chapels was maintained in England and Italy much longer than other parts of Europe, into the eleventh and twelfth centuries. See Susan Reynolds, Kingdoms and Communities in Western Europe, 900-1300, 2nd ed. (Oxford: Oxford University Press, 1997), pp. 82-86.

${ }^{24}$ Orri Vésteinsson, The Christianization of Iceland, p. 70.

${ }^{25}$ Járnsíða og Kristinréttur Árna Porlákssonar, p. 161.
} 
every five hundráð (600 ells) after that. ${ }^{26}$ This comes out to $1 \%$ of owned property, the same tithe as prescribed for the laity.

Iceland was the first of the Scandinavian countries to organise a nationally recognised tithe. ${ }^{27}$ It has long been agreed that one of the main reasons why the tithe was accepted so early and so easily was that it benefited the Icelandic chieftains; a goð $i$ who owned the local church could claim two of the four quarters (the quarter for the church and the quarter for the priest). Local elites, moreover, also controlled the distribution of the paupers' quarter. ${ }^{28}$ The extent of the profit to be made from church tithes, however, has been debated. Gunnar F. Guðmundsson has argued that the income from tithes was in fact rather low. By his calculations, the average income for a church in tithes was seventy ells per year, while the highest income for a church in tithes was no more than 120 ells per annum (the equivalent of one hundred of vaðmál, or the value of one cow). ${ }^{29}$ Thus, the highest tithe received by any church was the equivalent of only 120 ells of vaðmál; not a vast sum for the secular chieftains, nor a large amount for the clerical elite holding the staðir in the fourteenth century.

Papal taxes, on the other hand, did not come to Iceland until after the submission to Norway in $1264 .{ }^{30}$ Peter's Pence, the papal tax on laypeople, was introduced to Norway and Sweden as early as 1152 by the papal legate Nicholas Breakspear; under English influence it had begun to be paid in Denmark as early as the beginning of the twelfth century. ${ }^{31}$ In Iceland, by contrast, there is no evidence that Icelandic farmers paid this tax until after the introduction of the New Church Law in $1275 .{ }^{32}$

The papal tithe was a tax on clerics and ecclesiastical institutions, instituted for a limited period of time. The first papal tithe to be levied on the Icelandic Church

\footnotetext{
${ }^{26}$ Járnsíða og Kristinréttur Árna Porlákssonar, p. 161.

${ }^{27}$ On the tithe in the Nordic countries, see Eljas Orrman, 'Church and Society', in The Cambridge History of Scandinavia, ed. by Helle, pp. 421-62 (pp. 453-55). See also Lars Hamre et al, 'Tiend', KLNM, 19, cols 280-300.

${ }^{28}$ Orri Vésteinsson, The Christianization of Iceland, pp. 67-75; Gunnar Karlsson, Iceland's 1100 Years, p. 40.

${ }^{29}$ Gunnar F. Guðmundsson,'Guði til pægðar eða höfðingjum í hag?: Níu aldir frá lögtöku tíundar á Íslandi', Ný Saga, 9 (1997), 57-64.

${ }^{30}$ Gunnar F. Guðmundsson, 'Rómaskattur og páfatíund', Ný Saga, 6 (1993), 4-15.

${ }^{31}$ Ibid., p. 4; Orrman, 'Church and Society', p. 431.

${ }^{32}$ Gunnar F. Guðmundsson, 'Rómaskattur og páfatíund', pp. 6-7.
} 
was the result of the Council of Lyons in $1274 .{ }^{33}$ This tithe was followed by several more. While other forms of papal taxation, such as the fructum beneficorum, were being collected from Norway at this time, there is no evidence that Icelandic clerics paid any taxes other than the intermittent Crusading taxes. ${ }^{34}$

\subsubsection{Staðir, Bandarkirkjur, and Major Churches}

In his influential monograph, Staðir og staðamál, Magnús Stefánsson laid out his theory of the structure of the Icelandic Church. Parish churches in Iceland, he argued, were legally divided into the categories of staðir or bandarkirkjur. A staðr was a church which owned enough of the farm to support a household; usually the entire home-farm, but sometimes a portion of it, if it was a particularly large estate. ${ }^{35}$ The bandarkirkjur (lit. farmers' churches) were churches which did not own the home-farm. Some of them owned a portion of the home-farm, dependent properties, or other holdings, such as right to usufruct on the property of the home-farm. ${ }^{36}$ The particularly important bandarkirkjur might in fact be quite wealthy; but without ownership of the home-farm, they fell into a different legal category. As a result of Bishop Árni's staðamál, the staðir came under the control of the bishop, but the baendarkirkjur remained in the control of the layperson who owned the farm on which they stood. ${ }^{37}$ The lay owners of the bandarkirkjur held a series of obligations towards the church on their property, and these were explicitly enumerated in records of property transaction throughout the fourteenth century. ${ }^{38}$ A final category of churches, in Magnús Stefánsson's account were the incorporated churches, parish

\footnotetext{
${ }^{33}$ For a discussion of the collection of this tax in the archdiocese of Niðarós, with an emphasis on Greenland, see Kirsten Seaver, The Frozen Echo; Greeland and the Exploration of North America ca A.D. 1000-1500 (Stanford, CA: Stanford University Press, 1996), pp. 71-76.

${ }^{34}$ On the increasing use of papal appointments and accompanying fees in the Norwegian Church in the mid-fourteenth century see Lars Hamre, 'To bergenske kyrkjehovdingar, bispebrørne Arne og Audfinn', in Kongsmenn og Krossmenn: Festskrift til Grethe Authén Blom, ed. by Steinar Supphellen (Trondheim: Tapir, 1992), pp. 139-65.

35 Magnús Stefánsson, Staðir og staðamál, p. 35; see also Orri Vésteinsson, The Christianization of Iceland, p. 125.

${ }^{36}$ Magnús Stefánsson, Staðir og staðamál, pp. 28-29; see also Orri Vésteinsson, The Christianization of Iceland, pp. 112-32.

${ }^{37}$ Magnús Stefánsson, 'Frá goðakirkju', p. 223.

${ }^{38}$ See for instance the sale of Ásgeirsá between Magnús Gizzurarson and Jón Hákonarson, DI III, pp. 382-84; see also Chapter 4.2.2.
} 
churches which had at some point become incorporated into the landholdings of the bishopric, or of a monastery. ${ }^{39}$ Only a small percentage of Icelandic parish churches were incorporated in this manner, and they do not figure into this discussion.

An important refinement of Magnús Stefánsson's division of churches into staðir and bandarkirkjur was developed in Church Centres in Iceland, a collection of related essays edited by Helgi Porláksson. ${ }^{40}$ The contributors to this book point out that while the division between staðir and baendarkirkjur is useful, it is not the only significant distinction to be noted when exploring the relative status of churches in Iceland. They propose an additional distinction between large, wealthy churches, termed 'church centres' or 'major churches', and smaller, less powerful churches with little or no influence outside of their own parish. ${ }^{41}$ In the big picture, it was still the case that the largest churches often tended to be staðir and the smallest, poorest churches often held the status of bandakirkjur. However, the essayists make clear that there are significant differences between the status of small and large staðir and small and large boendakirkjur as well as 'sometimes a thin, vague line between the status of a large staðr and a large baendakirkja, ${ }^{42}$ Benedikt Eypórsson, summarising the conclusions of the various contributors, proposed the following definition of a church centre: a church with a large ministry (tithes from sixteen or more farms), a large number of resident clerics (more than three), numerous annexe churches and a location on a main trade route. ${ }^{43}$ While this is an important contribution, this project's focus on the period 1100-1300 is limiting. By ignoring the fourteenth century, when the most important sources on parish church structure were written (such as the collections of máldagar), this project was unable to take into account local and variable factors, such as patronage, the development of parochial communities, and a number of other possible projects. An understanding of the relationships of patronage and dependency between the holders of major churches and the bishops who granted them, as well as studies of the networks of personal connection which linked the major churches to diocesan and archiepiscopal affairs

\footnotetext{
${ }^{39}$ Magnús Stefánsson, Staðir og staðamál, pp. 149-70.

${ }^{40}$ Helgi Porláksson, ed., Church Centres: Church Centres in Iceland from the 11th to the 13th Century and their Parallels in Other Countries, Snorrastofa rit, 2 (Reykholt: Snorrastofa, 2005).

${ }^{41}$ See for instance Benedick Eybórsson, 'Reykholt and Church Centres', in Church Centres, pp. 105-116 (p. 106).

${ }^{42}$ Ibid., p. 106.

${ }^{43}$ Ibid., p. 106.
} 
would greatly enhance our understanding of the prestige and power of the major churches in Iceland. This is a project that can best be undertaken when fourteenthcentury sources are used to study the context in which they were produced, instead of being applied to a period two centuries earlier.

\subsubsection{Monasteries}

At the beginning of the fourteenth century there were six active monasteries in Iceland and two convents. ${ }^{44}$ The monasteries in Iceland have largely been studied only in their role as producers of literature, and as centres of learning and knowledge. ${ }^{45}$ Quite recently, however, interest has been paid to the social role of the monasteries, especially their role in providing medical care to the community, primarily centred on the recent excavations of Skriðuklaustur, a fifteenth-century monastery in the East Fjords, where excavations have revealed evidence of hospital facilities for the community. ${ }^{46}$ Recently, Gunnar Karlsson and Helgi Porláksson conducted studies of the foundation of Pingeyri, the oldest monastery in Iceland, founded in $1133 .^{47}$

Most of the Icelandic monasteries were founded in the course of the twelfth century. Pingeyri, a Benedictine monastery in the north-west of Iceland, was the first to be founded, in 1133. It was followed by Munkapverá, also a Benedictine house, which was located in the north-east of Iceland, and founded in 1155. Pykkvibær was the first monastery to be founded in the south of Iceland; it was an Augustinian

\footnotetext{
${ }^{44}$ There have been few major studies of the monasteries in Iceland, and these are either out of date or inadequate. Janus Jónsson, 'Um klaustrin á Íslandi', Tímarit Hins íslenzka bókmenntafélags, 8 (1887), 174-265; on the convents, Anna Sigurðardóttir, Allt hafði annan róm áður í páfadóm: Nunnuklaustrin tvö á Íslandi á miðöldum og brot úr kristnisögu (Reykjavík: Kvennusögusafn Íslands, 1988).

45 See for instance Kirsten Wolf, 'Female Scribes at Work? A Consideration of Kirkjubæjarbók (Codex AM 429 12mo)', in Beatus Vir: Early English and Norse Manuscript Studies in Memory of Phillip Pulsiano, ed. by A. N. Doane and Kirsten Wolf, Medieval and Renaissance Texts and Studies 319, (Tempe, AZ: Arizona Center for Medieval and Renaissance Studies, 2006), pp. 265-95.

46 Hrafnkell Lárusson and Steinunn Kristjánsdóttir, eds, Skriðuklaustur: Evrópskt miðaldaklaustur i Fljótsdal: Greinasafn (Skriðuklaustur: Gunnarsstofnun, 2008); on the medical role of the monastery see especially the article by Jón Ólafur Ísberg, 'Lækningar, spítalar og klaustur', pp. 121-32 of this volume. See also Steinunn Kristjánsdóttir, "'Svo á jörðu sem á himni”": Minningarbrot frá Skirðulaustri í Fljótsdal', Ritröð Guðfraeðistofununar, 29 (2009), 151-71.

47 Gunnar Karlsson, 'Stofnár Pingeyrarklausturs', Saga, 46 (2008), 159-167; Helgi Porláksson, 'Porgils á Pingeyrum: Um upphaf Pingeyrarklausturs', Saga, 46 (2008), 168-80.
} 
house, founded in 1168 by St Porlákr Porhallsson, the first prior of Pykkvibær and later bishop of Skálholt. Helgafell, in the Southern Quarter, was founded in 1185, and a year later, in 1186, the first convent, Kirkjubær was founded, located on an old church property not far from Pykkvibær.

An Augustinian house was established on the island of Viðey in the diocese of Skálholt in $1224 .^{48}$ In the last decade of the thirteenth century, Bishop Jörundr Porsteinsson established the convent of Reynistaður, located near Hólar, and the Augustinian house of Möðruvellir, in Eyjafjörður (1295 and 1297, respectively). Two other monasteries were no longer active by the fourteenth century: Hítardalur in the south (active from 1166 to $c$. 1240), and Saurbær in the north (active from 1203 to $c .1224)$.

It is difficult to arrive at accurate population figures for the monasteries in Iceland, but they must have been very small. The most famous evidence for population figures is the account of the plague year 1403, stating that 'Lord Rúnólfr of Pykkvibær died and six monks, but another six lived. Halldóra abbess of Kirkjubær died and seven nuns, but six lived after'. ${ }^{49}$ From this it has been suggested that the average population of a monastery was thirteen or less. Population figures drawn from other sources suggest that the monasteries were even smaller. An account in Lárentíus saga of the friary of Möðruvellir suggests that in the early decades of the fourteenth century it was home to only four friars; when Bishop Lárentius arrived to inspect the friary, two of its friars had been sent away to minister in the local area, while two had recently died. ${ }^{50}$ An annal entry from 1344 recorded that when the Augustinian friary at Viðey became Benedictine in 1344, six monks accepted the rule of St Benedict. ${ }^{51}$ Orri Vésteinsson has suggested that this is why so many Augustinian houses were established, as these had the largest likelihood to succeed in a country where the sparse population made large monastic communities

\footnotetext{
${ }^{48}$ The monastery at Viðey changed rules and became Benedictine in 1344, but it was returned to the Augustinian rule in 1352 by Bishop Gyrðr Ívarsson; Gottskálksannáll, pp. 352, 355; see also Guðrún Ása Grímsdóttir, 'Biskupsstóll í Skálholti', in Saga Biskupsstólanna Skálholt 950 ára 2006, Hólar 900 ára, ed. by Gunnar Kristjánsson et al., (Akureyri: Hólar, 2006), pp. 21-243 (p. 38).

49 'Obitus herra Runolfs af Pyckua bæ oc vi brædra. enn adrir vi lifdv eptir. Obitus Halldorv abbadisar j Kirkiu bre. ok vij systra. enn vi lifdv eptir’, Lögmannsannáll (Ný Annáll), p. 286.

${ }^{50}$ Lárentíus saga, pp. 355-56.

${ }^{51}$ Gottskálksannáll, p. 352.
} 
impossible. ${ }^{52}$ In spite of their small size, the monasteries in the fourteenth and fifteenth centuries became very wealthy; by the time of the Reformation, the nine monasteries owned an estimated $13 \%$ of all landholdings in Iceland. ${ }^{53}$ An interesting facet of the small size of the Icelandic monasteries is that economically and socially, the monasteries may have been structured much like the larger staðir, which maintained roughly similar numbers of clergy, albeit secular clergy. The monasteries were often referred to in documentary sources as staðir, as were the two cathedrals, and in Bishop Vilchin's máldagabók from 1397, inventories of Viðey, Helgafell, Kirkjubær, were included in máldagabakur along with inventories of the parish churches. ${ }^{54}$ However, a great deal more research is needed to understand the economic and social structure of the Icelandic monasteries.

It seems that many of the abbots and priors came from the same small pool of elite Icelandic clergy as the benefice holders. Orri Vésteinsson, discussing earlier centuries, writes that while 'incredibly little is known' of the abbots, 'all those who can [be connected with known families] are however clearly of aristocratic birth' ${ }^{55}$ The same is true of the fourteenth-century abbots; and in addition to family connections, many of them can be connected to powerful ecclesiastical patrons, and held an important place in the networks of patronage and ecclesiastical politics. There is no evidence to suggest that the abbots or priors of even the largest monasteries in Iceland ever came from Norway or abroad. However, there is evidence for connections between individual monastic institutions in Iceland and institutions in Norway. The Augustinian house of Möðruvellir, for example, had a connection with the Norwegian Augustinian house of Helgisetri in Niðarós, and may even have been its daughter-house. ${ }^{56}$ Moreover, in 1320, Grímr, the abbot of the Norwegian monastery of Hólm supported the abbot of Pingeyri (Benedictine) in that monastery's conflict with the bishops of Hólar. ${ }^{57}$ The relationships between Norwegian and Icelandic regular clergy remain poorly understood. While there are

\footnotetext{
${ }^{52}$ Orri Vésteinsson, The Christianization of Iceland, p. 141.

${ }^{53}$ Magnús Már Lárusson, 'Jordejendom: Island', $K L N M$, 7, cols 671-77. On sources of income and the social role of the monasteries in the years before the Reformation in Iceland, see Vilborg Auður Î́sleifsdóttir, Siðbreytingin á Íslandi, pp. 97-103.

${ }^{54}$ DI IV, pp. 110-11, 165-72, 238-39.

${ }^{55}$ Orri Vésteinsson, The Christianization of Iceland, p. 135.

${ }^{56}$ Guðrún Ása Grímsdóttir, Lárentíus saga, p. 367, no. 1; see also Lárentíus saga, pp. 367, 391-95. On the establishment of Helgisetri, see Orrman, 'Church and Society', p. 427.

${ }^{57}$ DI II, p. 494. Grímr was appointed bishop of Skálholt a year after writing this letter (see below, section 3.2.2.).
} 
some constraints from the nature of the surviving evidence, much more could be done to further our understanding of the institutional and personal monastic networks connecting Iceland to Norway, and the rest of the Christian world.

The abbots and priors of fourteenth-century monasteries were part of a network of elite clerics. Moreover, as the leaders of the largest ecclesiastical institutions outside of the two bishops' sees, the abbots played an important role in ecclesiastical administration. In the fifteenth century several abbots held the position of officialis of Skálholt (see Appendix 2). Moreover, the abbots of the most powerful monasteries (Pingeyri and Pykkvibær) had an important role to play as mediators and arbitrators in ecclesiastical judgements. In the 1327 Möðruvallamál, a conflict between Bishop Lárentius of Hólar and the friary of Möðruvellir, the two arbitrators chosen by the archbishop of Niðarós to settle the case were Bishop Jón Halldórsson of Skálholt, and Abbot Porlákr of Pykkvibær. ${ }^{58}$ In addition to their role as arbitrators, the abbots of the wealthiest monasteries also found themselves occasionally in conflict with the bishops of the diocese (see Chapter 4.5.2). In this thesis, I have largely focused on the relationships between members of the secular clergy. However, the methodologies I have applied here could also be fruitfully applied to the study of relationships between the secular and regular clergy, as well as to the role of the monasteries in the district, and with the secular aristocracy in the neighbourhood.

\subsubsection{Relations between the Two Bishoprics}

From 1106, there were two bishoprics in Iceland. Although the bishops' sagas record many instances of disagreement between the two bishops since the establishment of the see of Hólar, there was also a remarkable degree of cooperation between the two dioceses. According to Árna saga, when Jörundr Porsteinsson, bishop of Hólar, left Iceland for Norway in 1287 he wrote to Árni Porláksson, bishop of Skálholt, to notify his colleague that he would be out of the country. In the letter, he asked that Bishop Árni

ordain those people whom his provosts should send to him, and also bless the chrism and the oil if any were sent, and also purify the bigger churches if they should be

${ }^{58}$ Lárentíus saga, p. 400. 
desecrated, and the other things which pertain to the episcopal office, as well as dealing with any conflicts which might arise.

vígja pá menn sem prófastar hans kynni at senda til hans, svá ok krisma ok oleum ef send vóru, svá ok at hreinsa hinar stærri kirkjur er saurgaðar væri ok aðra pá hluti sem til byskupligs embættis heyra. ${ }^{59}$

Unfortunately no similar letters survive from other bishops. At the same time, there is evidence to suggest that the bishop of one diocese regularly performed episcopal functions in both in the absence of his colleague. Voyages to Norway were common for bishops (see below, Section 3.3), and absences from these voyages lasted from a few months to several years. The bishoprics could lie open for years after the death of the bishop; at these times, too, while the officialis performed the administrative duties, only a bishop could ordain priests, purify churches, and perform other sacred duties. Of these duties, however, the one that was most often noted was the ordination of priests. During Lárentius' journey to Norway to be consecrated as bishop in 1323, Bishop Jón Halldórsson arrived in Iceland, at which time he 'performed ordinations from both bishoprics'. ${ }^{60}$ An entry in Flateyjarannáll for 1393 recorded that 'the bishop of Hólar performed ordinations from the diocese of Skálholt ${ }^{9}{ }^{61}$ At that time there had been no bishop resident at Skálholt for almost two years.

The entry in Flateyjarannáll records the appointments of eight priests to eight different benefices made by the officialis of Skálholt, Porsteinn Snorrason. ${ }^{62}$ This suggests that while the bishops could perform important sacred duties in both dioceses, appointments and other administrative duties remained in the purview of the officialis and other diocesan officers. Bishop Jörundr's letter in Árna saga seems to suggest something similar, asking Bishop Árni to perform ordinations for the diocese of Hólar at the request of the provosts.

At the end of the century, there is some evidence that the most powerful priests held benefices and provostships in both dioceses. In 1394, the officialis of Skálholt Abbot Porsteinn Snorrason appointed Steinmóðr Porsteinsson, one of the

\footnotetext{
${ }^{59}$ Árna saga, p. 170.

60 'Gjörði hann vígslur af báðum byskupsdæmum', Lárentíus saga, p. 366.

61 'gerdi Hola byskup vigslur af Skalholltz byskups dæmi', Flateyjarannáll, p. 423.

${ }^{62}$ Flateyjarannáll, p. 423.
} 
most important priests in Hólar and the incumbent of Grenjaðastaðir, to the benefice of Garður. ${ }^{63}$ For 1392, Flateyjarannáll recorded that:

Síra Halldórr Loftsson sat at Heynes because he had rented the land earlier from Bishop Michael. And he kept his powers there in the south. He also had the provostship in Eyjafjörður and kept it all the time after Lord Bishop Jón granted it to him and even when he was abroad.

sat Síra Halldor Loptzson æ. Heynesi puiat hann hafdi leigt iordina fyrr af Micheli bysleupi. hellt hann ok voldum sinum sudr par. hafdi hann ok profastzdæmi vm Eyiafiord ok halldit pui alla stund sipan herra Jonn byskup veitti honum pat ok sua mepan hann var vtan. ${ }^{64}$

A few years before, the same annal noted that 'Síra Halldórr Loftsson came to Iceland and had received from Lord Michael the provostship between Botsár and Geirolfs_- ${ }^{65}$ He held provostships in the dioceses of Skálholt and Hólar, and rented land in the south, while at the same time owning considerable properties in the Northern Quarter. It was thus possible, and increasingly common for elite Icelandic priests to hold multiple benefices and offices in both dioceses.

Although Iceland had been divided into two dioceses since the establishment of the see of Hólar in 1106, these two examples are enough to suggest that there was a high degree of cooperation between the two dioceses, and that in some instances, the Icelandic Church functioned as an integrated unit, with the bishops of either diocese fulfilling spiritual duties throughout the country, when required to do so through absences. This conclusion, however, should not be overstated; as the evidence for the cooperation between bishop and officialis makes clear, the officiales retained control over the administration of their own diocese, and the distinctions between the two dioceses were always maintained.

${ }^{63}$ Flateyjarannáll, p. 423. See also Sveinn Nielsson, Prestatal og prófasta á Íslandi, 2nd edn (Reykjavík: Híð íslenzka bókmenntafélag, 1950), pp. 108, 303. Steinmóðr also held Fagranes from 1399 to his death, Prestatal og prófasta, p. 242 (DI III, pp. 529, 709), Hofsping (Hóf á Höfðaströnd) from 1395 (DI III, pp. 503, 528), Helgastaðir in Reykjadalur, p. 307 (DI III, p. 556), provost of the Skagafjörður district after 1394 and of Pingeyjarping, pp. 264, 319 (Gottskálksannáll, p. 368).

${ }^{64}$ Flateyjarannáll, p. 419.

65 'kom vt Síra Halldorr Loptzson $o k$ hafdi pegit af herra Michieli profastz dæmi milli Botzær ok Geirolfs-', Flateyjarannáll, p. 417. The annal contains a gap after Geirolfs. 


\subsection{Church Officials within Iceland}

Within each Icelandic diocese, there existed a small number of ecclesiastical offices, appointed by the bishop and responsible to him. The two most important positions at each bishop's seat were those of the officialis and the vicar-general (ráðsmaðr). Not based at the two bishop's seats were the provosts (profastar sing. proffastr), the bishops' representatives within individual districts. These three positions, provost, officialis, and ráðsmaðr, were the most important adminstrative roles held by subepiscopal elite priests in Iceland.

These diocesan officers (officialis, ráðsmaðr, and prófastar) were new developments of the late thirteenth and early fourteenth centuries and appear to have been brought in from Norway as part of an effort to bring Iceland in line with the Norwegian model. The officers all have continental counterparts, and with the exception of the ráðsmaðr (vicar-general), all have Latin names which indicate their origin outside of Iceland. Being characteristic of the late medieval Icelandic Church, as well as being closely comparable to diocesan officers in any other part of Christian Europe, Icelandic diocesan officers have been the subject of no sustained study, and have only received the most superficial mention in surveys of the Icelandic church, encyclopaedic entries, and similarly superficial studies (for specific examples, see the sections below).

However, the fact that Iceland was well-integrated into fourteenth-century ecclesiastical practice is not an intellectual dead-end, but rather is the beginning of a wide field of inquiry into the conjunction of ideal and praxis, and specifically the local application of institutional structures (see Chapter 1.1). In the case of the Icelandic diocesan officers, one particularly interesting element, which separates this office from their continental and English equivalents, is the remarkably high status of the holders of diocesan office. The officiales were two of the highest-ranking officials, secular and ecclesiastic, in all of Iceland. The ráðsmenn and provosts were also held in very high regard, and the offices were held by some of the wealthiest and most powerful clerics in the country. This is not to say that diocesan officers, especially the officialis, were not important ecclesiastical positions outside of Iceland; but they were not such high-status positions, nor were they such clear indicators of social status and future powers. In fact, in the early sixteenth century, 
when the power to appoint bishops was returned to Iceland, the majority of the Icelandic priests elected as bishop had previously been diocesan officers. ${ }^{66}$

In part, the high status of the diocesan officers can be accounted for by the relative simplicity of the structure of the Icelandic Church. In the absence of canonries, archdeaconries, or other benefices sine cure, these administrative positions, as the highest offices to which an Icelandic cleric could aspire, were of great significance as sources of power and advancement. However, this situation alone cannot entirely account for the high status of the diocesan officers. As I will argue in what follows, I believe that the earliest holders of these offices themselves shaped the office, and gave ecclesiastical administrative positions the power and significance they held by the end of the fourteenth century. Foremost among them was Einarr Hafliðason, whose writings provide us with some of the earliest and most persistent mention of the officialis and ráðsmaðr: two positions he himself held for over twenty-five years. ${ }^{67}$

\subsubsection{Officialis}

The officialis was the most powerful cleric in the diocese after the bishop. ${ }^{68}$ Indeed, of all the officials of Iceland, the officiales were inferior in rank only to the bishops, and of the secular officials, the hirdstjorri (governor) and the two lawmen (lögmenn). ${ }^{69}$

The function of the officialis, however, is slightly more problematic. The office seems to have been the result of a conflation of two ecclesiastic officers, the officialis, or judicial authority, and the vicar who governed the diocese sede vacante. There exists a certain ideological overlap between the two positions; in both instances, the officialis exists as the alter ego of the bishop, his vicar in

\footnotetext{
${ }^{66}$ See below, section 3.3.2 and Chapter 6.1.2.

${ }^{67}$ See Appendix 2, which lists in tablular form all the known officiales and rádsmenn of Skálholt and Hólar. Even Einarr's eulogist, Magnús Porhallsson (the author of Flateyjarannáll) was not entirely sure how long he had held these positions; the annal entry for his death left blank spaces for the number of years he had held these two positions, Flateyjarannáll, p. 420.

${ }^{68}$ On the officialis in Iceland, see Gunnar F. Guðmundsson, 'Íslenskt samfélag', pp. 140-41; Magnús Már Lárusson, 'Official: Island', KLNM, 12, col. 539; Magnús Stefánsson, 'Frá goðakirkju', pp. 163-64. For a discussion of the role of the officialis in the bishop's household in the context of the thirteenth-century bishops of Lincoln, see Michel Burger, 'Officiales and the Familiae of the Bishops of Lincoln, 1258-99', Journal of Medieval History, 16 (1990), 39-53.

${ }^{69}$ Gunnar F. Guðmundsson, ‘Íslenskt samfélag’, p. 141.
} 
administrative and legal matters. This confusion is not limited to Iceland; as David M. Smith has argued, the term officialis in twelfth- and thirteenth-century England covered both of these functions, and it is often unclear from English sources which meaning was intended by the use of the term officialis at this time, if contemporaries even made a clear distinction between the two. ${ }^{70}$

The more straightforward of the two primary functions of the officialis was to govern the diocese when the bishop was away or the see was vacant; the officialis sede vacante. References in the bishops' sagas or annals to the officialis point most clearly to this function of the role; judging only from bishops' sagas, indeed, one could think that this was the only function of the officialis. The role of the officialis, in this capacity, was temporary, and ended with the arrival of the new bishop, or the return of the old. In 1357, upon the arrival of the new bishop, Bishop Jón skalli Eiríksson, Porsteinn Hallsson, the officialis of the church of Hólar, 'laid in his hand the seal of official', thereby ceremonially relinquishing his office. ${ }^{71}$ This act was particularly significant, because only a few years later, Porsteinn and many other priests would reject Jón skalli's authority, calling him 'bishop of Greenlanders, not bishop of Hólar', and demanding to see written proof of his appointment as bishop. ${ }^{72}$ By laying in the bishop's hand the seal of official, Porsteinn recognised the legitimacy of the incoming bishop (at least according to Flateyjarannáll, the only annal to include this detail) whatever his later feelings might be. ${ }^{73}$ In a sense, the officialis sede vacante then acted as a kind of gatekeeper for the arriving bishop, conferring the symbolic acceptance of the people of Hólar by accepting the bishop's arrival through the relinquishing of his own power as officialis.

The office of the officialis sede vacante was temporally bound and the position existed only in the absence of the bishop; the officialis was appointed by the outgoing bishop, and relinquished his office upon the arrival of a new bishop or the return of the old. However, it is clear from documentary sources that the second

${ }^{70}$ David M. Smith, 'The Officialis of the Bishop in Twelfth- and Thirteenth-Century England: Problems of Terminology', in Medieval Ecclesiastical Studies in Honour of Dorothea M. Owen, ed. by M.J. Franklin and Christopher Harper-Bill, Studies in the History of Medieval Religion, 7 (Woodbridge: Boydell and Brewer, 1995), 201-220.

71 'lagdi Porsteinn Hallzson i hond honum officiolatus jnsigli', Flateyjarannáll, p. 406.

72 'kolludo peir hann Grænlendinga byskop en ecke Hola byskop', Lögmannsannáll, Brot af Skálholtsannáll, pp. 225.

${ }^{73}$ The annal does however go on to note ominously that Porsteinn had done this 'aan lærdra manna radi' [without the advice of learned people], setting the stage for the conflicts to come, Flateyjarannáll, p. 406. 
function of the officialis was a permanent position, one which the officialis continued to hold even in the presence of the bishop. The permanent officialis administered the diocese, oversaw the proper living of priests and provosts, and oversaw the collection of Peter's Pence, in conjunction with the provosts (see below, section 3.2.4). Perhaps most importantly, the officialis also had legal duties; he acted as a judge, or named others as judges in ecclesiastical cases. ${ }^{74}$ It is this legal function which most closely resembles the officialis in other parts of Europe. The officialis in England presided over the courts consistory as the chief legal officer in the diocese. ${ }^{75}$ While in other parts of Europe, the role of the officialis was exclusively a judicial one, and semi-independent from the authority of the bishop, in Iceland, this was not quite the case. The officiales certainly did judge cases, but their role was less clearly delineated, less independent, and their function broader.

\subsubsection{The Development of the Role of Officialis}

Magnús Már Lárusson argued that the position of officialis came to Iceland from Norway, particularly as a result of Archbishop Eilífr's 1327 statute, which stated that, 'all bishops in the archdiocese of Niðarós shall have, in the appropriate places, officiales for themselves as it says in the statute of Archbishop Jörundr, of blessed memory’. ${ }^{76}$ Magnús Már Lárusson claimed that the first recorded instance of the officialis in Iceland was in 1340, only a few years after the promulgation of Archbishop Eilífr's statute. ${ }^{77}$ However, as I will discuss below, this interpretation does not account for the evidence of Lárentíus saga.

The duty of the officiales according to Eilífr's statute was, 'to research and carry out those lawsuits which appertain to the power of the church'. ${ }^{78}$ The reference to lawsuits (málaferli) suggests that the position of the officialis was here understood

\footnotetext{
${ }^{74}$ Gunnar F. Guðmundsson, 'Íslenskt samfélag', p. 140.

${ }^{75}$ Burger, 'Officiales and the Familiae', p. 39.

76 'Biskupar allir i niðaross erkibiskupsdæmi skulo i tilheyriligum stoðum hafa ser officiales sua sem stendir i statuto mildrar aminningar jörundar erkibiskups', DI II, pp. 630-31; Magnús Már Lárusson, 'Official: Island', $K L N M, 12$, col. 539. See also Bishop Jörundr's original statute, which, although it does not contain the same claim, contains the first Norwegian reference to the officialis, DI II, p. 277. On the officialis in the Scandinavian countries, see Troels Dahlerup et al., 'Official', KLNM, 12, cols 528-39; and Gunnar F. Guðmundsson, 'Íslenskt samfélag', p. 140.

${ }^{77}$ Magnús Már Lárusson, 'Official: Island', KLNM, 12, col. 539.

78 'at rannsaka ok niðr setia malaferli pau sem kirknanna valldi heyra til', DI II, pp. 630-31.
} 
to refer to the second of the two functions outlined above, that of legal officer and judge; however, as described above, the function most commonly attested in saga and annalistic evidence was that of the officialis sede vacante. In documentary sources, the first Icelandic use of the word officialis is from 1340, in a deed of sale from the diocese of Skálholt. ${ }^{79}$ The document records a sale between the bishop, Jón Indriðason, and a layman, Bjarni Guttormsson, and is witnessed by Síra Sigmundr [Einarsson], officialis; Eyjólfr, ráðsmaðr; Síra Teitr Teitsson; and Síra Árni Barðarson. The earliest annal entries to mention the officialis likewise date from 1340-41. Sigmundr is the earliest officialis of Skálholt to be mentioned in the annals; in entries for 1340, two annals record that Sigmundr was made officialis at the death of Bishop Jón Indriðason. ${ }^{80}$ In 1341, at the death of Bishop Egill Eyjólfsson, Einar Hafliðason was made officialis, the first instance in the diocese of Hólar to be recorded in the annals. ${ }^{81}$

It is only in Lárentíus saga that the word officialis is used in reference to events earlier than the 1340s; indeed, the earliest mention of an officialis at Hólar is that of Halldórr Grímsson, who acted as officialis during a two-year absence of Bishop Jörundr's in $c$. 1270-72. ${ }^{82}$ While this event occurred before the birth of the saga's author, the second recorded officialis of Hólar, Porsteinn skarðsteinn Illugason was well-known to Einarr personally, who eulogised him upon his death in 1335, and succeeded him as incumbent of Breiðabólstaður í Vesturhópi. ${ }^{83}$ Porsteinn acted as officialis sede vacante on four separate occasions in Lárentíus saga, the earliest being at the death of Bishop Jörundr in 1313, and the last upon the death of Bishop Lárentius in 1332 (see Appendix 2).

Looking at the instances of the use of the word officialis in Icelandic sources in tabular form (Appendix 2, Table 9), we can see clearly that Lárentíus saga is the only contemporary source using the term to describe events before 1340 . The same table shows us that the first officiales to hold long-term office were Snorri kyngir Porleifsson, officialis of Skálholt in 1355, 1360-63, and 1366 to his death in 1379,

\footnotetext{
${ }^{79}$ DI II, p. 734; Dahlerup et al., 'Official' KLNM, 12, col. 536.

${ }^{80}$ Skálholtsannáll, p. 209; Gottskálksannáll, p. 351; see also Appendix 2.

${ }^{81}$ Skálholtsannáll, p. 209; Gottskálksannáll, pp. 351, 352. Lögmannsannáll does not use the word officialis, but the rather more elaborate vices in temboralibus et spiritualibus, p. 273; see also Appendix 2.

${ }^{82}$ Lárentíus saga, p. 232.

${ }^{83}$ Lögmannsannáll, pp. 271-72; less than two years before his death, Porsteinn resigned Breiðabólstaður to take up the benefice of Grenjaðastaðir, Lögmannsannáll, p. 271.
} 
and Einarr Hafliðason, officialis of Hólar in 1341, 1370, and 1375 to his retirement in 1393 (see Appendix 2). These two officials were also the first clearly permanent officiales; Snorri was described at his death as 'officialis of Skálholt' (officialis af Skalhollti) while Flateyjarannáll describes how in 1393, 'Bishop Pétr appointed Síra Jón Magnússon to the office of officialis in the spring, because Síra Einarr wanted then to give it up, ${ }^{84}$ Both of these are descriptions of permanent officiales who held their office until death or retirement; the first such examples in Iceland. Moreover, the dates of Snorri and Einarr's officialities match so closely that the most likely explanation is surely that the position of permanent officialis was developed during their time in office, or in the 1360s and 1370s. Einarr's accounts of officiales in the diocese of Hólar in Lárentíus saga, thus, can be seen as his own efforts to normalise this new office, by giving the name of officialis to the officials who governed the diocese sede vacante in the absence of the bishop at the beginning of the fourteenth century, Halldórr Grímsson and Porsteinn skarðsteinn Illugason. By using the term consistently and fluently in Lárentíus saga, Einarr was working to legitimise and stabilise the position he held for nearly twenty years.

\subsubsection{Ráðsmaðr}

The position of ráðsmaðr corresponded broadly to that of the vicar-general in continental Europe. ${ }^{85}$ While the officialis in most European dioceses headed the ecclesiastical courts, the vicars-general held administrative positions within the bishop's household, as the foremost representatives (vicars) of the bishop. The study of officials and vicars-general in continental Europe remains somewhat dominated by the debate over the origins of the two seperate offices. Paul Fournier and his followers argued that the position of official developed first, with the position of vicar-general being created out of it as a result of the growing complexities of the office. Following Edouard Fournier, another school argued that the two positions developed independently from each other, the position of officialis developing out of the growing complexities of the ecclesiastical legal system, and that of vicar-general

\footnotetext{
${ }^{84}$ Flateyjarannáll, p. 411, Lögmannsannáll, p. 281; 'Skipadi Petr byskup vm vorit sira Ioni Magnussyni officiolatus starf puiat sira Einar villdi pa af leggia', Flateyjarannáll, p. 420.

${ }^{85}$ The study of the role of the vicar-general in continental Europe remains heavily indebted to Edouard Fournier, L'Origine du vicaire-général et des autres membres de la curie diocésaine (Paris: Chez l'auteur, 1940).
} 
developing from the role of the procuratores generales, who represented the bishop when he was away or incapable due to infirmity. ${ }^{86}$

The vicar-general was responsible for the maintenance of the bishop's estates, and the management of the home-farm and livestock, and he oversaw the collection of rents and tithes, and was accountable for them. ${ }^{87}$ Evidence from the bishops' sagas emphasises the role of the ráðsmaðr in the maintenance of the bishop's seat, specifically maintaining the buildings, and overseeing the farm and labourers. Árna saga describes an incident taking place upon Bishop Árni's return to Skálholt after a visitation in 1270, shortly after his ordination as bishop. Upon his arrival, he discovered that the bishopric had become greatly run down, especially the buildings, and the roof of the church had fallen into decay. The author notes that 'Jón Skúmsson was then away, who had long been the ræðismaðr there' ${ }^{88}$ This suggests that building maintenance was the responsibility of the ráðsmaðr, at least in the absence of the bishop. In Lárentíus saga, the vicar-general is portrayed as a person whose main function was to act as an overseer in charge of the farm and the labourers. Bishop Lárentius' vicar-general, Skúli, described as an excellent ráðsmaðr, is portrayed as being interested in the farm above all things. His duties, as described in the saga, were entirely secular, and included responsibility for the slaughter of the bishopric's sheep in the fall. ${ }^{89}$ On his deathbed, Bishop Lárentius showed the gold and treasures which he had accumulated over his lifetime to Skúli the ráðsmaðr and Einarr Hafliðason the deacon. Skúli the ráðsmaðr, unimpressed by the beautiful treasures, reacts by remarking that, 'food and livestock would seem to me to be more necessary to the staðr [Hólar] ${ }^{90}$ Both Einarr the deacon and Bishop Lárentius disagreed with his assessment, preferring the money; the episode can be read as a platform for Einarr's views on the importance of decorating one's church

\footnotetext{
${ }^{86}$ Fournier, L'Origine du vicaire-général, especially pp. 289-352; Paul Fournier, Les Officialités au moyen âge. Étude sur l'organisation, la compétance et la procédure des tribunaux ecclésiastiques ordinaires en France de 1180 à 1328 (Aalen: Scientia, 1984), reprint. Originally published Paris: E. Plon et Cie, 1880. For a discussion of the debate in subsequent years, see David M. Smith, 'The Officialis of the Bishop', pp. 203-05.

${ }^{87}$ The ráðsmaðr is probably the least-studied of the three diocesan officers in Iceland. Gunnar F. Guðmundsson says of them only that their role was the care of temporal matters and they were required to swear an oath, 'Íslenskt samfélag', p. 141; Magnús Stefánsson does not include them in his account of the bishop's officials, 'Frá goðakirku', pp. 160-64.

88 'Var pá í brottu Jón Skúmsson er lengi hafði par ræðismaðr verit', Árna saga, p. 21.

${ }^{89}$ Lárentíus saga, p. 432.

90 'Parfari pætti mér staðnum matr ok kvikfé', Lárentíus saga, p. 437.
} 
through lavish spending. ${ }^{91}$ The emphasis placed by Skúli the ráðsmaðr on basic necessities (food and livestock), although not shared by the bishop and Einarr, reflected his duties as ráðsmaðr to see to the basic needs of the bishopric.

As discussed above, the term officialis was not used in Iceland before 1340, except in Einarr Hafliðason's Lárentíus saga, where it was used for individuals as early as 1290 . The same is not quite true for the term ráðsmaðr, which can also be found in Árna saga. In addition to the instance described above, Árna saga named Loftr Helgason, Bishop Árni's nephew, as ræðismaðr of Skálholt. The term ráðsmaðr or raðismaðr was also much older than the fourteenth-century diocesan officer; it was used in a secular context, where it is more commonly translated as 'advisor' or 'steward'. 92 However, the term was used infrequently in Árna saga; while Loftr Helgason was named over fifteen times in the saga, he was called rææðismaðr only once. ${ }^{93}$ Here too, it was Lárentíus saga and the fourteenth-century annals which normalised the title: Lárentíus saga used the term on four separate occasions to describe the role of Skúli, and also Hafliði Steinsson, the father of Einarr Hafliðason (see Appendix 2), while Lögmannsannáll, Gottskálksannáll, and Flateyjarannáll mention eleven separate ráðsmenn of Skálholt and Hólar for the period from 1340 (1360 in Skálholt) to 1411 (1398 in Hólar; see Appendix 2).

\subsubsection{Profastar}

The final office appointed by the bishop was that of the provosts. Very little research has been done on the medieval provosts in Iceland, and what exists is primarily in the form of survey works. ${ }^{94}$ Much remains unclear both about the development of the office of the provosts, and the social role of these diocesan officers.

\footnotetext{
${ }^{91}$ See Einarr's speech that follows Skúli's words as well as the bishop's, Lárentíus saga, p. 437.

${ }^{92}$ The Cleasby-Vigfusson Icelandic-English Dictionary defines ráðsmaðr as 'a manager, counsellor', with no mention of the diocesan office: Richard Cleasby and Gudbrand Vigfusson, An Icelandic-English Dictionary, 2nd edn by William A. Craigie (Oxford: Oxford University Press, 1957), s.v. ráðsmaðr. Moreover, at least half of the instances of the word ráðmaðr recorded in the The Dictionary of Old Norse Prose are in the context of advisors or cousellors, especially kings' councellors: Dictionary of Old Norse Prose, s.v. ráðsmaðr.

${ }_{93}^{93}$ Árna saga, p. 104.

${ }^{94}$ Foremost among these are Magnús Stefánsson Frá goðakirkju til biskupskirkju', p. 163; and Gunnar F. Guðmundsson, 'Íslenskt samfélag', p. 140.
} 
The provosts were officials appointed as the representatives of the bishop to a particular district. Magnús Stefánsson has suggested that the provosts corresponded geographically to the secular sýslumenn, while he compared the officialis to the secular lögmaðr or lawman, of which there were two, one for the north and one in the south of Iceland. ${ }^{95}$ The districts of the provosts corresponded to the secular districts (syslar); eight in the diocese of Skálholt, and four in the diocese of Hólar. As Magnús Stefánsson cautions, however, late medieval evidence shows that in practice there were not always twelve provosts in the country at any given time as districts could be divided, and individual officials could hold multiple provostships. ${ }^{96}$ The provosts acted as an intermediary between the bishop and the parish priests of their districts, as they were required to attend diocesan synods and report the bishops' decisions to the priests of their district. At the same time, they were responsible for the maintenance of Church law in their district, and were required to communicate the bishop's legal decisions to the parish priests. They were also responsible for the collection of Peter's Pence and papal tithes, the bishop's quarter of the tithe as well as other fines, tolls and fees owed to the Church. ${ }^{97}$ In this, their function seems most closely to resemble those of the rural deans in England, whose role was to provide local administration in matters such as patronage of benefices, and to promulgate and provide a mechanism to discuss episcopal decisions within their deanery. ${ }^{98}$ In contrast to the rural deans of England, however, the provosts of Iceland competed with no ecclesiastical officials but those at the diocesan level, and provostships were consequently much-coveted and influential positions.

The word prófastr is first found in a document which may date to 1265 , and a second document, Bishop Árni Porláksson's ordinance of c. 1269, clarified that the prófastr was the representative of the bishop. ${ }^{99}$ Neither of these documents, however, has been dated satisfactorily. ${ }^{100}$ The term prófastr begins to appear in narrative texts from the beginning of the fourteenth century, and it has been thought that the office

\footnotetext{
${ }^{95}$ Magnús Stefánsson, 'Frá goðakirkju til biskupskirkju’, p. 163.

${ }^{96}$ Ibid., p.163.

${ }^{97}$ Ibid., p. 163.

${ }^{98}$ Swanson, Church and Society, p. 2; see also A.H. Thompson, 'Diocesan Organisation in the Middle Ages: Archdeacons and Rural Deans', Proceedings of the British Academy, 29 (1943), 153-94.

${ }^{99}$ DI II, pp. 16, 58-61.

${ }^{100}$ Magnús Stefánsson, 'Frá goðakirkju til biskupskirkju', p. 160.
} 
was created around this time. ${ }^{101}$ Magnús Stefánsson, however, considered that the office of prófastr may have come to Iceland somewhat earlier, in the time of Bishop Árni Porláksson of Skálholt and Bishop Jörundr Porsteinsson of Hólar (or in the decades after 1262-64. ${ }^{102} \mathrm{He}$ suggested that the appointment of clerics to provostships was connected to the bishops' increased power over church property after staðamál, especially their new-found power to assign staðir to priests as benefices. Moreover, the increased power of the bishops to judge legal cases, and collect tithes and taxes, made it necessary to delegate the task of administering and maintaining the law and collecting taxes and fines; it is thus, in his view, unsurprising that these administrative positions developed in this time.

The diocesan officers developed in part as a result of the changes to the structure of the Icelandic Church after the victories of staðamál in 1269-97; moreover, their development can also be connected to the increasing connection between Iceland and Norway, and the Norwegian archbishopric's interest in bringing the Icelandic Church in line with canonical practice in the rest of Europe. At the same time, however, the role of the diocesan officers was promoted and developed by the elite Icelandic clergy, particularly those who held ecclesiastical office in its early years. Annal notices, written primarily by clerical authors, made increasingly frequent mention of the officiales and ráosmenn, while clerical narrative, primarily Lárentíus saga, normalised and familiarised the use of the terminology through exemplary stories about officiales and rádsmenn set in the diocese of Hólar at the beginning of the fourteenth century.

\subsection{Iceland and Niðarós}

Moving outwards from the internal organisation of the sees of Skálholt and Hólar, and the Icelandic Church, we now turn to the relationship of these sees to their archbishop. The relationship between the Icelandic sees and their metropolitan has often been viewed in the context of Iceland's relationship to Norway on a national level, particularly in the context of Iceland's submission to Norway in 1262-64. And indeed, the relationship between Niðarós and its suffragen sees remains a particularly

\footnotetext{
${ }^{101}$ Cleasby-Vigfusson, An Icelandic-English Dictionary, s.v. prófastr.

${ }^{102}$ Magnús Stefánsson, 'Frá goðakirkju til biskupskirkju', pp. 162-63.
} 
fraught issue in terms of modern nationalism more broadly, as the medieval archdiocese encompassed three modern nations (Iceland, Scotland and Norway) and two relatively separate dependencies (Greenland and the Faroe Islands). In Icelandic history, the fourteenth century has been seen as the 'Norwegian Age (Norska Öldin) for the close economic, cultural, and political connections between Iceland and Norway in this period. Later in this thesis, I will be discussing the close integration between the Icelandic clergy and Norwegian ecclesiastical culture.

The archbishopric of Niðarós was established in 1153. It encompassed five Norwegian dioceses: Bergen, Oslo, Stavanger, Hamar, and Niðarós itself. In addition, the metropolitan also comprised six dioceses in the Atlantic Islands: Skálholt, Hólar, the Faroe Islands, Orkney and Shetland, Greenland (Garðar), and the Hebrides (Sodor). ${ }^{103}$ The archbishop made a distinction between the Norwegian dioceses and the outlying ones, comparable to the distinction made by the secular government between 'innan lands' (inside the country) and 'skattlönd' (tributary countries, lit. tax-lands). ${ }^{104}$ At the bishops' synods, the bishops of the Norwegian dioceses were required to attend, while the bishops of outlying dioceses attended when they could. Moreover, the archbishop went on regular visitations of the Norwegian provinces; there is no record of an archbishop ever visiting the outlying provinces. ${ }^{105}$ The dioceses within the kingdom of Scotland maintained a higher degree of independence from Niðarós than their counterparts. With the support of the Scottish king, the bishops rarely travelled to Niðarós to receive consecration, for example, and in 1349 the bishop of Sodor was granted exemption from his duty to visit his metropolitan in Niðarós. ${ }^{106}$

Even the papacy confirmed this distinction between the Norwegian and North Atlantic dioceses, and the practical difficulties involved in regular visitations to the latter. Pope John XXI, writing to Archbishop Jón rauði in 1276, acquitted him from visiting Greenland, and the North Atlantic dioceses, writing 'many dioceses in this kingdom [Norway] and your province are far away across the sea, and are spread out

${ }^{103}$ For an overview of the development of the dioceses and the establishment of the archbishopric see Orrman, 'Church and Society', pp. 426-31.

104 Jón Viðar Sigurðsson, 'Chapter 3: The Norse Community', in The Norwegian Domination, ed. by Steinar Imsen, pp. 59-73 (p. 62).

${ }^{105}$ Jón Víðar Sigurðsson, 'Samskipti íslenskra biskupa við útlenda yfirboðara á öldum áður', in Saga Biskupsstólanna, ed. by Gunnar Kristjánsson et al., pp. 490-515 (p. 510).

${ }^{106}$ Hamre, 'Church and Clergy', in The Cambridge History of Scandinavia, ed by Helle, pp. 653-75 (p. 653). 
within their borders $[\ldots]$ and without the greatest expense for your church it would be difficult for you personally to visit all the parts of the above-mentioned dioceses' ${ }^{107}$ Almost a century later, in 1365, the papal nuncio Guido de Cruce wrote of the necessity of appointing a sub-collector to these islands, rather than going himself: 'as, in the province of Niðarós, there are bishoprics which are very remote and insular [...] and especially and explicitly the cities and dioceses of Skálholt and Hólar'. ${ }^{108}$

In Norway, the archbishops held quite a bit of power. The extent of an archbishop's control over their suffragen bishops was never clearly defined in canon law, and the extent of their powers varied from region to region and over time. In the early fourteenth century in particular, through the influence of the Avignon Papacy, the powers of many archbishops over their suffragens lessened as a result of direct papal intervention. This, however, was not the case in Iceland until after 1380, when the papacy began to appoint bishops to Iceland; even then, the archbishop remained, in the words of Jón Viðar Sigurðsson, 'without a doubt the most powerful politician of Norway in the period from 1319-1537'. ${ }^{109}$

The bishops of Skálholt and Hólar made frequent journeys to Norway, as well as maintaining regular communication through messengers and letters. As part of their oath of allegiance, the bishops swore to visit the archbishop once per year, either in person or through a messenger. ${ }^{110}$ The bishops did travel frequently to Norway, but the majority of their yearly visits must have been conducted by messengers. There are few mentions of messengers being sent out to Niðarós, and no surviving letters. ${ }^{111}$ In general, however, fourteenth-century bishops appear to have

\footnotetext{
107 'ac plures dioceses in regno ipso tuaque prouincia constitute per maris spatia adeo sint disperse, ac intra suos limites dilatat [...] et absque grauissimo ecclesie tue dispendio partes omnes predictarum personaliter uisitare diocesium difficile tibi foret', DN 6, no 37; see also DN 6, no 36.

108 'cum in nidrosiensi prouincia sint episcopatus nonnulli remoti et insulares. [...] et specialiter et expresse ciuitatibus et diocesibus scalotensi et holensi', DI III, p. 203.

109 'án efa voldugasti stjórnmálamaður Noregs á tímabílinu 1319-1537', Jón Víðar Sigurðsson, 'Samskipti íslenskra biskupa', p. 499.

${ }^{110}$ DI II, pp. 504-05, 506-07.

${ }^{111}$ One notable exception is the account in Lögmannsannáll of the failed mission of Síra Óláfr, the representative of Bishop Egill Eyjólfsson who missed the boat and was left in Iceland; the incident seems to have been recorded because of its unusual failure. Lögmannsannáll, p. 271. On the role of messengers and letters in communication with Niðarós, see also Jón Viðar Sigurðsson, 'Samskipti íslenskra biskupa', p. 511.
} 
carried out their responsibilities diligently and to have followed the regulations set out for them; it seems safe to assume that they did the same here.

The bishops' journeys to Norway are well-documented in the annals, although as Boulhosa has recently cautioned, frequency cannot be taken for comprehensiveness. ${ }^{112}$ Although the annals may not have recorded every return journey, those that are recorded suggest that the bishops travelled with some regularity to Norway. Bishop Gyrðr, for example, made two journeys to Norway in his ten years as Bishop of Skálholt (1350-60). ${ }^{113}$ Ormr Ásláksson made a notable four journeys to Norway in his fourteen years as bishop of Hólar (1342-56). ${ }^{114}$ Egill Eyjólfsson of Hólar (1332-41) on the other hand, made only two journeys in nine years, of which one was to be consecrated as bishop of Hólar. ${ }^{115}$ However, many of these journeys made by the bishops themselves were under special circumstances, and were probably not instances of the bishops' duty to make yearly visits to their metropolitan. Egill's first voyage, made in 1332, was to be ordained as bishop of Hólar, and his second voyage, in 1335 was in response to a summons from the archbishop regarding the issue of papal tithes. Gyrðr's two journeys to Norway were both in the context of an ongoing dispute with a monk named Eysteinn. ${ }^{116}$

A second role of the archbishop was to act as a court of appeal, and this too is reflected in the bishops' travels. In times of controversy, bishops made frequent trips to Norway. This custom began as early as the time of Bishop Guðmundr Arason (1203-37) who made frequent visits to Niðarós to garner support in his conflicts with the northern chieftains. ${ }^{117}$ Controversial bishops such as Árni Porláksson, Jón skalli Eiríksson and Ormr Ásláksson also found themselves making frequent visits to the metropolitan in order to obtain the support of the archbishop. In contemporary Icelandic writing, the archbishop was depicted as a wise and generous authority figure. In Chapter 5, I will discuss the depiction of the archbishop in bishops' sagas.

${ }^{112}$ Boulhosa, 'Of Fish and Ships', pp. 177-84, especially p. 178.

${ }^{113}$ Gotteskálksannáll, pp. 356 (1355), 357-58 (1359).

${ }^{114}$ Lögmannsannáll, pp. 274 (1345 and 1347), 276 (1349 and 1355). On Ormr's conflicts with the farmers of Hólar, see, for instance, Guðrún Ása Grímsdóttir, 'Formáli' in Biskupa Sögur, III, pp. 1xx-lxxxiii.

${ }_{115}$ Lögmannsannáll, pp. 270-72.

${ }^{116}$ Gotteskálksannáll, pp. 356-58. On Eysteinn's relationship with Bishop Gyror and his debated identification as the author of Lilja, see above, Chapter 2.3.5.

${ }^{117}$ But see Guðrún Ása Grímsdóttir, who argues that this was not an innovation on the part of Bishop Guðmundr, but rather had been asserted as the right of the archbishop for many years. Guðrún Ása Grímsdóttir, 'Um afskipti erkibiskupa af íslenzkum málefnum á 12. og 13. öld', Saga, 20 (1982), 28-62. 
Here, it is enough to note that Icelandic bishops were in regular contact with their metropolitan, and looked to the archbishop for issues such as arbitration in legal matters.

\subsubsection{Appointment of Bishops}

Historians in the early twentieth century viewed archiepiscopal appointments of Icelandic bishops negatively, as early examples of Norwegian supremacy over Iceland. There is no denying that the timing of the first archiepiscopal appointments lends itself to this kind of critique. From the consecration of the first bishop of Iceland in 1056 to the year 1238, the bishops in Iceland were chosen from within Iceland. ${ }^{118}$ In 1238, the dioceses of Skálholt and Hólar both lay vacant, and for the first time the bishops were appointed by the Archbishop of Niðarós. For the first time as well, the two bishops appointed to Icelandic sees were Norwegians: Sigvarðr Péttmársson (1238-68) to Skálholt and Bótolfr (1238-47) to Hólar.

Icelandic nationalist scholarship, led by Jón Jóhannesson, interpreted this event in two ways. Jón Jóhannesson saw the archbishop's intervention as a direct response to the disastrous episcopate of Bishop Guðmundr Arason (Hólar, 1203-37), who had been elected bishop through powerful lay influence. ${ }^{119}$ Secondly, he suggested that the Norwegian bishops were working to strengthen Norwegian control over Iceland by controlling the Icelandic Church. ${ }^{120}$ Recent scholarship, on the other hand, has emphasised the canonical and international context of archiepiscopal appointments of bishops after 1238. Magnús Stefánsson argued that bishops in Iceland identified primarily with the Church as an institution; in their conflicts with secular Icelandic aristocrats, the bishops were not attempting to strengthen Norwegian control over the Icelandic Church, rather they were attempting to defend libertas ecclesiae, the freedom of the Church in matters such as the defence of Church property, the collection of tithes, or the episcopal right to hospitality. ${ }^{121}$ More recently, Jón Viðar Sigurðsson has shown that the archiepiscopal appointments of bishops followed directly from the promulgation

\footnotetext{
${ }^{118}$ On the appointment of bishops in Iceland, see especially Jón Viðar Sigurðsson, 'Island og Nidaros', especially pp. 136-38.

${ }^{119}$ Jón Jóhannesson, Íslendinga saga, I, especially pp. 249-56.

${ }^{120}$ Ibid., pp. 54-56.

${ }^{121}$ Magnús Stefánsson, 'Frá goðakirkju til biskupskirkju', especially pp. 250-53.
} 
within Norway of the statutes of the Fourth Lateran Council in $1215 .{ }^{122}$ Following the procedure reiterated at the Fourth Lateran Council, bishops within the archdiocese began to be elected by their cathedral chapters, while the bishops of Garðar (Greenland), Faroe Islands, Skálholt and Hólar, dioceses which had no cathedral chapters, were appointed by the archbishop. ${ }^{123}$

Archiepiscopal appointments may have been canonical, but contemporary sources show a definite reluctance on the part of the Icelandic Church to cede control over the nomination of candidates. In the period from 1238-1341, Icelanders continued to send candidates to be ordained. Many of these were selected by the bishops, who continued the practice of training and naming their own successor. In Skálholt, this practice continued until 1320, and Árna saga provides a good example of the circumstances under which a new bishop might be nominated. Árni Porláksson had been running the see of Skálholt in the old age of his predecessor, Bishop Sigvarðr Péttmársson (1238-68). Upon the death of the bishop, Árni was sent by his diocese to Niðarós to be consecrated as Sigvarðr's successor. However, he was accepted by the archbishop only after the archiepiscopal candidate, a Norwegian canon named Porleifr, died before he could be ordained. ${ }^{124}$ Thus, we can see in Árna saga an account of two competing traditions: the customary tradition of the bishop choosing his own successor, and the canonical right of the archbishop to name the bishops of sees without cathedral chapters. It is, moreover, noteworthy that the Norwegian-born Sigvarðr, himself the first bishop of Skálholt to be appointed by the archbishop, nonetheless followed the customary tradition of naming his own successor. As his example shows, the 'Norwegian bishops' did not necessarily constitute a homogeneous group, nor did they necessarily support the archbishop's agendas once bishop. The custom of nominating as bishop the cleric who ran the diocese in the final years of his successor was recorded from the earliest days of the Church in Iceland. Hungrvaka and Porláks saga both record how Bishop Klængr Porsteinsson (Skálholt: 1152-76) asked Porlákr to run the diocese of Skálholt in his old age, and later selected Porlákr as his successor. ${ }^{125}$

\footnotetext{
122 Jón Viðar Sigurðsson, 'Samskipti íslenskra biskupa', pp. 504-05; he makes much the same point again in 'The Norse Community', p. 66.

${ }^{123}$ See also Jón Viðar Sigurðsson, 'Island og Nidaros'. For further discussion of the appointments of bishops, see below, section 3.2.3.

${ }^{124}$ Árna saga, p. 12. See also Guðrún Ása's note to the text, p. 12, no. 3.

${ }^{125}$ Hungrvaka, in Biskupa sögur, II, p. 40; Porláks saga A, in Biskupa sögur, II, pp. 61-62.
} 
Árni Porláksson's successor was his nephew and namesake Árni Helgason was consecrated four years after the death of his uncle. The long delay was the result of divisive conflicts between the archbishop and chapter. Árna saga does not include an account of the bishops' death, and so it is difficult to ascertain the appointment of his successor. However, Árni Helgason was named in Árna saga as a trusted follower of the bishop his uncle, and he was almost certainly nominated from within Iceland to be appointed bishop. ${ }^{126}$ At the death of Árni Helgason in 1320, an individual know as Síra Ormr Porsteinsson (otherwise unknown, but from context clearly an Icelandic priest) was 'chosen [...] to be bishop of Skáholt' according to Skálholtsannáll. ${ }^{127}$ Ormr left Iceland, but died the next year, at which point Grímr Skútason, abbot of Holm in Norway, was appointed and consecrated as bishop of Skálholt (see below, section 3.2.2). Ormr Porsteinsson was the last Icelandic candidate put forward from the diocese of Skálholt until the late fifteenth century, and the bishops of Skálholt no longer named their successors.

In the diocese of Hólar, the tradition lasted a few years longer. Lárentíus saga describes in some detail the deathbed arrangements made by Bishop Lárentius, who named as his successor the incumbent of Grenjaðastaðir, and his own former pupil, Egill Eyjólfsson (Bishop of Hólar from 1332-41). ${ }^{128}$ Here too, however, the tradition of bishops nominating their successors appears to have ended with the death of Bishop Egill in 1341. After his death, the Norwegian canon Ormr Ásláksson was appointed bishop of Hólar (see below, section 3.3.2). However, as this brief survey of the nomination and appointment of bishops from 1238-1341 suggests, the practice of appointing a bishop was never as straightforward as knowing who had the canonical right to make the appointment. Local factors such as tradition, local politics, and personality played a key role as well; even after 1341, when bishops came exclusively from positions in the Norwegian Church, these continued to affect their appointments, as well as their interactions with their diocese.

\footnotetext{
${ }^{126}$ Árna saga, p. 200.

127 'kiorinn Síra Ormr Porsteins son til byskups yfir Skalahollt ok for vtan', Skálholtsannáll, p. 205.

${ }^{128}$ Lárentíus saga, pp. 437-41; on Egill's career before becoming bishop, see Chapter 5.3.3.
} 


\subsubsection{Norwegian Bishops}

From 1238 to 1380 , the majority of the bishops of the two Icelandic dioceses came from Norway. As discussed above, the Icelandic tradition of a bishop naming his successor meant that bishops were well-known and trusted within the diocese before their consecration as bishop. These were often priests from within the Icelandic ecclesiastical system, and in many cases had experience managing the diocese in the old age or absence of their predecessor. The Icelandic bishops are mostly wellknown from bishops' sagas and other sources, and their family connections, ecclesiastical backgrounds, and careers have been well-documented. ${ }^{129}$ Less is known about the bishops who came to Iceland from Norwegian clerical backgrounds. These bishops came from high-ranking positions within the Norwegian Church. While they were well-qualified to become bishop, and came from the same elite positions as other bishops in Norway, there is little evidence that any of these bishops had been to Iceland before their consecration. ${ }^{130}$

Of the Norwegian bishops of Skálholt in the fourteenth century, the majority came from a monastic background. ${ }^{131}$ Grímr Skútuson, bishop of Skálholt for a few months in 1321 had been abbot of Holm in Niðarós. ${ }^{132}$ Jón Indríðason (1339-41) was abbot of Selja, an island monastery dedicated to St Sunniva, which had been the original location of the diocese of Bergen. ${ }^{133}$ A third bishop of Skálholt, Gyrðr Ívarsson (1350-60), was abbot of Jónskirkja, an Augustinian house in Bergen; he had previously been a regular canon of Helgisetri in Niðarós. ${ }^{134}$ The monastic influence over the episcopacy of Skálholt is completed by the two bishops from

\footnotetext{
${ }^{129}$ On the bishops from 1056-1300 see especially Orri Vésteinsson, The Christianization of Iceland, pp. 144-78, and 220-37.

${ }^{130}$ One possible exception is Jón Halldórsson, as Sean Hughes has recently argued that this Norwegian bishop may have had Icelandic parents, 'Klári saga as an Indigenous Romance', pp. 37-38. See below, Chapter 5.2.1.

131 The only Norwegian bishop of Skálholt for the period 1238-1320 was Sigvarðr Péttmársson (1238-68), formerly abbot of Selja. For Sigvarðr's background and career as bishop of Skálholt, see Jón Johannesson, Íslendinga saga, I, pp. 255-56.

${ }^{132}$ Skálholtsannáll, p. 205. Information on the backgrounds of all the bishops of Skálholt can be found in Guðrún Ása Grímsdóttir, 'Biskupsstóll í Skálholti', pp. 30-66.

${ }^{133}$ Skálholtsannáll, DI III, p. 721, DN VII, p. 156. The see at Selja was founded by King Óláfr kyrri in about 1070, but it was probably moved to Bergen within a decade or two; Birgit Sawyer and Peter Sawyer, 'Scandinavia enters Christian Europe', in The Cambridge History of Scandinavia, ed by Helle, pp. 147-59 (p. 155).

${ }^{134}$ Guðrún Ása Grímsdóttir, 'Biskupsstóll í Skálholti’, p. 38.
} 
monastic backgrounds: Jón Halldórsson (1322-39), who came from the Dominican friary in Bergen, and Jón Sigurðsson (1343-48), an Icelander and a monk, about whose background little is known. ${ }^{135}$ There were two non-monastic bishops of Skálholt, Pórarinn Sigurðsson (1362-64) and Oddgeirr Porsteinsson (1365-81); nothing is known of the background of Pórarinn, while Oddgeirr had been a canon of the Bergen cathedral. ${ }^{136}$

In addition to the preponderance of monastic bishops, a second tendency can be observed. There seems to have been a close connection between Skálholt and Bergen, as at least four of the bishops of Skálholt came from institutions in or around Bergen (Jón Halldórsson, Gyrðr Ívarsson, Jón Indríðason, and Oddgeirr Porsteinsson) while a fifth, Grímr Skútason, was ordained by the bishop of Bergen. ${ }^{137}$ Even the first Norwegian bishop of Skálholt Sigvarðr Péttmarsson (123868) came from an institution in the vicinity of Bergen; like Jón Indriðason, he had previously been abbot of Selja.

The backgrounds of the northern bishops are more diverse, and there are more Icelanders among them. For the period after 1300, only three bishops of Hólar came from positions within the Norwegian Church: Auðunn rauði Porbergsson (1313-22), Ormr Ásláksson (1342-56), and Jón skalli Eiríksson (1358-90). The Norwegian bishops of Hólar primarily came from cathedral chapters: Bishop Auðunn had been a canon of the cathedral of Niðarós, and Bishop Ormr had been a canon of the cathedral of Stavanger. ${ }^{138}$ As canon of Stavanger, Ormr also oversaw the collection of the papal tithe under the papal nuncio Pierre Gervais in c. $1333 .{ }^{139}$ Jón skalli had been bishop of Garðar (Greenland) for several years before his translation to the diocese of Hólar (ordained in 1343). Although nothing is known of his career before becoming bishop of Garðar, Jón may have remained in Niðarós while bishop of Garðar, acting as an absentee bishop in the service of the

\footnotetext{
${ }^{135}$ No contemporary sources seem to mention where he was a monk before becoming bishop. It seems likely that it was in Norway, however, as the annals mention his arrival in Iceland, but not his journey out to be consacrated. See Guðrún Ása Grímsdóttir, 'Biskupsstóll í Skálholti', p. 37.

${ }^{136}$ Guðrún Ása Grímsdóttir, 'Biskupsstóll í Skálholti’, p. 39.

${ }^{137}$ DI II, pp. 502-06.

${ }^{138}$ On the background of Bishop Auðunn, see Lárentíus saga, pp. 245, 296, 319-20. See also DN II, nos. 89, 94, DN 3, nos. 88, 90. On Ormr Ásláksson' career as canon of Stavanger, see DN IV, nos. 129, 145, 155, 156.

139 P.A. Munch, Pavelige Nuntiers Regnskabs- og Dagböger, førte under TiendeOpkraevrningen (Christiana: Brögger \& Christie, 1864), p. 96.
} 
archbishop. ${ }^{140}$ It is thus perhaps possible to discern a connection to the archbishopric in Niðarós; in addition to bishops Auðunn and Jón skalli, the Icelandic-born Bishop Lárentius Kalfsson (1324-31) spent a significant part of his early career in the employ of the archbishop of Niðarós. In this, the bishops of Hólar followed the lead of the first Norwegian to be appointed bishop of Hólar: Bótolfr (1338-47) was a regular canon from the Augustinian house of Helgisetri, in Niðarós. ${ }^{141}$

It is not surprising that there should be such a strong relationship between Skálholt and Bergen. This city was an important Hanseatic trading centre and specialised in trading skreið, dried fish imported from Iceland and the northern coast of Norway, and exported to Europe. As such, connections between Iceland and Bergen were particularly strong after $1300 .{ }^{142}$ What is remarkable, however, is that in ecclesiastical spheres a strong connection existed only between Skálholt and Bergen; the bishops of Hólar had a closer relationship with the archbishopric of Niðarós, and no particular connection to Bergen. In all, the backgrounds of the Norwegian clerics appointed as bishops in Iceland match well with what is known of the election of bishops to Norwegian sees. ${ }^{143}$ They came either from the chapter houses or the monasteries, and many of them came from positions of some power as abbots or influential canons.

As recent scholarship has emphasised, the bishops who came from Norwegian backgrounds did not represent a subtle source of Norwegian influence over Iceland, nor were they the irresponsible, arrogant foreign bishops painted by earlier scholarship. However, much remains unknown about these bishops, and particularly their motivation to take up positions as bishops in Iceland. There is no evidence of absenteeism throughout the fourteenth century, and the vast majority of the bishops in Iceland worked hard to maintain and improve their diocese. Moreover, as I will discuss in more detail in the following chapter, these bishops integrated quickly and completely into local networks of friendship and antagonism with the

\footnotetext{
${ }^{140}$ A witness-letter places him in Niðarós in August, 1346, DN II, no. 276.

${ }^{141}$ The second and only other foreign-born bishop of Hólar of the thirteenth century, Heinrekr Kársson (1247-60) was of an unknonwn background. The careers of both bishops are discussed by Jón Jóhannesson in Íslendinga saga, I, pp 253-56.

${ }^{142}$ The relationship between Iceland and Bergen has been described in Björn Porsteinsson and Guðrún Ása Grímsdóttir, 'Norska Öldin', pp. 174-77.

${ }^{143}$ Charles Joys, Biskup og Konge: Bispevalg i Norge 1000-1350 (Oslo: H. Aschehoug, 1948); on the Norwegian bishops in the middle of the fourteenth century, see also Lars Hamre, 'To bergenske kyrkjehovdingar'.
} 
elite Icelandic clerics. The question remains how they adapted so quickly to local conditions, and what motivated so many high-ranking Norwegian clerics to give up postions in monasteries and cathedral chapters to take up the position of bishop of a distant see.

\subsection{Conclusion}

In this chapter, I have surveyed ecclesiastical administration and the structures of the Icelandic Church. This chapter focuses closely on the ecclesiastical structures and administration after the changes of the second half of the thirteenth century, with an emphasis on how the Church adapted and developed from those changes. These developments included, for instance, the arrival of papal tithes and Peter's Pence, the growth of diocesan office, and the role of the Norwegian bishops after 1238. All of these developments served both to integrate the Icelandic Church more closely into international Church structures, while at the same time connecting the Icelandic Church firmly to its metropolitan in Niðarós.

Church structures in Iceland were affected not only by the interests of their metropolitan and by the efforts to bring the Icelandic Church in line with ecclesiastical practice abroad, but also by the needs and interests of individual agents. Many aspects of ecclesiastical structure although appearing institutionalised and impersonal, were, in fact, deeply affected by the individuals who promoted changes to particular Church structures. In this discussion, I have paid particular attention to the development of diocesan officers in Iceland (officialis, ráðsmaðr, and prófastar). I have argued that the increasing significance of these positions, while related to exterior factors such as the development of a beneficial system in Iceland and the growth of administrative positions in the secular government of Iceland, can also be closely linked to the early holders of these positions, most importantly Einarr Hafliðason and his followers. Through their writing, their use of titles and the stress they placed on diocesan officers in writing such as bishops' sagas, annals, and documents, they gave the positions of the diocesan officers the importance and prestige that they clearly enjoyed by the end of the fourteenth century. 
The archbishop's newly-enforced power to appoint the bishops of Skálholt and Hólar in the early thirteenth century had important consequences for the development of Icelandic ecclesiastical structures. Although some Icelandic bishops continued to nominate their own successors, these nominations were not always honoured, and by the first half of the fourteenth century, this practice too fell out of use. One consequence of this change was for the elite Icelandic clergy, who could no longer aspire to be appointed bishop, and focused instead on developing the powers of the diocesan officers, and of the beneficed clergy. Another consequence, however, was the arrival of a large number of bishops from careers in Norway. These bishops primarily came from positions of power within the Norwegian Church, such as abbots and cathedral canons, a pattern which is consistent with what is known of the appointment or election of bishops within Norway. However, much remains unknown about these remarkable clerics, particularly regarding their motivation to end their careers in far-away Iceland, and how they were able to adapt to social and ecclesiastical structures there. These questions will only be addressed, however, by acknowledging that the bishops of Iceland from Norwegian backgrounds were themselves also acting as individual agents, not as representatives of the Norwegian Church. 


\section{Chapter Four}

\section{Sub-Episcopal Elite Priests in Iceland}

In the last chapter, I discussed the structure of the Church in Iceland in the late Middle Ages. I touched on the consequences of staðamál reforms of the late thirteenth century, and suggested that the introduction of a beneficial system allowed for clerics to gain the status of householders by acquiring church farms (staðir) as benefices. In the following chapter, I will examine the evidence for this thesis in more detail, and illustrate the economic and social consequences for the small group of elite priests who benefited from this system. Elite identity in late medieval Iceland centred on wealth, particularly the acquisition of property, and service to the king of Norway. The clerical elite too, amassed growing amounts of wealth and landholdings over the course of the fourteenth century as the wealth of the stadir formed the basis of their personal power.

In the second portion of this chapter, I examine clerical social networks and identity. I have already suggested that clerical writers in the fourteenth century formed a small and cohesive group. Here, I will argue that this network of clerical writers was matched by a close-knit network of clerical administrators and elite benefice-holders. There is at any rate a good a priori basis for studying elite priests as a group: the author of Lárentíus saga had no problem with the concept of an elite group of priests, and the saga makes frequent reference to the mestháttar prestar (most powerful priests) of the diocese of Hólar. ${ }^{1}$ These mestháttar prestar formed the core of the sub-episcopal elite priests in Iceland. They held positions as diocesan officers, and they held the largest benefices, the major churches and large staðir. Moreover, they developed an important role in the governance of the diocese, in their capacity as advisors, allies, and supporters of the bishop. It was through this process of the creation and manipulation of personal networks that the sub-episcopal elite carved out an important place for themselves in the government and administration of the diocese.

\footnotetext{
${ }^{1}$ Lárentíus saga, pp. 321, 329, 330, et passim. Sometimes also 'mestháttar menn', p. 389; 'fremstir prestar', p. 401; and 'fremstu kennimenn', p. 393.
} 


\subsection{Staðir, Church Centres, and Benefices}

I have already discussed the technical definitions of staðir and bandarkirkjur, as well as the concepts of church centres (or major churches) and benefices in the Icelandic context. Here, I will briefly go over the numbers of staðir and major churches, to begin to get a sense of the numbers of priests in Iceland who might aspire to become the incumbent of a staðr or major church. Those priests holding a staðr might be seen as the equal of a secular householder (bóndi), while the holders of the major churches had control not only over the staðr itself, but also had influence beyond their parish. While some clerics owned property of their own, and others gained power as diocesan officers, the basis of clerical wealth and position was the staðr.

Using information from sagas, annals and records, Magnús Stefánsson attempted to determine the legal status of all the known parish churches in Iceland. By his calculations 31-33\% of all the churches in both bishoprics were staðir in 1300 , rising to $32-36 \%$ in 1400 and $39 \%$ in $1570 .{ }^{2}$ In absolute numbers, he counted 67-76 staðir and 142-156 bandarkirkjur in the diocese of Skálholt in 1300, with eight churches incorporated into the bishopric or one of the monasteries. ${ }^{3}$ In the diocese of Hólar in 1300, he counted fourty-one staðir and sixty-eight bandarkirkjur, with up to five churches which were either bandarkirkjur or incorporated. ${ }^{4}$ Although the number of staðir went up slightly from 1300-1400, the difference is not significant. Throughout the later Middle Ages roughly a third of Icelandic churches were staðir or, in real numbers, 108-17 out of roughly 350 parish churches.

Jón Viðar Sigurðsson, the first scholar to have attempted a list of major churches in Iceland, puts the number of major churches (storkirker) in Iceland in 1100 at thirty-three: twelve in Hólar and twenty-one in Skálholt. ${ }^{5}$ Included in this number are the nine monasteries and convents; without them, the total comes out to twenty-four major churches before 1300: eight major churches in Hólar, and sixteen

\footnotetext{
${ }^{2}$ Staðir og Staðamál, p. 147.

${ }^{3}$ Ibid., p. 142.

${ }^{4}$ Ibid., p. 146.

5 Jón Viðar Sigurðsson, 'Islandske storkirker før 1300', in Church Centres, ed. by Helgi Porláksson, pp, 161-70 (p. 160).
} 
in Skálholt. It is important to note that Jón Viðar's list of major churches is only a first attempt at a comprehensive list of the major churches in Iceland, and should not be taken as definitive. In a recent master's thesis, Sigríður Júlíusdóttir has compiled her own list of the major churches in Skálholt. Using the same criteria (numbers of resident clerics), she arrived at a total of twenty-eight major churches in Skálholt, twelve more than Jón Viðar Sigurðsson. ${ }^{6}$ It is somewhat outside the scope of my thesis to argue over the inclusion of one church or another into the category of 'major church'; I find the category useful as a guideline only. Moreover, my interest is in the careers of the elite clergy in Iceland, rather than in the development of major churches as an institution; many of the major churches identified as such through their máldagar (church inventories) do not factor into the history of the subepiscopal elite clergy. Partly this is due to the nature of the surviving evidence: there are for instance hardly any surviving documents from the elite clergy of the diocese of Skálholt from the period 1300-60. However, it also appears to be the case that a few of the biggest major churches: Grenjaðastaðir and Breiðabólstaður í Vesturhópi in the north, and Oddi and Breiðabólstaður í Fljótsdal in the south, took on an importance beyond even the status of 'major church' as benefices for powerful, ambitious clerics. It is with these symbolically important benefices that I have been primarily concerned.

As it is a useful guideline, however, I have included below Jón Viðar Sigurðsson's list of the major churches; I prefer it for being the shorter of the two, and for including both dioceses of Iceland. The major churches identified by Jón Viðar Sigurðsson for Skálholt and Hólar are listed in the tables below. ${ }^{7}$

Table 2. Major Churches in Skálholt

\begin{tabular}{|l|l|}
\hline NAME & STATUS \\
\hline & \\
\hline Vatnsfjörðr í Ísafirði & bandarkirkja \\
\hline Skarð í Skarðsströnd & bandarkirkja \\
\hline
\end{tabular}

\footnotetext{
${ }^{6}$ Sigríður Júlíusdóttir, 'The Major Churches in Iceland and Norway: A Study into the Major Churches in Skálholt and Bergen Diocese in the 11th to the 15th Centuries', (unpublished master's thesis, University of Bergen, 2006), pp. 36-37. While there are significant problems with this thesis, the table of major churches in Skálholt upon which this conclusion is drawn is good.

${ }^{7}$ This list is taken from Jón Viðar Sigurðsson, ‘Islandske storkirker før 1300’, p. 159.
} 


\begin{tabular}{|l|l|}
\hline Staður í Staðarsveit (Staður í Ölduhrygg) & staðr \\
\hline Stafholt í Stafholtstungur & staðr \\
\hline Gilsbakki í Hvítársíða & staðr \\
\hline Garðar í Akranesi & bandarkirkja \\
\hline Bær í Bæjarsveit & bandarkirkja \\
\hline Reykholt & baendarkirkja \\
\hline Haukadalur í Biskupstunga & bandarkirkja \\
\hline Oddi í Rangárvellir & staðr \\
\hline Breiðabólstaður í Fljótshlíð & staðr \\
\hline Svínafell í Hof & staðr \\
\hline Rauðalækur í Hof & staðr \\
\hline Valbjólfsstaður í Fljótshlíð & staðr \\
\hline Holt í Eyjavallasveit (Holt undir Eyjafjöllum). & staðr \\
\hline
\end{tabular}

Table 3. Major Churches in Hólar

\begin{tabular}{|l|l|}
\hline NAME & STATUS \\
\hline Grenjaðastaðir í Reykjadal & \\
\hline Breiðabólstaður í Vesturhóp & staðr \\
\hline Háls í Fnjóskadal & staðr \\
\hline Möðruvellir í Eyjafirði & staðr \\
\hline Vellir í Svarfaðadal & bandarkirkja \\
\hline Múli í Reykjadal & staðr \\
\hline Hrafnagil í Eyjafirði & staðr \\
\hline Saurbær í Eyjafirði & bandarkirkja \\
\hline
\end{tabular}

Thus, at any given time during the fourteenth century, less than thirty individuals could hold one of the major churches of Iceland. The number is actually less than that; out of twenty-six major churches in this list, seven were bandarkirkjur, churches under lay ownership. In many cases, this meant that the incumbent was not the householder; and so we are looking at less than twenty major churches which were also staðir, churches at which the incumbent was the householder. Thus, out of 
108-17 churches holding the legal status of staðr in 1300, only twenty or so could be considered major churches, with any kind of influence outside of their own parish. Thus, while 108 of the roughly 350 priests in Iceland could hold a staðr, only 20-30 of these held major churches, with significant incomes and wide influence. If we think as well that many priests held their benefices for thirty years or more (Einarr Hafliðason held Breiðabólstaður í Vesturhópi for forty-nine years, and he was not alone in his longevity), we begin to see how few opportunities there were for an individual priest to hold a very lucrative benefice.

Of course, holding a staðr was not the only position of importance for clerics in fourteenth-century Iceland. A number of clerics served at the bishoprics of Hólar and Skálholt, some of them rising to great prominence that way. Some clerics remained unattached to a benefice, travelling to Norway and abroad, or owning their own private lands. Still others took a route to power outside of the secular clergy, embarking instead on monastic careers. The staðir were, however, the most important source of income bestowed by the Church, and the most straightforward path to advancement.

\subsection{Elite Priests in Iceland during the Norwegian Age (1269-1400)}

The period 1269 to 1400 was one of development and growth for the Icelandic Church, particularly in wealth and landholdings. Over the course of a century and a half, the sub-episcopal elite underwent a similar transformation. The personal incomes of the wealthiest priests in Iceland increased steadily over this period, as did the reach of their legal, administrative, and social powers.

Although a lengthy period of time, the Norwegian Age can be divided roughly into three distinct periods for the elite clergy. The earliest benefice-holders were put in place during or after the staðamál conflicts of 1269-97, which created a

benefice system in Iceland. Evidence for this period is patchy, but it might be said that this early period was characterised by the effort to establish a stable beneficial system. The successors to this first generation of beneficed clergy, priests who came of age in the 1320 s and 1330 s, were the benefactors of this newly created stability. This was the cohort of Einarr Hafliðason and the 'North Icelandic Benedictine School', and it was by this group of clerics that much of the great fourteenth-century 
religious literature was produced; it can thus be said that it was this period, and this group of clerics, which defined, to a large extent, the identity of the clerical elite. Finally the third period, made up of clerics ordained in the 1360s and later, can be characterised by the great wealth and influence of the elite clergy. In this period, the lay aristocracy had begun to build up the huge landholdings which would characterise the fifteenth century. ${ }^{8}$ Among the clergy as well, figures such as Steinmóðr Porsteinsson, nicknamed 'inn ríki' (the rich), amassed fortunes made up not only of benefices and ecclesiastical offices, but also of vast private holdings. This division is of course very rough and should only be taken as a generalisation; moreover, as I will discuss below, constraints laid by the nature of the extant evidence may be working to overemphasise differences between the sub-episcopal elite at the beginning and end of the fourteenth century. At the same time, it is difficult to discount the sense of development; the sub-episcopal elite at the end of the century were more stable, wealthier, more powerful, and more established than their counterparts a century earlier.

\subsubsection{The Earliest Benefice-holders, and the Establishment of Benefices}

I have argued above that the legal and political changes of the staðamál period led to social changes in the priesthood; specifically that the establishment of a beneficial culture allowed for the creation of a landed class of elite priests. In this, I have followed Magnús Stefánsson's argument that the goal and result of staðamál was to create a beneficial system in Iceland. ${ }^{9}$ While these changes were drastic, it is unlikely that they took place as suddenly as might be thought. The political and legal transformations of the period 1264-97, although significant, have been somewhat over-stated by a scholarly literature which still overwhelmingly sees the end of the Commonwealth period (1262-64) as the 'fall of the Free State', the end of Icelandic independence and the death of that which is unique and interesting in Icelandic society. ${ }^{10}$ In reality, a close examination of the careers of the earliest benefice holders reveals inconsistencies which suggest a less clearly delineated transition from lay ownership of the staðir to a beneficial system.

\footnotetext{
${ }^{8}$ Jón Viðar Sigurðsson, ‘The Icelandic Aristocracy', especially pp. 162-65.

${ }^{9}$ Magnús Stefánsson, Staðir og Staðamál, p. 48 et passim.

${ }^{10}$ See Chapter 1.1.
} 
This is perhaps most clearly illustrated by the case of Pórarinn kaggi Egilsson (d. 1277), the first attested benefice-holder at Vellir í Svarfaðardal in the diocese of Hólar. Pórarinn is introduced in Lárentíus saga as Pórarinn, 'who held the staðr at Vellir í Svarfaðardal'. ${ }^{11} \mathrm{He}$ is depicted as the head of the household there; when his cousin Porgríma was having difficulty with her pregnancy, he invited her to Vellir and acted as her host there. This took place in 1267, suggesting that Pórarinn was, or was imagined to be, the incumbent at Vellir by that date. ${ }^{12}$ If Lárentíus saga is to be believed, Pórarinn was thus the incumbent of Vellir í Svarfaðardal at least two years before Bishop Árni Porláksson began fighting for ownership of the churches in 1269. This might be taken as an anachronism reflecting the situation at the time of writing rather than the 1260s. However, it could also be taken as evidence that the social transformation after staðamál was not as abrupt as modern interpretations sometimes imply. Orri Vésteinsson provided evidence to suggest that bishops in the early thirteenth century were already looking for ways to increase their control over ecclesiastical property. ${ }^{13}$ He discussed the case of Vellir í Svarfaðardal in particular, as there is evidence that Vellir was in the control of the bishop of Hólar as early as 1190. ${ }^{14}$ Magnús Stefánsson similarly argued that many of the staðir in the diocese of Skálholt were not in dispute during staðamál, including Breiðabólstaður í Fljótsdal, which had been in the control of the bishops of Skálholt since the time of Bishop Porlákr (1178-93). ${ }^{15}$ These properties, as Orri Vésteinsson made clear, were not benefices; control was most often handed over by the bishops to lay patrons, only occasionally to individuals who were priests. ${ }^{16}$ If certain staðir had been undisputedly under the control of the bishops since the end of the twelfth century, however, their transformation into benefices around the middle of the thirteenth century would have been relatively easy, and could well have pre-dated Árni Porláksson's arrival as bishop of Skálholt in 1269.

Pórarinn kaggi Egilsson was one of the numerous children of Egill Sölmundarson. Egill was the nephew of Snorri Sturluson, and after Snorri's death, he became the owner of Reykholt and leader of the Sturlungar family; a very powerful

\footnotetext{
11 'hver helt staðinn á Völlum í Svarfaðardal', Lárentíus saga, p. 217.

${ }^{12}$ Lárentíus saga, p. 227.

${ }^{13}$ Orri Vésteinsson, The Christianization of Iceland, p. 130-31.

${ }^{14}$ Ibid., pp. 122, 165-66.

${ }^{15}$ Magnús Stefánsson, Frá goðakirkju til biskupskirkju, p. 192.

${ }^{16}$ Orri Vésteinsson, The Christianization of Iceland, pp.130-31.
} 
position in thirteenth-century Iceland. ${ }^{17}$ As the son, even the younger son, of such a wealthy and powerful chieftain, Pórarinn's uncontested tenure as the incumbent of the benefice at Vellir may have been assisted considerably by his connections. Egill Sölmundarson was also ordained as a sub-deacon, and Orri Vésteinsson has argued that he was one of the very last of the secular chieftains to be ordained in the style of the earliest period of Christianity in Iceland. ${ }^{18}$ His son Pórarinn however, represented one of the earliest examples of the new land-holding clergy, if Lárentíus saga is to be believed in this case. Pórarinn's peaceful career suggests that the transition of individual staðir into benefices may have been smoother in cases where the new elite clergy was assisted by familial connections.

While some staðir, such as Vellir í Svarfaðardal in the north and Breiðabólstaður í Fljótsdal in the south, may have been transformed into benefices with relatively little difficulty, others were relinquished with more difficulty, becoming the focus of the staðamál conflict, which lasted over thirty years. The first named priest to be given a staðr as a benefice as part of the staðamál conflict was Porgrímr Magnússon, who received Hítardalur. Bishop Árni, according to his saga, first demanded that Hítardalur be given into his control at the Althing in 1270. Ketill Loftsson, the layman who held it, first refused to give it up, then reluctantly submitted to the bishop, complaining, 'that it was however not right'. ${ }^{19}$ Bishop Árni sent three men, Óláfr, the abbot of Helgafell, Runólfr Sigmundsson, the abbot of Pykkvibær and a close friend of the bishop, and the priest Porgrímr Magnússon to collect from Ketill, but they were unsuccessful. ${ }^{20}$ The next year, when Bishop Árni and Ketill came to a settlement in which the layman renounced all claim to the staðr, it was given to Porgrímr: 'then the priest Porgrímr Magnússon, he who had before received the staðr rightfully (canonice), received him [Ketill] and all his property on the next moving-days as had previously been determined'. ${ }^{21}$ Precisely what was meant by the statement that Porgrímr had previously received the staðr is unclear, but he may well have been given it in name but not in practice while Ketill refused to abandon his claim.

\footnotetext{
${ }^{17}$ Árna saga, p. 45; Orri Vésteinsson, The Christianization of Iceland, p. 236.

${ }^{18}$ Orri Vésteinsson, The Christianization of Iceland, pp. 190-92.

19 'en kallaði pat pó ekki rétt', Árna saga, p. 19.

${ }^{20}$ Árna saga, p. 19.

${ }^{21}$ Tók pá Porgrímr prestr Magnússon, sá er áđr hafði pegit staðinn canonice, við honum ok allri hans eign á næstum fardögum sem áor var skilt', Árna saga, p. 25.
} 
Part of the problem with assessing the difficulty of the transition to a beneficial system lies in the stark differences between the two bishops' sagas which are almost the only sources of information about this period. Hardly any documentary evidence survives from the period before 1350; as a result, Árna saga and Lárentíus saga are almost the only sources of information on staðamál, and its direct consequences. ${ }^{22}$ The assessment of the two sagas could hardly be more different, and it is difficult to know which account to favour. Árna saga focuses almost exclusively on activity in the diocese of Skálholt. The saga, however, breaks off after 1290, before the partial resolution of the staðamál conflict in 1297, and without showing the results of Bishop Árni's success. Árna saga, focusing on the controversial life of Bishop Árni Porláksson, emphasised the difficult struggle of Bishop Árni for control over the staðir. It wrote of priests being evicted from their benefices by angry farmers in 1277 , and of several decades of conflict, unresolved before the saga broke off after 1290 .

Lárentíus saga, on the other hand, focuses on the northern diocese, and covers the years 1267-1331, the precise period of staðamál and its immediate aftermath. However, Lárentíus saga was written many years after the fact, probably in the 1360s: a century after the events of staðamál. Its portrayal of the beneficial system at the turn of the thirteenth century is of a stable, fully-developed beneficial system with relatively few conflicts, and relatively little change. Whether this is a true reflection of the situation in the 1290s, or is rather an anachronistic (or fantastic) depiction of the period, is difficult to say.

Lárentíus saga gives evidence for a few other early benefice-holders, although some of the evidence is implicit rather than direct. The saga makes reference to Hafliði Steinsson, the father of its author Einarr, being the incumbent of Breiðabólstaður í Vesturhópi by $1309 .{ }^{23}$ At the death of Bishop Jörundr Porsteinsson in 1312, Koðrán Hranason was mentioned as incumbent of Grenjaðastaðir. ${ }^{24}$ An incident in 1307 involving a dispute over burial rights reveals that Hildibrandr Gormsson was priest of Bægisá at that time. ${ }^{25}$ Finally, when Lárentius was twentyfive (in 1288), Bishop Jörundr gave him the benefice (beneficium) of Háls in

\footnotetext{
${ }^{22}$ Although some documents surrounding the staðamál conflicts are extant, for example DI II, pp. 92-93.

${ }^{23}$ Lárentíus saga, p. 308.

${ }^{24}$ Ibid., p. 314.

${ }^{25}$ Ibid., p. 277.
} 
Fnjóskadalur. Lárentius stayed there one year, 'then he gave up the benefice (staðr) because he was unlucky with his livestock in his housekeeping ( $p v i$ at honum vildi litt til fjár í búnaðinum). ${ }^{26}$ Although his tenure is short-lived, the wording here suggests that Lárentius' failure was the result of bad farming, rather than institutional problems.

In spite of the late date of writing of Lárentíus saga, its depiction of a relatively untroubled transition into a beneficial system rings rather true. Árna saga's more turbulent account focuses very narrowly on a small number of contested benefices to highlight the bravery and successes of Bishop Árni Porláksson. Many of the uncontroversial benefices, such as Vellir í Svarfaðardal must have come under the control of the bishop in quieter ways, and their first incumbents must have been established with little opposition. However, Lárentíus saga's depiction of the earliest beneficial system as essentially unchanged over the next sixty years is somewhat less convincing. The earliest incumbents of the controversial staðir in the south faced decades of uncertainty, caught in the middle of a power struggle between the bishop and the lay owners of the staðir. Even the early incumbents of the uncontroversial staðir must have faced the difficult task of establishing themselves as householders under a new beneficial system. While they seem to have attempted as far as possible to maintain older traditions of land ownership and leadership, the tasks of establishing themselves and holding on to their benefices must have been much more difficult in this early period than for later generations.

\subsubsection{The Clerical Elite at the End of the Norwegian Age: A Case Study}

By the final decades of the fourteenth century, the clerical elite had changed drastically. The wealthiest priests were vastly wealthier, and held major manors and other properties in addition to drawing an income from their benefices. The importance of diocesan office had solidified by the end of the century; the wealthiest and most powerful clerics held positions of ráðsmaðr or officialis, and the importance of provostships was growing.

One problem with any comparison between the clerical elite in the 1390s and those of the 1300s consists of the difficulty in comparing different types of source

${ }^{26}$ Lárentíus saga, p. 232. 
material. The primary sources of information on the earliest generation of beneficed priests were the bishops' sagas. By the 1390s, documentary material had become more prevalent, but the writing of bishops' sagas had come to an end. Bearing in mind the difficulties involved in comparing information produced in different genres of writing, a few clear differences can still be seen.

At the turn of the fourteenth century, the three most powerful clerics in the diocese of Hólar were Pórðr Pórðarson, Steinmóðr Porsteinsson, and Halldórr Loftsson. All three died during the Great Plague of 1402-04, and all three were described as officialis of Hólar at their death. ${ }^{27}$ They had very different career paths: Pórðr had the closest personal links within the administration of Hólar, as the protégé and successor of Einarr Hafliðason, while Halldórr Loftsson's career is the most secular of the three, and he seems never even to have held a benefice of his own.

Pórðr Pórðarson had the longest known career of the three; the earliest record of him as a priest is from 1369, when he witnessed an oath as Pórðr Pórðarson, prestr (priest). ${ }^{28}$ Pórðr spent most of the following years holding the position of ráðsmaðr of Hólar while Einarr Hafliðason acted as officialis. He is unequivocally named as ráðsmaðr for the first time only in a record of a legal case from 1386, although his name regularly appears on witness lists between 1383 and 1392 directly after Einarr's, and it seems likely that he held the position of ráðsmaðr for a much longer time. ${ }^{29}$ Pórðr held the benefice of Höskuldsstaður í Skagaströnd, on the coast north of Skagafjörður. Höskuldsstaður was the first benefice of Einarr Hafliðason as well, which he left in 1341 to take up the benefice at Breiðabólstaður í Vesturhópi. Höskuldsstaður, though a staðr, was not one of the most lucrative benefices, and it has not been considered a major church. ${ }^{30}$ However, over the course of the fourteenth century, Höskuldsstaður had been the beneficiary of some significant donations. Some of these donations came from previous incumbents, Einarr Hafliðason and Marteinn Pjóðólfsson, but much of it can be ascribed to the aristocratic family of Benedikt Kolbeinsson. The family were generous religious

\footnotetext{
${ }^{27}$ Vatnsfjarðarannáll elzti, published in Annálar 1400-1800, III, p. 23; see also Appendix 2.

${ }^{28}$ DI III, p. 253.

${ }^{29}$ See Appendix 2, 'The officiales and ráðsmenn of Skálholt and Hólar'; the witness lists which name Einarr and Pórðr as first and second witness are: DI III, pp. 371-72 (November 1383); pp. 373-74 (May 1384); pp. 419-21 (January 1388); pp. 479-80 (April 1392).

${ }^{30}$ See above, section 4.1 .
} 
patrons. They had a particularly close connection to the recently established convent of Reynistaður in the north, as Benedikt's aunt Hallbera was the first abbess there, and his daughter, Ingibjörg became a nun bringing in a generous donation. But the family also generously patronised the church at Höskuldsstaður, their parish church. $^{31}$

In addition to his income from Höskuldsstaður, Pórðr built up his own personal holdings. His brother, Arngrímr Pórðarson, who died shortly before June 1392, left behind property totalling 480 hundráð and livestock totalling 115 kúgildi. ${ }^{32}$ Pórðr himself owned significantly more. In 1374, Pórðr purchased three shares in Geitaskarð and Bulungarnes in Langdalur for seventy hundráð. ${ }^{33}$ In 1387, he purchased Finnstaður í Skagaströnd for fifteen kúgildi and fifteen hundráð (equivalent to thirty hundráð). ${ }^{34}$ In November of 1402, only a year before his death, Pórðr sold the island of Ytri-Ey to his barnamóðr (the mother of his children) Valdís Helgadóttir for thirty kúgildi. Some years before, he had sold her the small island which lay between land, Ytri-Ey, and Valdís' own property of Syðri-Ey for ten kúgildi. ${ }^{35}$ In 1409, two witnesses testified that in the fall of the year that he had died, Pórðr Pórðarson had tithed 1200 hundráð. ${ }^{36}$

As Agnes Arnórsdóttir recently noted, wider studies are needed on property transfer in the later Middle Ages in Iceland; how much land was bought and sold, and by whom. ${ }^{37}$ Current studies on property in the late Middle Ages are limited to a few outstanding examples, and to calculations of the property holdings of the two bishoprics. ${ }^{38}$ Given the current state of research in this area, it is difficult to place the above information about Pórðr Pórðarson's holdings in context. It seems unlikely, for example, that the properties about which documentation has survived, detailed above, constituted the whole of Pórðr's landholdings. Without further research, however, it is difficult to speculate regarding the percentage of transactions

${ }^{31}$ DI III, pp. 170-71, 599-601. On the family connection to Reynistaður, see DI III, p. 185; DI II, pp. 735-36, 766-67; Lárentíus saga, p. 386. See also below, section 4.5.1.

${ }^{32}$ DI III, p. 481.

${ }^{33}$ DI III, pp. 378-79.

${ }^{34}$ DI III, p. 398.

${ }^{35}$ DI III, p. 677.

${ }^{36}$ DI III, p. 726.

${ }^{37}$ Agnes Arnórsdóttir, Property and Virginity, p. 61.

${ }^{38}$ See for example Gunnar F. Guðmundsson, 'İslenskt samfélag', p. 148; Björn Porsteinsson and Guðrún Ása Grímsdóttir, 'Norska öldin', pp. 89-92; Björn Teitsson and Magnús Stefánsson, 'Um rannsóknir á íslenzkri byggðarsögu tímabilsins fyrir 1700', Saga, 10 (1972), 134-78 (p. 162). 
documented in the written record. Moreover, it is difficult to place Pórðr's holdings in context; we can say that he was rich, but not with any precision.

The best measure for context is the record that Pórðr tithed 1200 hundrá 1402 , the year of his death, as two other accounts of the tithes of elite priests can be found for comparison. In June of 1401, the priest Einarr Porvarðsson legally adopted his three illegitimate children, in order to assure their inheritance. The adoption record specifies that in the year in which the adoption took place Einarr tithed 245 hundráð, slightly over $20 \%$ of what Pórðr tithed a year later. ${ }^{39}$ Einarr also gave seventy hundráð to each of his two sisters, in order to assure their support for the adoption; with this amount, the sisters could have purchased a small manor each, or three average-sized farms; a comfortable sum, but not in the same scale. Einarr Porvarðsson is otherwise unknown in the documentary record, and may represent a moderately well-off incumbent of a staðr, but not a major church, while Pórðr Pórðarson was one of the wealthiest and most powerful clerics in Iceland at the end of the fourteenth century.

The contrast between Pórðr's hefty tithe and the tithe associated with a wealthy cleric in the early decades of the fourteenth century, however, is much starker. In Lárentíus saga, Bishop Lárentius complained that the priest Snjólfr Sumarliðason was holding back on his tithes, saying that "no other priest held himself so seemingly in food and clothes than Síra Snjólfr, and yet he never tithed any more than forty hundráð. ${ }^{40}$ Snjólfr Sumarliðason was one of the most important priests in the diocese and had held Grenjaðastaðir, the most lucrative benefice in the diocese (although it had been taken away from him some years before). Even though Snjólfr was paying less than his due tithe, the substantial difference between these two sums suggests a massive increase in the personal wealth of elite priests from the 1320 s to the beginning of the fifteenth century.

Pórðr Pórðarson, although extremely wealthy and powerful, nonetheless represented a very typical rise to power. He started out holding a benefice which was important, but not the best in the diocese, and rose to power as the protégé of the very influential Einarr Hafliðason. He held first the position of ráðsmaðr, then became officialis of Hólar, and was a keen administrator, overseeing an inventory of

\footnotetext{
${ }^{39}$ DI III, p. 667.

40 'enginn prestr helt sik svá sæmilega at mat ok klæðum sem Síra Snjólfr, ok tíundaði hann pó aldri meir en fjörutigi hundruð’, Lárentíus saga, p. 388.
} 
the cathedral of Hólar, as well as regular inventories of the parish churches in the diocese. ${ }^{41}$ By contrast, his contemporary Halldórr Loftsson was an unusual cleric. The earliest clear records of him are from 1381, and he died in 1403, probably of the Black Death, which came to Iceland in 1402-03. At his death, he had three living children and a baby on the way; beyond that, it is difficult to say how old he might have been at his death. ${ }^{42}$

The records that exist for Halldórr are very different from the records of other elite priests. Unlike most priests, who often acted as witnesses both to transactions between the laity and the acts of the bishopric, Halldórr witnessed very few documents. ${ }^{43}$ The majority of the documents relating to Halldórr are records of his own actions, and they are actions involving monetary transactions: deeds of sale, records of charitable donations, and his will. ${ }^{44}$ Halldórr's record looks much more like that of a secular aristocrat than a priest, but in every document in which he appeared he was named explicitly as 'Síra Halldórr Loftsson', clearly marking him as an elite priest. Halldórr does not appear ever to have held a benefice; if he did, there is no record of it. In the 1390s, he held at least two provostships, and Flateyjarannáll records for 1381 that he was ráðsmaðr at Hólar, but these are the only official appointments of his that are recorded. ${ }^{45}$

On 23 October 1395, Halldórr Loftsson purchased half of Grund in Eyjafjörður from Björn Einarsson for eighty hundráð, and nineteen hundráð which were owed to the church there. ${ }^{46}$ In 1398 Halldorr bought the other half of Grund together with a property called Holt in Eyjafjörður for land and moveable goods totalling 120 hundráð. ${ }^{47}$ Grund appears to have become Halldórr's main residence. There was a baendarkirkja at Grund which became Halldór's responsibility to maintain (see Chapter 3.1.3). As part of the deed of sale, Björn Einarsson mentions that there was the requirement at Grund to maintain a priest, a deacon, and one

\footnotetext{
${ }^{41}$ DI III, pp. 517, 611; see also Appendix 2.

${ }^{42}$ DI III, p. 685.

${ }^{43}$ The two he did witness are found in DI III, pp. 463, 642.

${ }^{44}$ DI III, p. 359 (sale of part of Bólstaðarhlið to Halldór Loftsson); p. 363 (given half of Kristnes in Eyjafjörður); p. 421 (Marteinn Bessason sold all of Bólstaðarhlið, including the part he got from Halldór); pp. 485-86 (bought the other half of Kristnes); et passim.

${ }^{45}$ Flateyjarannáll, pp. 413, 417, 419.

${ }^{46}$ DI III, pp. 604-05.

${ }^{47}$ Ibid., p. 623.
} 
almsperson. ${ }^{48}$ The language of the sale indicates that responsibility for the maintenance of the church lay with the farm's owner. Moreover, the máldagi for the church at Grund from 1394 records that Halldórr Loftsson gave an expensive breviary (aspiciens bók) 'as the portio ecclesiae over two years'. ${ }^{49}$ Thus, Halldórr appears to be recognised in the máldagi as the person responsible for the portio, or the sum of money set aside for the maintenance of the church. In all, the language of the two deeds of sale is identical to similar deeds of sale between laypeople; there is no indication that Halldórr would treat the property, and specifically the church, any differently than a lay caretaker. ${ }^{50}$

Pórðr Pórðarson and Halldórr Loftsson represent two very different paths to success in a clerical career; at the same time, they shared many of the characteristics of the sub-episcopal elite. They were both wealthy men, and held vast landholdings, which were the main source of their wealth. Moreover, they both held office as diocesan officers: Pórðr as ráðsmaðr and later officialis of Hólar, Halldórr as provost of two provostships, and briefly as ráðsmaðr of Hólar. These two characteristics, wealth and land ownership on the one hand and the holding of diocesan office are typical of the sub-episcopal elite clerics at the end of the fourteenth century.

\subsection{Elite identity in Late Medieval Iceland: Wealth}

Although there has been considerable research into the power of the chieftains in the Commonwealth period, there has been relatively little discussion of the changes undergone by the Icelandic aristocracy after $1264 .{ }^{51}$ Jón Viðar Sigurðsson, who has written on elite identity in Iceland after 1262-64, argued that elites changed from the consensus-based power of chieftains, whose power was based in the support of their

\footnotetext{
48 'her til sagdi hann ath vera æthi aa grunnd prestz skylld oc diakns oc kuengylldz omagha ens skylidazsta af ætt fru vilborgar' [hereto he said that there was to be at Grund the requirement of a priest and a deacon and the indigent person who was most clostly related to Lady Vilborg'], DI III, p. 605.

${ }^{49}$ DI III, p. 524.

${ }^{50}$ See for instance the sale of Ásgeirsá between Magnús Gizzurarson and Jón Hákonarson, DI III, 382-84.

${ }^{51}$ Jón Viðar Sigurðsson, 'The Icelandic Aristocracy'. See also Jón Jóhannesson's study of Gizzur galli, one of the new aristocrats, in Íslendinga saga, II, pp. 302-08.
} 
followers, to what he calls a 'service aristocracy', whose power came from service to the king of Norway. ${ }^{52}$

The notion that there was a fundamental change in the makeup of Iceland's elites after the end of the Commonwealth period is a common one in modern scholarship. Jón Jóhannesson argued that conflicts between the Church and the lay aristocracy weakened the power of the chieftains; as a consequence of the staðamál conflict and the victory of the Treaty of Ögvaldnes, they were forced to abandon their seats of power, the staðir, and were replaced by new families. ${ }^{53}$

To date, no research on the aristocracy in late medieval Iceland has focused on the clerical elite. There are a number of parallels, however, between the new developments in the secular aristocracy, as identified by Jón Viðar and others, and the status of the clerical elites of this period. The most noticeable characteristic of the late medieval aristocracy is the substantial increase in the wealth of aristocrats from the thirteenth to the fifteenth centuries. Jón Viðar, for example, pointed to the difference between the worth of Snorri Sturluson, probably the richest chieftain in thirteenth-century Iceland, and Loftr Guttormsson, an aristocrat from the early fifteenth century. Snorri's property amounted to roughly 2600 hundráð, while Loftr's total property amounted to at least 4300 hundráð, or almost double that of Snorri. ${ }^{54}$ A similar trend can be seen among the clerical elite, who underwent substantial increases in property and total wealth over the course of the fourteenth century.

Secondly, Jón Viðar Sigurðsson pointed to the administrative nature of the Icelandic secular elite after 1319. He described a transformation from kin-based aristocracy to what he called a 'service aristocracy', and claimed that in the period before 1319, 'local chieftains were converted into officers of local government' 55 Here too, clear parallels can be drawn to the sub-episcopal elite clergy. Over the course of the fourteenth century, administrative offices within the Church solidified and gained in importance; the individuals who held these positions became the most powerful officers of the Church, after the bishops.

\footnotetext{
52 Jón Viðar Sigurðsson, ‘The Icelandic Aristocracy', pp. 156-62.

${ }^{53}$ Jón Jóhannesson, Íslendinga saga, II, pp. 108-09.

${ }^{54}$ Jón Viðar Sigurðsson, ‘The Icelandic Aristocracy', p. 164.

${ }^{55}$ Ibid., p. 166.
} 


\subsubsection{Wealth: Staðir and Income}

As I have shown above, there is clear evidence to suggest that some elite priests were very wealthy, and owned land independently of the Church. Given the infrequency with which property transactions were documented at this early period, it seems not unlikely that the practice of buying private property was even more common among elite priests than has been documented. At the same time, the staðir remained a significant source of income for elite priests. The precise nature of this income can be documented, by means of the máldagar, which were regularly kept and updated throughout the course of the fourteenth century.

The first, and most basic source of income was the value of the staðir themselves, and the accompanying livestock. The value of the staðir is hard to assess; when Árni Magnússon and Páll Vídalín made their Jarðabók in 1705, the first comprehensive survey of property values in Iceland, they did not value king's land or benefices. The staðir however, particularly those considered major churches, must be considered to be some of the most lucrative property in Iceland. The larger staðir would likely have been on par with larger manors (höfuðból), valued from 60120 hundráð.

The livestock kept at the staðir are typically listed in the máldagar. In the Vilchinarbók, a collection of máldagar attributed to Bishop Vilchin (1391-1405), the livestock and goods at Oddi were evaluated at the following: one hundred and fifty sheep, twenty-five cows, seven hundráð worth of horses, nine hundráð worth of metfé (goods of variable values), and nine marks of wax. ${ }^{56}$ The holdings of Grenjaðastaðir at a similar time (the collection of Bishop Pétr of 1394) consisted of thirty-five cows, forty kúgildi in sheep, sixty-eight kúgildi in gelded sheep, and ninty-three kúgildi in wares (hafnarvað). ${ }^{57}$ Smaller staðir owned significantly less livestock and goods; Staður í Hrútafirði, for example, owned only eight cows, thirtythree sheep, two rams, an ox, three horses and eleven hundráð in goods. ${ }^{58}$

The importance of land and livestock to the maintenance of the incumbent can be seen in the example from Lárentíus saga of Lárentius' first benefice. As quoted above, Lárentius stayed at the benefice of Háls í Fnjóskadal only a year

\footnotetext{
${ }^{56}$ DI IV, p. 70.

${ }^{57}$ DI III, p. 582.

${ }^{58}$ DI III, p. 165.
} 
because he 'was unlucky with his livestock in his housekeeping ( $p v i$ at honum vildi litt til fjár í búnaðinum). ${ }^{59}$ What precisely the problem was is difficult to say: the máldagar for Háls show a relatively prosperous small farm, with fifteen cows, fifteen sheep, fifteen yearlings, three year-old cows, and twenty-one hundráð in wares (virðingarfé). ${ }^{60}$ Lárentius may simply have been unlucky (or bad at farming), or he may have been put off by the distance from Hólar, and the unusually large number of annexe churches (two half churches and eight chapels). ${ }^{61}$

After the value of the land itself and its livestock, the most valuable source of income from the staðir in many cases must have been their landholdings. Most of the larger staðir (the major churches) owned one or more properties, in addition to the home-farm, the ownership of which determined their status as staðir. Oddi owned the home-farm and eight other properties; two of these were later additions. The first, Neðri-Strönd (the lower beach) was donated by the priest Óli Svarthöfðason and his mother Halla Jónsdóttir. ${ }^{62}$ Óli held Oddi from before 1363 to his death in 1402, and was also officialis in 1399, although he may only have been officialis over the West Fjords, and not over the entire diocese. ${ }^{63}$ The second added property, half the land at Garðvik, was donated by Kolbeinn Pétersson, and the yearly rent given in the máldagi was ten ounces. ${ }^{64}$

What follows is a case study of the land-holdings at Breiðabólstaður í Vesturhópi, in the north-west of Iceland. Breiðabólstaður, as I have shown above, was an extremely important benefice in the development of elite clerical identity, and its significance made it one of the most coveted benefices in the gift of the bishop of Hólar (or indeed, in all of Iceland). In its pattern of land ownership, however, Breiðabólstaður appears to have been typical of the major churches, both in the north and the south of Iceland; it is neither the wealthiest nor the least wealthy of the major churches, and both the number and value of its land holdings are average among the major churches. ${ }^{65}$ Thus this detailed study of a single staðr and its

\footnotetext{
${ }^{59}$ Lárentíus saga, p. 232.

${ }^{60}$ DI III, p, 573.

${ }^{61}$ DI III, p. 573.

${ }^{62}$ DI IV, p. 76.

${ }^{63}$ DI III, pp. 648-49.

${ }^{64}$ DI IV, p. 76.

${ }^{65}$ It held, for instance, only one property less than Oddi, described above. The staðir with atypical landholdings are the staðir in Aðaldalur, a district in the north-east of Hólar (Grenjaðastaðir and Múli). The máldagar for these two properties list the dependent
} 
holdings is illustrative of the land-holdings of most of the major churches (the primary exception being Grenjaðastaðir and Múli in Aðaldalur, see note below).

The staðr at Breiðabólstaður í Vesturhópi owned seven outlying properties, farms called Foss, Grund, Síða, Hundarbak, Allmenningur, Porgrímsstaður, and Sigríðarstaður. ${ }^{66}$ All seven farms are within an easy distance of Breiðabólstaður: Allmenningur and Porgrímsstaður are the furthest from Breiðabólstaður, lying out in the Vatnsnes peninsula, closer to Tjörn í Vatnsnesi (see map 3). Foss and Grund are within two kilometres of Breiðabólstaður. Síða is five kilometres south-east, Urðarbak (Hurðarbak) lies six kilometers to the south, and Sigríðarstaður is roughly ten kilometres from Breiðabólstaður, near Pingeyri. Sigríðastaður was the latest addition, a donation from Einarr Hafliðason. ${ }^{67}$ Foss, the closest in distance to Breiðabólstaður (0.8 kilometres) was also the most integrated dependant property. In the Jarðabók from 1705, it says of Foss that it was 'a rented property (hjáleiga) of the heimastaðr Breiðabólstaður, so old that people do not remember precisely when it was first settled [...] the value of the land is unknown, because this property has never been tithed and is considered to be [part of] the home-farm of the church' ${ }^{6}$ The same was not said of any other property belonging to Breiðabólstaður. While Foss may not have been quite so integrated into the home-farm in the fourteenth century, it is possible that because of its close proximity to Breiðabólstaður it was even at this early date considered different from the other properties. With the exception of Foss, and to a lesser extent the other close-lying properties of Grund and Síða, the location of the properties suggests that while it was deSírable to own land within the district of Vesturhóp, their immediate proximity to Breiðabólstaður was not necessary. This in turn suggests that the selection of these particular properties depended on chance; that properties were donated or bought as they opened up, rather than by design. It could also be that the closer-lying properties of Foss, Grund and Síða (and possibly also Urðarbak) had belonged to Breiðabólstaður

property and drift rights together, naming 34-40 and 19-20 properties or areas of drift rights. in contrast to Oddi's eight, Breiðabólstaður í Fljótsdal's five, and so on. It is not clear why these máldagar are so different, DI II, pp. 431-35; DI IV, p. 81. See also Benedikt Eypórsson, 'History of the Icelandic Church', p. 52.

${ }^{66}$ DI III, p. 167.

${ }^{67}$ Ibid., p. 167.

68 'hjáleiga af heimastaðnum Breiðabólstað, so gömul, að ekki minnast menn nær hún hafi fyrst bygð verið [...] jarðardyrleiki er óviss, pví petta tíundast öngvum og er talið heimaland staðarins', Jarðabók Árna Magnússonar og Páls Vídalíns, 10 vols, ed. by Bogi Melsteð (Copenhagen: Hið íslenska fræðafjelag í Kaupmannahöfn, 1913-1990), VIII (1926), p. 197. 
from an earlier date than the outlying properties of Allmenningur and Porgrímsstaður. This conclusion is also supported by the information that Sigríðarstaður, one of the outlying properties, had been recently added (in the time of Einarr Hafliðason, or 1344-93) and by the order in which the properties are listed in the máldagi.

According to the Jarðabók, Sigríðarstaður was worth sixteen hundráð in 1705, and the land-dues (landskuld) were ninety ells. The worth of Foss was unknown, as mentioned above, but the land-dues were one hundred ells. Grund was valued at twenty-four hundráð and the land-dues were one hundráð and forty ells. Hurðarbak was worth sixteen hundráð and the land-dues were one hundred (tíutíu) ells. Síða was worth twenty-four hundráð and the land-dues were one hundráð and forty ells. Almenningur was valued at twelve hundráð and the land-dues were sixty ells in 1705, but before they had been ninety ells and sometimes forty-five. Porgrímsstaður was worth ten hundráð and was empty in 1705; it owed eighty ells when settled, but this might have gone down to fourty in bad weather years. ${ }^{69}$

These figures are of course for a much later period, but they are consistent with expected property values from the later Middle Ages. As discussed above, the yearly rents for half the land at Garðvík, held by the staðr at Oddi, were ten ounces, roughly sixty ells. Moreover, the average value of a farm in Iceland in this period was twenty hundráð; well in line with the values listed above in the Jarðarbók. ${ }^{70}$ Land could not be alienated from the staðir without being replaced with property of equal value, but the rents were at the disposal of the incumbent. The land-rents in 1705 for the seven properties of Breiðabólstaður add up to six and a half hundráð at the highest rent for the places with varying rents; the livestock-rents (kúgildaleigi) would likely have produced an equal amount. ${ }^{71}$ Thus, the income from seven outlying properties might have totalled in the vicinity of 10-13 hundráð per annum.

What we can see from this case study is that the land-holdings of the staðr were small farms of average value (valued between ten and twenty-four hundráð in 1705), located in the same district as the staðr, but not all directly adjacent to it. It is likely that the oldest properties owned by the staðr were the ones closest to it, while

${ }^{69}$ Jarðabók, pp. 178, 197, 198, 207, 128-30, 148-49.

${ }^{70}$ Björn Porsteinsson and Guðrún Ása Grímsdóttir, 'Norska öldin', p. 90.

${ }^{71}$ Beginning in the fourteenth century, landlords rented livestock at a fixed rate together with the land; see Björn Porsteinsson and Guðrún Ása Grímsdóttir, 'Norska öldin', pp. 98 99; and Jón Jóhannesson, Íslendinga saga, II, p. 199. 
the later acquisitions, including Sigríðarstaður, acquired the latest of the seven in $c$. 1334-92, were located further away, suggesting a pattern of expansion. The income from the rents appears relatively modest (10-13 hundráð per annum) but as we shall see below (section 4.2.2) greatly outstripped the incumbent's income from clerical duties. Although more thorough analysis of the land-holdings of other staðr would be necessary to confirm how common such patterns of property acquisition were, a preliminary survey suggests that Breiðabólstaður í Vesturhópi was typical of the major churches in land-holdings and wealth, making it likely to be representative of the major churches more generally.

In addition to property, the máldagar often list the rights of the church to extract resources from particular places, including the right to fish in particular spots, to cut wood on specified properties, and to collect drift, i.e. driftwood, beached whales and any other resources that might be washed ashore. The máldagar recorded these rights in great detail, listing half-, quarter- and even smaller shares in a given beach, part of a river, or forest. ${ }^{72}$ The máldagi for Staður í Hrútafirði, for example, includes the information that it owned a quarter-share of the drift rights to four locations, a half-share to the drift at Baki and a twelfth-share in beached whales for the whole peninsula ('fyrer fiardar horni'). ${ }^{73}$

Rights to usufruct seem to have been one of the most frequent sources of legal battles, together with arguments over land boundaries. There are several instances preserved in the Diplomatarium Islandicum of judgments on this matter. These include two examples in which Einarr Hafliðason, the priest at Breiðabólstaður from 1344-93, became involved in the case as a judge, representing the bishopric of Hólar. The first case is a conflict over the right of the church at Staðarbakki í Miðfirði to fish in a place called Bláhyl. The document records that on 14 January 1353, Einarr took oaths from two men to the effect that there were fewer fish in the river than usual that summer, and from two other people who said that Síra Porvarðr, the benefice holder, had gone with some people to fish in Bláhyl and had complained that some person had removed the fish from the river. ${ }^{74}$ A similar

\footnotetext{
${ }^{72}$ For example, it says of the church at Melafell that 'hun a allt heimaland. starastadi. halfa brunastadi. siettung $\mathrm{j}$ vikar londum. fiordung i reykum a kieffla backa'. [it owns the whole home-farm, Starastaður, half of Brunastaður, a seventh of the Vík lands, a quarter of the drift at Keflabak], DI III, p. 176.

${ }^{73}$ DI III, p. 163.

${ }^{74}$ DI III, p. 71.
} 
conflict took place in November of 1363, when the abbot of Pingeyri claimed the right to the third part of a beached whale which had been taken away by a layman, Snorri Steinsson, from a river-mouth to which Pingeyri owned drift rights. When the bishop learned of this conflict, he commanded that no lay person had the right to judge in this case, and asked Einarr Hafliðason to personally determine if a tithe was due or not to Pingeyri, and to make the settlement. ${ }^{75}$ These and countless other examples of conflicts over usufruct highlight the value of such rights to the holder of a particular staðr (see also Appendix 3.2 for an example of such a case). Moreover, these cases, most often judged by the officialis or another representative of the bishop, appear to have been most commonly resolved in favour of the clerical litigant, in the event of a conflict between a cleric and a layperson. By upholding the rights of the benefice-holders, these judges allowed the holdings of the staðir to continue to grow, protected from the incursions of laypeople and others.

As I have demonstrated above, property was an important source of wealth for the sub-episcopal elite. As discussed above, more detailed studies of land ownership and property transaction are needed; I have provided a case study of the landholdings of the staðr at Breiðabólstaður í Vesturhópi to demonstrate what can be known about landholdings, and the distribution of a typical staðr's wealth. The wealth of the staðir was held in livestock, land, and usufruct; as I have shown above, these resources were protected with the authority of the Church, allowing the beneficed clergy to increase their wealth and landholdings.

\subsubsection{Clerical Income}

In addition to the income from the staðir purely as manors, farms with dependant properties attached, the staðir were also parish churches, and their incumbents earned an income from the tithes, tolls, and incidental fees which accompanied their parochial duties.

The first Church fee owed to the incumbent was the quarter of the tithe which was owed to the priest, and the quarter of the tithe which was owed for the maintenance of the church building. As discussed in the previous chapter (Chapter 3.1.2), Gunnar F. Guðmundsson calculated that the average income for a parish

\footnotetext{
${ }^{75}$ DI III, pp. 200-02.
} 
church in tithes was seventy ells of vaðmál, and the highest income no more than 120 ells. ${ }^{76}$ Máldagar from the collections of Bishop Pétr record in many cases the amount of the tithe owed for the maintenance of the church (tiund kirkju hluti) for the year in which the máldagi was written. The church's quarter of the tithe for Grenjaðastaðir in the year of Bishop Pétr's máldagabók was twelve ounces, payable from nineteen farms. ${ }^{77}$ The tithe paid to the incumbent of Grenjaðastaðir was therefore twice that amount, or twenty-four ounces, as he held both the quarter for the priest, and the quarter for the church building. ${ }^{78}$ Other churches in the diocese of Hólar record comparable tithes. The church's quarter of the tithe for Háls í Fnjóskadal, for example, was thirteen and a half ounces, that of the church at Hrafnagil in Eyjafjörður was valued at one hundráð and one mark, paid from seventeen farms. ${ }^{79}$ That for Múli was one mark, paid from eleven farms. ${ }^{80}$ Unfortunately, the máldagar for the diocese of Skálholt do not list the churches' tithes. They are likely to have been somewhat higher than the tithes from the diocese of Hólar, as the largest churches in Skálholt had much larger tithing areas on average. $^{81}$

In addition to the tithe, many máldagar specified specific tolls owed to the parish church. The most common of these were the hay-toll (heytollur) and light-toll (ljóstoll). The hay-toll consisted of one horse-load of hay, to be paid to the staðr no later delivered no later than 8 September. ${ }^{82}$ The light-toll was a tax for candles, payable as either two ells of vaðmál or two marks of wax. ${ }^{83}$ Additionally, the parish church charged the mortualia, which was twelve ells of vaðmál, the funeral mass fee of six ells, and the chrism-fee for the last rites, eighteen ells. ${ }^{84}$ As the tithe and other service-based fees were variable, the yearly income of a priest based on ecclesiastical fees cannot easily be calculated. However, for the incumbent of a

\footnotetext{
${ }^{76}$ Gunnar F. Guðmundsson,'Guði til pægðar eða höfðingjum í hag?: Níu aldir frá lögtöku tíundar á Íslandi', Ný Saga, 9 (1997), 57-64.

${ }_{77}$ DI III, p. 582. The collection is dated to 1394 , but as with all the máldagar, the dating is not necessarily so exact.

${ }^{78}$ Björn Porsteinsson, Guðrún Ása Grímsdóttir, 'Norska öldin', p. 103

${ }^{79}$ DI III, p. 573.

${ }^{80}$ DI III, p. 578.

${ }^{81}$ On tithing areas (ministry sizes) see especially Orri Vésteinsson, The Christianization of Iceland, pp. 238-46 (especially p. 241).

${ }^{82}$ Gunnar F. Guðmundsson, 'Íslenskt samfélag', p. 185.

${ }^{83}$ Ibid., pp. 183-84.

${ }^{84}$ Ibid., p. 185.
} 
major church with significant land holdings, the income from land and cattle rents was probably significantly greater than that from tithes and ecclesiastical fees.

The division between the income of the incumbent and that belonging to the church was made explicit in some of the máldagar. The máldagi for Háls í Fnjóskadal contains a clause which specifies the relation of the property of the church there to the incumbent. The clause goes as follows:

He who lives on the staðr shall protect it and all its goods. [He shall] maintain the house and the yard, and have for this ten hundred-weights in wood and thus the timber which he needs for buildings or to make farm implements. He shall not sell [a portion] from the woods, unless it should be used for the improvement of the staðr, or unless some other wealth should be given to the staðr [in its place]. He shall have all the tithes, and the entire mortualia. But everything which is given additionally with the body, and anything else which is given, the staðr owns that, with this condition that he who gives them shall also say and make clear before the priest and neighbours who are present clearly that he wants to let that money go [in such a way]. In that case it is right for the money to go to books and vestments and other church improvements.

Sa er a stad byr skal abyrgiast hann og allt hans gods. hallda hvsum oc gordum. hafa til. $x$. vætta $\mathrm{j}$ skogi. og suo timbur sem parf thil hvsa edur ad Bvhlutum ad giora. Eigi skal hann selia vr skogum nema til stadarbota sie lagt. edur annat fie sie ella lagt $\mathrm{j}$ stadinn. hann skal hafa tijundir allar og legkaup aull. Enn allt pad sem meira er giefid med lijkum en suo. enn annars kostar gefid. pá á stadur pad pess kostar. ad sá skal \& kueda og lysa fyrer presti og nabvum er til giefur til huðrs ad vill pad fie fara láta. Riett er pui fie ad veria til Boka oc messuklæda og annarar kyrckiuprydi. ${ }^{85}$

As this passage makes clear, the relationship between the incumbent and the church was well-defined, and at least at Múli, the income was strictly divided into that which went to the incumbent, and that which went to the church. In this sense, the incumbent of a staðr was actually in a very similar position to the lay owner of a bandarkirkja, who was obligated by the contractual nature of the máldagar to uphold the property rights of the incorporated church, and fulfil any obligations set out in the máldagi. $^{86}$

\footnotetext{
${ }^{85}$ DI III, p. 578.

${ }^{86}$ On the máldagar as contracts, see for instance Orri Vésteinsson, The Christianization of Iceland, p. 293; see also DI III, pp. 382-84, a deed of sale which discusses the obligations of a secular owner towards a half-church on his property.
} 


\subsection{Conclusion: Staðir and Wealth}

The sources of income of an elite Icelandic beneficed cleric were varied and numerous: tithes, fees, and other forms of clerical income, as well as the wealth of the staðr in livestock, land, and usufruct. Additionally, by the end of the fourteenth century, many individual clerics held their own property, independent of the staðir. Wealth and landholdings were one of the defining features of the Icelandic aristocracy after 1300, and these characteristics also defined the Icelandic Church in the period leading up to the Reformation. What I have provided here is a study of the wealth and landholdings of the beneficed clergy who straddled both of these identities: aristocratic and ecclesiastical. Through a series of case studies, I have revealed a great deal about the wealth of the beneficed elite clergy. In the first place, we can see that the beneficed clergy drew their income from a wide range of sources; clerical fees, the income of the staðir and their own personal landholdings. Moreover, the wealth drawn from the staðir and from personal landholdings increased over the course of the fourteenth century, as the beneficial system stabilised. Secondly, analysis of the economic basis of clerical income provides an important counterweight to the evidence of clerical narratives. In Lárentíus saga, the annals, and other clerical narratives, the wealth of the staðir is not described in depth, and the day-to-day duties and sources of income of the beneficed elite are described vaguely, if at all. Moreover, as I discuss below, the annals and Lárentíus saga present a picture of the sub-episcopal elite as highly mobile, moving around the diocese and the country, as well as travelling frequently to Norway and elsewhere abroad. The economic evidence of máldagar and court cases involving drift rights, on the other hand, remind us on the other hand of the local interests of the beneficed elite. The incumbents of the staðir, in addition to their connections at the diocesan level and with their metropolitan, also maintained local ties, involving themselves in legal disputes over drift rights, property boundaries, and the rights of the staðir. The importance of local connections and of the immediate concerns of maintaining and running a large staðr are important concerns to keep in mind also in the following discussions, in which I describe connections between the sub-episcopal elite and the bishop, and the role of the sub-episcopal elite in running and maintaining the diocese. 


\subsection{Elite Clerical Social Networks}

Social networks were an integral part of elite clerical identity. ${ }^{87}$ This included both vertical ties (ties between a social superior and inferior, such as patron-client relations) between the bishop and his followers as well as the more lateral ties (ties between relative equals) between individual members of the sub-episcopal elite. The study of social networks in medieval Iceland has primarily been confined to studies of familial ties (most notably in the context of feud and personal honour in the Íslendingasögur), and the vertical ties between the goðar or chieftains and their followers among the farmers (bandur) ${ }^{88}$ For clerics in the fourteenth century, however, these ties were subsumed to the relationships between members of the subepiscopal elite, some of which mirrored these secular bonds of family and chieftainfollower. Important relationships included the ties between a teacher and his pupils, a bishop and his clerks, between clerics who had studied together, whether in childhood or in young adulthood, and between clerics who worked together or inhabited the same network of mesthattar prestar, the most powerful priests of the diocese.

In addition to relationships amongst members of the clergy, the sub-episcopal elite also formed important ties to the new secular aristocracy, including the secular officials, the hirðstjórar and the lögmenn, as well as other members of the aristocracy (on the secular aristocracy, see Chapter 1.3). The relationships which were formed between members of the lay aristocracy and the clerical elite of Iceland have not yet been fully explored. Here too, the study of community and social networks might prove useful, as will this study of ties within the secular clergy, especially relationships between colleagues, and relationships between the mestháttar prestar and the bishops whom they served. In what follows, I focus on relationships of loyalty and friendship between bishops and their clerical supporters, including the practice of elite clerics acting as advisors to the bishops, as well as

\footnotetext{
${ }^{87}$ Social network theory has long been in use among sociologists and anthropologists; for notable examples of its application in historical research, see for instance Robert Jütte, Poverty and Deviance; see also Christianity and Community in the West; for a study of social networks in the Icelandic context, see especially Gísli Ágúst Gunnlaugsson and Loftur Guttormsson, 'Cementing Alliances?'.

${ }^{88}$ William Ian Miller, Bloodtaking and Peacemaking; see also Jesse Byock, Society, Sagas, and Power; and Jón Viðar Sigurðsson, 'Friendship in the Icelandic Commonwealth'.
} 
clerical reactions to the arrival of a new bishop. I discuss briefly clerical concubinage and the role of clerics' children in forming social networks within the clergy, and end with a discussion of armed and unarmed conflict between the bishop of Hólar and the monasteries in the north of Iceland, with a focus on the networks of alliances and friendship which could be mobilised in the event of violent conflicts.

\subsubsection{Relations with the Bishop: Ties of Loyalty and Friendship}

Orri Vésteinsson wrote of the earliest bishops that, 'the basis of the bishops' power was of course in reality different from that of the chieftains, but it was natural for them to assume as their role-model the ideal chieftain'. ${ }^{89}$ Orri argued that over the course of the twelfth and thirteenth centuries this changed dramatically, and the bishops developed a power based more firmly on institutional strength and the power of the Church. ${ }^{90}$ As discussed above, Jón Viðar Sigurðsson has argued that from 1271 to 1319 , the kin-based aristocracy was replaced by a service aristocracy, which obtained its power not through the consent and support of the householding class which it led, but rather through appointment by and service to the king. Thus, together with the old kin-based aristocracy, 'the vertical ties of loyalty between chieftains and householders disappeared'. ${ }^{91}$ In both accounts, what is emphasised is change, particularly after 1300 .

The clerical elite showed many characteristics of Jón Viðar Sigurðsson's 'service aristocracy', as I have shown above. At the same time, however, I would argue that in spite of drastic changes to the institution of the Church and to sources of ecclesiastical power, the basic relationship between a bishop and the elite clergy continued to be modelled on that of a chieftain and his followers. Lárentíus saga provides numerous examples of the ideal relationship between a bishop and the most powerful priests in his diocese. This relationship resembles the client-patron relationship described by Jón Viðar Sigurðsson as the basis of the kin-based chieftaincies of the Commonwealth period. ${ }^{92}$ This relationship depended on mutual

\footnotetext{
${ }^{89}$ Orri Vésteinsson, The Christianization of Iceland, p. 164.

${ }^{90}$ Orri Vésteinsson, The Christianization of Iceland. See for instance Orri Vésteinsson's discussion of the episcopate of Bishop Brandr and the role of clerics as mediators, pp. 22334.

${ }^{91}$ Jón Viðar Sigurðsson, ‘The Icelandic Aristocracy’, p. 161.

${ }^{92}$ Ibid., pp. 154-55.
} 
friendship and loyalty, a reciprocal bond which strengthened both parties. This reciprocity can be seen in the reconciliation of Bishop Auðunn rauði, then bishop of Hólar, and Lárentius, at this time a monk in the monastery of Pingeyri:

In the fall, Síra Egill mediated that Lord Bishop Auðunn and Brother Lárentius should come to terms; Síra Egill put it to the bishop that it would be a great strength for him to have such a man as Lárentius was [...] and the Lord Bishop received him [Lárentius] honourably, confirming his friendship to him while Brother Lárentius for his part [confirmed] his obedience.

Um haustit gekk Síra Egill í meðal at peir herra Auðun byskup ok bróðir Laurentius skyldu sættaz; leiddi Síra Egill fyrir augum byskupinum at honum var mikill styrkr at slíkum manni sem Laurentius var.[...] ok tók herra byskup heiðarliga við honum, játandi honum sinni vináttu en bróðir Laurentius par í mót sinn hlýðni. ${ }^{93}$

The friendship of the bishop here was formally reciprocated by the obedience of the cleric; this took place in a formal ceremony of reception, in which Auðunn's friendship (vinátta) and Lárentius' obedience (hlýðni) were formally declared. Significantly, Egill, the mediator was able to persuade the bishop to settle with Lárentius by arguing that Lárentius' support would strengthen the bishop's position; here we see the suggestion that a bishop's power, like that of the ideal chieftain, was increased by the support of capable and well-connected followers.

Bishop Auðunn's episcopate also provides some clear examples of the relationship between bishop and elite priest breaking down, and these reveal the necessity of strong ties between the bishop and the sub-episcopal elite. Moreover, these passages also show the power of the sub-episcopal elite to hinder an unfriendly bishop. Bishop Auðunn's arrival at Hólar shows the initial tensions and the consequences of poor relations with the 'most powerful priests':

He [Auðunn] rode north over Sand [Stórasand] to Hólar. All of the most powerful priests were there already; he was greeted disdainfully at Hólar. He was very stiff from riding, because he was an old man. Síra Koðrán and Síra Snjólfr laughed at him. He showed that he thought poorly of this.

Reið hann norðr Sand til Hóla. Vóru par allir mestháttar prestar fyrir; var á staðnum ómetnaðarsamliga við honum tekit. Var hann mjök stirðr af reið, pví at hann var maðr

\footnotetext{
${ }^{93}$ Lárentíus saga, p. 338.
} 
gamall; höfðu peir sira Koðrán ok sira Snjólfr allt í skaupi við hann; lét hann sér fátt um finnaz. ${ }^{94}$

Síra Koðrán Hranason and Síra Snjólfr Sumarliðason were two of the most powerful priests in Hólar at the time of Bishop Auðunn's arrival in 1313. Koðrán held Grenjaðastaðir at the time and Snjólfr had been one of the strongest supporters of Bishop Jörundr Porsteinsson (1267-1313). In this passage we see the structural support for the new bishop: all of the mestháttar prestar gathered at Hólar to greet their new bishop. However, their reaction is disdainful, and sets the tone for the disputes to come. Later that year, the struggles between Bishop Auðunn and the two priests, Koðrán and Snjólfr, renewed:

In the winter, there was a great quarrel and a rift between Síra Koðrán and Síra Snjólfr on the one side, and Lord Bishop Auðunn on the other. They both held against him as one, and they appealed to the archbishop at first. Lord Bishop Auðunn took Grenjaðastaðir from Síra Koðrán. Then Síra Snjólfr went to the side of the bishop and received Grenjaðastaðir.

Mikit missætti ok sundrlyndi gjörðiz um vetrinn meðal sira Koðráns ok sira Snjólfs af annarri hálfu, en herra Auðunar byskups af annarri; heldu peir eitt báđir í mót honum, appelleruðu peir til erkibyskups í fyrstu. Tók herra Auðun byskup Grenjaðarstað af sira Koðráni; gekk Snjólfr til handa byskupi síðan ok pá Grenjaðarstað. ${ }^{95}$

In this passage, as well as in the episode which follows, we see a number of tactics used by the bishop to gain the support of the priests. Here, the bishop attempted to use his power to take away lucrative benefices from troublemakers, and then give them strategically in exchange for support. Bishop Auðunn here took Grenjaðastaðir from Koðrán, one of his two most prominent opponents, and gave it to Snjólfr, his other opponent, in exchange for Snjólfr's support. Grenjaðastaðir, the wealthiest benefice in the northern diocese, changed hands eighteen times over the course of the fourteenth century; the highest turnover known for any benefice in Iceland at this time. ${ }^{96}$ Snjólfr himself did not manage to keep Grenjaðastaðir for long; Bishop

\footnotetext{
${ }^{94}$ Ibid. p. 321.

${ }^{95}$ Lárentius saga, p. 322.

${ }^{96}$ Sveinn Nielsson, Prestatal og Prófasta, pp. 302-03. By comparison, Prestatal lists only four incumbents for Oddi í Rángárvöllum for the period 1300-1402 (p. 64), although this is likely a result of poor records from the diocese of Skálholt from this period. For Breiðabólstaður í Vesturhópi, for which the fourteenth-century record is almost certainly very close to, if not entirely complete, Sveinn Nielsson records 6 incumbants from before 1309 to 1402, Prestatal, p. 223.
} 
Auðunn took it away from him a few years later, when Snjólfr refused to accept a cleric in minor orders whom Bishop Auðunn had assigned to Grenjaðastaðir. ${ }^{97}$ Through the judicious use of his power to give or take away the most lucrative and most prestigious benefice in the diocese, Auðunn was able to manage the opposition of these two mestháttar prestar. At the same time, their continued opposition to him, combined with the general lack of support Auðunn suffered greatly weakened his episcopacy, impeding his ability to carry out his will in the diocese.

In addition to the lure of a lucrative benefice, Bishop Auðunn also attempted to attract the support of the priests of his diocese using the promise of granting dispensations to their sons. Among the other sons of prominent clerics, Bishop Auðunn granted a dispensation to Jón Koðránsson, the son of Koðrán Hranason. ${ }^{98}$ The saga here specifies, however, that Bishop Auðunn was 'poorly repaid' for his efforts here, as only one of the fathers, Hafliði Steinsson, returned this favour with his explicit support. ${ }^{99}$

All the priests were then against him in conspiracies and open hostility, with the exception of Síra Hafliði from Breiðabólstaður. The bishop gave him good gifts, but he and Koðrán parted without coming to a settlement. Lord Bishop Auðunn was poorly repaid for the goodwill which he showed to the most powerful priests because he granted dispensations to their sons, because he had received this power from the pope.

Vóru allir prestar pá í samblástri ok mótgangi í móti honum utan síra Hafliði af Breiðabólstað, gaf byskupinn honum góðar gjafir, en peir Koðrán skildu ósáttir. Var herra Auðuni byskupi lítt umbunaðr sá góðvili sem hann sýndi mestháttar prestum pví at hann dispenseraði með sonum peira, pví at hann hafði vald til pess af páfanum. ${ }^{100}$

In this passage, we see the explicit contrast between Bishop Auðunn's treatment of his supporter, Hafliði Steinsson, to whom he 'gave good gifts', a traditional marker of friendship, and his parting with Koðrán Hranason, 'without coming to a settlement' (quoted in full above). Moreover, we see how the bishop's use of the power of dispensation granted to him by the pope was dictated by his specific political needs within the diocese: the need to court the support of the mestháttar

\footnotetext{
${ }^{97}$ Lárentíus saga, p. 341.

${ }^{98}$ Lárentíus saga, p. 330.

${ }^{99}$ This phrasing does not however occur in the B text, which states only that 'Auðun byskup dispenseraði með pessum prestasonum' [Bishop Auðun granted dispensations to these sons of priests], Lárentíus saga, p. 329.

${ }^{100}$ Lárentíus saga, pp. 329-30.
} 
prestar. ${ }^{101}$ The passage from Lárentíus saga shows how this power could be used to create or strengthen connections between the bishop and the mesthattar prestar. I will discuss in more detail below the social bonds created by clerical fosterage of sons; here it is worth mentioning only that Einarr Hafliðason, the author of Lárentius saga, was himself one of the six boys to be granted dispensation for defect of birth by Bishop Auðunn in 1317 (see Table 4). Throughout his own career, Einarr himself supported some of the bishops he served under ferociously (Lárentius, Egill, and Jón skalli); his Lögmannsannáll shows, however, his deep-rooted dislike of, and opposition to, Bishop Ormr Ásláksson (1342-56). ${ }^{102}$ The power of such opposition on the part of the mestháttar prestar, the most powerful priests of the district can be seen from the above descriptions of Bishop Auðunn's difficulties in the early part of his episcopate. His efforts to secure the support of the priests, and to minimise the damage they could do, show the importance of their support. This extended description of an instance in which the ties of loyalty and friendship were not present between the bishop and the sub-episcopal elite shows perhaps more clearly than the examples of its presence how important such ties truly were.

\subsubsection{Advisors to the Bishop}

The friendship of bishops took material form for the sub-episcopal elite in lucrative benefices, and also in providing support for the education and early careers of their sons. In exchange, priests offered 'obedience' (hlyðni). In some cases, this consisted of running errands for the bishop, particularly carrying messages or pursuing cases in Norway (see Chapter 5.2.2). Another regular duty expected of the mestháttar prestar was that they would act as advisors to the bishop, when called upon to do so. In this, the highest elite priests may have taken the place of cathedral canons, an institution which was never successfully established in Iceland. Of course, although advising the bishop was expected of the most powerful priests, as a service to the bishop, it

\footnotetext{
101 On papal dispensation, see especially Ludwig Schmugge, Kirche, Kinder, Karrieren: Päpstliche Dispense von der unehelichen Geburt im Spätmittelalter (Zürich: Artemis \& Winkler, 1995), especially on the delegation of dispensations to the archbishop of Niðarós, p. 44. Guðmundr J. Guðmundsson has edited and translated the ten extant letters of supplication to the papacy in the fifteenth century, of which two dealt with defect of birth, 'Tíu páfabréf frá 15. öld', Saga, 46 (2008), 56-75 (pp. 67-68, 73).

${ }^{102}$ See Chapters 2.2.2 and 2.3.3. See also Rowe, 'The Flateyjarbók Annals', p. 240.
} 
must also have been an important way for the sub-episcopal elite to exert influence as an advisory body.

For important decisions, the bishop could call the priests to him. During the Möðruvallamál, Bishop Lárentius’ conflict with the friars of Möðruvellir, Lárentius was ordered by Bishop Jón Halldórsson and Abbot Pórlákr, the adjudicators in the case, to come to Möðruvellir in the summer of 1327 and answer accusations that he had broken his part of their previous agreement. Angry and reluctant to obey this summons, Bishop Lárentius called a meeting of his advisors:

Bishop Lárentius called to himself the foremost priests: Síra Porsteinn skarðsteinn, Síra Egill, Síra Jón, Síra Eiríkr bolli. He had intended to conduct a visitation around the northern district, but he stayed at Laufsás when it was near to the appointed day. Then he took council (trakteraði) and discussed (ráðgjörð) with his priests what was most advisable. It was agreed among them (kom pat ásamt með peim) that he should go to Möðruvellir at the appointed day. It seemed not unlikely that the judgements of each of them [Bishop Jón and Abbot Pórlákr] would go forward to the detriment of Hólar church if its representative was not there [...] He [Lárentius] showed them ecclesiastical law [to the effect] that they [the adjudicators] had no power to judge since the agreement was between him and the friars, and said that he had not broken it in any way. In the end he had his priests decide, and Bishop Lárentius and the priests went on a ship over to Möðruvellir.

Kallaði Laurentius byskup at sér fremstu presta: sira Porstein skarðstein, sira Egil, sira Jón, sira Eirík bolla. Hafði hann ætlat at visitera um norðrsveitir, en sat í Laufsási pá er at leið stefnudeginum. Trakteraði hann pá ok hafði ráðgjörð við presta sína hvat ráðligast væri. Kom pat ásamt með peim at hann skyldi koma til Möðruvalla í stefnudaginn; pætti eigi ólíkligt at peir dómar mundu fram fara eins hverir með órskurð at skaða kirkjuna á Hólum ef eigi væri par svaramaðr hennar [...] Hann sýndi peim lög kirkjunnar at peir áttu ekki vald yfir at dæma síðan sáttmál kom á meðal peira bræðra, en sagði sik í engu pat rofit hafa. Par kom at hann lét presta sína ráða, ok fór Laurentius byskup ok prestarnir á skipum yfir til Möðruvalla. ${ }^{103}$

This is one of the more detailed descriptions of a meeting of priests available. Two of the named priests, Síra Porsteinn skarðsteinn and Síra Egill Eyjólfsson, are known. At this time, Porsteinn was the incumbent of Breiðabólstaður í Vesturhópi, and Egill was the incumbent of Grenjaðastaðir, the two most important benefices in the diocese of Hólar. Síra Jón and Síra Eiríkr are unknown individuals. In the saga, this lengthy description of the role of the priests as advisors serves the purpose of emphasising Bishop Lárentius' reluctance to submit to adjudication. It raises,

${ }^{103}$ Lárentíus saga, pp. 401-02. 
however, some interesting questions about the practicalities of clerical advising. Although many of these priests must have had a residence at the bishopric, they likely used the staðir as their main residences. Lárentíus saga presents a picture of an elite beneficed clergy ready to convene at Hólar, or wherever the bishop might be, at a moment's notice; even more importantly, perhaps, the saga paints a picture of an elite beneficed clergy whose main concern was with diocesan politics and connections focused around the bishopric at Hólar. As I have discussed above, this cannot always have been the case, as local concerns and regional connections must also have played a part in the lives of the beneficed clergy.

\subsubsection{The Newly-Arrived Bishop}

With so much depending on a good relationship with the bishop, the arrival of a new bishop must have been the cause of considerable concern for the sub-episcopal elite. The uncertainty must have been greatest when awaiting the arrival of non-Icelandic bishops, with whom the Icelandic clergy were unlikely to have had a previous relationship. For the most part, however, the incoming bishops seem to have preferred continuity in administrative positions and benefices. Only rarely do we see individuals losing their positions upon the arrival of a new bishop. The career of Einarr Hafliðason, who lived to serve five bishops of Hólar over a seventy-year period, is a good example of this. Einarr first held the position of officialis at the death of Bishop Egill Eyjólfsson in 1341. This was clearly a position sede vacante, which he lost at the arrival of Bishop Ormr Ásláksson in 1342. But although he lost the position of officialis at the arrival of the new bishop, Einarr received the benefice of Breiðabólstaður í Vesturhópi from Bishop Ormr in the year of his arrival.

In Skálholt, the career of officialis Snorri kyngir Porsteinsson shows the same continuity, as Snorri served under three different bishops, from 1355 to 1379, as described in Chapter 3. He first appears as officialis in 1355, when Bishop Gyrðr left the country for Norway. He acted as officialis again in 1360, after the death of Bishop Gyrðr, and again in 1369 to his death in 1379, during the episcopate of Bishop Oddgeirr Porsteinsson (1365-81). ${ }^{104}$ In spite of the continuity evidenced by the careers of these two administrators, the sub-episcopal elite could also be deprived

${ }^{104}$ Chapter 3.2.2; see also Appendix 2. 
of their positions through conflict with the bishop, as the annals describe. The uncertainty surrounding the arrival of a new bishop can be seen most clearly in later sources, such as this entry from Flateyjarannáll:

Lord Pétr Nikúlásson arrived [...] the bishop rode home to Hólar immediately in the fall and with him the priest Jón Magnússon; one Danish monk who was called Enis; Lord Sveinn; Priest Matthías who was related to the bishop; Sveinn the deacon; Pétr gammi the cook, a servant-all Danish. Porsteinn the clerk, a Norwegian; Jón sléttr; and Ormr, a Shetlander. Síra Einarr Hafliðason kept the position of officialis and all his power and was in the greatest friendship with the bishop. Síra Pórðr kept the management ( ráð) of Hólar. It was rather cool between the bishop and Síra Steinmóðr Porsteinsson because he kept all his honours and positions. The bishop allowed all the priests to keep their powers. Lord Abbot Porsteinn kept all his powers and the diocese [Skálholt] was thought then to be in rather good standing. Síra - held the position of ráðsmaðr at Skálholt.

kom vt herra Petr Nichulasson [...] reid byskup heim til Hola pegar vm haustid ok med honum Jonn prest Magnusson. brodir einn danskr er Enis het herra Sueinn prestr mathis skylldr byskupi. Sueinn diakn Petr gammi steikari smasueinn allir danskir. Porstein klerkr norönn mann. Jonn slettr $o k$ Ormr hialltlenzskr mann. hellt sira Einar Haflida son officiolatus starfui $o k$ allri sinni makt $o k$ var i mestum kærleikum vid byskup. hellt sira Pordr Hola raadum var helldr faatt med byskupi ok sira Steinmodi Porsteins syni. pess at hann hellt ollum sinum heidri ok storfum leet byskup alla presta hallda sinum vaulldum. hellt herra Porsteinn abboti ollum sinum volldum ok potti pa byskupsdamid helldr vel standanda. hellt sira — raadum i Skaahollti. ${ }^{105}$

Pétr Nikúlásson (1391-1411) was the first bishop of Hólar to have been appointed by the pope, rather than the archbishop of Niðarós, and the first Danish bishop of Hólar (Bishop Michael had been appointed bishop of Skálholt in 1382), and his arrival thus had the potential to be particularly disruptive. The description of his household, and the nationality of each servant, is unusual for the annals. It is possible that this was the first time a bishop had brought a large number of servants and clerks from abroad; however, it could also be that a large household of Danish people was more noteworthy than a large household of Norwegian servants. The annalist seems to have found the arrival of the new bishop and his foreign household rather threatening; this is suggested both by his emphasis on the nationality of each servant, as well as the apposition of a list of the new arrivals followed by the assurance that the most powerful Icelandic priests kept their positions of power.

${ }^{105}$ Flateyjarannáll, pp. 418-19. The mark - indicates a blank space left in the manuscript for the name of the ráðsmaðr of Skálholt, Teitr Oddsson (see below, Appendix 2). 
Through its reassurances that Einarr Hafliðason, Pórðr Pórðarson, Steinmóðr Porsteinsson, and 'all the priests' (see above) kept their former positions, the annal entry suggests that these clerics, and the annalist, were worried about the possibility of losing their powers. The passage ends on a note of stability; both the officialis and the ráðsmaðr of Skálholt remained the same. The annalist clearly thought this was noteworthy, even though he did not immediately remember the name of the ráðsmaðr of Skálholt. The effect is to emphasise continuity in spite of the disturbing new arrivals.

The fear of losing one's position, especially at the arrival of a new bishop, can be seen throughout the later annals. A few years after the arrival of Bishop Michael, Flateyjarannáll reports that 'many priests were without an office (embatti) in the diocese of Skálholt and many novelties created by Bishop Michael'. ${ }^{106}$ This fear seems to have been particularly strong in the last couple of decades of the fourteenth century, with the arrival of the Danish bishops appointed by the pope.

Thus, although the elite beneficed clergy were in a position to make life difficult for their bishop, as shown through the discussion above of the episcopate of Bishop Auðunn, they too could be deprived of valued administrative positions through the displeasure of the bishop. As this and previous discussions have made clear, the relationship between the bishops and the sub-episcopal elite was one of the most important relationships for the elite beneficed clergy, whether it was a good relationship, as in the case of Bishop Lárentius and his priests, or a bad or uncertain one, as with Bishop Auðunn or Bishop Pétr. Whether their relationship with the bishop was one of friendship or antagonism, it was clearly foremost in the minds of clerical writers such as Einarr Hafliðason and the annalists.

\subsubsection{Archiepiscopal Benefices}

Magnús Stefánsson has argued that the largest and most politically important benefices in Iceland were in the gift of the archbishop of Niðarós, and thus archiepiscopal benefices (erkibiskupslén). He points specifically to Oddi, Hítardalur, Grenjaðastaðir í Aðaldal and Breiðabólstaður í Vesturhópi as examples of

106 'embættis lausir margir prestar i Skalholltz byskupsdæmi ok margar nylundr giorfar af Michele byskupi’, Flateyjarannáll, p. 415. 
archiepiscopal benefices. ${ }^{107}$ Magnús cites an example from Íslendingasaga in the Sturlungasaga compilation, where it says that in 1259 the chieftain Ásgrímr Porsteinsson came to Iceland with a letter from Archbishop Einarr assigning him to the staðr at Grenjaðastaðir. Additionally, a 1449 letter from Archbishop Áslákr to Bishop Gottskálk of Hólar (1442-57) suggests that at that time the benefices of Oddi, Hítardalur, Grenjaðastaðir, and Breiðabólstaður í Vesturhópi were in the gift of the archbishop of Niðarós. ${ }^{108}$

While these four staðir may well have been in the gift of the archbishop of Niðarós by the mid-fifteenth century, there is no evidence to suggest that this was in fact the case in the fourteenth century or earlier. In the late fourteenth century, the appointments of Icelandic bishops came under the power of the papacy in Rome, while in the mid-fifteenth century the powers of the archbishop of Niðarós were significantly strengthened as a result of the Council of Basil; in fact, Bishop Gottskálk of Hólar was the first bishop in Iceland to be appointed by the archbishop in over fifty years. ${ }^{109}$ With these changes to the powers of papacy and archbishopric in the fifteenth century, there is no reason to believe that fifteenth-century evidence could be relevant to earlier periods in the realm of archiepiscopal appointments and patronage.

Fourteenth-century evidence suggests, on the contrary, that the archbishop of Niðarós could intervene in the gifting of a benefice only under specific conditions, and this was probably not commonplace. One clear example is that of Egill Eyjólfsson, who was granted the benefice of Grenjaðastaðir in 1324 by Archbishop Eilífr. Lárentíus saga stated explicitly that the archbishop 'thought it [the benefice] to be in and to have fallen to his power on account of the mismanagement of Bishop Auðunn'. ${ }^{110}$ Bishop Auðunn had died without appointing a priest to Grenjaðastaðir, and as Guðrún Ása Grímsdóttir makes clear in her note to the text, bishops had a three-month period in which to fill vacant benefices. ${ }^{111}$ The archbishop's assessment of the situation is somewhat misleading, however. Before leaving to be consecrated

\footnotetext{
${ }^{107}$ Magnús Stefánsson, Staðir og staðamál, p. 212.

${ }^{108}$ DI IV, pp. 752-53.

${ }^{109}$ Björn Porsteinsson and Guðrún Ása Grímsdóttir, 'Enska öldin', in Saga Íslands: Samin að tilhlutan Pjóðhátíðarnefndar 1974, ed. by Sigurður Lindal, 5 vols (Reykjavík: Hið íslenzka bókmenntafélag, 1974-90), V (1990), pp. 3-216 (p. 101).

110 'pótti hann í sínu valdi vera ok undan genginn fyrir vanrækt Auðunar byskups', Lárentíus saga, p. 371.

${ }^{111}$ Lárentíus saga, p. 371, no 1.
} 
as bishop, Lárentius visited Grenjaðastaðir, along with the other major churches of Hólar. There he discovered that in Bishop Auðunn's absence, the officialis Porsteinn Illugason had appointed Jón Koðránsson to Grenjaðastaðir, and, as bishop-elect, 'assigned it there to him [Jón Koðránsson] also, when he should come back from Norway'. ${ }^{112}$ The wording is somewhat unclear, but suggests that Lárentius had agreed to confirm Jón's appointment after he had been fully consecrated as bishop. It was one of the duties of the officiales to appoint priests to vacant benefices in the absence of the bishop, although it is possible that these appointments were always subject to the approval of the incoming bishop. ${ }^{113}$ Archbishop Eilífr's reasoning here is thus somewhat suspect; although it was true that Bishop Auðunn had neglected to appoint an incumbent before his death, the situation had been appropriately dealt with by his appointee and his successor. Egill's later career suggests that he had strong connections in Niðarós; his appointment to Grenjaðastaðir here suggests the same. It cannot, however, be taken as normal procedure.

Another instance of archiepiscopal presentation can be found in Árna saga. During one of Bishop Árni's stays in Norway in 1289, the bishop learned from his follower Jón holt that Archbishop Jörundr had given Oddi, the most important benefice in Skálholt, to a priest named Guðmundr Hallsson. His response was described as follows:

The bishop [Árni] made himself very heavy with that [he worried about it] and one day they both [Árni and Guðmundr Hallsson?] went to the archbishop in his bedroom [...] Bishop Árni asked the archbishop whether he had given Oddi before he left from Vík, the staðr which he [Árni] had previously given to Grímr Hólmsteinsson and before that had won from laypeople. The archbishop said it was true but said that he did not know that this staðr had already been given and says that the gift was void for this reason. The archbishop was displeased with Síra Guðmundr on account of this report, although he allowed Bishop Árni to give him Breiðabólstaður [í Fljótsdal].

Byskup gerði sik mjök pungan við petta, ok einn dag gengu peir báðir til erkibyskups í svefnstofu hans [...] Árni byskup spurði erkibyskup hvárt hann hefði gefit Oddastað áðr hann fór af Víkinni, pann sem áđr hefði hann gefit Grími Hólmsteinsson en fyrrum sótt af leikmönnum. Erkibyskup segi petta satt vera en léz eigi vita at pessi staðr var áðr gefinn, ok segir at gjöfin var lauss fyrir pessa skynsemi. Mislíkaði erkibyskupi við

\footnotetext{
112 'skipaði electus ok honum par allt sem hann kæmi aftr af Nóregi', Lárentíus saga, p. 356.

113 The wording of the annals at the arrival of a new bishop suggests that he had the power to remove priests from their offices (see above). A few letters exist from bishops confirming the judgements of their officiales; see for instance, DI III, pp. 199-200.
} 
síra Guðmund um penna flutning, pó lét hann Árna byskup gefa honum Breiðabólstað. ${ }^{114}$

This account could be read as evidence for archiepiscopal presentation in the fourteenth century. The archbishop here first presented Guðmundr Hallsson with the benefice of Oddi, and relented only after discovering that it had already been given. Moreover, his permission appears to have been required for Bishop Árni then to give the benefice of Breiðabólstaður í Fljótsdal to Guðmundr. However, an alternate reading is also possible. These events took place only a few years after Bishop Árni won Oddi from its lay owners in 1272, and in the middle of the staðamál conflict which gave Bishop Árni the right to present the staðir to elite priests as gifts. Moreover, Guðmundr Hallsson was Bishop Árni's follower, and supported the bishop against the archbishop, even though it meant losing Oddi. Moreover, Bishop Árni's strong reaction to the news, as well as his reminder to the archbishop that it was he who had won the staðr at Oddi from its lay owners, suggest a political battle. Rather than definitive evidence of archiepiscopal presentation, this scene appears to represent an attempt by the archbishop to encroach on the bishops' right of presentation. By reacting strongly and quickly to this attempt, Bishop Árni was able to reassert his right to appoint priests even to the wealthiest benefices in Iceland. ${ }^{115}$ This conclusion is strengthened by the conclusion that the archbishop was displeased with Guðmundr Hallsson, since his attempt to take control of the presentation of Oddi failed in part because of Guðmundr. While it may have been the case by the fifteenth century that the largest benefices in Iceland had become archiepiscopal benefices, no fourteenth-century evidence supports the theory that these benefices were in the gift of the archbishop at this time.

\subsection{Elite Identity: Clerical Identity}

Orri Vésteinsson has argued persuasively that the Church did not exist as a fully developed institution when Christianity first came to Iceland in the year 1000 . He

\footnotetext{
${ }_{114}^{11}$ Árna saga, p. 200.

115 For an alternate reading of this episode, however, see Magnús Stefánsson, 'Frá goðakirkju til ríkiskirkju', p. 217. He argued here that since the staðamál conflicts were not yet settled, Bishop Árni recognised the archbishop's right to gift any empty churches or staðir in Iceland.
} 
suggested that over the course of the next several centuries, the clergy developed a distinct clerical identity, rooted in the Church. ${ }^{116}$ Part of this distinct clerical identity consisted of a description of uniquely clerical culture, such as their role as peacemakers, clerical celibacy, and identification with the Church before all other ties. ${ }^{117}$ We have seen how the secular clergy in the fourteenth century prioritised connections within the Church, particularly ties with bishops and other members of the elite beneficed clergy, and it seems right to conclude that these relationships were valued by the clergy over ties to family and the secular aristocracy. At the same time, however, clerical identity cannot be reduced to simple adherence to ecclesiastical principles. Although the enforcement of these markers of clerical exceptionalism (and here I am thinking specifically of peacemaking and clerical celibacy) were significant developments of the thirteenth century in Iceland, recent scholarship has begun to question the practical application of these prohibitions. Some scholars have begun to remark, for instance that clerical concubinage in Iceland was both widespread and commonly accepted. ${ }^{118}$ In relation to clerical pacifism, the Norwegian historian Torstein Jørgensen is currently researching instances of violent crime among the clergy in late medieval Norway. His preliminary findings suggest that it was far more common for clerics to carry weapons, and use them, than has previously been thought. ${ }^{119}$ This research is still in a very early stage of development, but the evidence presented so far suggests a much more complicated picture of clerical identity than formal adherence to canon law. In the case of the sub-episcopal elite in Iceland, the canonical irregularities (concubinage and clerical violence) cannot be understood simply as transgressions. On the contrary, they contributed to the development of personal networks and relationships between individual members of the clergy through mechanisms such as the fosterage of the children of clerics, and the creation of communities based on conflict.

\footnotetext{
${ }^{116}$ Orri Vésteinsson, The Christianization of Iceland, pp. 209-37.

${ }_{117}$ Orri Vésteinsson, The Christianization of Iceland; on peacemaking, see pp. 209-34; on clerical celibacy, see pp. 234-37.

${ }^{118}$ See for example Agnes Arnórsdóttir's account in Marriage and Virginity, pp. 260, 40002 .

119 'Law and Violence in the Middle Ages', see the project website, available at: < http://www.wun.ac.uk/external/lvma/index.html> accessed 9 November 2011.
} 


\subsubsection{Clerical Concubinage, Fostering, and the Children of Clerics}

Clerical marriage was abolished in Iceland in the second half of the thirteenth century, following archiepiscopal statutes and episcopal campaigns from c. 1237 to the 1260s and 1270s. ${ }^{120}$ As Bishop Auðunn's strategic use of dispensations for defect of birth makes clear, however, priests continued to have concubines and father children. In Iceland, perhaps more than elsewhere, clerics continued to keep these relationships quite openly. Bishop Auðunn (1313-22) and Bishop Lárentius (132431) of Hólar both had children quite openly; Auðunn brought his grandson to Hólar with him and Lárentius brought his son Árni with him, first into monastic orders, and later to the bishopric of Hólar, where Árni served as one of the bishop's clerks. Clerical concubinage in Iceland has not yet been studied in any detail, but would reward further study. In particular, it is interesting to note that the women involved with priests in Iceland appear to have benefitted from a higher degree of social and economic stability than their European counterparts. ${ }^{121}$ The children of clerics, too, benefited from a high degree of social acceptance and economic stability. ${ }^{122}$ Indeed, the children of clerics, particularly through their education, appear to have been a method of strengthening ties between members of the clerical elite.

The passage in Lárentíus saga describing Bishop Auðunn's granting of dispensations is the only explicit mention of a bishop granting dispensations for the sons of clerics to become ordained priests. However, it is one of many examples of clerics taking interest in the clerical education of the sons of their friends, and sometimes enemies. It is well-known that chieftains in Iceland during the Commonwealth period made use of a process of fostering other families' children in

\footnotetext{
${ }^{120}$ Orri Vésteinsson, The Christianization of Iceland, p. 234.

${ }^{121}$ I am thinking here particularly of a facinating collection of letters documenting the economic transactions between Pórðr Pórðarson and his concubine, Valdís Helgadóttir, DI III, pp. 501-02, 576-78, 683, 778.

${ }^{122}$ On the children of clerics in the European context, see Bernhard Schimmelpfennig, ' $E x$ fornicatione nati: Studies on the Position of Priests' Sons from the Twelfth to the Fourteenth Century', Studies in Medieval and Renaissance History, 2nd series, 2 (1979), 3-50; and Kathryn Ann Taglia, "“On Account of Scandal...": Priests, Their Children, and the Ecclesiastical Demand for Celibacy', Florilegium, 14 (1995-96), 57-70. On sons of clerics in holy orders, see especially Ludwig Schmugge, Kirche, Kinder, Karrieren: Päpstliche Dispense von der unehelichen Geburt im Spätmittelalter (Zürich: Artemis \& Winkler, 1995).
} 
order to strengthen bonds of friendship. ${ }^{123}$ It is possible that taking on the clerical education of the sons of other families played a similar role among the clerical elite in late medieval Iceland.

A document from 1385 records the sale of the manor at Ásgeirsá to Jón Hákonarson by his uncle Magnús Gizzurarson in that year. The manor sold for sixty hundráð, but the contract also included the stipulation that Jón Hákonarson would provide for Magnús' son Hallkell:

that the previously-mentioned Jón shall take on Hallkell, their son, and have him educated to be a priest, so that he should be made properly capable of taking up that office, and [Jón] shall give him [Hallkell] a chalice, and shall receive with him twenty hundrád from the worth of the described properties, half of which shall be in kúgildi and wares.

at prattnefndr jon skýllde taka at ser hallkel son peirra oc lata kenna honum til prestz sva hann se sæmiligha fæir til pess embættis oc fa honum kalek oc taca med honum tuttugu hundrut af greindu jardar verdi halft huort kugillde oc vauru. ${ }^{124}$

It is possible that Hallkell's parents, fallen on hard times, would have been unable to provide him with an expensive clerical education without this agreement with their nephew, Jón Hákonarson. However, the provision providing for Hallkell's education as a priest may also have been intended as a way of bringing Hallkell to the attention of his much wealthier and more prominent relative. By providing for his education, Jón may have been intended as a patron of his young relative. Nothing is known of the future career of Hallkell Magnúsarson; whether through accident or a lack of opportunities, this lack of a record of his career might suggest that he did not rise to the levels of the elite clergy under discussion here.

The provision for Hallkell is the only example in the documentary material of an agreement to provide for the clerical education of another's son, but there are a few comparable examples from the bishops' sagas. In Árna saga, Bishop Árni became embroiled in a lengthy personal dispute with Ásgrímr Porsteinsson, a secular official who supported the farmers during the staðamál, and tried to tax the people of Skálholt for the king. On his deathbed, Ásgrímr settled with Bishop Árni, who

\footnotetext{
${ }^{123}$ William Ian Miller, 'Choosing the Avenger: Some Aspects of the Bloodfeud in Medieval Iceland and England', Law and History Review, 1 (1983), 159-204 (pp. 166-67); see also Jón Viðar Sigurðsson, Chieftains and Power, p. 144.

${ }^{124}$ DI III, p. 383.
} 
responded by providing Ásgrímr with a fitting burial at Skálholt, conducted by the bishop himself, and 'a little while later, the bishop took to himself Porsteinn, the son of Ásgrímr, and had him taught till such a time as he [Bishop Árni] gave him [Porsteinn] a priests' ordination'. ${ }^{125}$ Árni's decision to teach Porsteinn and support him until he should be ordained as a priest, together with Árni's gracious attendance to Ásgrímr's burial, showed Bishop Árni’s reconciliation with Ásgrímr after his death. By bringing Ásgrímr's son into the Church, Árni did more than provide for Porsteinn; he demonstrated the victory of the Church over secular officials by bringing the son of a prominent secular official into the Church.

An episode in Lárentíus saga shows again the use of descendents in cementing or making visible relationships. In the saga, a conflict between Lárentius and Bishop Auðunn, the bishop of Hólar, was resolved through the intervention of their mutual friend, Egill Eyjólfsson. After their settlement, it was agreed that 'Lárentius should teach the grandson of the bishop, who was called Eysteinn; he went with Brother Lárentius and he taught him'. ${ }^{126}$ Here too, Eysteinn became the symbol of the reconciliation between Auðunn and Lárentius; unlike the similar incident in Árna saga, in which Bishop Árni educated the son of a converted rival as a sign of his victory, in this instance Bishop Auðunn's giving of his grandson to be educated showed his continuing superiority.

Lárentius educated a large number of the elite clerics who would later rise to prominence, including Einarr Hafliðason, the author of the saga. Lárentíus saga makes clear that Einarr himself remained loyal to Lárentius, and valued the loyalty of a pupil to his master. Moreover, the saga is particularly explicit about Lárentius' friendship with Einarr's father Hafliði. Its first description of Hafliði, for instance describes him as his [Lárentius'] dear friend, the Reverend Hafliði', who cared for Lárentius' mother and arranged her burial, 'then when Lárentius was most oppressed by his enemies'. ${ }^{127}$ It is possible that by taking on the education of Einarr, Lárentius further solidified his own friendship with Einarr's father Hafliði. These few recorded

\footnotetext{
125 'Litlu síðar tók herra byskup til sín Porstein, son Ásgríms, ok lét kenna honum til pess er hann gaf honum prestsvígslu', Árna saga, p. 141.

126 'Skyldi bróðir Laurentius kenna dóttursyni herra byskups er Eysteinn hét; fór hann með bróður Laurentio, ok kenndi hann honum', Lárentíus saga, p. 338.

127 'hans kæri vinr, síra Hafliði'; 'pá er Laurentius var mest fyrir lagðr af sínum óvinum', Lárentíus saga, pp. 218-19.
} 
instances serve to suggest that one possible way of creating or strengthening ties between clerics was through teaching or providing for the son of the other.

These case studies are enough to suggest that the education of the children of clerics, as well as that of the children of secular elites destined for the clergy could be used as a tool to create or maintain complex relationships between the father and the teacher, as well as between teacher and pupil. The two detailed stories discussed above were both from bishops' sagas, and the case study regarding the sons of clerics was from Lárentíus saga, itself written by the son of a cleric. It is important to bear in mind, however, that the evidence on the children of clerics in Lárentius saga differs significantly from that of non-narrative sources. Lárentíus saga provides only one instance of a clerical child not in holy orders, Ólöf the daughter of Bishop Auðun. She, however, is mentioned in the saga primarily as the mother of Eysteinn rauði, who followed his grandfather and became a prominent cleric, as described above (see also Chapter 5.2.1). Documentary evidence, on the other hand, provides numerous examples of children of clerics in non-clerical positions. In fact, while Einarr Hafliðason was himself the son of a cleric, and indeed, inherited his benefice, Breiðabólstaður í Vesturhópi from his father, his own son Árni did not join holy orders (see table 2, below). Non-ordained children could also help foster connections and personal networks, through marriage contracts, property ownership, and other forms of engagement with the secular elite. These connections have not yet been studied. To illustrate the range of known data on the children of priests, I have provided below two tables of children of clerics, one from annals and documentary material, the other from Lárentíus saga. The comparison shows how narrow the evidence of Lárentíus saga is; on the other hand, annals and documents give very little evidence for the ordained sons of priests, as Lárentíus saga does. ${ }^{128}$

\footnotetext{
${ }^{128}$ However, they do provide some evidence in the form of personal names. See Table 6 (Killings of Priests), no. 152.
} 
Table 4. Clerics with children: $1380-1405^{129}$

\begin{tabular}{|c|c|c|c|c|}
\hline Name & Partner & Benefice & Children & $\begin{array}{l}\text { Type and Date of } \\
\text { document }\end{array}$ \\
\hline $\begin{array}{l}\text { Ásgrímr } \\
\text { Guðbjartsson }\end{array}$ & - & - & $\begin{array}{l}\text { Guðbjartr, } \\
\text { Erlendr }\end{array}$ & $\begin{array}{l}\text { confirmation of } \\
\text { gift, } 1380\end{array}$ \\
\hline Sölvi Brandsson & - & $\begin{array}{l}\text { unknown } \\
\text { (owned land in } \\
\text { Hrútafjörðr) }\end{array}$ & $\begin{array}{l}\text { Brandr, } \\
\text { Guðríðr [?], } \\
\text { Porgerðr [?] }\end{array}$ & $\begin{array}{l}\text { gift, } 1391, \\
\text { marriage } \\
\text { contract, } 1402\end{array}$ \\
\hline $\begin{array}{l}\text { Einarr } \\
\text { Hafliðason }\end{array}$ & - & $\begin{array}{l}\text { Breiðabóls- } \\
\text { staður í } \\
\text { Vesturhópi }\end{array}$ & Árni & annal,1391-93 \\
\hline Páll Porsteinsson & - & $\begin{array}{l}\text { ráðsmaður at } \\
\text { Reynistaðr }\end{array}$ & Runólfr & $\begin{array}{l}\text { annal (record of } \\
\text { inheritance } \\
\text { dispute, 1391-93 }\end{array}$ \\
\hline Guðmundr & - & $\begin{array}{l}\text { unknown } \\
\text { (owned land in } \\
\text { Hörgárdalr) }\end{array}$ & Einarr & sale, $1399-1400$ \\
\hline $\begin{array}{l}\text { Steinmóðr } \\
\text { Porsteinsson }\end{array}$ & $\begin{array}{l}\text { unnamed } \\
\text { daughter of } \\
\text { Eiríkr } \\
\text { Magnússon }\end{array}$ & $\begin{array}{l}\text { Grenjaða- } \\
\text { staðir }\end{array}$ & $\begin{array}{l}\text { sons, } \\
\text { unnamed }\end{array}$ & $\begin{array}{l}\text { inheritance case } \\
\text { (1415) }\end{array}$ \\
\hline $\begin{array}{l}\text { Halldórr } \\
\text { Loptsson }\end{array}$ & $\begin{array}{l}\text { Gýða } \\
\text { Salomonsdóttir }\end{array}$ & {$[?]^{130}$} & $\begin{array}{l}\text { Ingrid, Helga, } \\
\text { Cecilia, } \\
\text { unborn baby }\end{array}$ & will (1403) \\
\hline $\begin{array}{l}\text { Einarr } \\
\text { Porvarðsson }\end{array}$ & - & & $\begin{array}{l}\text { Magnús, } \\
\text { Arngrímr, } \\
\text { Guðrún }\end{array}$ & Adoption case \\
\hline $\begin{array}{l}\text { Guðmundr } \\
\text { Porsteinsson }\end{array}$ & 一 & $\begin{array}{l}\text { Valpjólfs- } \\
\text { staður }\end{array}$ & Sigríðr & $\begin{array}{l}\text { marriage contract } \\
(1405)\end{array}$ \\
\hline Pórðr Pórðarson & $\begin{array}{l}\text { Valdís } \\
\text { Helgadóttir }\end{array}$ & $\begin{array}{l}\text { Without named } \\
\text { children } \\
\text { Höskulds- } \\
\text { staður }\end{array}$ & - & contract (1401) \\
\hline
\end{tabular}

${ }^{129}$ DI III, pp. 349-50, 454-55, 642-43, 666-67, 669, 676-78, 679, 684-88, 705-06, 761-62, Flateyjarannáll, pp. 417-18, 419.

${ }^{130}$ See section 4.2.2. 
Table 5. Clerics with children (Lárentíus saga) ${ }^{131}$

\begin{tabular}{|c|c|c|c|c|}
\hline Name & Partner & $\begin{array}{l}\text { Position/ } \\
\text { Benefice }\end{array}$ & Children & $\begin{array}{l}\text { Children's } \\
\text { position/benefice }\end{array}$ \\
\hline & & & $\begin{array}{l}\text { ordained } \\
\text { sons }\end{array}$ & \\
\hline Hafliði Steinsson & $\begin{array}{l}\text { Rannveig } \\
\text { Gestsdóttir }\end{array}$ & $\begin{array}{l}\text { Breiðabólstaður } \\
\text { í Vesturhópi }\end{array}$ & Einarr & $\begin{array}{l}\text { Höskuldsstaðr, } \\
\text { Breiðabólsstaður } \\
\text { í Vesturhópi }\end{array}$ \\
\hline Porsteinn & - & unknown & Páll & $\begin{array}{l}\text { ráðsmaðr at } \\
\text { Reynistaðr }\end{array}$ \\
\hline Hallr & - & unknown & Porsteinn & priest, unknown \\
\hline Porkell & - & unknown & Pormóðr & priest, unknown \\
\hline Kóðrán Hranason & - & $\begin{array}{l}\text { priest } \\
\text { Grenjaðastaður } \\
\text { (before 1313- } \\
15 \text { ) }\end{array}$ & Jón & $\begin{array}{l}\text { priest, } \\
\text { Grenjaðastaðir } \\
(1321), \text { Hrafnagil } \\
(1324-)\end{array}$ \\
\hline Lárentius Kalfsson & $\begin{array}{l}\text { Puríðr } \\
\text { Árnadóttir } \\
\text { from } \\
\text { Borgund, } \\
\text { Norway }\end{array}$ & $\begin{array}{l}\text { chaplain at } \\
\text { Niðarós, monk } \\
\text { of Pingeyri, } \\
\text { bishop of Hólar }\end{array}$ & $\begin{array}{l}\text { other } \\
\text { children } \\
\text { Árni }\end{array}$ & monk at Pingeyri \\
\hline Auðunn Porbergsson & - & $\begin{array}{l}\text { canon of } \\
\text { Niðarós, bishop } \\
\text { of Hólar }\end{array}$ & Ólöf & $\begin{array}{l}\text { married Porsteinn } \\
\text { bóndi, later } \\
\text { Klemet bóndi }\end{array}$ \\
\hline
\end{tabular}

131 Lárentíus saga, pp. 258-59, 318, 319-20, 329-30, 439; DI II, pp. 744, 789; Lögmannsannáll, p. 275. 


\subsubsection{Clerical Violence and Conflict}

In 1328, at the height of the Möðruvallamál (the Möðruvellir case), Bishop Lárentius decided to ride to Möðruvellir, to inspect the monastery, particularly its finances. Before coming to this decision, Lárentius had been greatly troubled by the fact that the layman Uppsala-Hrólfr had been staying at Möðruvellir with his followers, at the monastery's expense. Upon his arrival at Möðruvellir, the bishop was greeted by the following:

There were before [him] no fewer than forty men: Uppsala-Hrólfr and the farmers from Hörgárdalur and Eyjafjörður. There was no procession (processia) made to meet the bishop, but the above-mentioned farmers stood there with weapons. The bishop and his followers went first to the church; none of the said brothers acknowledged the bishop. The bishop sat at mealtime in the Big Room (poss. the refectory); it was arranged that the farmers sat on one bench, and the bishop and his followers on the other; entirely choicer food was given to the farmers by the brothers than to the bishop and his followers. The bishop stayed there one night, he did not speak with the brothers, nor they with him.

vóru par fyrir eigi færri en fjörutigir manns; Uppsala-Hrólfr ok bændr af Hörgárdal ok Eyjafirði. Engin processia var gjör á móti byskupi, en bændr fyyrsagðir stóðu par með vápnum. Byskup ok hans menn gengu fyrst til kirkju; varð ekki af kveðjum bræðra við byskup. Sat byskup at máltíð í Miklustofu; var svá skipat at bændr sátu á annan pall en byskup ok hans menn á annan; var bændum gefinn af bræðrum allr fríðari kostr en byskupi ok hans mönnum. Sat byskupinn par eina nótt, talaði hann ekki við bræðrum ok eigi peir við hann. ${ }^{132}$

What is remarkable about this passage is the show of strength and the implied violence of this display. The bishop was met by forty armed men, who stood in front of the friary as the bishop attempted to enter, and sat facing Lárentius and his party as they ate. Although there was no actual fighting, the message is one of implied violence; Lárentius left without speaking to the brothers because he was outnumbered, and the laypeople's actions suggested that they would meet any overture on his part with violence. There is no indication that the friars would have engaged in armed violence themselves; instead, they recruited laypeople to intimidate and bully the bishop and his party.

Lárentius, however, responded in kind. He left the friary, making the friars believe that he would not be returning. Instead of following his stated plan, he

${ }^{132}$ Lárentíus saga, pp. 418-19. 
returned unannounced after the friars had turned away the crowd of laypeople. Like the friars, Lárentius had his own friends among the laity; on this visitation, we learn, the bishop had with him Benedikt Kolbeinsson and his servants (sveinar, which could imply armed followers). ${ }^{133}$ On this visit, Bishop Lárentius walked straight into the chapter, and demanded of the prior Pórgeirr that he hand over the key to the stores, so that the bishop might inspect them. When the prior refused, Lárentius, 'then had learned men (i.e. clerics) take the key from him by force'. ${ }^{134}$ Upon discovering that the stores were poorly kept, Lárentius unilaterally appointed a new ráðsmaðr to look after the goods, and also appointed a new prior, 'Prior Pórgeirr, he had with him by force'. ${ }^{135}$

What stands out in these two passages is the violence and implied violence involved in this dispute between bishop and friary. Particularly interesting is the recruitment on both sides of laypeople as the armed enforcers in primarily clerical disputes. There is no indication that either the friars or Bishop Lárentius would have engaged in armed violence themselves; instead, each side recruited laypeople to intimidate and bully the other. The laypeople were involved through their previous ties. Benedikt Kólbeinsson and his family were closely tied to Bishop Lárentius, while the farmers of Eyjafjörður had a close relationship with the friary of Möðruvellir. ${ }^{136}$

Lárentíus saga makes strong use of parallelism, and there is an earlier parallel to this story about Lárentius' dispute with the friars of Möðruvellir. In 1318, Bishop Auðunn rauði found himself in a dispute with the abbot and monks of Pingeyri over a portion of the bishop's tithes, which the monastery claimed. During a visitation around the western part of the diocese, Bishop Auðunn attempted to visit Pingeyri, with the following consequences:

Lord Auðunn visited in the fall around the western district, and when he rode from Breiðabólstaður to Pingeyri, the brothers closed the monastery before Bishop Auðunn; they formed no procession to meet him. His people were served food, and he himself

\footnotetext{
${ }^{133}$ Lárentíus saga, p. 419.

134 'Lét hann pá lærða menn taka lykla burt af peim nauðgum', Lárentíus saga, p. 419.

135 'Prior Porgeirr hafði hann með sér nauðugan', Lárentíus saga, p. 420.

${ }^{136}$ Benedikt's aunt Hallbera was the abbess of Reynistaður and a dear friend to Bishop Lárentius; see Lárentíus saga, pp. 385-86. On the relationship between Möðruvellir and the farmers of Eyjafjörður (as well as Einarr Hafliðason's take on both) see Lögmannsannáll, p. 278; see also Chapter 2.4. Lárentíus saga also specifies that Prior Porgeirr was patronising Uppsala-Hrolfr and his followers shortly before this conflict, p. 415.
} 
as well, but no beer. Síra Hafliði had his own beer brought forth, and Bishop Auðunn and his people drank that. Brother Björn Porsteinsson was prior of the monastery and the staðr. ${ }^{137}$ Many farmers had come from Vatnsdalur in order to defend the monastery from the bishop if he wanted to attack it at all. He did not look likely to do so, nor did any of his people.

Visiteráði herra Auðun um haustit um vestrsveitir, ok sem hann reið frá Breiðabólstaður til Pingeyra byrgðu bræðr klaustrit fyrir Auðuni byskupi. Enga processio gjörði peir í mót honum. Matr var hans mönnum til reiðu ok svá honum sjálfum en ekki öl. Lét síra Hafliði bera fram sitt öl ok pat drakk Auðun byskup ok hans menn. Bróðir Björn Porsteinsson var prior fyrir klaustrinu ok staðnum. Var mart bænda komit ofan ór Vatnsdal til pess at verja klaustrit fyrir byskupi ef hann vildi nokkot á sækja; gjörði hann sik ekki líklegan til pess ok engi hanns manna. ${ }^{138}$

The passages show a number of similarities, as Guðrún Ása Grímsdóttir has noted. ${ }^{139}$ In both cases, the monasteries showed resistance primarily by withholding signs of welcome; they did not come out to greet the bishop, and they showed him markedly poor hospitality. The friars of Möðruvellir also refused to speak to the bishop, and the monks at Pingeyri refused to allow him entry. In both passages as well, however, the real defence came from the laypeople of the district, who came to the monastery to defend it. In the first passage, it was specified that the farmers and their followers were armed; it could be assumed that the farmers of Vatnsdalur were also armed, or using the threat of violence to defend the monastery.

Violence against clerics is in fact a recurring theme in Lárentíus saga, although it most often takes the form of brawling or threats, rather than attacks with weapons or killings. Early in the saga, when a young Lárentius read the ban of excommunication against the farmer Sigurðr, who held the church property of Möðruvellir, the case ended in threats of violence: 'Lárentius got from Sigurðr and his followers many abusive words and threats, so far that it ended that it was scarcely possible for him to walk out of the church unscathed' ${ }^{140}$ For his role in the conflict between Archbishop Jörundr of Niðarós and the canons, Lárentius faced daily threats and attempted beatings from the followers of the canons. ${ }^{141}$ Finally, during the course of his time as visitor in the diocese of Hólar, Lárentius embroiled himself in a

137 Guðmundr, the abbot, had traveled to Norway the summer before to seek the archbishop's support in this case. Lárentíus saga, p. 335.

${ }^{138}$ Lárentíus saga, p. 335.

${ }^{139}$ Ibid., p. 335, no. 3.

140 'Fekk Lárentius af Sigurði ok hans mönnum mörg atyrði ok hótanarorð svá viðr pví var búit at honum mundi varla óhætt ganga út af kirkjunni', Lárentíus saga, p. 234.

${ }^{141}$ Lárentíus saga, pp. 249, 251-52. 
dispute between a parish priest and the monks at Munkapverá over burial rights. In the course of the conflict, Lárentius wrote a letter forbidding the monks there to sing Mass as long as they continued to hold the disputed body. When the bishop's messenger, Snjólfr Sumarlíðson came to Munkapverá, he read a letter from the bishop, saying that the monks were not forbidden to perform Mass.

Snjólfr demanded that Lárentius have his writ of arbitration read out. Lárentius read the letter and when he had come to the end of the letter, the abbot grabbed for the letter in the church, and many people with him: they ripped the letter apart and tore the seal from it. Then they [Lárentius and his followers] were dragged and pulled from the church and the churchyard, although there was no more harmful fighting. Lárentius was shown such violence that it was unclear whether he would have received harm if Lord Pórðr had not offered him help and support.

Krafði Snjólfr Laurentium at láta lesa órskurðarbréf sitt ok eftir pat las Laurentius bréfit ok sem komit var at enda bréfit greip ábóti til bréfsins í kirkjunni ok margir menn með honum; rifu peir í sundr bréfit ok frá innsiglit. Vóru peir siðan dregnir ok hrundnir út af kirkjunni ok kirkjugarðinum, en engi meiri handatiltæki urðu par mönnum til skaða. Var Laurentius svá afli borinn at tvísýnt var at hann mundi ei skaða af fengit ef herra Pórðr hefði eigi honum hjálp ok styrk veittan. ${ }^{142}$

Here again, we see an instance in which a monastery used violent resistance to achieve its ends. Unlike the carefully orchestrated shows of strength visible in the previous examples, this brawl appears not to have been premeditated on the part of the abbot. Instead, the brawl was provoked by Sjnólfr's insistence that Lárentius read out his inflammatory letter; from subsequent descriptions of Snjólfr's character and his role in the conflict, it is clear that this provocation was deliberate. ${ }^{143}$ The abbot and the monks' anger with Lárentius was thus exploited here by Snjólfr, who provoked them to violence in order to undermine Lárentius' authority. The fact that Snjólfr could count on their anger turning to violence, and that their attack on Lárentius could leave him in fear of serious injury, suggests that violence was not an uncommon occurrence in clerical circles, and that monks and priests were not as far removed from the violence of Icelandic society as their profession dictated.

The annals also offer instances of violence among the monks and clerics of Iceland. In 1343, the newly-arrived Bishop Jón Sigurðsson imprisoned three monks

\footnotetext{
${ }^{142}$ Lárentíus saga, p. 281.

${ }^{143}$ Ibid., p. 281; at multiple points in Lárentius' later career, his relationship with Sjnólfr is portrayed as being marked by bitterness and mutual resentment, see pp. 361, 388-89.
} 
from Pykkvibær for having beaten their abbot. ${ }^{144}$ The annals record several instances of clerics having been killed or died of their wounds. I have presented these records in tabular form below (Table 4). Together, they show that from 1333 to 1377, seven incidents were recorded in which a priest or cleric in minor orders was killed or wounded. One, a deacon named Sigurðr, was killed at a priests' synod at Skálholt, and one source, Gottskálksannáll, claimed that the leader of his attackers was a subdeacon named Sokki (see Table 4). While the evidence is only fragmentary, it certainly suggests that clerics were both the victims and sometimes the aggressors in violent assaults.

Flateyjarannáll reports in some detail on the conflict between Björn Einarsson jorsalafari and Pórðr Sigmundarson. In 1394, Björn rode to meet Pórðr to demand compensation for the deaths of two of Björn's followers in a previous battle. Björn was supported by the hirðstjóri (governor) Vigfús Ívarsson, the lögmaðr (lawman) Porsteinn Eyjólfsson, the wealthy aristocrats Jón Hákonarson and Benedikt Gizzurarson, as well as the priests Pórðr Pórðarson and Halldórr Loftsson, 'and nearly ninety men, most of them protected by armour, helmets and gauntlets'. ${ }^{145}$ Although the standoff ended with a settlement, Pórðr Pórðarson and Halldórr Loftsson, two of the most powerful priests in the district, were part of a heavily armed party, coming out clearly on the side of Björn Einarsson.

As discussed above, Orri Vésteinsson has argued that in the thirteenth century, clerics developed an identity as peacemakers and mediators in the conflicts of laypeople. ${ }^{146} \mathrm{He}$ charted a drop in the number of priests and clerics killed in violent conflict, and argued that over the course of the thirteenth century, priests ceased to take sides in disputes between lay aristocrats as their allegiances shifted from lay patrons to their bishops. ${ }^{147}$ To a limited extent, fourteenth-century evidence supports these conclusions. The evidence from Lárentíus saga suggests that monks and clerics were willing to make use of lay supporters for their show of force; they were portrayed engaging in brawls and the violent overpowering of Prior Pórgeirr, but not as engaging in armed violence. Moreover, the language of the annals

\footnotetext{
144 'Jonn byskup fangadi Arngrim Eystein ok Magnus brædr i Pyckua bæ fyrir pat er peir hofdu bart a Porlaki abbota sinum', Flateyjarannáll, p. 402.

145 'ok nær niu tigum mann.e ok flestir allir tyiadir panzserum iarnhattum ok vopnhanzskum', Flanteyannáll, p. 424.

${ }^{146}$ Orri Vésteinsson, The Christianization of Iceland, pp. 209-34.

${ }^{147}$ Ibid., see especially figure 10, p. 214.
} 
suggests that in the eyes of the annalists, at any rate, the killing of a cleric was a particularly heinous crime. At the same time, however, it is important to note that in many cases the prohibition on clerics carrying weapons and using violence appears to have been respected in letter, but not in spirit. In conflicts between clerics, as the evidence from Lárentíus saga suggests, members of the clergy used physical violence and the threat of physical violence, either by gaining the support of powerful laypeople who would fight for them, or in some cases by brawling. Crucially, the evidence of Lárentíus saga suggests that acts such as brawling, threats of violence, and the use of armed laypeople to intimidate or attack one's opponents were not simply transgressions of clerical prohibitions on violence, but rather were legitimate tactics in clerical disputes. As Otto Brunner's study on feuding in Continental Europe has shown, conflict conducted according to the proper rules can be as important in developing a sense of shared identity as friendship. ${ }^{148}$ Clerical violence, and particularly violence in conflicts between the bishop and the monasteries, appears to have served the same purpose, creating a clerical network of both allies and antagonists. While this network had a place for the secular aristocracy, its focus was entirely clerical.

${ }^{148}$ Brunner, Land and Lordship. See also Chapter 1.3.2. 
Table 6. Killings of priests (Icelandic Annals): 1300-1400 149

\begin{tabular}{|c|c|c|c|}
\hline Name & Year & Benefice/Position & $\begin{array}{l}\text { Context of killing (if } \\
\text { known) }\end{array}$ \\
\hline Benedikt Sölmundarson & 1333 & Oddi & $\begin{array}{l}\text { died of wounds } \\
\text { inflicted } 1331 \text { by Páll } \\
\text { Pórisson }\end{array}$ \\
\hline 2 unnamed clerks & 1333 & - & $\begin{array}{l}\text { battle between clerks } \\
\text { and tanners (Norway) }\end{array}$ \\
\hline Porbjörn Porsteinsson & 1334 & Kirkjuvogur/Nes & killed at the altar \\
\hline Ásgrímr (wounded only) & 1334 & Vatnsfjörðr & $\begin{array}{l}\text { wounded in the } \\
\text { churchyard by } \\
\text { Porarin pentr } \\
\text { Eiríksson }\end{array}$ \\
\hline $\begin{array}{l}\text { Porsteinn butr Pálsson } \\
\text { (wounded) }\end{array}$ & 1338 & $\begin{array}{l}\text { Holt í } \\
\text { Önundarfirði, } \\
\text { provost of the } \\
\text { Westfjords }\end{array}$ & $\begin{array}{l}\text { wounded during an } \\
\text { escape (?) at Pingeyri } \\
\text { in Dyrafjörðr }\end{array}$ \\
\hline Sigurðr Ásgrímsson ${ }^{151}$ & 1357 & deacon & $\begin{array}{l}\text { killed at a priests' } \\
\text { synod at Skálholt }\end{array}$ \\
\hline Nikulás Porsteinsson ${ }^{152}$ & 1377 & Holt í Önundarfirði & - \\
\hline
\end{tabular}

${ }^{149}$ Storm, Islandske Annaler, pp. 206, 207, 225, 271, 281, 348, 349, 350, 363-64, 356, 398, 399, 406, 412; DI II, pp. 723-24, 731.

${ }^{150}$ The annal is unclear whether Porsteinn butr Pálsson was wounded by an attack or whether he was injured escaping some natural disaster, such as an avalanche.

${ }^{151}$ Gottskálksannáll reports that Sigurðr was an acolyte, and that the leader of his attackers was a subdeacon named Sokki.

152 This priest's patronymic provides another clue that the inheritance of benefices was a common practice, as both Porsteinn butr Pálsson and Nikulás Porsteinsson held Holt í Önundarfirði, a fairly wealthy parish in the West Fjords. 


\subsection{Conclusion}

Over the course of the fourteenth century, a distinctive and self-conscious sense of shared identity developed among the sub-episcopal elite clerics of Iceland. One important element of this shared identity was its emphasis on relationships between individual members of the clergy. In particular, the sub-episcopal elite developed a complex and deeply significant relationship with the bishops in Iceland, both as individuals, and as leaders of the diocese. These relationships were formed and reinforced in a number of ways. Elite priests formed formal ties of friendship and loyalty with the bishops they served, and the priests who formed these ties also acted as the advisors, allies, and emissaries of the bishop they served. Sometimes, the subepiscopal elite clashed with their bishop, impeding his ability to govern in the diocese. At the same time, the bishop held the power to remove the sub-episcopal elite from their benefices, or from their positions as diocesan officers. Thus, although the sub-episcopal elite managed over the course of the fourteenth-century to carve out a position of importance for themselves, they remained subordinate to the bishop, and could not be secure of their positions if they fell foul of their bishop. In all, while these relationships also strengthen the bishops and allowed them to rule effectively in their diocese, they also provided the elite clergy with a strong voice in diocesan politics.

Personal relationships and social networks also played an important role in the ways the sub-episcopal elite thought of and valued elements of non-canonical clerical practice, such as clerical concubinage and clerical violence. Members of the sub-episcopal elite not only engaged in these practices, they used them to futher their own social networks. The children of clerics, or at least sons intended for a clerical career, provided an opportunity to strengthen ties through fosterage and the provision of a clerical education. Violent conflict between clerics also created networks of both alliance and animosity. Particularly when conducted between bishopric and monastery, violent conflict also appears to have been integrated into wider expressions of conflict, such as the withholding of hospitality.

All of these expressions of elite clerical identity, however, have their root in the beneficial culture created in Iceland after the success of the staðamál conflict. The elite clergy were also a beneficed clergy, and it was from the staðir that their 
wealth, power, and position originated. While some members of later generations of elite clergy also had independent sources of wealth, the basis of their power remained the staðir. The granting of benefices was one of the strongest powers that the bishop held over the sub-episcopal elite, as well as the power to take them away. The staðir provided a wide source of income, including ecclesiastical fees, tolls, and tithes, as well as the income from the farm, its dependent properties, and its rights to usufruct. Additionally, the staðir provided the sub-episcopal elite with the status and security of the land-holding classes in Iceland. From this base, the elite clergy were able to develop their positions in ecclesiastical administration, in the social networks of the Icelandic and Norwegian Church, and as powerful Icelandic aristocrats. 


\section{Chapter Five}

\section{Norway and Elite Icelandic Clerical Identity}

Up to now, my discussion of the sub-episcopal elite clergy has been confined to their position within Iceland. I discussed the financial and social importance of the staðir when converted into benefices, the relationship between the sub-episcopal elite and their bishop, as well as clerical reinterpretation and use of Icelandic social structures and cultural practices. But in confining this discussion to Iceland, we are missing a crucial aspect of elite clerical identity: their relationship to, and views of Norway and the Norwegian Church. The fourteenth century has been called 'Norska Öldin', the Norwegian Age, for the increased contact with Norway in this period, both political contact after Iceland's submission to the king of Norway, and economic contact, with the growth of the stockfish trade (see Chapter 1). Clerical contact with Norway had even deeper roots. From its establishment in 1152, part of the mission of the archiepiscopal see of Niðarós had been to integrate and regulate the far-flung churches of Norway and the North Atlantic. ${ }^{1}$ While its success in this undertaking was varied, and its commitment can only be described as intermittent, the influence of this centuries-long history can be felt in the attachment of fourteenth-century Icelandic clerics to their metropolitan. That fourteenth-century Icelandic clerics felt deeply involved with their metropolitan in Niðarós is made very clear by the writing of this period; fourteenth-century bishops' sagas and annals place an unmistakable emphasis on Norway and the Norwegian Church. One of the most notable elements of this writing on the Norwegian Church is the prominent role given to accounts of Icelandic priests' travels to Norway, and their adventures in the Norwegian Church. In bishops' sagas, in particular, the hero's voyage to Norway is often presented as a young man's rite of passage, reminiscent of similar themes in the Íslendingasögur.

In this chapter, I examine the relationship between Norway and elite Icelandic clerical identity with particular emphasis on Icelandic clerical travels to Norway; this analysis is in three parts. In the first place, I examine the evidence for clerical voyages to Norway, particularly from annalistic and documentary sources,

\footnotetext{
${ }^{1}$ Helle, 'The Norwegian Kingdom: Succession, Disputes and Consolidation', p. 376; see
} also Eljas Orrman, 'Church and Society', p. 430. 
and argue that there is evidence to suggest that the elite Icelandic clergy did in fact travel frequently to Norway and were well-integrated into Norwegian clerical networks. Secondly, I examine a motif from the bishops' sagas, namely the bishop's initial voyage to Norway as a young man, with a particular focus on Lárentíus saga. These highly stylised accounts provide an idealised view of Norway and the Norwegian Church, in which Icelandic clerics were singled out for attention by kings and archbishops, and were depicted playing an important role in political events. Finally, I examine accounts of journeys to Norway which do not fit the motif of the young man's initial voyage abroad: journeys made by bishops or their deputies, and the voyage to Norway to be consecrated as bishop. These accounts are more varied and often depicted in a more realistic style; they provide a different view of the journey to Norway, one in which concerns such as finances, accommodation, and the importance of personal networks play a large role. At the same time, they show as clearly as the bishop's initial voyage to Norway how important the voyage to Norway was in the imaginations of elite Icelandic clerics.

Throughout this analysis, I will attempt to draw out the role that Norway and the Norwegian Church played in what it meant to be a member of the elite Icelandic clergy. The sub-episcopal elite used Norway and the Norwegian Church in their writing and thinking on this subject; they wrote frequently and persuasively of their connections with Norwegian clerics: canons, bishops, and archbishops. In Icelandic writing and thought, these might all be the dear friends, mentors, and supporters of Icelandic bishops, priests, and even exceptional young clerics in minor orders. Facility with a foreign country, with travel, and with a different ecclesiastical structure were highlighted as necessary elements of an Icelandic clerical education, as much or more important than facility with local parochial concerns, the maintenance and development of ecclesiastical estates, or episcopal politics. Over the course of this chapter I will attempt to explain why foreign travel, and Norway in particular, played such an important role in the development of the Icelandic clergy. 


\subsection{Iceland and Niðarós: Introduction}

As discussed above, the Icelandic Church was closely connected to its metropolitan in Niðarós. Icelandic bishops turned regularly to Niðarós for the resolution of disputes, for support in their conflicts with the lay aristocracy, and for guidance and assistance in their efforts to promote and enforce novel ecclesiastical institutions. As I have shown in Chapter 3, the appointment of bishops to Skálholt and Hólar depended closely on Norwegian ecclesiastical politics: the bishops of Skálholt often came from backgrounds in or near to the diocese of Bergen, while bishops of both Skálholt and Hólar often came from prominent positions in the Norwegian Church, most commonly having been leaders of one of the more prominent monasteries or friaries in Norway, or cathedral canons at one of the six mainland Norwegian cathedrals (Chapter 3.3.2). Finally, the Norwegian Church, particularly the archbishop of Niðarós, played a significant role in Icelandic ecclesiastical politics, from Bishop Porlákr Pórhallsson's struggles against lay authority to Bishop Árni's staðamál, as scholars have increasingly been highlighting. ${ }^{2}$ A significant aspect of the Norwegian Church's influence in Iceland was its role in promoting and enforcing 'universal' Church practices in Iceland, as can be seen in the archbishop's role in standardising the appointment of Icelandic bishops after the Fourth Lateran Council of 1215 , in bringing the position of officialis to Iceland, and in promoting and enforcing canon law through the promulgation of archiepiscopal statutes. Thus, the archbishopric functioned as a centralising force, one which mediated between the 'universal' Church and the peripherial dioceses of Skálholt and Hólar.

\subsubsection{Relations with the Archbishop: The Growth of Centralised Authority}

The fourteenth-century Church can be characterised by efforts to centralise power in the office of the papacy in Avignon. This period saw the increased use of papal taxes, papal dispensations, and papal provision of benefices for instance, along with many other developments towards centralisation and bureaucratisation. ${ }^{3}$ One major goal of

\footnotetext{
${ }^{2}$ See Chapter 1.4.1.

${ }^{3}$ For a good overview of the Avignon papacy, see especially Patrick Zutshi, 'Chapter 19: The Avignon Papacy', in The New Cambridge Medieval History, VI, ed. by Michael Jones (Cambridge: Cambridge University Press, 2000), pp. 653-67; see also G. Mollat, The Popes
} 
the papacy in this period was to exert control over the remote peripheries and develop a truly international Church; even its location at Avignon helped in this project, being more central and easier to travel to than Rome. Iceland, too, felt the reach of the Avignon papacy, to some extent; in the fourteenth century, Icelanders began to pay papal tithes, and be subject to papal dispensations in exceptional cases (see Chapter 3.1.2). However, direct contact between the papacy and Iceland appears to have been limited, and had few profound effects on the everyday workings of the Icelandic Church. Where the effects of centralisation were really felt was in increased dependency on the metropolitan of Niðarós, which took on the role of a centralised authority increasingly held only by the papacy elsewhere in Europe.

The increase in the archbishop's reach in specifically papal matters can be seen in matters such as the collection of papal tithes and the granting of dispensations for defect of birth, but it can be seen perhaps most clearly in changing attitudes towards canonisation in Iceland. The first saints to be venerated in Iceland were formally approved by the secular Althing (Porlákr in 1198-99 and Jón Ögmundarson in 1200). ${ }^{4}$ By the fourteenth century, approval by the Althing was no longer sufficient. However, it was not the approval of the papacy which fourteenth-century clerics sought for their veneration of native Icelandic saints, but the archbishop of Niðarós. Angrímr Brandsson's Guðmundar saga (Guðmundar saga D) includes an episode in which Bishop Guðmundr, during the first of his two longer stays in Niðarós, approached the archbishop to ask permission to 'sing [mass] for St Porlákr, according to Icelandic custom'. The archbishop refused, saying, 'I do not give permission for this, that you should break our laws here in Norway, whatever you might do, my Lord, in Iceland'. ${ }^{6}$ Guðmundr skilfully managed to venerate the saint without disobeying the archbishop, by performing the service of All Saints, a service which naturally included St Porlákr, as a true saint, but was not in violation of the

at Avignon 1305-1378, trans. by Janet Love (Edinburgh: Nelson and Sons, 1963); Yves Renouard, The Avignon Papacy, trans. by Denis Bethell (London: Faber, 1970); on the relationship between the Papacy and the English Church, see also W.A. Pantin, 'The Fourteenth Century', in The English Church and the Papacy in the Middle Ages, ed. by C.H. Lawrence (Stroud: Sutton, 1999).

${ }^{4}$ Kirsten Wolf, 'Pride and Politics in Iceland: The Sanctity of Bishop Porlákr Pórhallsson', in Sanctity in the North: Saints, Lives, and Cults in Medieval Scandinavia, ed. by Thomas DuBois (Toronto, ON: University of Toronto Press, 2008), pp. 241-70 (p. 247).

5 'at hann sýngi sælum Porláki eptir íslenzkum vana', Guðmundar saga D, p. 94.

6 'pat lofast eigi at pér brjótið lög á oss hér Noregi, hversu sem pér gerit, herra, á Íslandi'. Guðmundar saga D, p. 94. 
archbishop's commands. In this episode, however, we can still see a tension between 'Icelandic custom', and the Church laws in place in Norway. The archbishop's insistence that venerating St Porlákr would go against the law highlights the newly legalistic nature of canonisation. Even in Bishop Guðmundr's request to venerate St Porlákr according to 'Icelandic custom', we can see his acknowledgment that Icelandic custom was both different from Norwegian traditions, and contrary to the laws of the Church. Finally, here we see the archbishop of Niðarós placed as the arbiter of what is legal, and what is permitted in the veneration of local saints. Guðmundr followed his own conscience in the end by venerating St Porlákr through the service of All Saints', but by first asking for permission, and later refusing to directly disobey the archbishop's commands, this bishop (a local saint himself) can be seen to have accepted and legitimised the archbishop's role as the final arbiter of sanctity and of correct legal procedure.

The legalistic nature of concerns about the legitimacy of native Icelandic saints is illustrated even more clearly in a passage from Lárentíus saga, also concerning the sanctity of St Porlákr. In this episode, however, the archbishop's power over Icelandic worship can be seen to have extended also to practice in Iceland. On a visitation in Skálholt in 1307, Lárentius asked his co-visitor, a Dominican friar from Norway, to preach a sermon about St Porlákr for his feast day. The friar replied contemptuously:

'You Icelanders are strange people, because you call saints many people who have grown up here among you, and of whom people in other countries know nothing. It is very bold of you Icelanders to hold these men for saints, whom the archiepiscopal see in Niðarós does not keep in memory. On the contrary, this evening, when you priests are ready to go to evensong, I shall go up in the choir and forbid the bishop and all the priests to sing about this man, Porlákr, until it should be taken into law by our lord the archbishop and all the bishops in the provincia Nidarosiensis ecclesiae [province of the cathedral of Niðarós].

Undarligar menn eru pér Íslendingar, pví at pér kallað pá marga heilaga menn sem hér hafa vaxit upp hjá yðr ok í öđrum löndum vita <menn> engin skyn á, pví er mikil dirfð yðar Íslendinga at pér haldið pennan mann helgan sem erkibyskupsstóllinn í Niðarósi heldr enga minning af. Skal ek heldr í kveld, sem peir klerkarnir ætla at fara til aftansöngs, fara upp á kór ok fyrirbjóða byskupinum ok öllum klerkum at syngja af pessum manni, Porláki fyrr en pat er lögtekit af várum herra erkibyskupinum ok öllum byskupinum í provincia Nidarosiensis ecclesiae. ${ }^{7}$

${ }^{7}$ Lárentíus saga, p. 269. 
This exemplary episode continues by describing the friar's punishment for his disbelief and blasphemy against St Porlákr, and ends with his acknowledgement of Porlákr's saintliness. It is his specific concern here which is interesting to the present discussion, namely his insistence that Icelanders could not worship a saint, 'until it is taken into law by [...] the archbishop and all the bishops in the province of the cathedral of Niðarós'. This suggests an important shift in legal jurisdiction in the clerical imagination; authority over appropriate forms of worship in Iceland in this passage belonged to the archbishop, together with his suffragen bishops. It is revealing that this passage names the archbishop, and not the pope, as the final authority on the matter of Icelandic saints. As early as 1173, Pope Alexander III had declared that the right to make saints was reserved to the papacy, in a letter to an unnamed king of Sweden. ${ }^{8}$ The popes of the early thirteenth century continued in this effort, and by the mid thirteenth century the papal monopoly on the right to canonise saints was well established, as were the formal legal proceedings of canonisation investigations. ${ }^{9}$ In Iceland however, as this passage makes clear, this power was reserved only to the archbishop of Niðarós. ${ }^{10}$ Both passages above demonstrate a respect for the authority of the archbishopric at Niðarós, and a need for native Icelandic saints to be legitimised by a higher ecclesiastical authority. At the same time, the texts make no mention of the papacy, pointing only to the authority of the archbishop of Niðarós, together with his suffragen bishops. Thus, although fourteenth-century sources reveal a certain interest in and awareness of the papacy and papal policies, it seems clear that the most strongly felt centralising

\footnotetext{
${ }^{8}$ Dick Harrison, 'Quod magno nobis fuit horrori...: Horror, Power and Holiness within the Context of Canonization', in Procès de canonisation au moyen âge: Aspects juridiques et religieux, ed. by Gábor Klaniczay (Rome: École Française de Rome, 2004), pp. 39-52. On saints and canonisation practices in the later Middle Ages, see especially André Vauchez, Sainthood in the Later Middle Ages, trans. by Jean Birrell (Cambridge: Cambridge University Press, 1997).

9 E.W. Kemp, Canonization and Authority in the Western Church (Oxford: Oxford University Press, 1948); Gábor Klanziczay 'Proving Sanctity in the Canonization Processes: Saint Elizabeth and Saint Margaret of Hungary' in Procès de canonisation au moyen âge, ed. by Gábor Klaniczay, pp. 117-48 (p. 117).

${ }_{10}$ However, many scholars have suggested that the fourteenth-century veneration of Guðmundr Arason included attempts at papal canonisation of the popularly venerated saint. The evidence for this argument seems flimsy, and ignores the realities of the papacy's fourteenth-century canonisation process, which was both extremely formal and extremely expensive. For another viewpoint, see Joanna Skórzewska, Constructing a Cult, especially p. 26.
} 
power remained that of the archbishop in Niðarós, to whom the Icelandic clergy turned for matters requiring a higher ecclesiastical authority. The archbishop's role as a centralising authority, to whom Icelandic clerics turned for arbitration, communication with the papacy, and as an authority on matters of canonisation and worship may begin to explain Icelandic literary interest in Norway and Niðarós, as well as the percieved importance of Icelandic cleric's facility with the Norwegian Church and Norwegian networks of patronage. As I will argue below, it may also be connected to Icelandic ideologies surrounding the figure of the archbishop, and his relationship with the Icelandic clergy.

\subsection{Icelandic Clergy in Norway}

Having discussed the role that the Norwegian Church, specifically the archbishop of Niðarós, played as a authority, appeals court, and arbiter of Church doctrine in Iceland, I now turn to a discussion of elite Icelandic clerics who travelled to Norway as part of their clerical careers. As I discussed in Chapter 2, one of the most consistently reoccurring topics in the fourteenth-century annals are journeys to Norway, which are recorded with great regularity (Chapter 2.4, see also Chapter 3.3), while the bishops' sagas are even more detailed in their descriptions of journeys to and from Norway. The impression from these narrative sources is one of frequent voyages to and from Norway, and of Icelandic clerics fully at home with and closely integrated into the Norwegian Church (see below, section 5.3 for more detailed discussion of Norway in clerical narratives). With that in mind, presented here is a study of Icelandic clerics abroad from contemporary evidence. While some of the data presented here is drawn from narrative sources, the majority represents fragmentary evidence from Icelandic documentary material, annals, and Norwegian documentary sources. The aim is to present a picture of Icelandic clerics in Norway to compare with the self-conscious accounts found in bishops' sagas and some of the annals. As I will show, although the evidence for journeys to Norway outside of clerical narratives is less extensive than that presented in narrative sources, it is sufficient to suggest that voyages to Norway could have been an important aspect of Icelandic clerical careers. 


\subsubsection{Icelandic and Norwegian Clerics: Problems of Terminology}

Before beginning a discussion of Icelandic clerics in Norway, it is worth noting that Icelandic annals, charters, and even bishops' sagas make no real distinction between Icelandic and Norwegian clerics; the sagas and annals rarely preface the name of an Icelandic or Norwegian cleric with islenskr or austmaðr, as they do for Danish clerics, in particular (who are called danskar klerkar, or útlenskir). ${ }^{11}$ Indeed, not one of the approximately nine Norwegian bishops in Iceland from 1304-1400 is anywhere described as austmaðr or norranr. This is not to say that Icelandic clerics were unaware or uninterested in the distinction between the two nations; on the contrary, they seem to display a certain anxiety about the disrespectful treatment of Icelanders abroad. ${ }^{12}$ However, in accounts of interactions between individual clerics, whether Icelanders in Norway or Norwegians in Iceland, the question of nationality does not seem to be of much importance.

Sean Hughes has recently argued that the Norwegian bishop, Jón Halldórsson, was in fact born in Iceland, but raised in Norway in the Dominican friary in Bergen. ${ }^{13}$ The primary piece of evidence for this is that Jón's mother's name, Friðgerðr, is unknown outside of Iceland; Hughes is able to construct a very convincing argument by retelling the bishop's life in this new light. The result is speculative, but persuasive. Hughes suggests that Jón and his brother Finnr accompanied their parents to Bergen, where they were orphaned. Monasteries frequently took in orphans as oblates, and it seems possible that this was Jón Halldórsson's career path; from his páttur, for example, it is clear that he had been in the Dominican friary from childhood. ${ }^{14}$

As contemporary sources make no attempt to clarify the nationality of the priests and bishops under discussion, Hughes' proposal raises the intriguing possibility that other 'Norwegian' bishops, not to mention lesser clerics, might have been born in Iceland, but made their early careers in Norway. This possibility is

\footnotetext{
${ }^{11}$ See, for instance, Flateyjarannáll, pp. 418, 423; Lögmannsannáll, pp. 282, 285 (útlenskir, not necessarily Danish). But see Lögmannsannáll, p. 289 and Lárentíus saga, p. 365 for two specific cases where Icelandic servants are preferred to Norwegian ones.

${ }^{12}$ This can be seen most clearly in stories of native Icelandic saints being mocked or disbelieved abroad (see above, section 5.1.1).

${ }^{13}$ Hughes, 'Klári saga as an Indigenous Romance', pp. 135-164.

${ }^{14}$ Ibid., p. 138; see also Jóns páttr Halldórssonar, pp. 454-55.
} 
raised again through what is known of the life and career of Eysteinn rauði, the grandson of the Norwegian bishop of Hólar, Auðunn rauði. Eysteinn rauði, the son of a farmer called Porsteinn and Auðunn's daughter Ólöf, was brought to Hólar with his grandfather, educated in the north of Iceland under Lárentius Kalfsson, and later held the Church of St Mary in Trondheim, where Auðunn was buried. Bishop Auðunn arrived in Hólar in 1314, and Eysteinn seems to have accompanied his grandfather at that time. Einarr Hafliðason, the author of Lárentíus saga, writes of himself that he went to be taught by Lárentius when he was ten years old; 'he went from there to Hólar, when Bishop Auðunn came to Iceland and was all the time with his [Auðunn's] grandson at Hólar while he was bishop there'. ${ }^{15}$ This bit of reminiscence suggests parity between the two young men, and that they may have been of similar ages. That Einarr's writing dwelt on the details of the early life of Auðunn's grandson in Lárentíus saga further suggests that they formed a friendship in their youth. As part of the settlement between Lárentius and Bishop Auðunn, negotiated by their mutual friend Egill Eyjólfsson in the fall of 1319, Lárentius was to teach 'the grandson of the Lord Bishop, who was called Eysteinn; he [Eysteinn] went with him and he [Lárentius] taught him'. ${ }^{16}$ Eysteinn's education under Lárentius Kalfsson was part of a settlement between Lárentius and Auðunn, one reminiscent of saga-age fostering agreements (Chapter 4.5.1). Eysteinn's reaction to this arrangement is not described, but if his relationship with his tutor was comparable to that of a foster-son, or even similar to that described as existing between Lárentius and his other pupils, he must have developed a close relationship with his new tutor.

Eysteinn was not Ólöf's only child; she had at least three sons by two husbands. ${ }^{17}$ Nowhere is it said that Ólöf, either of her husbands, or her father Auðunn Porbergsson, were Norwegian by birth or nationality, but Auðunn's career before becoming bishop of Hólar was in Norway, and Ólöf's youngest son, Óláfr Klemetsson, appears as a witness in a handful of charters from the region of Trondheim in the $1340 \mathrm{~s} .{ }^{18}$ There is no evidence to suggest that either of Eysteinn's

\footnotetext{
15 'fór hann paðan til Hóla sem Auðun byskup kom út ok var allan tíma meðr hans dóttursonum á Hólum meðan hann var par byskup', Lárentíus saga, p. 319.

16 'Skyldi bróðir Laurentius kenna dóttursyni herra byskups, er Eysteinn hét; fór hann með bróđur Laurentio ok kenndi hann honum', Lárentíus saga, p. 338.

${ }^{17}$ Lárentíus saga, p. 320.

${ }^{18} \mathrm{RN} \mathrm{V}$, nos 534, 706, 786, 825, 856.
} 
brothers joined him in Iceland. Óláfr, for one, seems not to have entered the church, and it may be that Eysteinn, being intended for a clerical career, was sent to Iceland to be educated and provided for by his successful grandfather. Whatever the reason for sending him to Iceland, Eysteinn's Icelandic education clearly did not damage his chances in the Norwegian church. According to Lárentíus saga, Eysteinn 'later became a prominent person, and had the church of St Mary in Trondheim for a long time and was called Eysteinn rauði'; according to Norwegian documentary sources, he was in Niðarós in $1345 .{ }^{19}$

As the specific examples of Bishop Jón Halldórsson, and Bishop Auðunn and his family suggest, the distinction between 'Icelandic' and 'Norwegian' clerics was not always clearly made in the fourteenth century. Auðunn's grandson Eysteinn was born in Norway, educated in Iceland, and returned to Niðarós to take up a valuable benefice as an adult. His ties formed as a schoolchild were all with prominent members of the Icelandic sub-episcopal elite; these ties did not prevent him from having a prominent career in Norway. Jón Halldórsson, raised from childhood in the Dominican friary in Bergen, nevertheless had a successful career in Iceland, and no ties or markers of Norwegian identity to contradict Hughes' radical suggestion that he was in fact born in Iceland. Both Jón Halldórsson and Auðunn and his family were so closely interconnected with both Norwegian and Icelandic clerical networks that their 'national' identities have been blurred to the point of irrelevance. Moreover, these two examples are not singular; Norwegian bishops arriving in Iceland appear to have been at home almost immediately upon arrival, while Icelandic clerics in Norway do not seem to have been treated as foreigners, as we will see below (see also section 1.2.2 for a similar phenomenon among secular officials in Iceland). As the examples presented above suggest, the distinction between 'Icelandic' and 'Norwegian' clerics may not have been as clear-cut as the study below might suggest.

19 'Varð hann síðan framr maðr ok hafði lengi Máríukirkju í Prándheimi ok var kallaðr Eysteinn rauði', Lárentíus saga, p. 338; see also RN V, no. 786. 


\subsubsection{Icelandic Clerics in Norway: The Evidence}

As described in Lárentíus saga, Lárentius was granted the Church of St Óláfr in Trondheim by Archbishop Jörundr in 1294, some months after Lárentius' arrival at the archiepiscopal palace, where he studied canon law and ran errands for the archbishop ('the archbishop sent him to do his [the archbishop's] bidding in his conflict with the canons'). ${ }^{20}$ Shortly afterwards, Lárentius' friend and tutor, Jón the Fleming, requested to be given the Church of St Mary in Trondheim (the same church later held by Eysteinn rauði), and was refused on the grounds that he could not speak Norse (norrana) and could not communicate with his parishioners. Both of these were major churches within the town of Trondheim, and represented lucrative benefices (as we saw above, the Church of St Mary was granted to Eysteinn rauði, and was the place where his grandfather Auðunn rauði was buried). The patronage of the Church of St Óláfr was a major source of conflict between archbishop and canons at the end of the thirteenth century, further illustrating its importance as a benefice; many parish priests in the cities later became canons. ${ }^{21}$ Both of these examples suggest that non-Norwegian clerics in the service of the archbishop could, and did, hold benefices through the influence of their patron. The argument that Jón the Fleming could not be granted the benefice he desired because he could not communicate with his parishioners suggests that in addition to holding the Church of St Mary as a benefice, Jón would have been expected to also carry out his parochial duties there; the specific objection raised was Jón inability to orally convey to his parishioners their spiritual obligations during Lent. Both of these examples come from a highly fanciful portion of Lárentíus saga, but further evidence can be found from a wide range of source material, including a number of Icelandic annals, Norwegian diplomatic sources, and Icelandic documents, discussed below.

Einarr Hafliðason's Lögmannsannáll provides an example of an Icelandic priest, Einarr's father Hafliði Steinsson, who served as a chaplain (hirðprestur) to

\footnotetext{
20 'erkibyskupinn sendi hann at gjöra sín boð í deilum peira kórsbræðra', Lárentíus saga, p. 241.

${ }^{21}$ Sverre Bagge, 'Nordic Students at Foreign Universities until 1660', Scandinavian Journal of History, 9 (1984), 1-29 (p. 8).
} 
King Eiríkr Magnússon (1280-1299). ${ }^{22}$ Although the dates of his employment are not specified, Hafliði was allegedly present in Bergen when Princess Margaret embarked for Scotland, in the summer of $1290 .^{23}$

There is one further case of an Icelandic priest holding a Norwegian benefice, known from annalistic evidence and Norwegian sources. Flateyjarannáll recorded for 1394 that the priest Jón Porðarson came to Iceland with Bishop Vilchin, 'and he had been abroad for six years, and held Krosskirkja [Korskirken]'. ${ }^{24}$ Jón Porðarson is better known as the initial scribe of Flateyjarbók, and this annal entry is a relatively well-known part of the history of the production of that great manuscript. ${ }^{25}$ The church that he held was probably Korskirken (the Church of the Cross) in Bergen, established in $1181 .^{26}$ In a letter dated 11 March 1390, the bishop of Bergen addressed Jón Porðarson, parish priest of Korskirken. ${ }^{27}$ The letter is an injunction against men living with concubines, who were forbidden to take the Eucharist if they did not desist from their bad living. The bishop instructed Jón to read this letter aloud to his parishioners every Sunday until Easter. As with the case of Jón the Fleming, this letter makes clear that Jón Porðarson not only collected the income from this benefice, but also carried out his parochial duties at his church.

One remarkable feature of this letter is how closely integrated into diocesan affairs Jón Porðarson appears to have been. The letter from the bishop of Bergen gives no indication that there was anything out of the ordinary in Jón Porðarson's tenure as the incumbent of Korskirken, nor does the letter alone give any clue that Jón was not a Norwegian cleric. Unfortunately, this close integration of Icelandic clerics into Norwegian ecclesiastical networks also makes it very difficult to say how common Jón Porðarson's tenure was. It is only with the added information from Flateyjarannáll (itself unusually detailed, probably because of Jón's connection with

\footnotetext{
${ }^{22}$ Eiríkr and his sucessors were in the process of building up the Royal Chancellery at this time, and it may be that hirðprestur in this case means that Hafliði was working as a clerk in the Chancellery; on the Royal Chancellery, see Sverre Bagge, Den kongelige kapellgeistlighet 1150-1319 (Bergen: Universitetsforlaget, 1976).

${ }^{23}$ Lögmannsannáll, pp. 266-67.

${ }^{24}$ kom vt med honum [Bishop Vilchin] Jonn prestr Pordarson $o k$ hafdi vtan verit sex aar $o k$ halldit cross kirkiu'. [Jón Pordarson the priest came to Iceland with him [Bishop Vilchin] and had been abroad for six years and held Korskirken and Guðmundr Porsteinsson the priest; Höskuldr Jónsson the priest], Flateyjarannáll, p. 424.

${ }^{25}$ Rowe, The Development of Flateyjarbók, p. 11.

${ }^{26}$ Ibid., p. 11. On the history of the church, see Øyvind Eide, Korskirken: 1181 - 800 år 1981 (Bergen: Rådet, 1981).

${ }^{27}$ DN III, no. 487.
} 
the manuscript) that we can identify the incumbent of Korskirken with Jón Porðarson, the Icelandic priest and scribe. It is thus difficult to say how commonly Icelandic priests held benefices in Norway. Some Norwegian scholars have emphasised the lack of suitable priests after the Black Death in 1350, and it has been suggested that this necessity may have led the Norwegian Church to accept Icelandic priests. ${ }^{28}$ This explanation, although plausible, treats Icelandic priests as a poor subsititution for Norwegians, a temporary and inadequate solution like the ordination of simpleminded and ignorant men, those born illegitimately, and the very young. ${ }^{29}$ This unflattering interpretation ignores the close cultural and personal ties between Icelandic and Norwegian clerics, and the fluid movement of clerics between these two countries. At the same time, it cannot explain the motivation of the Icelandic clerics; as will be shown below, while working in Norway was seen as an important part of elite clerical identity, it was also transitory. Most Icelandic clerics whose careers are known returned to Iceland after a time; the bishops' sagas also emphasise the return to Iceland of their heroes. Although some Icelandic priests may have received benefices in Norway and remained there, indistinguishable in the extant sources from their Norwegian colleagues, it seems clear that the ideal, at least, was a period of work and study in Norway, followed by a return to Iceland, and hopefully a lucrative benefice there. Such at least appears to have been the career path of those few Icelandic priests whose travels to Norway have been recorded, as I will discuss below.

The Icelandic annals record the travels and return journeys of a large number of priests, unfortunately without mention, in most cases, of the length or purpose of their journeys. In the same entry which records Jón's return, the two priests Guðmundr Porsteinsson and Höskuldr Jónsson are also named, '[...] and also Guðmundr Porsteinsson, priest and Höskuldr Jónsson, priest'. ${ }^{30}$ Unfortunately neither the annal nor any Norwegian source reveals the nature or duration of their voyage to Norway. After their return to Iceland, however, Icelandic documentary material contains evidence which reveal them to be members of the same subepiscopal elite. Guðmundr Porsteinsson held Valpjólfsstaður (a major church) as a

\footnotetext{
${ }^{28}$ Rowe, The Development of Flateyjarbók, p. 11, no. 3; on the Norwegian Church after the Black Death, see Hamre, 'Church and Clergy', pp. 655-58.

${ }^{29}$ Hamre, 'Church and Clergy', p. 657.

30 'ok Gudmundr prestr Porsteinsson Hauskulldr prestr Jonsson', Flateyjarannáll, p. 424.
} 
benefice, and briefly held the position of ráðsmaðr of Skálholt in $1409 .{ }^{31} \mathrm{He}$ was a property-owner, and in 1405 married off his daughter with a generous dowry. ${ }^{32}$ In that same year, Höskuldr Jónsson was granted Breiðabólstaður í Fljótsdal, one of the wealthiest and most important benefices in the diocese of Skálholt (see section 4.1). ${ }^{33}$ Although we do not know what Guðmundr and Höskuldr were doing in Norway, or how long they were there, what is clear is that they were both members of the elite clergy described in Chapter 4, holding major benefices as well as their own property, acting as diocesan officers, and connected by marriage to the secular aristocracy, who also spent some time in Norway.

An entry in Flateyjarannáll records an outbreak of plague in Norway in 1392, and lists almost fifty victims of the disease; sixteen of them are said to be from the diocese of Skálholt, of which ten have the name 'prestr' (priest). ${ }^{34}$ There are no other records of any of the priests in either Icelandic or Norwegian sources, and it is impossible to say how long they had been in Norway, or for what purpose. This entry, however, seems pretty conclusive evidence that more Icelandic priests travelled to Norway than the handful whose careers can be traced.

In addition to these independent voyages, the purpose of which remains unclear, it was common for clerics to accompany bishops on their journeys to Norway, or to serve as the emissaries of their bishop, carrying letters, messages and gifts back and forth. The career of an Icelandic priest named Rúnólfr illustrates many of the transnational services an active cleric could be asked to perform. Rúnólfr served Bishop Jón Halldórsson as a messenger, and in 1337 delivered eight years worth of Peters' Pence from the diocese of Skálholt to Bishop Hákon, who had been appointed collector-general. ${ }^{35}$ He returned to Skálholt with letters from Hákon, but returned to Bergen a few years later, accompanying Bishop Jón, who had been summoned in connection with the payment of papal taxes. ${ }^{36} \mathrm{He}$ was sent in December of 1338 to Niðarós in the place of Bishop Jón, who was too ill to travel; the bishop remained in Bergen, where he died a few months later. ${ }^{37}$ Rúnólfr seems to

\footnotetext{
${ }^{31}$ Lögmannsanáll (Ný Annáll), p. 289.

${ }^{32}$ DI III, pp. 638-39, 705-06.

${ }^{33}$ Flateyjarannáll, p. 424.

${ }^{34}$ Flateyjarannáll, pp. 419-20.

${ }^{35}$ DN VII, no. 143; DI II, pp. 717-18.

${ }^{36}$ DN VII, no. 145; DI II, p. 720. See also Lögmannsannáll, p. 271; the annal places these events in $1335-36$.

${ }^{37}$ DI II, pp. 724-25; see also Jóns páttr Halldórsonar, pp. 454-55.
} 
have remained in Niðarós for several months, and returned to Bergen sometime before 21 April 1339, carrying a gift of whale meat for Bishop Hákon from the cathedral canon Árni vaði Einarsson. ${ }^{38}$ Nothing more is known about Rúnólfr's career until 1345, when Lögmannsannáll writes that he and Einarr Hafliðason travelled to Norway; the annal specifies that they were both travelling 'at the expense of Bishop Jón [Sigurðsson]', which may indicate that they were in his employ in some capacity. ${ }^{39}$ Rúnólfr anima died in Norway during the outbreak of the Black Death in $1349 .^{40}$

The editors of the Diplomatarium Islandicum have speculated that this may be the same as Rúnólfr amma (or anima), who was taught by Lárentíus Kalfsson at his school in the southern monastic community of Pykkvibær in Ver, where he taught for twelve months in 1309. ${ }^{41}$ Lárentíus saga describes Rúnólfr as 'a poor clerk who was patronised by Abbot Porlákr [...]. Síra Hafliði gave him his school-name, that he should be called amma, and thus he was called after that. Later he became prominent, and a good scholar'. ${ }^{42}$ Rúnólfr was thus an impoverished priest without family money to pay for his own education. He was, however, well-connected; as this quote makes clear, he was connected to Bishop Lárentius, Hafliði Steinsson, and Abbot Porlákr Loftsson of Pykkvibær (1314-54), as well as to Einarr Hafliðason (not to mention his various patrons or employers in Norway, described above). At the same time, his gruelling work as a messenger between Iceland and Norway, Bergen and Niðarós may well indicate, like the passage above, that he was not as wealthy or fortunate as many of his contemporaries who also studied with Lárentius Kalfsson.

A final instance of an Icelandic cleric working in Norway also comes from the correspondence between Bishop Jón Halldórsson of Skálholt and Bishop Hákon of Bergen. The relationship between these two men is particularly well-documented, as a remarkable number of documents and letters from Bishop Hákon's episcopate have survived, preserved in the so-called 'Bergen copybook', a collection of 509

\footnotetext{
${ }^{38}$ DN VIII, no. 119. Árni vaði, who would later become archbishop, is also mentioned in Lárentíus saga as having become 'the dearest friend' of Bishop-elect Lárentius, p. 364.

39 'ok voru vm bord badir samt a koste herra Jons byskops', Lögmannsannáll, p. 274.

${ }^{40}$ Gottskálksannáll, p. 354.

${ }^{41}$ DI II, p. 1050; see also Lárentíus saga, p. 309, no. 2.

42 'einum fátækum klerk er Porlákr ábóti veitti, er Runólfr hét. Gaf síra Hafliði honum skólanafn at hann skyldi heita amma, ok svá var hann kallaðr síðan. Varð hann framr síðan ok góðr klerkr', Lárentíus saga, p. 309.
} 
letters from the period $1305-42 .{ }^{43}$ In a letter to Bishop Jón Halldórsson from 1337, Bishop Hákon of Bergen wrote:

Hrafn Porvaldsson, a cleric of yours whom you sent to us a mass-deacon in orders, we return to you ordained as a priest through God's power and our office, which God has allowed us to hold. Now, because he has conducted himself during this time at our residence as a good and wise, diligent man, which is clear in all his doings and which you yourself bore witness to in your letters, we ask you that you allow him to be rewarded for all his meek service. It seems to us in this, that we want him to have, for the sake of our request, power over one benefice or other, giving it to him as seems to be appropriate to you, and as his worth demands.

Ramfn Poralldsson klerk ydarn sem per sendor til vaar mösso diakn aat vigslu sendom ver aftr til ydar vijgdan prest med guðs vallde ok vaaro ambetti pi sem gud hefuer oss leet ouerdom. $\mathrm{Nu}$ af pi at hann hefuer so haft sik $\mathrm{j}$ vaarom garde vm pessar ridir sem æinum godom ok spokum dughande manne ber til $\mathrm{j}$ ollu sinu framferdi ok per berit honom sialfuir vitnisburd $\mathrm{vm} \mathrm{j}$ brefue ydru, pa bidium ver yder at per later hann pes niotanda verda firir alla sina audmiuka pionostu, oss teeda $\mathrm{j}$ bui sem ver villdum hann kraft hafua, saker vaars bönastadar eitt huert beneficium pat honum gefuande sem yder pykkir tilfellileght vera ok hans verdleikr krefuer. ${ }^{44}$

Here again, we see an instance of a presumably Icelandic priest who travelled from the bishopric of Skálholt to Norway, where he worked in the service of Bishop Hákon of Bergen. In this instance again, it seems that the cleric Hrafn went to Norway relatively early in his career, being only ordained as a deacon when he arrived in Bergen. The nature of his service to the bishop of Bergen is not specified, but it may have been similar to the work carried out by Lárentius in his saga, or the errands carried out by Rúnólfr. Although Jón Halldórsson's response to this letter is unknown, the letter alone would suggest that Hrafn's time in Bergen advanced his career by bringing him the patronage of the bishop of Bergen, a person who was in a position to ask favours of the bishop of Skálholt. Again however, Hrafn does not seem to have asked for or been offered a benefice from within the diocese of Bergen; after spending an unspecified amount of time as a junior cleric working in the service of the bishop of Bergen, he chose or was expected to return to Iceland to receive a suitable benefice.

\footnotetext{
${ }^{43}$ Nedkvitne, The Social Consequences of Literacy, pp. 39, 236; Bjarne Berulfsen, 'Bergens kopibok', KLNM, 1, cols 475-76.

${ }^{44}$ DN VII, no. 145; DI II, p. 720.
} 


\subsubsection{Icelandic Clerics in Norway: Conclusions}

Even from the limited evidence outlined above, some general trends can be identified. First is the strong impression that even those Icelandic priests who were most successful in Norway did not remain there permanently. Jón Porðarson held Korskirken in Bergen, but he returned to Iceland after six years in Norway. Like Hrafn Porvaldsson, Lárentius worked for a powerful patron: in his case, the archbishop of Niðarós. More fortunate than Hrafn, he also received a parish within the cathedral city: like Hrafn, however, he gave up his position in Norway in 1307, and spent the rest of his career in Iceland. Other priests remained in Norway for an even shorter period of time, serving as messengers or deputies of their bishop, like Síra Rúnólfr, or accompanying a bishop on his trips to Norway. Some Icelandic priests may have entered the service of the king as clerks, as Hafliði Steinsson did. For many others, all that is recorded are their journeys to and from Norway, and occasionally their deaths. What they were doing in Norway is not clear; they may have been studying, visiting, or serving archbishops, bishops, or kings. Whatever they were doing, it seems that the majority of them intended to return to Iceland after a period abroad.

A second conclusion which can be drawn from this evidence is the concentration of Icelandic priests in the cathedral cities of Trondheim and Bergen. This is hardly surprising, as these two towns were both the largest and oldest cathedral towns and the most accessible by sea. The archbishop of Niðarós and the bishop of Bergen were both in excellent positions to provide for their clients, and maintained relationships with the bishops of Hólar and Skálholt respectively (Chapter 3.3.2).

Finally, although the evidence which I have presented here is fragmentary, it does suggest that a significant number of Icelandic clerics travelled regularly and frequently to Norway as part of their careers. Those who did showed a remarkable level of integration into Norwegian clerical social networks and Norwegian networks of patronage. They were able to find employment, patrons, and in a few instances, benefices with little apparent difficulty. At the same time, this conclusion should not be overstated; it is worth bearing in mind that the evidence for Icelandic clerics in Norway is not extensive. 


\subsection{Icelandic Perceptions of Norway and Niðarós: Themes}

In this section, I will attempt to draw out a few themes relating to Norway, Niðarós, and the Norwegian archbishop found in Icelandic clerical narratives; my aim in this is to suggest some ways in which the Icelandic clerical elite imagined their relationship with the Norwegian Church, with the cathedral city of Niðarós, and with their archbishop. The Icelandic relationship to Norway after Iceland's subjugation to Norway in 1262-64 has been a subject of some debate. While some scholars have seen this as a period of a closer connection between Iceland and Norway, others have emphasised Icelandic resentment towards the Norwegian bishops, and Norwegian influence. ${ }^{45}$ These studies however have tended to think about this relationship in the abstract, along institutional and national lines. I have already shown that this relationship can also be seen through the social networks of individuals who make up these institutions. In this section, I will discuss the way these networks were conceptualised by the Icelandic clerics who navigated them. I will show that these networks were conceptualised at least partially through the use of very traditional stylistic features: themes, language, and structures shared with traditional forms of Icelandic writing such as the Íslendingasögur and pattir. Adapted to a clerical milieu, these features serve to emphasise continuity with the past, particularly in discussions of leadership and personal character. Moreover, by retaining the structure of traditional literary genres, these narratives allow for new values to be effectively highlighted: these new values were clerical and learned, and reflected the learned culture of the clerical elite.

\subsubsection{The Initial Voyage to Norway}

Norway and the experiences of Icelanders in Norway are important themes in much of secular Icelandic literature, particularly the Íslendingasögur and pattir. ${ }^{46}$ Norway allowed Icelandic writers to explore themes such as Icelandic identity, authority, and

\footnotetext{
${ }^{45}$ See for instance Jón Viðar Sigurðsson, 'Chapter 3: The Norse Community’; and Magnús Stefánsson, 'Frá goðakirkju til biskupskirkju', pp. 250-52. See also below, Chapter 6.2.1.

${ }^{46}$ John Lindow, 'Páttr', in Medieval Scandinavia: An Encyclopedia, ed. by Philip Pulsiano et al., pp. 661-62. See also Margaret Clunies Ross, 'From Iceland to Norway: Essential Rites of Passage for an Early Icelandic Skald', Álvismál, 9 (1999), 55-72.
} 
the measure of individual success. An individual's success in Norway was used to express his status as a hero, and the notice of a king indicated the hero's status as a person worth noticing. While Icelandic authors demonstrated a certain ambivalence towards Norway, and particularly towards the power of king and court, they also demonstrated a strong interest in, and appreciation of Norway, and the Norwegian king and his court.

Voyages to Norway, in particular for young, ambitious clerics, were ubiquitous in Icelandic clerical literature as well; so much so that Ásdís Egilsdóttir has identified the titular hero's journey to Norway to be consecrated as bishop as one of the conventions of the genre of bishops' saga. ${ }^{47}$ As in many secular narratives, the hero's initial journey to Norway often occurred early in the hero's career. Lárentius, for example, travelled to Norway as a young cleric (at about age 26 or 27), after being disappointed by the patronage of Bishop Jörundr Porsteinsson. Jón Ögmundarson's saga (Jóns saga helga) includes a detailed section describing his early journeys in Denmark and Norway as a subdeacon, before becoming bishop of Hólar. ${ }^{48}$ Árni Porláksson's initial visit to Norway, at which he met the king of Norway who prophesised that he would become a great bishop, took place when he was a deacon in the service of Bishop Brandr of Hólar (1263-64); typically of Árna saga, the account is terse and, apart from the king's prophecy, unremarkable. ${ }^{49}$ Only Guðmundar saga D sets the hero's main travels to Norway during his time as bishop, although this may reflect the reality of Bishop Guðmundr's troubled episcopate, most of which was spent in exile from his diocese. As I have shown above, in describing the voyage to Norway as part of the early career or late education of their heroes, the bishops' sagas may well have been reflecting the reality of elite Icelandic clergy. At the same time however, this convention, reflecting as it does a similar convention in secular Icelandic narratives, serves to suggest that a trip to Norway was a necessary part of the education of a young cleric aspiring to success in Iceland. What they learned abroad will be discussed below.

Much like in the Íslendingasögur, the Norwegian sections of most clerical narratives tend to provide some of the most fanciful or at least colourful portions of

\footnotetext{
${ }^{47}$ Ásdís Egilsdóttir, 'Biskupasögur og helgar ævisögur', p. xx.

48 Jóns saga ins helga, in Biskupa sögur I: Síðari hluti, pp. 184-90; see also Gísls páttr Illugasonar, pp. 319-35 and Samundar páttr, pp. 339-43.

${ }^{49}$ Árna saga, p. 8.
} 
the narrative. In Jóns saga helga, the Norwegian section of the saga includes the story of Gísl Illugason, in which an Icelander, Gísl, was arrested for killing a Norwegian member of the hirð (court). ${ }^{50}$ Placed in irons and in a dungeon, he was rescued by Teitr the son of the first bishop of Iceland and a band of Icelanders who stormed the dungeons. Sentenced to death, he was rescued from the gallows, this time by Jón, who threw a cloak over his body; every part of his body covered by the cloak remained alive even after hanging on the gallows for three days, but his feet, which had not been covered by the cloak, were stiff as if they were dead. After completing his rescue of Gísl by curing his feet, and obtaining a pardon for him from the Norwegian king, Jón's Norwegian voyage ended with an account of his madcap adventures with Sæmundr fróði, among which they tricked Sæmundr's master, an astrologer with great power, into releasing his apprentice. ${ }^{51}$ This stands in contrast to the remainder of the saga, particularly its description of Jón's customs as bishop of Hólar. At Hólar, Bishop Jón had the small church which stood there torn down, and replaced with a larger building; he established a school, and reformed the morals of the people in his diocese; much more prosaic activities. Even Jón's later travels, including his voyage to Rome to be granted dispensation for his previous marriage, are more prosaic and significantly less eventful than his early adventures. On his trip to Rome, for instance, the bishop-elect met with the pope, apologised for his previously sinful ways, produced appropriate documentation, was granted dispensation, and hurried home. None of this was quite so adventurous as his previous defiance of the king of Norway, and resuscitation of a hanged Icelander. ${ }^{52}$ It is only in the initial voyage abroad that Jón Ögmudarson, like the heroes of most other bishops' sagas, had truly wonderful adventures.

Moreover, in the bishops' sagas, as in the Íslendingasögur, the Norwegian voyage of the hero allowed for Icelandic heroes to be slotted into major historical

\footnotetext{
${ }^{50}$ This has been edited as a separate páttur in the most recent edition of Jóns saga helga, in Biskupa sögur I: Síðari hluti, pp. 319-35; the páttur is included in the L-version of Jóns saga helga, which some scholars have attributed to Bergr Sokkason, others more conservatively to the 'North Icelandic Benedictine School' (see Chapter 2.2). On the Lversion of Jóns saga helga, see Peter Foote, 'Formáli: Jóns saga helga', in Biskupa sögur I: Fyrri hluti, pp. ccxx-ccxxxiii, and on Gísls páttr, see Foote, 'Formáli', pp. cclviii-cclxvii.

${ }^{51}$ This too has been edited as a separate páttur in Biskupa sögur I: Síðari hluti, pp. 339-43, but can be found in the L-version of Jóns saga helga, the fourteenth-century version of the saga. On Samundar páttr and its relation to the variants of Jóns saga, see Foote, 'Formáli', pp. cclvii-cclxxi.

52 Jóns saga helga, pp. 198-99; on Jón’s customs as bishop of Hólar see especially pp. 20206.
} 
events abroad. In an encomium to his father, Hafliði, in an entry recording his death in 1319, Einarr included a lengthy anecdote about Hafliði's connection with Princess Margaret, the daughter of King Eiríkr of Norway and his wife Margaret of Scotland, better known as the 'Maid of Norway'. Princess Margaret became embroiled in Scottish dynastic politics upon the death of her grandfather, King Alexander III of Scotland in 1286, making the four-year-old princess a potential heir to the Scottish crown. ${ }^{53}$ Four years later, in the autumn of 1390, Margaret was sent to Scotland to be raised there. She died en route, but years later a woman arrived in Bergen from Lübeck, claiming to be Princess Margaret. She was convicted as an imposter, and executed together with her husband in 1301. The story told in Lögmannsannáll was that Hafliði Steinsson was present for the moment when the seven-year-old Princess Margaret was taken on board the ship for Scotland. It is described as follows:

It so happened when Margaret, the daughter of King Eiríkr was made ready in Bergen, and she was to travel to Scotland, as she herself attested later, before she was burned in Norðnes, that 'when I was being born out of that same port - that was by the Apostle's Church - there was a certain Icelandic priest called Hafliði, who was with my father, King Eiríkr. And when the clerics had exhausted their song, that Síra Hafliði began singing veni creator spiritus and they sung out that hymn as I was born onto the ship.'

Síra Hafliði confirmed the same thing when he was told that this same Margaret had been burned at Norðnes.

bar pat pa till er Margrett dottir Eiriks kongs var buin j Biorgwin $o k$ hana skillde flytia till till (sic) Skotlands. sem hun vattade sialf sidan adr en hun var brend j Nordnese. at pa $e r$ ek var petta sama port ofuan flutt. var pat pa hia postola kirkiu. var Jslenzskr prestr er Haflide het medr fedr minum Eirike konge. ok pa er klerka praut songinn. hof hann Síra Haflide vpp veni creator spiritus ok pann ymna songu peir vt sua sem ek var a skip borin. Petta ed sama sannade Síra Haflide. pa er honum var sagdt at su sama Margret hafde brend verin (sic) J Nordnese. ${ }^{54}$

The moment described here - Princess Margaret being prepared to travel to Scotland, and sailing out - is a pivotal moment in the short life of the young

\footnotetext{
${ }^{53}$ Princess Margaret is best known in the context of Scottish dynastic politics, as her death set off the disputed succession which would lead to the Scottish Wars of Independence. The Scottish Historical Review dedicated its October 1990 volume to the anniversary of the death of the Maid of Norway; among the articles see especially Knut Helle, 'Norwegian Foreign Policy and the Maid of Norway', Scottish Historical Review, 69 (1990), 142-56; and G.W.S. Barrow, 'A Kingdom in Crisis: Scotland and the Maid of Norway', Scottish Historical Review, 69 (1990), 120-41.

${ }^{54}$ Lögmannsannáll, pp. 266-67.
} 
princess, as well as being a vivid and memorable scene. What is remarkable in the telling of it is the way in which this story rather unbelievably centres the Icelandic priest, Hafliði Steinsson. The notion that a seven-year-old princess, leaving her family and home for an uncertain future, would remember (let alone know) that 'a certain Icelandic cleric named Hafliði', had sung hymns as she was carried onto the ship is hard to believe. However, the claim puts Hafliði in the centre of the action of this crucial moment in both Norwegian and Scottish dynastic history. By this account, Hafliði was an active participant in this event, and in fact saved the day: when the other clerics stopped singing, it was his hymn that accompanied the princess out of the harbour. However unbelievably, this story included Hafliði not just as a witness to a major political event, but as a heroic participant in it (by a clerical standard of heroism). In this, it reminds the reader of a similar convention in saga writing, in which Icelandic characters find themselves playing a leading role in historic events; one is reminded, for instance, of Egill Skallagrímsson and his brother Porólfr all but singlehandedly winning the Battle of Brunanburgh for King Athelstan in Egils saga. Thus, in clerical narratives of the voyage to Norway, events in Norway were both more fanciful than events from the same narrative taking place in Iceland, and often featured the Icelandic cleric in a heroic light, always at the centre of any adventures. In some cases, the Icelandic clerical hero was written into larger political events, even, as we have seen above, made into an active participant with a crucial role to play.

These young-cleric-abroad episodes are colourful as well as highly formulaic, and there are many aspects of them which would bear closer inspection, particularly across the different sagas and other narratives. I want to focus here on an aspect of particular importance to my study in the previous chapter of clerical social networks and relationships, both lateral (between equals) and vertical (patron-client, or similar), namely the initial meetings between the young clerics and their patrons in Norway: kings and archbishops. One of the defining features of the Icelander in Norway motif in secular literature is the tension between portraying approval by the king or court as a validation of the foreign Icelander's exceptional talents on the one hand, and a strong suspicion of kings and courts on the other. ${ }^{55}$ Moreover, one common theme is a stubborn Icelandic independence which often manifests itself

${ }^{55}$ Margaret Clunies Ross, 'From Iceland to Norway', pp. 55-56; see also Marvin Taylor, 'On Gizzur Porvaldsson's Speaking Style', Saga-Book, 24 (1997), 311-28. 
through refusing the generous offer of service to a king, in favour of returning to Iceland, or some other future.

Lárentius' arrival in Norway illustrates well how these themes, adapted to a clerical context, remained a feature of the bishops' sagas. Arriving in Bergen, Lárentius was asked to compose and write out a letter in Latin on behalf of his patron, which was shown to King Eiríkr. The king was so impressed with the letter that he had Lárentius invited to his feast, and later invited the young clerk to join his service. Lárentius' response is typical of the young Icelander abroad: 'Síra Lárentius thanked the king for his offer, but said that he had promised himself to go on a pilgrimage to St Óláfr's church in Niðarós' ${ }^{56}$ King Eiríkr then invited Lárentíus to stay the winter, which he accepted. Like an ambitious Icelandic skald in an earlier period, or an athletic young warrior, Lárentius was noticed by the king of Norway for his exceptional skill. ${ }^{57}$ Unlike these secular heroes, however, Lárentius' skills were those of a cleric (or clerk): Latin composition, and letter-writing. He was an Icelandic hero in Norway, adapted for the clerical elite to whom his saga was intended. His initial meeting with the king of Norway is typical of Icelandic literature: his value was noticed by the king of Norway, and his worth as a hero is heightened by the king's offer to take the young cleric into his service. His refusal, however, only serves to heighten the sense of his worth even further; it showed that he could hold his own and refuse an offer from the king of Norway, however flattering.

If Icelandic clerics abroad occasionally retained a critical distance towards Norwegian kings and court, at least in conscious self-portraits, the same cannot be said for attitudes towards the Norwegian archbishop, and other members of the Norwegian ecclesiastical court. The archbishops were consistently depicted as good, wise leaders, and the Icelandic clerics travelling to Norway as eager to join their service, and learn from them. This eagerness can be seen even in the language used in less detailed descriptions of encounters between Icelandic clerics and the Norwegian archbishop. The fourteenth-century redaction of Porláks saga stated for instance that, 'Lord Bishop-elect Porlákr went to meet Archbishop Eysteinn as soon

\footnotetext{
56 'síra Lafranz pakkaði konunginum sitt boð, en sagðiz hafa lofat sinni pílagrímsferð til sancte Óláfs í Niðarós', Lárentíus saga, p. 237.

${ }^{57}$ On Icelandic skalds in Norway, see for instance Margaret Clunies Ross, 'From Iceland to Norway', especially pp. 58-63.
} 
as he stepped off the ship, and the archbishop received him exceedingly well' ${ }^{58}$ In a later episode in Lárentíus saga, the author specified that upon arrival in Norway, 'Síra Egill [Eyjólfsson, later bishop of Hólar] went as quickly as possible to meet the archbishop' 59 The eagerness of a newly-arrived Icelandic cleric to meet the archbishop can be seen in their haste to go to him immediately after arrival.

Returning to Lárentíus saga, after Lárentius' encounter with the king in Bergen, he travelled to Niðarós to meet Archbishop Jörundr. The saga describes the archbishop in the most glowing terms: 'archbishop Jörundr was a powerful lord, a good scholar, steadfast in friendship and very generous with his people, and the most handsome (scemilegastr) of men to look upon'. ${ }^{60}$ As in his meeting with the king, Lárentius showed the archbishop his talents for composition and writing, this time showing the archbishop some verses he had composed in honour of Hallbera the abbess of Reynistaður. Like the king, the archbishop was impressed with Lárentius, and asked him to join his service. Unlike the king, who had nothing but admiration for Lárentius' composition, the archbishop was also in a position to offer criticism to the young cleric. He criticised Lárentius' choice of literary pursuit, telling him to 'give up verse-making from now on' [...] 'and study (studera) instead the laws of the Church, for don't you know quod versificatura nihil est nisi falsa figura [that versemaking is nothing but false figures]?' ${ }^{61}$ He assigned Lárentius a tutor in canon law, and Lárentius spent the next few years in Jörundr's service both studying canon law and serving the archbishop in his struggle with the cathedral canons. Thus, the archbishop can be seen as an authority and a teacher; he saw the value of the young cleric Lárentius, but was also in a position to critique and guide him. Service to such a person was thus a source of both pride and personal growth for the young Lárentius, particularly in the areas of legal training and moral development. Such a positive depiction of the archbishop as a good lord and a wise teacher, willing and interested in mentoring young Icelandic clerics, is typical of fourteenth-century

\footnotetext{
58 'Herra Porlákr electus sótti fund Eysteins erkibyskups pegar hann sté af skipi, ok tók erkibyskup við honum forkunnar vel', Porláks saga B, in Biskupa sögur II, p. 156. This detail is not found in the oldest redaction of the saga, Porláks saga A, in Biskupa sögur, II, p. 52 .

${ }^{59}$ Lárentíus saga, p. 411; the same is said of Arngrímr Brandsson, the messenger of the opposing viewpoint, p. 412 (see below, section 5.3.3).

60 'Jörundr erikbyskup var mikill höfðingi, klerkr góðr, vinfastr ok stórgjöfull við sína menn, manna sæmilegastr at sjá til hans', Lárentíus saga, p. 238.

61 'legg af heðan af versagjörð [...] ok studera heldr í kirkjunnar lögum, eða veiztu ei quod versificatura nihil est nisi falsa figura?', Lárentíus saga, p. 240.
} 
clerical narratives. On the very rare occasions that Norwegian archbishops acted against Icelandic heroes in these narratives, this negative action was framed as a mistake, or a temporary aberrance from normal behaviour. This is the case, for instance, in Arngrímr Brandsson's Guðmundar saga D, in which Bishop Guðmundr, a saint of good behaviour (according to the saga), was on two separate occasions reproved by the archbishop of Niðarós. In Arngrímr's account, the archbishop was angry with the saint, and acted in this way only because Guðmundr's deeds had been misrepresented by bad people. Arngrímr wrote explicity that, 'most of his [Guðmundr's] deeds were misrepresented and turned to the left hand: almsgiving to wastefulness, blessings to arrogance'. ${ }^{62}$ In this instance, a good and otherwise discerning archbishop was temporarily misled. ${ }^{63}$ In virtually all other accounts of Norwegian archbishops, they figure like Archbishop Jörundr in Lárentíus saga as good clerics, powerful leaders, and wise men; in their dealings with young Icelandic clerics they act as teachers, mentors, and good judges of character.

\subsubsection{Two Icelandic Bishops in Norway: Finances and Other Concerns}

As I have shown, the accounts of the initial trip abroad of a young cleric often took a specific form in clerical narratives. They often featured the young priest having fantastic adventures, braving dangers, meeting interesting people, and proving his worth. They sometimes placed him within the context of broader political events, usually with an active role, and usually served to highlight his excellence, whether through tests, or the approval of kings and archbishops. But many clerics travelled more than once to Norway and elsewhere abroad, particularly in the bishop's sagas. As I suggested above in the specific example of Jóns saga helga, subsequent journeys abroad or to Norway were generally described in a much more realistic style. Accounts of later journeys tended to be much less overtly formulaic than the young-cleric-abroad episodes, and more varied in their accounts. The problems encountered are more prosaic and the Icelandic clerical heroes more life-sized. Some of the themes explored, however, remain constant: the positive portrayals of

\footnotetext{
62 'flestar hans gjörðir vóru afpýddar ok hneigðar til vinstri handar, ölmusur hans til auðnar, vígslur til ofdirfðar [...]', Guðmundar saga D, p. 93.

${ }^{63}$ Archbishop Pórir is earlier described as 'ríkr maðr, vitr ok vinsæll' [a rich man, wise and popular, Guðmundar saga D, p. 88.
} 
archbishops, the importance of Norwegian clerical networks, and a sense of Norway, particularly the cathedral cities of Bergen and Niðarós, as different from Iceland, but accessible.

Many of these themes can be seen in the account in Lárentíus saga of Lárentius' journey to Norway to be consecrated as bishop of Hólar (c. 1324). When Lárentius travelled to Norway to be consecrated as bishop, he was shipwrecked and the ship lost all its cargo, which mostly consisted of vaðmál (woolen cloth) and skreið (dried fish). ${ }^{64}$ When he told this to Archbishop Eilífr, and explained that he would be unable to pay his way or that of his retainers, the archbishop invited Lárentius and all his followers to stay at his expense. 'Lárentius was invited to eat at the archbishop's table, and his servants were sent to stay in the archiepiscopal palace'. ${ }^{65}$ Near the end of his visit, Lárentius, having recovered much of the property lost in the shipwreck, repaid the archbishop for having kept him and his followers. ${ }^{66}$ The bishop thus left Iceland prepared to pay his own way and that of his retainers for his consecration, but was in need of assistance from the archbishop due to accident. It is worth noting that at his last meeting with Lárentius, Eilífr (in his capacity as officialis of Niðarós) had had Lárentius thrown in a dungeon, humiliated, and sent to Iceland in chains because of his support for Archbishop Jörundr over the cathedral canons. ${ }^{67}$ At this meeting however, Eilífr was portrayed as kind and generous, supporting Lárentius in his financial misfortune; later in the visit, Lárentius brought a number of difficult court cases to Eiliffr for decisions, and the archbishop's wisdom and good judgment are highlighted through his decisions and his advice. ${ }^{68}$ Thus, a positive portrayal of the archbishop of Niðarós can be seen in Lárentíus saga even at the expense of continuity of character. At the same time, in this episode, events are more prosaic than in Lárentius' earlier journey to Norway: difficulties encountered consisted of recovering lost property, and supporting the bishop's retinue without adequate provisions.

A similar set of concerns can be seen in accounts of travel to Norway in Árna saga. This saga is much more political in focus, and includes almost nothing of

\footnotetext{
${ }^{64}$ Lárentíus saga, p. 362; this reflects what is known of Icelandic exports at this time, see for instance Björn Porsteinsson and Guðrún Ása Grímsdóttir, 'Norska Öldin', pp. 131-34.

${ }^{65}$ Lárentíus saga, p. 364.

66 'Umbunaði herra Laurentius byskup erkibyskupinum fyrir kost sinn ok sinna manna', Lárentíus saga, p 371.

${ }^{67}$ Lárentíus saga, pp. 296-305 (see also pp. 247-49 for the beginning of the conflict).

${ }^{68}$ Lárentíus saga, pp. 365, 367-70.
} 
Bishop Árni's young adulthood and early career (see Chapter 2.2.1). There is no account of a young Árni Porláksson having fantastic adventures abroad, although there is an incident in which the young Árni Porláksson is recognised as a future bishop by the king. ${ }^{69}$ It does, however, feature a number of journeys to Norway on the part of the bishop. Most of Bishop Árni's journeys were motivated by the need to gain support for his efforts in the staðamál dispute; the saga trails off in the middle of an account of the bishop in the king's retinue, attempting to be reconciled with the king after a conflict. Additionally, Árni's episcopate appears to have been characterised by a lack of funds. In 1274, for instance, when asked to participate in the Council of Lyons, Bishop Árni delegated his seat to his friend the canon of Niðarós cathedral Sighvatr landi. ${ }^{70}$ Árni's journeys to Norway were similarly characterised by political dealings and financial concerns. On one of Bishop Árni's visits to Norway, the bishop stayed the winter in Niðarós and took lodging in the St Mary's hospice (Máríuspítali), together with his chaplain and two other named priests. ${ }^{71}$ Later on the same trip, when Bishop Árni had gone to visit the king, he spent some time living 'at the king's expense and he had a room for sleeping in the king's palace'. ${ }^{72}$ This might be seen as politically important rather than merely financially advantageous. After all, the purpose of this voyage was to reconcile with the Norwegian king and gain his support for the bishop's reforms, and an invitation into his palace was a good sign of support. However, the saga goes on to describe the king's departure from Niðarós on 30 November 1289, to travel south to Bergen. At that time Bishop Árni was invited by Archbishop Jörundr to stay 'at his expense' (á sinn kost), and he stayed with the archbishop for the winter and into the summer. The saga specifies that 'money was given to him for that'; although this reference to money is obscure, the emphasis on money and the cost of living away from home is clearly emphasised. ${ }^{73}$ Both for Bishop Árni and Bishop Lárentius, money was a concern when travelling to Norway. Lárentius lost his goods and with them his

\footnotetext{
${ }^{69}$ Árna saga, p. 8.

${ }^{70}$ Ibid., pp. 330-32; Sighvatr also acquired a privilegium for Bishop Árni to discharge thirty cases over which he normally would have no jurisdiction, p. 330. Sighvatr landi was one of the three most powerful canons who opposed Archbishop Jörundr at the turn of the century; on the conflict see Helle, Norege Blir en Stat, pp. 180, 191-92; see also Lárentíus saga, pp. 247-49.

${ }^{71}$ Árna saga, p. 188.

72 'var Árni byskup á konungs kosti ok hafði stofu til svefns í konungsgarði', Árna saga, p. 200.

${ }^{73}$ til pess er honum kómu peningar', Árna saga, p. 204.
} 
ability to pay for himself and his retainers, and the generous assistance of Archbishop Eilífr allowed him to maintain himself while waiting for his cargo to be recovered, while Bishop Árni, perpetually short on funds, enjoyed the hospitality of the king and the archbishop, while also benefiting on other occasions from his friendship with the wealthy and powerful cathedral canon Sighvatr landi.

\subsubsection{Egill Eyjólfsson and Arngrímr Brandsson's Journey to Norway}

An extended account of an Icelandic priest's journey to Norway can be found in the second half of Lárentius saga. In about 1327, Bishop Lárentius sent his follower Egill Eyjólfsson to the archiepiscopal palace to plead the bishop's case regarding his dispute with the monks of Möðruvellir. ${ }^{74}$ At that time, Egill held Grenjaðastaðir, the wealthiest benefice in the diocese of Hólar. Lárentius' opponent, Bishop Jón Halldórsson of Skálholt, also sent a messenger, Arngrímr Brandsson, at the time a secular cleric who held Oddi, the wealthiest benefice in the south (and, indeed, in all of Iceland). ${ }^{75}$ The episode thus allows us to see how the two wealthiest clerics in Iceland, after the bishops, could expect to be treated by the archbishop. According to the saga, both Egill and Arngrímr went quickly to meet the archbishop and they were each well-received. Egill was invited 'to be in his [the archbishop's] palace at his [the archbishop's] expense for the winter, with one servant [...] and he sat at the ráðsmaðr's table for the winter enjoying the best of favour'. ${ }^{76}$ The same is said of Arngrímr. The ráðsmaðr assigned the two messengers a single room (loft, possibly implying a room on an upper floor) to sleep in. ${ }^{77}$ The final detail may have been invented to emphasise the equality and goodwill between them; this interpretation is more strongly suggested by the B-version of Lárentíus saga, which states that the two messengers 'ate from one dish and slept in one room; it was so dear between them as if they were brothers, born of the same parents'. ${ }^{78}$ In addition to

\footnotetext{
${ }_{75}^{74}$ Lárentíus saga, pp. 411-14.

${ }^{75}$ On the identity of Arngrímr Brandsson, see Jón Helgason, 'Introduction', in Biskupa sogur, p. 21; see also above, Chapter 2.2.2.

76 'at vera á hans garði ok kosti um vetrinn með einum sveini [...] ok sat á ráðsmannsstóll um vetrinn í bezta yfirlæti', Lárentíus saga, p. 411.

${ }_{78}^{77}$ Lárentíus saga, p. 413.

78 'vóru um einn disk allir um vetrinn ok sváfu í einu lofti, var svá kært með peim sem peir væri sambornir bræðr', Lárentíus saga, p. 413; on the differences between the A and B
} 
demonstrating their closeness, this description of their arrival shows an interesting combination of ostentation and modesty. These two elite priests clearly travelled with their own servants. The saga is clear, however, that they could keep only one at the archbishop's expense. While they were received by the archbishop, they were quickly handed off to his ráðsmaðr, who in the A-version of the saga is explicitly the person responsible for assigning the two priests to rooms. Moreover, they sat in the rádsmannsstóll (the place of the rádsmenn), not together with the archbishop as Icelandic bishops did. ${ }^{79}$ The two priests enjoyed the symbolic prestige of sitting in a place of some honour, of being well-received and of being invited to stay in the archiepiscopal palace, but they also seem to have appreciated the practical assistance of being assigned lodging, and not having to pay for bed and board.

The stay in Norway continued, 'unequally' (pat var misskipt) for the two messengers. Síra Egill went daily to the archbishop, pleading his case, while Síra Arngrimr 'never pressed his case before the archbishop regarding the Möðruvallamál'. ${ }^{80}$ The inequality between them is further expressed by their chosen activities. Síra Arngrímr chose to go every day to an organist to be taught to play the organ, while Síra Egill 'was also in studio (studying) with the archbishop'; moreover he showed himself to be, 'the best scholar (hinn bezta klerkr) and jurist (jurista)' ${ }^{81}$ In this episode again, legal ability and study can be seen as the marker of worth. An additional level of meaning in this episode is that Egill Eyjólfsson, who would follow Lárentius as bishop of Hólar, was increasingly portrayed in the second half of Lárentíus saga with words and actions that parallel Lárentius himself; thus in this episode Egill imitates Lárentius by going to Norway to learn canon law from the archbishop. ${ }^{82}$ The echo of Lárentius' studies in this secondary episode seems a little forced. It is not entirely clear, for instance, what was wrong with Arngrímr learning to play the organ, which he imported to Iceland from this trip (according to

versions of Lárentíus saga, see Guðrún Ása Grímsdóttir, 'Formáli', in Biskupa sögur, III, pp. xciii-c.

${ }^{79}$ Lárentius for instance, sat at the ráðsmannsstóll while in the service of Archbishop Jörundr, but at the archbishop's own table on his visit for consecration, Lárentíus saga, pp. $241,364$.

80 'aldri flutti hann fyrir erkibyskupi um Möðruvallamál', Lárentíus saga, p. 414.

${ }^{81}$ Lárentíus saga, p. 413.

${ }^{82}$ For a clear example of this parallelism, see Egill's speech on being asked to travel to Norway by the bishop, Lárentius saga, p. 410; the speech is a direct parallel of Lárentius' own response to a similar request, p. 248. 
Flatejarannáll). ${ }^{83}$ Moreover, the image of Egill learning canon law from the archbishop is only briefly invoked, possibly because as the middle-aged incumbent of Grenjaðastaðir and able deputy to Bishop Lárentius the image of him learning eagerly from an archiepiscopal mentor fits less exactly than the young Lárentius. The awkward nature of the episode, however, serves to highlight even more clearly the author Einarr's interest in promoting legal knowledge, the study of canon law, and a distinctive kind of close, personal dependency on the archbishop of Niðarós as ideals for the clerical elite to aspire to.

\subsubsection{Iceland Perceptions of Norway and Niðarós: Conclusions}

I have illustrated the emergence of a few recurring themes through a study of different clerical narrative accounts of an Icelandic priest's journey to Norway. The first is the importance of the figure of the archbishop, and the personal relationship forged between him and the Icelandic clergy who travelled to Norway. In this, Icelandic depictions of the archbishop resemble Icelandic perceptions of Norwegian royalty as described by Elizabeth Ashman Rowe. Rowe illustrated how the Icelandic aristocracy continued to imagine a personal relationship between themselves and the king of Norway even as Scandinavian dynastic politics moved further and further away from this model, and from Iceland. $^{84}$ Rowe's 'ideology of personal relationships' can be seen also in Icelandic cleric's view of their relationship with their archbishop. ${ }^{85}$ Clerical narratives emphasised the personal relationship which an intelligent and ambitious Icelander could form with the archbishop of Niðarós. The ideology of personal relationships in clerical narrative continued to be described in the language and format of older Icelandic literature. Through the use of traditional stylistic features, such as the ambitious young Icelander succeeding in Norway and defying Norwegian kings, a rapidly changing world could be reshaped to fit a traditional understanding of power and society.

At the same time, this deliberate use of traditional structures allowed clerical writers to showcase the emerging values of the new clerical elite. Icelander's voyages to Norway featured many of the most prominent features of learned clerical

\footnotetext{
${ }^{83}$ Flatejarannáll, p. 397.

${ }^{84}$ Rowe, The Development of Flateyjarbók, especially p. 26.

${ }^{85}$ Ibid, p. 26.
} 
identity: knowledge and use of canon law, liturgy, writing, composition and Latinity. They also illustrate the gradual but unmistakable process by which ecclesiastical law and authority began to supersede the secular, at least in the minds of the clergy. This can be seen for instance in the contrasting depictions of Lárentius' first meeting with the king of Norway, and with the archbishop in Lárentíus saga.

Finally, the two accounts of Icelandic bishops in need of financial assistance from the archbishop and the exemplary anecdote of the two elite clerics who were sent on a mission to the archbishop highlight the way in which many of these themes were used not only in the very narrowly stylised motif of the young man travelling to Norway for the first time, but also in accounts of journeys to Norway serving very different purposes. While these accounts differ in many respects from the young man's first journey to Norway, they share an interest in the personal relationship between the Icelandic cleric and the archbishop, as well as a strong sense of hierarchy, with the archbishop as guide, provider, and benevolent lord. They also share an interest in learned clerical values, most notably canon law in both its study and practice.

\subsection{Conclusion}

In this chapter, I have described the relationship between the Icelandic and Norwegian Church through a study of individual agents. I have shown how Icelandic clerics travelled to Norway as part of their careers, working for a Norwegian patron, or their bishop in Iceland, or for no one but themselves. From this study it has become clear how closely these voyages to Norway were connected to other aspects of elite clerical identity. We find many aspects of learned clerical identity woven into narrative accounts of voyages to Norway, especially the importance of canon law, Latinity, and the written word. Additionally, the voyage to Norway was integrated into the ideal career of an elite cleric: service to a Norwegian patron, and in rare occasions the receipt of a Norwegian benefice were seen as formative aspects of a young cleric's early career. Additionally, what was highlighted throughout any discussion of Norway and the Norwegian Church was the possibility and the importance of personal connections between Icelandic clerics and the highestranking members of the Norwegian Church. 


\section{Chapter Six}

\section{Conclusion: The Sub-Episcopal Elite Priests in the Fifteenth and Sixteenth Centuries}

In the preceding chapters, I charted the development of an elite clerical identity in fourteenth-century Iceland. I have examined that identity through the production of religious literature and administrative writing, through the changing structure of Icelandic ecclesiastical administration, through the development of a beneficial system in Iceland, and through relations between elite Icelandic and Norwegian clerics. In the process, I have demonstrated that elite Icelandic clerical culture was a complex amalgam of learned, ecclesiastical culture and long-standing Icelandic customs, adapted to suit this new clerical milieu.

This newly significant group, the sub-episcopal elite, grew in part out of two major political developments. The first was the establishment of a beneficial system in Iceland after Bishop Árni’s 1269-97 staðamál. After the staðir became benefices in the gift of the bishops, they were given to priests, for whom the staðir became effectively a manor or home-farm, producing a small but important class of landholding clerics. The second development was the shifting of power from Iceland to Norway in the middle of the thirteenth century: the submission of Iceland to the king of Norway in 1262-64 and subsequent rise of administrative positions in the secular governance of Iceland, and the 1237 decision to give the archbishop of Niðarós the power to appoint bishops. This in turn led to a large majority of bishops being appointed out of Norwegian clerical positions. Thus, as direct authority shifted from Icelandic leaders to Norwegian ones, the Icelandic ecclesiastical elite, much like the secular aristocrats, took on and augmented the roles of administrators.

This concluding chapter is divided into two broad sections. The first briefly surveys the history of the Icelandic Church from 1400-1550, with a focus on the growth of ecclesiastical administration and the role of the sub-episcopal elite in this period. It places the fourteenth-century growth of elite clerical identity in the broader context of later developments in the late medieval Icelandic Church. The second section outlines some of the thematic emphases of this project, and places my work in the context of a few of the wider debates surrounding the study of the medieval 
Iceland: in particular, the role of nationalist scholarship, and the troubled relationship between saga scholarship and documentary sources.

\subsection{The Sub-Episcopal Elite in the Fifteenth and Sixteenth Centuries}

Clerics in the fourteenth century created strong networks of relationships with other Icelandic elite clerics, with bishops, and even within the Norwegian Church. They carved out a place for themselves in the administration of the diocese by developing the roles of the diocesan officers, and by emphasising and enhancing the role of the mestháttar prestar in an advisory and supportive capacity within the diocese. At the same time, they fostered and maintained a close relationship with Norway, the Norwegian Church, and with elite Norwegian clerics.

By the end of the fourteenth century, however, Scandinavian politics had changed entirely. As a result of the dynastic crises of 1319 to 1397, Norway became politically subordinate to Denmark after 1380. Iceland and the other North Atlantic Norse territories became increasingly irrelevant to the Danish crown, and the personal connection which had existed between Icelanders and the kings of Norway, if only in the Icelandic imagination, dissolved. In the ecclesiastical sphere as well, Icelandic dependence on the Norwegian Church weakened after 1380. From 1380 to 1442 (1464 in Skálholt) Icelandic bishops were appointed by the papacy, not by the archbishop of Niðarós. The papally-appointed bishops are the least well-known of all the bishops in Iceland. In many cases, even the bishops' full name is unknown, as for instance, the mysterious Jón, bishop of Skálholt from 1406-13. ${ }^{1}$ These bishops were also the most nationally diverse group of bishops; many were Danish, while others were English, Dutch, or German, and many, such as Bishop Pétr of Hólar (13911411) came to Iceland from positions as far away as Rome. ${ }^{2}$ In the same way that the secular Icelandic aristocracy saw their personal relationship with Norway fade into irrelevancy, the elite clergy faced a massive shift in the political structure of the Church hierarchy at the episcopal and archiepiscopal levels.

\footnotetext{
${ }^{1}$ On the Icelandic Church in the fifteenth century, see especially Björn Porsteinsson and Guðrún Ása Grímsdóttir, 'Enska Öldin', pp. 33-66 and 124-40; on the papally-appointed bishops, see especially pp. 40-42.

${ }^{2}$ Lögmannsannáll, p. 284; see also Chapter 4.4.3.
} 
At the same time, it should not be assumed that Icelandic clerical networks and personal relationships with their bishops ended abruptly in 1380 (1391 in Hólar) with the arrival of the first papally-appointed bishops. I have already discussed Flateyjarannáll's account of the arrival of Bishop Pétr Nikulásson at Hólar in 1391. The annal suggested a sense of nervousness at the arrival of the unknown bishop, and a fear on the part of the local elite of losing their positions. It highlighted the foreign nationalities of his servants, and described in relieved detail all the diocesan officers and beneficed clergy who kept their offices and honours after the arrival of the bishop. At the same time, the evidence of Flateyannáll also suggests that Bishop Pétr could and did integrate into the structures and personal networks at Hólar.

The same can be said about Bishop Vilchin of Skálholt (1391-1405), who oversaw the production of the monumental collection of máldagar known as Vilchinarbók, built up the cathedral of Skálhólt and the convent of Kirkjubær, in addition to a number of other improvement projects. ${ }^{3}$ He was also the subject of a glowing obituary in $N y$ Annáll, the continuation of Einarr Hafliðason's Lögmannsannáll. ${ }^{4}$ The annal's interest in the death of this bishop, and its eulogistic tone, suggests that Bishop Vichin, at least, was well-integrated into Icelandic clerical networks, and had supporters and followers amongst the clergy at Skálholt. ${ }^{5}$ These bishops were not operating outside of the Icelandic clergy's networks of friendship, patronage and personal connections. How exactly they were connected to these networks and to the social networks which made up the Norwegian and Icelandic Church remains a matter for further study.

Although the end of the fourteenth century saw significant changes to the ecclesiastical hierarchy of the Icelandic and Scandinavian Church, these changes do not seem to have entirely destroyed the importance of personal networks and connections between Icelandic priests and the bishops they served. How these networks were maintained and expanded is a topic that warrents future study, and particularly how they adapted to accommodate bishops arriving from so many different countries and backgrounds.

\footnotetext{
${ }^{3}$ On the Vilchinarbók, see Margaret Cormack, The Saints in Iceland, p. 26. The collection can be found in DI IV, pp. 38-289.

${ }^{4}$ Lögmannsannáll (Ný Annáll), pp. 287-88.

${ }^{5}$ Although Vilchin was not a papally-appointed bishop, being appointed by Archbishop Vinalda. See Björn Porsteinsson and Guðrún Ása Grímsdóttir, ‘Enska Öldin', pp. 50-51.
} 


\subsubsection{Diocesan Officers: $1400-1550$}

Throughout the fifteenth century, the diocesan officers continued to play an important role in the administration of the Icelandic Church. Ný Annáll described a number of officiales and ráðsmenn between 1401 and $1430 .{ }^{6}$ One entry dated to 1430 highlights the importance of these officials. In this year the ráðsmaðr Einarr Hauksson died, after having been ráðsmaðr for 'seventeen years uninterrupted and half a year more'. ${ }^{7}$ The annalist continued by complaining that, 'then the holy church at Skálholt was in such grief and affliction that we do not know that there had ever been before, first without a bishop, and with an old, blind officialis, and then to lose that ráðsmaðr who was both suitable and loyal'. ${ }^{8}$ The diocesan hierarchy is here made explicit, and a diocese without a bishop, with an incapacitated officialis and no ráðsmaðr was a diocese in dire shape.

The power and social importance of the diocesan officers can be seen most clearly by the end of the fifteenth century. After 1442 (1446 in Skálholt), the bishops of Skálholt and Hólar were appointed again by the archbishop; shortly thereafter, the power to appoint Icelandic bishops passed to a priests' synod within Iceland. The majority of the Icelandic bishops to be appointed in this way were members of the beneficed elite clergy, and a large number of them had held diocesan office. The first Icelandic bishop of Skálholt for over 150 years, Sveinn spaki Pétursson (1466-76) acted as officialis of Skálholt under his predecessor, Jón Stefánsson Krabbe (146265). ${ }^{9}$ The last Catholic bishop of Hólar, Jón Arason (1524-50), had been provost in Eyjafjörður, and ráðsmaðr of Hólar before being elevated to the episcopate. ${ }^{10}$

In addition to the diocesan officers, the incumbents of the large staðir also began to be elected as bishop after that power returned to Iceland. The first bishop to be nominated for the episcopacy by a council of Icelandic priests, Óláfr Rögnvaldsson (Hólar: 1459-95), was the incumbent of Breiðabólstaður í Vesturhópi

\footnotetext{
${ }^{6}$ See Appendix 2.

7 'seytian aar samfleytt ok halft aar betur', Lögmannsannáll (Ný Annáll), p. 295.

8 'var ba heilug Skalholltz kirkia j puilikum hormvm oc svtvm sem alldri fyrr vissvm vier ordit hafa. fyst byskups laust. enn officialis gamall oc blindur. enn mistv sidan raads manninn pann er boodi var stadnum hallkvoomur oc hollur', Lögmannsannáll (Ný Annáll), p. 295.

${ }^{9}$ DI V, pp. 425-27.

${ }^{10}$ Vilborg Auðun Ísleifsdóttir, Siðbreytingin á Íslandi, p. 90.
} 
(in 1449) and of Oddi í Rángárvöllum, which he received in $1453 .{ }^{11}$ This made him the first member of the local elite clergy to be made bishop since the death of Bishop Egill Eyjólfsson in 1342, although he was also a member of a prominent Norwegian family of episcopal elites. ${ }^{12}$ Thus, at the end of the fifteenth century, the most powerful members of the Icelandic elite, whose power previously had been limited to diocesan administration at the sub-episcopal level, and control over the wealthiest benefices in Iceland, could once again aspire to be bishop. For these, the first Icelandic bishops in Iceland since the early fourteenth century, the example of Bishop Lárentius, Egill Eyjólfsson, and the other Icelandic bishops who carved out a place for themselves amongst a largely foreign ecclesiastical elite, may have been quite powerful.

\subsubsection{Texts and Literature After 1400}

In Chapter 2, I described two periods of concentrated religious writing, including bishops' sagas. The first period, centred around Skálholt in the period directly after 1200, focused on the bishops of Skálholt and Iceland's first two native saints, St Pórlákr Pórhallsson, bishop of Skálholt 1178-93 and St Jón Ögmundarson, bishop of Hólar 1106-21. The second period of religious writing took place primarily in the north of Iceland, especially at the bishopric of Hólar and the monastery of Pingeyri, and focused strongly on the figure of Guðmundr Arason. Other literature produced at this time included Christian skaldic poetry, new lives of St Porlákr and St Jón Ögmunarson, as well as the more historical Lárentíus saga, and annals. Both of these periods of religious writing can be tied to ideological and social changes in the makeup of the Icelandic Church. At the turn of the eleventh century, the Church began the long and difficult process of breaking from the control of the secular aristocracy, while in the fourteenth century it began to adapt to a fully beneficial church system, after the successes of Árni Porláksson's staðamál. Additionally, these two periods of ecclesiastical reform and religious writing were not independent of each other. Pórláks saga, in particular, took on renewed importance as Bishop Pórlákr's struggles with Jón Loftsson over lay ownership (or patronage) of the staðr

\footnotetext{
${ }^{11}$ Björn Porsteinsson and Guðrún Ása Grímsdóttir, ‘Enska Öldin’, p. 26.

${ }^{12}$ Ibid., p. 26.
} 
at Oddi near the end of the eleventh century resonated with priests struggling for control of the staðir in the late thirteenth century.

The third and final phase of intense production of religious written material took place in the decades before the death of Bishop Jón Arason, on the eve of the Reformation in Iceland. In her study of the hagiographic compilation Reykjarhólarbók, Marianne Kalinke argued that the sixteenth-century manuscript had been compiled, and its saints' lives translated from Low German in the early sixteenth century with the goal of preserving these saints' lives. ${ }^{13}$ Similarly, the editors of the recent volume of Christian skaldic poetry pointed to the high percentage of Christian skaldic poetry, primarily dating to the fourteenth century, which was copied into manuscripts dating to the early sixteenth century in the north of Iceland. They suggested that the interest in this material may well have been a result of the coming Reformation. ${ }^{14}$ The increased interest in copying religious poetry is evidence that copyists working in the diocese of Hólar were attempting to preserve Catholic literature through copying projects. ${ }^{15}$

Similarly, in the early sixteenth century, two copies were made of Lárentíus saga, both in the north of Iceland. The two oldest manuscript copies of Lárentíus saga date from the early fifteenth century. The first manuscript, AM 406 a I, 4to (A) is dated to around 1530 and may have been produced by Síra Tómas Eiríksson, a priest and ráðsmaðr of Hólar at the time of Jón Arason. ${ }^{16}$ Tómas was the incumbent of Mælifell in Skagafjörður, and later appointed abbot of Munkapverá in 1546, its last abbot before the Reformation dissolved the monastery. Tómas' concubine was Póra Óláfsdóttir, a stepdaughter of Jón Arason, making him closely connected to the bishop, both through his office as ráðsmaðr and by marriage. The second sixteenthcentury manuscript, AM 180 b, fol. (B), is dated to around 1500 and was written by an unknown scribe, and possibly multiple scribes. While manuscripts were discovered at Hólar in the seventeenth century, Guðrún Ása Grímsdóttir has argued from textual evidence that AM 406 a I, 4to (A) was produced at the friary of

\footnotetext{
${ }^{13}$ Marianne Kalinke, The Book of Reykjahólar, especially pp. 24-37.

${ }^{14}$ Margaret Clunies Ross, 'Introduction', in Poetry on Christian Subjects, p. xliv.

${ }_{16}^{15}$ Ibid., p. xliv.

${ }^{16}$ See Ârni Björnsson, 'Inngangur', Laurentius saga biskups (Reykjavík: Handritastofnun Íslands, 1969), pp. ix-lxxi (pp. ix-xi). For a summary of the manuscript history of Lárentíus saga, see also Guðrún Ása Grímsdóttir, 'Formáli', in Biskupa Sögur, III, pp. lviii-vx.
} 
Möðruvellir and AM 180 b, fol. (B) was produced at Hólar. ${ }^{17}$ There is still little known about the production of these two manuscripts, and the intellectual milieu in which they were produced. However, it seems likely that Lárentíus saga, the life of an Icelandic-born, Catholic bishop of Hólar would have appealed to the followers of Jón Arason.

Lárentíus saga describes a bishop who was belligerent, pugnacious and stubborn in the service of the Church. It was this stubbornness which made him an ideal candidate for bishop of Hólar, as his predecessor Bishop Auðunn rauði makes clear in a speech to Archbishop Eiliffr, both of whom had quarrelled with Lárentius in the past:

You ought to value the benefit of the holy church, that such men should be chosen to govern the bishop's power, more highly than [the fact] that some injuries were done to us; and it is also fittest and most right before God that we repay him [Lárentius] with this [the office of bishop] if we have been offensive to him in some matters. Lárentius is not to be blamed for simply doing the bidding of his master'.

Meira eigi pér at meta nauðsyn heilagrar kirkju at slíkir menn velist til stjórnar byskupsligs valds heldr en nokkora meingjörð okkr veitta; er pað ok makligast ok réttast fyrir Guði at ef vér höfum í nokkorum greinum offara orðit við hann at bæta pat með pessu; er Lafranz eigi kunnandi pess, pó at hann gjörði boðskað síns herra'. ${ }^{18}$

Here, Bishop Auðunn articulates a view which was held throughout the saga: it was Lárentius' strength and uncompromising stubbornness that made him the most suitable candidate for bishop, and which later made him a good bishop. This view must have appealed to supporters of Bishop Jón Arason, who himself developed a reputation for uncompromising stubbornness in the service of the Catholic Church, as he fought against the arrival of Lutheranism, and indeed, for control over Iceland. ${ }^{19}$ While the reception of Lárentíus saga has not yet been studied in any detail, this is a topic which would benefit from further study, particularly as regards sixteenth-century interest in Bishop Lárentius as a prefiguration of Bishop Jón Arason.

\footnotetext{
${ }^{17}$ Guðrún Ása Grímsdóttir 'Formáli', in Biskupa Sögur, III, pp. xciv-c.

${ }^{18}$ Lárentíus saga, pp. 346-47.

${ }^{19}$ Vilborg Auður Îsleifsdóttir, Siðbreytingin á Íslandi, pp. 89-96.
} 


\subsection{Foreign Bishops, Ecclesiastical Administration, and Narrative Sources}

In this section, I will address three specific issues which have been hinted at throughout this study: foreign bishops, ecclesiastical administration, and what I am calling 'false accounts', odd stories and retellings of fourteenth-century events. These three issues tie in to some of the broader themes which I have explored over the course of this study. Nationalism and the relationship between Iceland and Norway after 1264, ecclesiastical hierarchies and the relationship between the Icelandic Church and the International Church, and the place of the fourteenth century and the late Middle Ages in Icelandic literary history are themes which have been of interest not only to historians of the fourteenth century, but also more broadly within the field of Old Norse-Icelandic Studies. Moreover, these three issues: foreign bishops, ecclesiastical administration and false accounts highlight three areas in which my approach has created new perspectives on old problems in Old Norse-Icelandic Studies. I have approached the study of administrative history as a history of individual agents and have used a combination of literary criticism and traditional historical methodology to approach texts which have traditionally not been the subject of such study as agents in the historical process.

\subsubsection{Foreign Bishops}

One of the most prevalent debates in the history of the fourteenth-century Icelandic Church is the question of the 'foreign bishops'; the Norwegian, Danish, English, German, and Dutch clerics who were appointed bishops of Hólar and Skálholt from 1238 to 1442 . These bishops have been harshly criticised, and their conflicts with the Icelandic farmers have been interpreted as a struggle for independence against the tyranny of the foreign bishops. This interpretation has also coloured readings of Lárentíus saga. The saga has been interpreted as a criticism of foreign bishops, especially in its depiction of Bishop Auðunn. ${ }^{20}$ J.H Jørgensen, in his introduction to

20 J.H.Jørgensen, 'Forord', in Historien om biskop Laurentius på Holar trans. by J.H.Jørgensen (Odense: Odense universitetsforlag, 1996), pp. 7-36 (pp. 22-28). See also Guðrún Ása Grímsdóttir, ‘Formáli’, p. lxxix. 
the Danish translation of the saga, pointed to Bishop Lárentius' dying request to the archbishop of Niðarós that he appoint 'an Icelandic bishop rather than a Norwegian because the local situation (landskapr) is more familiar to them'. ${ }^{21} \mathrm{He}$ argued that this exemplified the author's antipathy towards Norwegian bishops, particularly the bishops of Hólar and Skálholt in the 1340s. ${ }^{22}$ While it is likely that Einarr Hafliðason disliked Bishop Ormr Áskáksson, to generalise from this personal relationship to infer a general distrust of all Norwegian bishops is highly problematic and ignores the role of individual antagonisms and conflicts in developing personal networks and connections.

Analysis of the evidence for the careers of the foreign bishops in Iceland from 1313-80 suggests a strong dedication to diocesan affairs. There are no instances of absenteeism among the seven foreign bishops of Skálholt and the three foreign bishops of Hólar; the only one of their number who never set foot on Iceland was Bishop Grímr Skútason (1321), who died in the summer of the year he was appointed and consecrated as bishop of Skálholt. The primary evidence to suggest that the foreign bishops were irresponsible are the numerous accounts of their conflicts with laypeople, and occasional disputes with the clergy of Iceland. As Magnús Stefánsson made clear, these disputes actually show a dedication to the service of the Church, as these were primarily disputes concerning the rights of the Church. ${ }^{23}$ Magnús Stefánsson argued that even Bishop Ormr Ásláksson, so disliked by his contemporary Einarr Hafliðason and later historiography, showed no lack of responsibility, but rather worked to advance the interests of the Church. ${ }^{24}$ Lára Magnúsardóttir more recently argued that the foreign bishops, though they made use of the tool of excommunication to exert control over laypeople, never went beyond the bounds of their canonical rights in their threats of excommunication. She suggests an alternate reading in which the frequent threat of excommunication can be seen as evidence for a strong belief in canonical process, which did not allow a bishop to pass a ban of excommunication without giving clear warning of his

\footnotetext{
21 'íslenzkan byskup en norrænan sakir pess at peim er kunnigri landskapr', Lárentíus saga, p. 441; Jørgensen, 'Forord', in Historien, pp. 24-25.

22 Jørgensen, 'Forord', in Historien, pp. 24-26. See also Sverrir Tómasson, Íslensk bókmenntasaga, I, p. 354, and Guðrún Ása Grímsdóttir, 'Formáli', p. 1xxix.

${ }^{23}$ Magnús Stefánsson, 'Frá goðakirkju', especially pp. 248-53.

${ }^{24}$ Ibid., pp. 250-52.
} 
intention to do so. ${ }^{25}$ In spite of these vigorous assaults on the model of the 'bad foreign bishops', it remains a prevalent theme, particularly in interpretations of Lárentíus saga.

In his discussion of Norwegian bishops in the Icelandic Church, Magnús Stefánsson emphasised that identifying the Norwegian bishops primarily through their national identity was misguided. He highlighted instead thirteenth- and fourteenth-century bishop's dedication to libertas ecclesiae, and argued that for these bishops, it was the interests of the Church, rather than national interests, which were paramount. $^{26}$ My own study of Icelandic clerics in Norway has taken this interpretation even further. While the bishops appointed by the archbishop of Niðarós from 1313-90 held clerical positions in Norway, and came from that country, it is not clear that they were seen by their contemporaries as foreigners, as a group set apart from other bishops and clerics by their nationality. Contemporary writers emphasised connections between Icelandic and Norwegian clerics, dwelling on friendships between Icelandic clerics and powerful Norwegian canons, bishops and archbishops. The Norwegian bishops are not described as such in contemporary sources, with the single exception of Bishop Lárentius' dying request to the archbishop of Niðarós. This in turn might more productively be interpreted as an attempt to ensure the appointment of Lárentius' preferred successor, the Icelandic priest Egill Eyjólfsson. Contemporary clerical sources make no mention of difficulties of language, custom or other markers of foreignness in regards to the Norwegian bishops in Iceland. In this, fourteenth-century depictions of Norwegian bishops display significantly less interest in differences between Norwegians and Icelanders than even their contemporary Íslendingasögur, which often depicted Norwegian visitors to Iceland as outsiders, buffoons, and broad stereotypes. ${ }^{27}$

In this project, I examined the relationship of the Icelandic and Norwegian Church as a history of individual agents. Icelandic priests travelling to Norway showed a remarkable level of integration into Norwegian clerical social networks and Norwegian networks of patronage. In many cases, such as those of Bishop Jón Halldórsson of Skálholt, Bishop Auðunn rauði of Hólar, and his grandson Eysteinn

\footnotetext{
${ }^{25}$ Lára Magnúsardóttir, Bannfaring og kirkjuvald, pp. 160-74, 214.

${ }^{26}$ Magnús Stefánsson, 'Frá goðakirkju', p. 253.

${ }^{27}$ Sverrir Jakobsson, 'Strangers in Icelandic Society 1100-1400', Viking and Medieval Scandinavia, 3 (2007), 141-57.
} 
rauði, this integration was so complete that their very identification as Icelandic or Norwegian has become blurred. Bishops from Norwegian clerical backgrounds nevertheless managed to develop complex and meaningful relationships with the Icelandic clerical elite. Conflicts between individual members of the clerical elite and the bishops, moreover, should not be seen as evidence of Icelandic hatred for foreign bishops, but rather as further proof of their total integration into local networks.

\subsubsection{Ecclesiastical Administration}

In this study, I have focused in some detail on the administration of the Icelandic Church, particularly at the diocesan level, and sub-episcopal level, that is to say the officers and elite priests who administered the diocese under the direction of their bishop. In the process, I have illustrated the importance of ecclesiastical administration to elite clerical identity. Icelandic clerics participated keenly in diocesan administration, and the diocesan officers became powerful, as their offices developed into respected positions. Writers such as Einarr Hafliðason and the annalists focused their attention on matters of diocesan administration and the role of good relations between the bishop and the mestháttar prestar in diocesan management. Administrative and legal matters such as letter-writing and recordkeeping, the granting of formal dispensations, and obedience to canon law increasingly became the focus of Icelandic clerical writing. This suggests that ecclesiastical administration was important in the minds of the elite, beneficed clergy in Iceland in the fourteenth century, and a significant part of elite clerical identity.

Recent work on religion and the Church in Iceland and elsewhere has been particularly interested not in ecclesiastical administration, but rather in the cultural and personal aspects of devotion: ritual, belief, piety, saints' cults, and other aspects, both interior and public, of popular belief. ${ }^{28}$ These are incredibly important areas of

\footnotetext{
${ }^{28}$ Ásdís Egilsdóttir, 'Jarteinir, líkami, sál og trúarlíf'; Margaret Cormack, The Saints in Iceland; Ármann Jakobsson, 'The Friend of the Meek'. See also the recent collection of essays on saints' cults and sanctity, Thomas DuBois, ed., Sanctity in the North: Saints, Lives, and Cults in Medieval Scandinavia (Toronto, ON: University of Toronto Press, 2008). Outside of Iceland, this field is too wide to do it justice, and I will only mention two works that I found particularly memorable: Caroline Walker Bynum, Wonderful Blood: Theology and Practice in Late Medieval Northern Germany and Beyond (Philadelphia, PA: University
} 
research, and allow access to the mental and cultural landscape of the Middle Ages. Elements of piety and worship can also be found in fourteenth-century clerical narrative, sometimes side by side with descriptions of ecclesiastical administration. The description of Bishop Lárentius' deathbed admonishment to his pupils Egill Eyjólfsson and Einarr Hafliðason that they hold the Hours of the Holy Spirit (heilags anda tíðir) every day of their lives as he had, for instance, was written together with a description of the bishop's diligence in arranging the details of his succession and the administration of the diocese in the intervening period. ${ }^{29}$ Indeed, one avenue of future research might be to examine the role of piety and personal devotion as a motivating factor in promoting the administrative structure of the Church.

In contrast to such studies of the cultural and spiritual aspects of religion in the Middle Ages, a study of ecclesiastical bureaucracy runs the risk of becoming sterile, even cynical. The administration of the Church is sometimes seen in opposition to devotion, and administrators and canon lawyers as cynical, calculating manipulators of devotion and piety in service of profit and power. ${ }^{30}$ Additionally, there is a methodological divide. Devotion and lay piety have become important matters for study as a result of an increasing number of studies influenced generally by postmodern thought, and more particularly by the history of mentalities and emotion. Ecclesiastical administration, on the other hand, has not yet been studied in the same way. Most studies of diocesan administration, especially studies of the diocesan officers, remain firmly in the empirical tradition of ecclesiastical history, and focus on aspects of administration such as institutional developments, canon law and its application, and the origin of the role of the diocesan officers. What has been ignored in this approach are contemporary attitudes towards diocesan administration, its role in creating an elite community of administrators, and the role of diocesan

of Pennsylvania Press, 2007), and Patrick Geary, Living With the Dead in the Middle Ages (Ithaca, NY: Cornell University Press, 1994).

${ }_{29}^{20}$ Lögmannsannáll, p. 270; see also Lárentíus saga, p. 312. This may refer to the votive office (Officium de sancto spiritu) added to monastic/clerical devotion starting from the late thirteenth century or even earlier. A short type became standard in later Books of Hours, from the second half of the fourteenth century. For the sequence and text of the office, see the Centre for Håndskriftstudier i Danmark, 'Tutorial on Books of Hours', <http://www.chd.dk/ tutor/spiritusmh.html>, accessed 9 November 2011.

${ }^{30}$ But see for instance a recent study on indulgences for a nunaced view of the relationship between popular piety and bureaucracy; R.N. Swanson, ed., Promissory Notes on the Treasury of Merits: Indulgences in Late Medieval Europe (Leiden: Brill, 2006). 
administrators themselves in creating and developing the office through the manipulation of memory and of the past.

\subsubsection{Narrative, Fourteenth-Century Sources, and False Accounts}

Throughout this work, I have made an effort to highlight a variety of folk traditions, literate re-workings, and fictionalised accounts of fourteenth-century events, wherever they appear relevant. Some of these accounts have been repeated elsewhere and a few of them (in particular the legends and stories surrounding the thirteenthcentury Bishop Guðmundr Arason) have been the focus of limited study. ${ }^{31}$ The majority of these 'false accounts' however, have been used only as colourful anecdotes, if mentioned at all.

I have argued, primarily in the context of Lárentíus saga and other written narratives, that individual people's constructions of their own lived past, or that of their families, friends, or communities, can be analysed in their own right. In this study of clerical identity, I have investigated the role of personal or constructed narrative primarily in the context of bishops' sagas, and other forms of clerical writing. I have argued that false or conflicting accounts in particular can be used to reveal the significance of a given event to the people who experienced it. Over the course of my research however, I have encountered a number of what I am calling false accounts: fictionalised re-workings of events or people encountered elsewhere in my research, which I have tried to incorporate into my study.

It is particularly intriguing to note how particular events provoked so much writing, so many different interpretations, and so many impassioned interpretations, while others, seemingly more relevant, were not subject to the same colourful reworkings (I am thinking here particularly of the submission to the king of Norway in 1262-64). One episode which illustrates this clearly, I think, is the Battle of Grund in 1362, and the accompanying conflict between the priests of Eyjafjörður and Bishop Jón skalli. In modern scholarship, the Battle of Grund is not a particularly well-known episode in Icelandic history. In the second half of the fourteenth century however, it was the subject of numerous tellings and re-workings, many of them

31 See for instance Marlene Ciklamini, 'Folklore and Hagiography in Arngrímr's Guðmundar saga Arasonar'. 
remarkable and unique examples of their kind. The stories, learned projects, dirty poems, contradictory accounts, and lasting personal legends provide insight not only into the details of the event itself, but more importantly into the meaning of the event for the people involved. Unfortunately, the only study to date which has seriously attempted a comparative study of annalistic accounts of the Grundarbardagi attempted only to reconstruct the 'real' events through a comparison of the different accounts; this attempt is useful in its own way, but ignores the real value of so many different contemporary accounts. ${ }^{32}$

The specific details of each account can tell us about individual attitudes towards the event. The whole of the corpus however, speaks to the multiplicity of voices, of opinions and of narratives describing this event. It is the presence of this multiplicity of narratives, and of narrative and non-narrative genres, that makes fourteenth-century sources such a spectacular and drastically underutilised font of remarkable and unusual stories and remnants, and I have tried to highlight this uniqueness throughout this work.

It is particularly important to note this multiplicity of narratives, and richness of contemporary interest in fourteenth-century events in the light of current historiographical misconceptions about the fourteenth century, and about the late Middle Ages more generally in Iceland. As I have shown, one of the most pervasive misconceptions about fourteenth-century Iceland is that it is lacking in sources. This perceived lack of source material is then tied to the supposed poverty of Icelandic culture at this time. Thus, late medieval Iceland was boring, 'silenced', devoid of feud or major warfare, and generally unworthy of study. When stories, creative reworkings, and false accounts are taken into consideration, this view of late medieval Iceland as boring and lacking in narratives about its history is seen to be false.

Additionally, modern historiography has often seen late medieval Iceland as fundamentally different from high medieval Iceland. In particular, it is characterised as lacking the unique features that made high medieval Iceland special: independence, a goð $i$ system, feuds and localized warfare, and so on (as described in Chapter 1.1). In part, this is due to the changing nature of the source material, the perceived waning of saga-writing by the fourteenth century, and the rise of documentary sources after the mid-fourteenth century. These two types of sources

\footnotetext{
${ }^{32}$ This study is Einar Bjarnason's, ‘Árni Pórðarson'; see also Chapter 1.3.2.
} 
are very different, and do produce different types of evidence: to take a very basic example, the documentary record tells us a great deal about property, landownership, currency, and the precise contents of every parish church in Iceland, all information which cannot be found in a saga. However, to argue for a fundamental shift in society from a change in the types of sources available is problematic. Moreover, to argue that the only sources of information for the late Middle Ages are these documents is to ignore the wealth of narrative material from this period.

Using the bishops' sagas in particular, I have shown that while Icelandic culture did change after 1300, there were many points of continuity as Icelandic clerics, for instance, worked to position themselves within a tradition of saga-writing and saga heroes. The stories, fictionalised accounts, and legends which I have highlighted throughout this thesis point to the same sense of narrative continuity. When Ólöf Loftsdóttir, the widow of the hirðstjóri Björn Porsteinsson was said to have cried, after Björn's murder by English merchants in 1467, 'let us not cry for Björn, but gather troops', she is speaking in the language of a heroic past. ${ }^{33}$ The legend surrounding Ólöf’s near contemporary, Margrét Vigfúsdóttir (c. 1406-86) speaks even more clearly to this later use of heroic tropes. According to the legend, Margrét's brother Ívarr hólmr Vigfússon, the hirðstjóri, was burned in his home by agents of the infamous bishop Jón Gerreksson. Barely escaping with her life (she was living with her brother at the time), Margarét vowed to marry none but the man who avenged her brother's death. ${ }^{34}$ This is a heroic saga-style story, of a hero burned in his home and a woman determined to achieve revenge for the death of her brother. At the same time, it takes place in 1430, and the people it describes are real people. Much is known about the hirðstjóri Ívarr Vigfússon, while the more prosaic details of Margarét's marriage to the wealthy aristocrat Porvarðr Loftsson in 1436, her children and her subsequent widowhood, have been well-preserved. ${ }^{35} \mathrm{We}$ are used to thinking of the history of Iceland as a progression from the semi-mythic to the real, as the sources 'progress' from the ahistorical Íslendingasögur which chronicle the early centuries $(800-c .1200)$, to the arguably historical Sturlungasaga (thirteenth

\footnotetext{
${ }^{33}$ Gunnar Karlsson, Iceland's 1100 Years, p. 121.

${ }^{34}$ Vatnsfjarðarannáll elzti, in Annálar 1400-1800, IV, p. 26. Björn Porsteinsson places this episode and particularly the subsequent killing of Jón Gerreksson in the context of developing tensions with English merchants, Enska Öldin, pp. 131-35; see also Björn Porsteinsson and Guðrún Ása Grímsdóttir, 'Enska Öldin', pp. 57-59.

${ }^{35}$ Agnes Arnórsdóttir, Property and Virginity, pp. 253, 364-65, 392.
} 
century), to the comfortingly secure historical value of documentary evidence for the fourteenth century and later. The juxtaposition of the contemporary evidence for Margrét's more prosaic existence (marriage contract, widowhood, disputes over property and inheritance) with the existence of a remarkable heroic story of a woman's revenge disrupts this sense of progression. The richness and variety of fourteenth-century material thus provides compelling evidence for a new literary history of Iceland, one that also has a place for historical approaches, and for the sustained study of documentary material. 


\section{Conclusion}

With this study, I have re-examined the assumption that the history of the Church in Iceland could be characterised by the growth of power, wealth, and influence, culminating politically with the successes of Árni Porláksson's staðamál, and economically with the accumulation of wealth and properties in the late Middle Ages. To examine the meanings of these developments, I moved from structural or institutional approaches, which have characterised discussions of political, economic, and social aspects of the Icelandic Church, and turned instead to a study of individual clerics and their personal networks.

With the successes of staðamál (1269-97), the bishops in Iceland created a beneficial system in the country. The benefits of this system to the Church, and to the bishops are well-established; what I have attempted to describe here are the benefits of this system to the elite clerics who became the incumbents of these benefices, which represented roughly a third of the parish churches in Iceland. It is unclear whether these priests came from wealthy or powerful families before the success of staðamál, or whether they represented a neuveau riche; as in the case of the secular elites, there may have be an element of both. Moreover, it remains unclear how definitive a break staðamál represented from earlier practices. Some of the staðir may already have been functioning as benefices in the years before 1269 , although others were the focus of bitter debate in the last half of the thirteenth century. What can be determined however, is that the advent of a beneficial culture in Iceland made householders of those priests who held staðir as benefices, giving them both status as elite landholders, and income from the staðir and dependent properties.

Over the course of the fourteenth century, these benefice-holding clerics, together with the younger priests who aspired to this status, developed an elite clerical culture, one which excluded lower-status clerics as much as it did the laity. This culture was relentlessly learned, upholding to the point of fetishising aspects of Christian learning such as Latinity, knowledge of canon law, the legal process, and ecclesiastical administration. Unlike previous generations of Christian scholars, who valued elements of Christian learning such as Biblical knowledge and theology, fourteenth-century clerics valued the jargon and the processional apparatus of the 
law and of ecclesiastical bureaucracy. They had a close relationship with the Norwegian Church, and valued the appearance of a close, personal relationship with the archbishop of Niðarós. On institutional matters, the Icelandic clergy looked to the archbishop to validate local saints' cults, to adjudicate disputes involving Icelandic bishops, to collect papal taxes, and effectively to act in every way as the highest authority in Church matters. In writing, the archbishop was depicted, like many bishops, as a fatherly patron; one who was owed obedience, but who repaid loyalty with friendship, and who interested himself personally in the careers of Icelandic priests. In the mid-fourteenth century, particularly under the influence of Einarr Hafliðason and Snorri kyngir Porleifsson, the first long-term officiales of Hólar and Skálholt respectively, the roles of the diocesan officers began to take on increased significance, becoming one of the defining elements of elite clerical identity.

Over the course of the fourteenth century, the wealth and influence of those elite priests who held the staðir as benefices increased exponentially. By 1400, the wealth of the most powerful priests in the diocese of Hólar lay as much or more in their personal property (land and moveable goods) as it did in the income from their benefices. In landholdings and wealth, their careers reflect closely those of the secular elites of the time; they too were experiencing a steep growth in their wealth, particularly landholdings.

The Church, in Iceland as elsewhere, was constituted by a regionally specific social network, and the individuals who made up that network used institutional structures for their own local and personal purposes. Thus, while the role of the diocesan officers, to take a clear example, was canonically dictated, and probably brought to Iceland from its metropolitan in Niðarós, the significance of the diocesan officers was created entirely by the elite Icelandic clerics who occupied these roles. They shaped the office and may well have been the force driving the establishment of the permanent, stable role of the diocesan officers in the late fourteenth century. Thus, this thesis is not just a study of the structure of the Icelandic Church, but is also an exercise in sociological research, benefitting from and contributing to recent work on social network theory, including work on Icelandic family and social structures.

Methodologically, this thesis has successfully integrated the evidence provided by documentary and narrative sources, while at the same time integrating prosopographical research with cultural and social history. I have thus been able to 
study elite clerical identity from a range of perspectives. This approach has allowed me to highlight the interconnected world of the sub-episcopal elites, and the ways in which religious writing, ecclesiastical administration, and even fantastic literature connected the textual community of fourteenth-century Iceland. In this field, much more remains to be done, including further study of the role of the sub-episcopal elite in the production of exempla, romance, and other fantastic genres of writing, as well as the beginnings of bureaucratic writing in Iceland, and its role in creating a community of administrators and aristocrats.

With its discussion of Norwegian bishops of Skálholt and Hólar and their connections to elite Icelandic clerical networks, as well as discussion of Icelandic priests in Norway, this thesis has started to tell an interesting story of Iceland's relationship with Norway through a history of individual personal networks. Through this focus on individual agents, I am able to describe not only Icelandic economic and political dependence but also issues of cultural identity and relationship to the parent country. Here too, much more work could be done to further refine our understanding of Iceland's relationship with Norway, with the papacy, and with other regions of Europe.

Iceland and the Icelandic Church in the fourteenth century and later Middle Ages remain poorly understood. The historical and bureaucratic writing of this period has not been subject to intensive source criticism, and much remains unknown about their production, textual history, sources, reception, and purpose. The social developments of this period, too, remain understudied, as do ecclesiastical structures. While this neglect has sometimes been explained by arguing that Iceland in the fourteenth century was so closely integrated into Continental European social structures and ecclesiastical practices, and therefore uninteresting, this view has been proven false. The fact that Iceland was well-integrated into fourteenth-century ecclesiastical practice is not an intellectual dead-end, but rather is the beginning of a wide field of inquiry into the conjunction of ideal and praxis and the local application of broader institutional structures. 


\section{Bibliography}

\section{Primary Sources}

Annálar 1400-1800: Annales Islandici posteriorum saculorum, 8 vols (Reykjavík: Félagsprentsmiðjan, 1922-2002)

Ásdís Egilsdóttir, ed., Biskupa Sögur II: Hungrvaka, Porláks Sögu Biskups, Páls saga Byskups, Íslenzk Fornrit, 16 (Reykjavík: Hið íslenzka fornritafélag, 2002)

Bogi Melsteð, ed., Jarðabók Árna Magnússonar og Páls Vídalíns, 10 vols (Copenhagen: Hið íslenska fræðafjelag í Kaupmannahöfn, 1913-1990), VIII (1926)

Cederschiöld, Gustav, Clári saga, Altnordische Saga-Bibliothek, 12 (Halle: Niemeyer, 1907)

Clunies Ross, Margaret, ed., Poetry on Christian Subjects, 2 vols, Skaldic Poetry of the Scandinavian Middle Ages, 7 (Turnhout: Brepols, 2007)

Denis, Andrew, Peter Foote, and Richard Perkins, trans., Laws of Early Iceland: Grágás, the Codex Regius of Grágás, with Material from other Manuscripts (Winnipeg: University of Manitoba Press, 1980-2000)

Diplomatarium Norvegicum, 22 vols (Kristiania: Malling; Oslo: Norsk Historisk Kjeldeskrift-Institutt, 1847-1976), < http://www.dokpro.uio.no/dipl_norv/diplom _field_eng.html > [accessed 8 November 2011]

Einar Hafliðason, 'Atburðr á Finnmörk', in Alfraði Íslenzk: Islandsk Encyclopcedisk Litteratur, 2 vols, ed. by Kristian Kålund (Copenhagen: Samfund til udgivelse af gammel nordisk Litteratur, 1908-1918), I (1908), pp. 57-59

Fell, C.E., ed., Dunstanus Saga, Editiones Arnamagnaeanae, Series B, 5 (Copenhagen: Reitzel, 1963)

Finnur Jónsson, Den Norsk-Islandske Skjaldedigtning: A, Tekst efter håndskrifterne (Copenhagen: Gyldendal, Nordisk forlag, 1912-1915)

Foote, Peter, 'Bishop Jörundr Porsteinsson and the Relics of Guðmundr inn góði Arason', in Studia Centenalia in Honorem memoriae Benedikt S. Pórarinsson (Reykjavík: Ísafold, 1961), pp 98-114 
Gering, Hugo, ed., Íslensk avvintyri: Isländische Legenden, Novellen und Märchen (Halle: Verlag der Buchhandlung des Waisenhauses,1882-1883)

Guðrún Ása Grímsdóttir, ed., Biskupa Sögur III: Árna Saga Biskups, Lárentíus Saga Biskups, Sögupáttur Jóns Halldórssonar Biskups, Biskupa AEttir, Íslenzk Fornrit, 17 (Reykjavík: Hið íslenzka fornritafélag, 1998)

'Guðmundar saga Arasonar', in Biskupa Sögur, ed. by Jón Sigurðsson and Guðbrandur Vigfússon, 2 vols (Copenhagen: Hið íslenzka bókmenntafélag, 1858), II, pp. 1-187

Haraldur Bernharðsson, Magnús Lyngdal Magnússon and Már Jónsson, eds, Járnsíða og kristinréttur Árna Porlákssonar (Reykjavík: Sögufélagið, 2005)

Jón Trausti, 'Veislan á Grund', in Jón Trausti, Góðir stofnar: Sögur frá fyrri öldum (Reykjavík: Kristjánsson, 1914-15). Full text available online at <http://www.snerpa.is/ net/sma/grund.htm>, [accessed 5 November, 2011]

Keyser, R. and P.A. Munch, eds, Norges gamle Love indtil 1387: Ifölge offentlig Foranstaltning og tillige med Understöttelse af det Kongelige Norske Videnskabers Selskab, 5 vols (Christiania: Grøndahl, 1846-95)

Már Jónsson, ed., Jónsbók: lögbók Íslendinga, hver sampykkt var á Althingi árid 1281 og endurnýjud um midja 14. öld en fyrst prentud árid 1578 (Reykjavík: Háskólaútgáfan, 2004)

Munch, P.A., Pavelige Nuntiers Regnskabs- og Dagböger, førte under TiendeOpkravrningen (Christiana: Brögger \& Christie, 1864)

Schulman, Jana K., Jónsbók: The Laws of Later Iceland: The Icelandic Text According to MS AM 351 fol. Skálholtsbók eldri (Saarbrücken: AQ-Verlag, 2010)

Sigurgeir Steingrímsson, Ólafur Halldórsson and Peter Foote, eds, Biskupa Sögur I: Kristni Saga, Kristni Pattir, Jóns saga ins helga, 2 vols, Íslenzk Fornrit, 15 (Reykjavík: Hið íslenzka fornritafélag, 2003)

Stefán Karlsson, ed., Guðmundar sögur Biskups I: AEvi Guðmundar Biskups, Guðmundar saga A, Editiones Arnamagnaeanae, Series B, vol. 6 (Copenhagen: C.A. Reitzel, 1983)

Stefán Karlsson, ed., Islandske Originaldiplomer indtil 1450 (Copenhagen: Munksgaard, 1963) 
Storm, Gustav, ed., Islandske annaler indtil 1578, Det norske hist kildeskriftfando Skrifter, 21 (Christiania: Grøndahl, 1888)

Unger, C.R., ed., Thomas saga Erkibyskups: Fortcelling om Thomas Becket Erkebiskop af Canterbury: To bearbeidelser samt Fragmenter af en tredie (Christiana: Bentzen, 1867)

Porlákr Jónsson, Ólafur Daviðsson and Jón Porkelsson, eds, Diplomatarium Islandicum: Íslenzkt fornbréfasafn, 15 vols (Copenhagen and Reykjavík: Hið íslenzka bókmentafélag, 1857-1972)

\section{Secondary Sources}

Agnes Arnórsdóttir, Property and Virginity: The Christianization of Marriage in Medieval Iceland 1200-1600 (Aarhus: Aarhus Universitetsforlag, 2010)

_- 'Marriage Contracts in Medieval Iceland', in To Have and to Hold: Marrying and its Documentation in Western Christendom, 400-1600, ed. by Phillip L. Reynolds and John Witte, Jr. (Cambridge: Cambridge University Press, 2007), pp. 260-389

Anna Sigurðardóttir, Allt hafði annan róm áður í páfadóm: Nunnuklaustrin tvö á Íslandi á miðöldum og brot úr kristnisögu (Reykjavík: Kvennusögusafn Íslands, 1988)

Andersson, Theodore, The Growth of the Medieval Icelandic Sagas (1180-1280) (Ithaca, NY: Cornell University Press, 2006)

- The Icelandic Family Saga: An Analytic Reading, Harvard Studies in Comparative Literature, 28 (Cambridge MA: Harvard University Press, 1967)

Ármann Jakobsson, 'The Friend of the Meek: The Late Medieval Miracles of a Twelfth-Century Saint', in The Making of Christian Myths in the Periphery of Latin Christendom c. 1000-1300, ed. by Lars Boje Mortensen (Copenhagen: Museum Tusculanum, 2006), pp. 135-51

Árni Björnsson, 'Inngangur', in Laurentius saga Biskups, ed. by Árni Björnsson (Reykjavík: Handritastofnun Íslands, 1969), pp. ix-lxxi

Árni Daníel Júlíussson, Jón Óláfur Ísberg, and Helgi Skúli Kjartansson, eds, Íslenskur Söguatlas, vol. 1 (Reykjavík: Almenna bókafélagið, 1989-93) 
Ásdís Egilsdóttir, 'Biskupasögur og helgar ævisögur', in Biskupa Sögur I: Kristni Saga, Kristni Pattir, Jóns saga ins helga, 2 vols, ed. by Sigurgeir Steingrímsson, Ólafur Halldórsson and Peter Foote, Íslenzk Fornrit, 15 (Reykjavík: Hið íslenzka fornritafélag, 2002), I, pp. viii-Xxx

— , 'Hrafn Sveinbjarnarson, pilgrim and martyr', in Sagas, saints and Settlements, ed. by Gareth Williams and Paul Bibire, The Northern World, 11 (Leiden: Brill, 2004), pp. 29-39

— - 'From Orality to Literacy: Remembering the Past and the Present in Jóns saga helga', in Reykholt som makt- og lardomssenter: I den islandske og nordiske kontekst, Snorrastofa rit, 3 (Reykholt: Snorrastofa, 2006), pp. 215-28

—_, 'Jarteinir, líkami, sál og trúarlíf' in Sagnaheimur: studies in honour of Hermann Pálsson on his 80th birthday, 26th May 2001, ed. by Ásdís Egilsdóttir and Rudolf Simek (Vienna: Fassbänder, 2001), pp. 13-19

Bagge, Sverre, Den kongelige kapellgeistlighet 1150-1319 (Bergen: Universitetsforlaget, 1976)

— From Gang Leader to the Lord's Anointed (Odense: Odense University Press, 1996)

—, 'Aims and Means in the Inter-Nordic Conflicts 1302-1319', Scandinavian Journal of History, 32 (2007), 5-37

_ _ 'Nordic Students at Foreign Universities until 1660', Scandinavian Journal of History, 9 (1984), 1-29

Barrow, G.W.S., 'A Kingdom in Crisis: Scotland and the Maid of Norway', Scottish Historical Review, 69 (1990), 120-41

Benedikt Eypórsson, 'History of the Icelandic Church 1100-1300: Status of the Research', in Church Centres: Church Centres in Iceland from the 11th to the 13th Century and their Parallels in Other Countries, ed. by Helgi Porlaksson, Snorrastofa rit, 2 (Reykholt: Snorrastofa, 2005), pp. 7-71

—, 'Reykholt and Church Centres', in Church Centres: Church Centres in Iceland from the 11th to the 13th Century and their Parallels in Other Countries, ed. by Helgi Porlaksson, Snorrastofa rit, 2 (Reykholt: Snorrastofa, 2005), pp. 105-116

Bjørgo, Narve, 'Om skriftlege kjelder for Hákonar saga', Norsk Historisk Tidskrift, 4 (1967), 185-229 
Björn Teitsson and Magnús Stefánsson, 'Um rannsóknir á íslenzkri byggðarsögu tímabilsins fyrir 1700', Saga, 10 (1972), 134-78

Björn Porsteinsson, Enska Öldin í sögu íslendinga (Reykjavík: Mál og Menning, 1970)

—_ Íslenzka skattlandið, (Reykjavík: Heimskringla, 1956)

—_, 'Síðasta íslenska sagnritið á miðöldum', in Afmaelisrit Björns Sigfússonar, ed. by Björn Teitsson, Björn Porsteinsson and Sverrir Tómasson (Reykjavík: Sögufélag, 1975), pp. 47-72

Björn Porsteinsson, Guðrún Ása Grímsdóttir, 'Enska öldin', in Saga Íslands: Samin að tilhlutan Pjóðhátíðarnefndar 1974, ed. by Sigurður Lindal, 5 vols (Reykjavík: Hið íslenzka bókmenntafélag, 1974-90), V(1990), pp. 3-216

Björn Porsteinsson, Guðrún Ása Grímsdóttir, 'Norska öldin', in Saga Íslands: Samin að tilhlutan Pjóðhátiðarnefndar 1974, ed. by Sigurður Lindal, 5 vols (Reykjavík: Hið íslenzka bókmenntafélag, 1974-90), IV (1980), pp. 61-258

Björn Porsteinsson, Sigurður Líndal, 'Lögfesting Konungsvalds', in Saga Íslands: Samin að tilhlutan Pjóðhátíðarnefndar 1974, ed. by Sigurður Lindal, 5 vols (Reykjavík: Hið íslenzka bókmenntafélag, 1974-90), III (1978), pp. 19-108

Blom, Grethe Authén, Magnus Eriksson og Island: Til belysning av periferi og sentrum $i$ nordisk 1300-talls historie, Det Kongelig Norske Videnskabers Selskab, Skrifter, 2 (Oslo: Universitetsforlaget, 1983)

Boulhosa, Patricia, Icelanders and the Kings of Norway: Mediaeval Sagas and Legal Texts, Northern World, 17 (Leiden: Brill, 2005)

—, 'Of Fish and Ships in Medieval Iceland', in The Norwegian Domination and the Norse World c. 1100-c. 1400, ed. by Steinar Imsen, Trondheim Studies in History (Trondheim: Tapir, 2010), pp. 175-97

Bowsky, William M., A Medieval Italian Commune: Siena under the Nine, 12871355 (Berkeley: University of California Press, 1981)

Brundage, James, Medieval Canon Law (London; New York: Longman, 1995)

Brunner, Otto, Land and Lordship: Structures of Governance in Medieval Austria (Philadelphia, PA: University of Pennsylvania Press, 1992) 
Burger, Michel, 'Officiales and the Familiae of the Bishops of Lincoln, 1258-99', Journal of Medieval History, 16 (1990), 39-53

Byock, Jesse, Medieval Iceland: Society, Sagas, and Power (Berkeley, CA: University of California Press, 1988)

—-, 'Modern Nationalism and the Medieval Sagas', in Northern Antiquity: The Post-Medieval Reception of Edda and Saga, ed. by Andrew Wawn (London: Hisarlik Press, 1994), pp. 163-87

Bynum, Caroline Walker, Wonderful Blood: Theology and Practice in Late Medieval Northern Germany and Beyond (Philadelphia, PA: University of Pennsylvania Press, 2007)

Ciklamini, Marlene, 'The Hand of Revision: Abbot Arngrimr's Redaction of Guðmundar saga biskups', Gripla, 8 (1993), 231-52

—_ 'Folklore and Hagiography in Arngrímr's Guðmundar saga Arasonar', in The Fantastic in Old Norse/Icelandic Literature, ed. by John McKinnell, David Ashurst and Donata Kick (Durham: The Centre for Medieval and Renaissance Studies, Durham University, 2006), pp. 171-79

Clanchy, Michael, From Memory to Written Record: England 1066-1307, 2nd edition (Oxford: Blackwell, 1993)

Cleasby, Richard and Gudbrand Vigfusson, An Icelandic-English Dictionary, 2nd edn by William A. Craigie (Oxford: Oxford University Press, 1957)

Clunies Ross, Margaret, Prolonged Echoes; Old Norse Myths in Medieval Society, vol. 2: The Reception of Norse Myths in Medieval Iceland (Odense: Odense University Press, 1998)

_ - 'The Development of Old Norse Textual Worlds: Genealogical Structure as a Principle of Literary Organization in Early Iceland', Journal of English and Germanic Philology, 92 (1993), 372-85

— - 'From Iceland to Norway: Essential Rites of Passage for an Early Icelandic Skald', Álvismál, 9 (1999), 55-72

Cormack, Margaret, The Saints in Iceland: Their Veneration from the Conversion to 1400 (Bruxelles: Société des Bollandistes, 1994) 
—, 'Saints' Lives and Icelandic Literature in the Thirteenth and Fourteenth Centuries', in Saints and Sagas, a Symposium, ed. by Hans Bekker-Nielsen and Birte Carlé (Odense: Odense University Press, 1994), pp. 27-47

Danstrup, J. et al., eds, Kulturhistorisk leksikon for nordisk middelalder fra vikingetid til reformationstid, 22 vols (Copenhagen: Rosenkilde og Bagger, 195678)

Day, Andrews, M., et al., eds., Lines of Narrative: Psychosocial Perspectives (London: Routledge, 2000)

Dictionary of Old Norse Prosel Ordbog over det norrøne prosasprog (Copenhagen: [Arnamagnæan Commission/Arnamagnæanske kommission], 1983-)

Ditchfield, Simon, ed., Christianity and Community in the West: Essays for John Bossy (Aldersholt: Ashgate, 2001)

Driscoll, Matthew, 'Late Prose Fiction (lygisögur)', in A Companion to Old NorseIcelandic Literature and Culture, ed. by Rory McTurk (Oxford: Blackwell, 2005), pp. 190-204

— - 'Pögnin mika: Hugleiðingar um riddarasögur og stöðu peirra í íslenskum bókmenntum', Skáldskaparmál, 1 (1990), 157-68

DuBois, Thomas, ed., Sanctity in the North: Saints, Lives, and Cults in Medieval Scandinavia (Toronto. ON: University of Toronto Press, 2008)

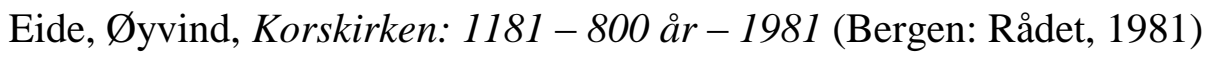

Einar Bjarnason, 'Auðbrekkubréf og Vatnfjarðarerfðir', Saga, 3 (1960-63), 371-411

—_, 'Árni Pórðarson, Smiður Andrésson og Grundar-Helga', Saga, 12 (1974), 88108

Fournier, Edouard, L'Origine du vicaire-général et des autres membres de la curie diocésaine (Paris: Chez l'auteur, 1940)

—, Les origines du vicaire-général: Étude d'histoire et de droit canon (Paris: Auguste Picard 1922)

Fournier, Paul, Les Officialités au moyen âge. Étude sur l'organisation, la compétance et la procédure des tribunaux ecclésiastiques ordinaires en France de 1180 à 1328 (Aalen: Scientia, 1984), reprint. Originally published Paris: E. Plon et Cie, 1880 
Frassetto, Michael, ed., Medieval Purity and Piety: Essays on Medieval Clerical Celibacy and Religious Reform (New York, NY: Garland, 1998)

Gaudemet, Jean, 'Le célibat ecclésiastique: Le droit et la pratique du XIe au XIIIe siècle', Zeitschrift der Savigny-Stiftung für Rechtgeschichte Kanonistische Abteilung, 68 (1982), 1-31

Geary, Patrick, Living With the Dead in the Middle Ages (Ithaca, NY: Cornell University Press, 1994)

- Phantoms of Remembrance: Memory and Oblivion at the End of the First Millennium (Princeton, NJ: Princeton University Press, 1994)

Gísli Ágúst Gunnlaugsson and Loftur Guttormsson, 'Cementing Alliances?: Witnesses to Marriage and Baptism in Early Nineteenth-century Iceland', The History of the Family, 5 (2000), 259-272

Gísli Sigurðsson, The Medieval Icelandic Saga and Oral Tradition: A Discourse on Method, trans. by Nicholas Jones, The Milman Parry Collection of Oral Literature, 2 (Cambridge, MA: Harvard University Press, 2004)

Glauser, Jürg, Isländische Märchensagas: Studien zur Prosaliteratur im spätmittelalterlichen Island, Beiträge zur nordischen Philologie, 12 (Basel: Helbing \& Lichtenhahn, 1983)

— 'Sagas of Icelanders and pattir as Literary Representations of a New Social Space', in Old Icelandic Literature and Society, ed. by Margaret Clunies Ross (Cambridge: Cambridge University Press, 2000), pp. 203-20

Guðmundur J. Guðmundsson, 'Tíu páfabréf frá 15. öld’, Saga, 46 (2008), 56-75

Guðrún Ása Grímsdóttir, 'Um afskipti erkibiskupa af íslenzkum málefnum á 12. og 13. öld', Saga, 20 (1982), 28-62

__, 'Biskupsstóll í Skálholti', in Saga Biskupsstólanna Skálholt 950 ára 2006, Hólar 900 ára, ed. by Gunnar Kristjánsson et al., (Akureyri: Hólar, 2006), pp. 21243

, 'Um íslensku prestskonuna á fyrri öldum', in Konur og Kristsmenn: Pattir úr kristnisögu Íslands, ed. by Inga Huld Hákonardóttir (Reykjavík: Háskólaútgáfan, 1996), pp. 217-47 
Guðrún Nordal, Tools of Literacy: The Role of Skaldic Verse in Icelandic Textual Culture of the Twelfth and Thirteenth Centuries (Toronto, ON: University of Toronto Press, 2001)

Guðvarður Már Gunnlaugsson, 'Manuscripts and Paleography', A Companion to Old Norse-Icelandic Literature and Culture, ed. by Rory McTurk, (Oxford: Blackwell, 2005), pp. 245-64

Gunnar F. Guðmundsson, 'Guði til pægðar eða höfðingjum í hag? Níu aldir frá lögtöku tíundar á Íslandi, Ný Saga, 9 (1997), 57-64.

—_, 'Íslenskt samfélag og Rómakirkja', in Kristni á Íslandi, 4 vols, ed. by Hjalti Hugason et al. (Reykjavík: Althingi, 2000), II, pp. 1-188

——, 'Rómaskattur og páfatíund', Ný Saga, 6 (1993), 4-15

Gunnar Karlsson, Iceland's 1100 Years: The History of a Marginal Society (Rekjavík: Mál og menning; London: Hurst, 2000)

——, 'Stofnár Pingeyrarklausturs', Saga, 46 (2008), 159-167

Gunnar Karlsson and Helgi Skúli Kjartansson, 'Plágunar miklu á Íslandi', Saga, 32 (1994), 11-74

Hagland, Jan Ragnar, Literacy i norsk seinmellomalder (Oslo: Novus, 2005)

Hallberg, Peter, Stilsignalment och författarskap i norrön saga literatur (Göteborg: Nordistica Gothenburgensis, 1968)

—, "A Group of Icelandic "Riddarasögur" from the Middle of the Fourteenth Century', in Les sagas de chevaliers (riddarasögur): actes de la Ve Conférence internationale sur les sagas, ed. by Régis Boyer (Paris: Presses de 1'Université de Paris-Sorbonne, 1985), pp. 7-56

—, 'Some Observations on the language of Dunstanus saga', Saga Book, 18 (1973), 324-53

Hamre, Lars, 'Church and Clergy', in The Cambridge History of Scandinavia, Volume I: Prehistory to 1520, ed. by Knut Helle (Cambridge: Cambridge University Press, 2003), pp. 653-75

Hamre, Lars, 'To bergenske kyrkjehovdingar, bispebrørne Arne og Audfinn', in Kongsmenn og Krossmenn: Festskrift til Grethe Authén Blom, ed. by Steinar Supphellen (Trondheim: Tapir, 1992), pp. 139-65 
Harrison, Barbara, ed., Life Story Research, 4 vols, Sage Benchmarks in Social Research Methods (London: SAGE, 2008)

Harrison, Dick, 'Quod magno nobis fuit horrori...: Horror, Power and Holiness within the Context of Canonization', in Procès de canonisation au moyen âge: Aspects juridiques et religieux, ed. by Gábor Klaniczay (Rome: École Française de Rome, 2004), pp. 39-52

Haug, Eldbjørg, 'The Icelandic Annals as Historical Sources', Scandinavian Journal of History, 22 (1997), 263-74

Heikkilä, Tuomas ed., Kirjallinen kulttuuri keskiajan Suomessa (Helsinki: Suomalaisen Kirjallisuuden Seura, 2010)

Helgi Porlaksson, ed., Church Centres: Church Centres in Iceland from the 11th to the 13th Century and their Parallels in Other Countries, Snorrastofa rit, 2 (Reykholt: Snorrastofa, 2005)

—_, 'Sagnfræði um Íslandssögu á tímabilinu 1300-1550', Saga, 38 (2000), 59-81

—_ ' 'Porgils á Pingeyrum: Um upphaf Pingeyrarklausturs', Saga, 46 (2008), 16880

Helle, Knut, Norge blir en stat: 1130-1319 (Copenhagen: Universitetsforlaget, 1974)

—, ed., The Cambridge History of Scandinavia, Volume I: Prehistory to 1520 (Cambridge: Cambridge University Press, 2003)

_- 'Norwegian Foreign Policy and the Maid of Norway', Scottish Historical Review, 69 (1990), 142-56

—, 'The Norwegian Kingdom: Succession, Disputes and Consolidation', in The Cambridge History of Scandinavia, Volume I: Prehistory to 1520, ed. by Knut Helle (Cambridge: Cambridge University Press, 2003), pp. 369-91

Hoppenbrouwers, P.C.M., 'Vengeance is Ours?: The Involvement of Kin in the Settlement of "Cases of Vengeance" in Later Medieval Holland', in Love, Marriage and Family Ties in the Middle Ages, ed. by Isabel Davis, Miriam Müller, Sarah Rees Jones (Turnhout: Brepols, 2003), pp. 241-75

Hrafnkell Lárusson and Steinunn Kristjánsdóttir, eds, Skriðuklaustur: Evrópskt miðaldaklaustur i Fljótsdal: Greinasafn (Skriðuklaustur: Gunnarsstofnun, 2008) 
Hughes, Shaun F. D., 'Klári saga as an Indigenous Romance', in Romance and Love in Late Medieval and Early Modern Iceland, ed. by Kirsten Wolf and Johanna Denzin, Islandica 54 (Ithaca, NY: Cornell University Library, 2008), pp. 135-164

Imsen, Steinar, 'King Magnus and his Liegemen's Hirdskrå: a portrait of the Norwegian nobility in the 1270s', in Nobles and Nobility in Medieval Europe. Concepts, Origins, Transformations, ed. by Anne J. Duggan (Woodbridge: Boydell, 2000), pp. 205-22

, 'Chapter 1: Introduction', in The Norwegian Dominion and the Norse World, ed. by Steinar Imsen (Trondheim: Tapir Academic Press, 2010), pp. 59-73

Jakobsen, Alfred, Studier $i$ Clarus saga: Til spфrsmålet om sagaens norske proveniens (Oslo: Universitetsforlaget, 1964)

Janus Jónsson, 'Um klaustrin á Íslandi', Tímarit Hins íslenzka bókmenntafélags, 8 (1887), 174-265

Jenkins, Keith, Rethinking History, 2nd ed. (London: Routledge, 2003)

Joys, Charles, Biskop og konge: Bispevalg i Norge 1000-1350 (Oslo: Aschehoug, 1948)

Jón Helgason, 'Introduction', in Jón Helgason ed., Biskupa sogur: MS Perg. fol. No. 5 in the Royal Library of Stockholm (Copenhagen: Einar Munksgaard, 1950), pp. $15-21$

Jón Helgason, 'Tolf annálagreinar frá myrkum árum', in Sjötíu ritgerðir: Helgaðar Jakobi Benediktssyni 20. júlí 1977, ed. by Einar G. Pétursson and Jónas Kristjánsson (Reykjavík: Stofnun Árna Magnússonar, 1977), pp. 399-418

Jón Jóhannesson, Íslendingasaga, 2 vols (Reykjavík: Almenna bókafélagið, 195658)

Jón Ólafur Ísberg, 'Lækningar, spítalar og klaustur', in Skriðuklaustur: Evrópskt miðaldaklaustur í Fljótsdal: Greinasafn, ed. by Hrafnkell Lárusson and Steinunn Kristjánsdóttir (Skriðuklaustur: Gunnarsstofnun, 2008), pp. 121-32

Jón Sigurðsson, 'Lögsögumannatal og lögmanna á Islandi. Med skýringargreinum og fylgiskjölum eptir Jón Sigurdsson', Safn til sögu Islands og islenskra bókmenta, 2, (Copenhagen: Möller, 1886) 
Jón Viðar Sigurðsson, Chieftains and Power in the Icelandic Commonwealth, trans. by Jean Lundskær-Nielsen (Odense: Odense University Press, 1999)

—, 'Island og Nidaros', in Ecclesia Nidrosiensis 1153-1537: Søkelys på Nidaroskirkens og Nidarosprovinsens historie, ed. by Steinar Imsen, Senter for middelalderstudier, 15 (Trondheim: Tapir, 2003), pp. 120-40

- 'The Icelandic Aristocracy after the fall of the Free State', Scandinavian Journal of History, 20 (1995), 153-66

—, 'Islandske storkirker før 1300', in Church Centres: Church Centres in Iceland from the 11th to the 13th Century and their Parallels in Other Countries, ed. by Helgi Porláksson, Snorrastofa rit, 2 (Reykholt: Snorrastofa, 2005), pp, 161-70

—, 'The Norse Community', in The Norwegian Dominion and the Norse World, ed. by Steinar Imsen (Trondheim: Tapir Academic Press, 2010), pp. 59-73

—_ 'Samskipti íslenskra biskupa við útlenda yfirboðara á öldum áður', in Saga Biskupsstólanna Skálholt 950 ára 2006, Hólar 900 ára, ed. by Gunnar Kristjánsson et al., (Akureyri: Hólar, 2006), pp. 490-515

Jónas Kristjánsson, ‘Annálar og Íslendingasögur’, Gripla, 4 (1980), 295-314

Jónas Kristjánsson, 'Bókmenntasaga', in Saga Íslands: Samin að tilhlutan Pjóðhátíðarnefndar 1974, ed. by Sigurður Lindal (Reykjavík: Hið íslenzka bókmenntafélag, 1974-90), III (1978), pp. 261-350

Jorgensen, Peter Alvin, 'Ten Icelandic Exempla and their Middle English Source', Opuscula, 4 (1970), 177-207

Jørgensen, J.H., 'Forord', in Historien om biskop Laurentius på Holar, trans. by J.H. Jørgensen (Odense: Odense universitetsforlag, 1996)

—

Jørgensen, Torstein, 'Law and Violence in the Middle Ages', available at: <http://www.wun. ac.uk/external/lvma/index.html> [accessed 8 November 2011]

Jütte, Robert, Poverty and Deviance in Early Modern Europe (Cambridge: Cambridge University Press, 1994)

Kalinke, Marianne, The Book of Reykjarhólar: The Last of the Great Medieval Legendaries (Toronto, ON: University of Toronto Press, 1996) 
-, 'Clári saga: A Case of Low German Infiltration', Scripta Islandica, 59 (2008), 5-25

Kemp, E.W., Canonization and Authority in the Western Church (Oxford: Oxford University Press, 1948)

Klanziczay, Gábor, 'Proving Sanctity in the Canonization Processes: Saint Elizabeth and Saint Margaret of Hungary', in Procès de canonisation au moyen âge: aspects juridiques et religieux, ed. by Gábor Klanziczay (Rome: École Française de Rome, 2004), pp. 117-48

Lára Magnúsardóttir, Bannfaring og kirkjuvald á Íslandi 1275-1550: Lög og rannsóknarforsendur (Reykjavík: Háskólaútgáfan, 2007)

Lindow, John, 'Páttr', in Medieval Scandinavia: An Encyclopedia, ed. by Philip Pulsiano and Kirsten Wolf (New York, NY: Garland, 1993), pp. 661-62

Magerøy, Hallvard, 'Diplomatics', in Medieval Scandinavia: An Encyclopedia, ed. by Philip Pulsiano and Kirsten Wolf (New York, NY: Garland, 1993), pp. 137-38

Magnús Lyngdal Magnússon, “"Kátt er peim af kristinrétti, kærur vilja margar læra: Af kristinrétti Árna, setning hans og valdsviði', Gripla, 15 (2004), 43-90

Magnús Stefansson, Staðir og staðamál: Studier i islandske egenkirkelige og beneficialrettslige forhold (Bergen: Universitetet i Bergen, Historisk institutt, 2000)

— , 'Bergen, Islands første hovedstad', in Kjфpstad og rikssentrum, ed. by Ingvild Øye, Onsdagskvelder i Bryggens museum, 2 (Bergen: Bryggens museum, 1986), pp. 70-87

—_, 'Frá goðakirkju til biskupskirkju í íslenzkum búningi', in Saga Íslands: Samin að tilhlutan Pjóðhátíðarnefndar 1974, ed. by Sigurður Lindal (Reykjavík: Hið íslenzka bókmenntafélag, 1974-90), III (1978), pp. 111-257

—_, 'Kirkjuvald eflist', in Saga Íslands: Samin að tilhlutan Pjóðhátíðarnefndar 1974, 5 vols, ed. by Sigurður Lindal (Reykjavík: Hið íslenzka bókmenntafélag, 1974-90), II (1974), pp. 55-144

Marteinn Sigurðsson, “Djöfullinn gengur um sem öskrandi ljón”: Af Jóni Halldórssyni Skálholtsbiskupi, Francesco Petrarca og fornu ljónahliði dómkirkjunnar í Bologna', Skirnir, 2004 (178) 341-48 
Maurer, Konrad von, 'Der Elisabeth von Schönau Visionen nach einer isländischen Quelle', (published lecture, Philosophisch-philologische Classe, Meeting from 7 July 1883), in Sitzungsberichte der philosophisch-philologischen und historischen Classe der k. b. Akademie der Wissenschaften (Munich: Straub, 1884), pp. 401-23

McKitterick, Rosamond, 'Roman Texts and Roman History in the Early Middle Ages', in Rome Across Time and Space: Cultural Transmission and the Exchange of Ideas c. 500-1400, ed. by Claudia Bolgia, Rosamond McKitterick, and John Osborne (Cambridge, Cambridge University Press, 2011), pp. 19-34

Miller, William Ian, Bloodtaking and Peacemaking: Feud, Law and Society in Saga Iceland (Chicago, IL: University of Chicago Press, 1990)

and England', Law and History Review, 1 (1983), 159-204

Mollat, G., The Popes at Avignon 1305-1378, trans. by Janet Love (Edinburgh: Nelson and Sons, 1963)

Morris, Colin, The Papal Monarchy: The Western Church from 1050 to 1250 (Oxford: Clarendon Press, 2001)

Nedkvitne, Arneved, The Social Consequences of Literacy in Medieval Scandinavia, Utrecht Studies in Medieval Literacy, 11 (Turnhout: Brepols, 2004)

Nicholas, David, The Northern Lands: Germanic Europe, c. 1270-c. 1500 (Malden, MA: Wiley-Blackwell, 2009)

- The Van Arteveldes of Ghent: The Varieties of Vendetta and the Hero in History (Ithaca, NY: Cornell University Press, 1988)

Oleson, Jens E., 'Inter-Scandinavian Relations', in The Cambridge History of Scandinavia, Volume I: Prehistory to 1520, ed. by Knut Helle (Cambridge: Cambridge University Press, 2003), pp. 710-70

Orrman, Eljas, 'Church and Society', in The Cambridge History of Scandinavia, Volume I: Prehistory to 1520, ed. by Knut Helle (Cambridge: Cambridge University Press, 2003), pp. 421-62

Orri Vésteinsson, The Christianization of Iceland: Priests, Power and Social Change 1000-1300 (Oxford: Oxford University Press, 2000)

Pantin, W.A., The English Church in the Fourteenth Century (Cambridge: Cambridge University Press, 1955) 
- 'The Fourteenth Century', in The English Church and the Papacy in the Middle Ages, ed. by C.H. Lawrence (Stroud: Sutton, 1999)

Pennington, Kenneth, Pope and Bishops: The Papal Monarchy in the Twelfth and Thirteenth Centuries (Philadelphia, PA: University of Pennsylvania Press, 1984)

Portelli, Alessandro, The Death of Luigi Trastulli and Other Stories; Form and Meaning in Oral History (Albany, NY: State University of New York Press, 1991)

Ranković, Slavica, Leidulf Melve, and Else Mundal, eds, Along the Oral-Written Continuum: Types of Texts, Relations and their Implications, Utrecht Studies in Medieval Literacy, 20 (Turnhout: Brepols, 2010)

Renouard, Yves, The Avignon Papacy 1305-1403, trans. by Denis Bethell (London: Faber, 1970)

Rowe, Elizabeth Ashman, The Development of Flateyarbók: Iceland and the Norwegian Dynastic Crisis of 1389 (Odense: University Press of Southern Denmark, 2005)

—, 'The Flateyarbók Annals as a Historical Source', Scandinavian Journal of History, 27 (2002), 233-42

Sandvik, Gudmund and Jón Viðar Sigurðsson, 'Laws', in A Companion to Old Norse-Icelandic Literature and Culture, ed. by Rory McTurk (Oxford: Blackwell, 2005), pp. 223-44

Sawyer, Birgit and Peter Sawyer, 'Scandinavia Enters Christian Europe', in The Cambridge History of Scandinavia, Volume I: Prehistory to 1520, ed. by Knut Helle (Cambridge: Cambridge University Press, 2003), pp. 147-59

Schimmelpfennig, Bernhard, 'Ex fornicatione nati: Studies on the Position of Priests' Sons from the Twelfth to the Fourteenth Century', Studies in Medieval and Renaissance History, 2nd series, 2 (1979), 3-50

Schmugge, Ludwig, Kirche, Kinder, Karrieren: Päpstliche Dispense von der unehelichen Geburt im Spätmittelalter (Zürich: Artemis \& Winkler, 1995)

Seaver, Kirsten A., The Frozen Echo; Greeland and the Exploration of North America ca A.D. 1000-1500 (Stanford, CA: Stanford University Press, 1996) 
Sigríður Júlíusdóttir , 'The Major Churches in Iceland and Norway; A Study into the Major Churches in Skálholt and Bergen Diocese in the 11th to the 15th Centuries', (unpublished master's thesis, University of Bergen, 2006)

Sigríður Sigurðardóttir, Glaumbar: Kirkja og Staðir (Varmahlíð: Byggðasafn Skagfirðinga, 2008)

Sigurður Líndal, 'Utanríkisstefna Íslendinga á 13. öld og aðdragandi sáttmálans 1262-64', Úlfljótur, 17 (1964), 5-36

Skórzewska, Joanna, Constructing a Cult: The Life and Veneration of Guðmundr Arason (11611-237) in the Icelandic Written Sources, The Northern World, 51 (Leiden: Brill, 2011)

Skúli Kjartanson, 'Thin on the Ground: Legal Evidence of the Availability of Priests in 12th Century Iceland', in Church Centres: Church Centres in Iceland from the 11th to the 13th Century and their Parallels in Other Countries, ed. by Helgi Porlaksson, Snorrastofa rit, 2 (Reykholt: Snorrastofa, 2005), pp. 95-102

Smith, David M., 'The Officialis of the Bishop in Twelfth- and Thirteenth-Century England: Problems of Terminology', in Medieval Ecclesiastical Studies in Honour of Dorothea M. Owen, ed. by M.J. Franklin and Christopher Harper-Bill, Studies in the History of Medieval Religion, 7 (Woodbridge: Boydell and Brewer, 1995), 201-220

Southern, Richard, Saint Anselm: A Portrait in a Landscape (Cambridge: Cambridge University Press, 1990)

- Saint Anselm and his Biographer: A Study of Monastic Life and Thought, 1059-c. 1130 (Cambridge: Cambridge University Press, 1963)

Spiegel, Gabrielle, The Past as Text: The Theory and Practice of Medieval Historiography (Baltimore, NJ: Johns Hopkins University Press, 1997)

Stefán Karlsson, 'Guðmundar Sögur Biskups: Authorial Viewpoints and Methods' in Stafkrókar, ed. by Guðvarður Már Gunnlaugsson (Reykjavík: Stofnun Árna Magnússonar á Íslandi, 2000), pp. 153-71

—_, 'Islandsk bogeksport til Norge i middelalderen', in Stafkrókar, ed. by Guðvarður Már Gunnlaugsson (Reykjavík: Stofnun Árna Magnússonar á Íslandi, 2000), pp. 188-205 
, 'Icelandic Lives of Thomas à Becket: Questions of Authorship', in Stafkrókar, ed. by Guðvarður Már Gunnlaugsson (Reykjavík: Stofnun Árna Magnússonar á Íslandi, 2000), pp. 153-71

Steinunn Kristjánsdóttir, "'Svo á jörðu sem á himni'”: Minningarbrot frá Skirðulaustri í Fljótsdal’, Ritröð Guðfræðistofununar, 29 (2009), 151-71

Svanhildur Óskarsdóttir, 'Arctic Garden of Delights: The Purpose of the Book of Reynistaður', in Romance and Love in Late Medieval and Early Modern Iceland, ed. by Kirsten Wolf and Johanna Denzin, Islandica 54 (Ithaca, NY: Cornell University Library, 2008), pp. 279-302

Sveinbjörn Rafnsson, Páll Jónsson Skálholtsbiskup: Nokkrar athugarnir á sögu hans og kirkjustjórn (Reykjavík: Ritsafn Sagnfræðistofnunar, 1993)

Sveinn Nielsson, Prestatal og prófasta á Íslandi, 2nd edn (Reykjavík: Híð íslenzka bókmenntafélag, 1950)

Sverrir Jakobsson, 'Strangers in Icelandic Society 1100-1400', Viking and Medieval Scandinavia, 3 (2007), 141-57

__ 'Pegar Ísland varð hluti af Noregi: Hugleiðing um valkosti sögunnar', Skírnir, 181 (2007), 151-66

Sverrir Tómasson, 'Trúarbókmenntir í lausu máli á síðmiðöld', in Íslensk bókmenntasaga, 3 vols, ed. by Guðrún Nordal, Sverrir Tómasson and Vésteinn Ólason (Reykjavík: Mál og menning, 1992-), I, pp. 265-418

—_, 'Veraldlega sagnarítun', in Íslensk bókmenntasaga, 3 vols, ed. by Guðrún Nordal, Sverrir Tómasson and Vésteinn Ólason (Reykjavík: Mál og menning, 1992-), I, pp. 265-418

Swanson, R.N., Church and Society in Late Medieval England (Oxford: Basil Blackwell, 1989)

- ed., Promissory Notes on the Treasury of Merits: Indulgences in Late Medieval Europe (Leiden: Brill, 2006)

Taglia, Kathryn Ann, “'On Account of Scandal...": Priests, Their Children, and the Ecclesiastical Demand for Celibacy’, Florilegium, 14 (1995-96), 57-70

Taylor, John, English Historical Literature in the Fourteenth Century (Oxford: Clarendon, 1987) 
Taylor, Marvin, 'On Gizzur Porvaldsson's Speaking Style', Saga-Book, 24 (1997), 311-28

Thompson, A.H., 'Diocesan Organisation in the Middle Ages: Archdeacons and Rural Deans', Proceedings of the British Academy, 29 (1943), 153-94

Torfi H. Tulinius, 'Saga as a Myth: The Family Sagas and Social Reality in 13thcentury Iceland', Old Norse Myths, Literature \& Society: $11^{\text {th }}$ international Saga Conference, (Sydney: Centre for Medieval Studies, University of Sidney, 2000), pp. 526-39

Tosh, John, The Pursuit of History: Aims, Methods and New Directions in the Study of Modern History, 3d ed. (Harlow: Longman, 2000)

'Tutorial on Books of Hours', Centre for Håndskriftstudier i Danmark, <http://www.chd.dk/ tutor/spiritusmh.html>, accessed 9 November 2011

Úlfar Bragason, 'The Politics of Genealogies in Sturlunga saga', in Scandinavia and Europe 800-1350, ed. by Jonathan Adams and Katherine Holman, Medieval Texts and Cultures of Northern Europe, 4 (Turnhout, Brepols, 2004), pp. 309-21

—_, 'Sagas of Contemporary History', in A Companion to Old Norse-Icelandic Literature and Culture, ed. by Rory McTurk, (Oxford: Blackwell, 2005), pp. 42746

__, Sturlunga saga: Textar og rannsóknir', Skáldskaparmál, 2 (1992), 176-206

Vauchez, André, Sainthood in the Later Middle Ages, trans. by Jean Birrell (Cambridge: Cambridge University Press, 1997)

—_, 'La question du célibat ecclésiastique dans l'Occident médiéval: Un état de la recherche', in Medieval Spirituality in Scandinavia and Europe: A Collection of Essays in Honour of Tore Nyberg, ed. by Lars Bisgaard and others (Odense: Odense University Press, 2001), pp. 23-32

Vésteinn Ólason, Dialogues with the Viking Age: Narration and Representation in the Sagas of the Icelanders, trans. by Andrew Wawn (Reykjavík: Mál og Menning, 1998)

— , 'The Fantastic Element in Fourteenth-Century Íslendingasögur', Gripla, 18 (2007), 7-22

Vilborg Auður Ísleifsdóttir, Siðbreytingin á Íslandi 1537-1565: Byltingin að ofan (Reykjavik: Hið Íslenska Bókmenntafélag, 1997) 
White, Hayden, Tropics of Discourse: Essays in Cultural Criticism (Baltimore, NJ: Johns Hopkins University Press, 1978)

Wolf, Kirsten, 'Pride and Politics in Iceland: The Sanctity of Bishop Porlákr Pórhallsson', in Sanctity in the North: Saints, Lives, and Cults in Medieval Scandinavia, ed. by Thomas DuBois (Toronto. ON: University of Toronto Press, 2008), pp. 241-70

Zutshi, Patrick, 'Chapter 19: The Avignon Papacy', in The New Cambridge Medieval History, vol. 6, ed. by Michael Jones (Cambridge: Cambridge University Press, 2000), pp. 653-67 


\section{Appendices}

\section{Appendix 1: Bishops of Skálholt and Hólar, 1056-1550}

Table 7. Bishops of Skálholt: 1056-1540

\begin{tabular}{|l|l|}
\hline DATE & NAME \\
\hline $1056-1080$ & Ísleifr Gizzurarson \\
\hline $1082-1118$ & Gizzur Ísleifsson \\
\hline $1118-1133$ & Porlákr Runólfsson \\
\hline $1134-1148$ & Magnús Einarsson \\
\hline $1152-1176$ & Klængr Porsteinsson \\
\hline $1178-1193$ & Porlákr helgi Pórhallsson \\
\hline $1195-1211$ & Páll Jónsson \\
\hline $1216-1237$ & Magnús Gizzurarson \\
\hline $1238-1268$ & Sigvarðr Péttmarsson \\
\hline $1269-1298$ & Árni Porláksson \\
\hline $1304-1320$ & Árni Helgason \\
\hline $1321-1321$ & Grímr Skútuson \\
\hline $1322-1339$ & Jón Halldórsson \\
\hline $1339-1341$ & Jón Indriðason \\
\hline $1343-1348$ & Jón Sigurðsson \\
\hline $1350-1360$ & Gyrðir Ívarsson \\
\hline $1362-1364$ & Pórarinn Sigurðsson \\
\hline $1365-1381$ & Oddgeir Porsteinsson \\
\hline $1382-1391$ & Mikael \\
\hline $1391-1405$ & Vilchin Hinriksson \\
\hline $1406-1413$ & Jón \\
\hline $1413-1426$ & Árni Ólafsson \\
\hline $1426-1433$ & Jón Gerreksson \\
\hline $1435-1437$ & Jón Vilhjálmsson Craxton \\
\hline $1437-1447$ & Gozewijn Comhaer \\
\hline $1448-1462$ & Marcellus \\
\hline $1462-1465$ & Jón Stefánsson Krabbe \\
\hline $1466-1475$ & Sveinn spaki Pétursson \\
\hline $1477-1490$ & Magnús Eyjólfsson \\
\hline $1491-1518$ & Stefán Jónsson \\
\hline $1521-1540$ & Ögmundur Pálsson \\
\hline
\end{tabular}

${ }^{1}$ The information in these tables is taken from Gunnar Kristjánsson et al., eds, Saga biskupsstólanna: Skálholt 950 ára 2006, Hólar 900 ára (Akureyri: Hólar, 2006), pp. 854-55. 
Table 8. Bishops of Hólar: 1106-1550

\begin{tabular}{|l|l|}
\hline DATE & NAME \\
\hline $1106-1121$ & Jón Ögmundsson \\
\hline $1122-1145$ & Ketill Porsteinsson \\
\hline $1147-1162$ & Björn Gilsson \\
\hline $1163-1201$ & Brandr Sæmundsson \\
\hline $1203-1237$ & Guðmundr góði Arason \\
\hline $1238-1247$ & Bótólfr \\
\hline $1247-1260$ & Heinrekr Kársson \\
\hline $1263-1264$ & Brandr Jónsson \\
\hline $1267-1313$ & Jörundr Porsteinsson \\
\hline $1313-1322$ & Auðunn rauði \\
\hline $1324-1331$ & Lárentíus Kálfsson \\
\hline $1332-1341$ & Egill Eyjólfsson \\
\hline $1342-1356$ & Ormr Ásláksson \\
\hline $1358-1390$ & Jón skalli Eiríksson \\
\hline $1391-1411$ & Pétr Nikulásson \\
\hline $1411-1423$ & Jón Tófason (Henriksson) \\
\hline $1425-1435$ & Jón Vilhjálmsson \\
\hline $1435-1440$ & Jón Bloxwich \\
\hline $1441-1441$ & Róbert Wodbor \\
\hline $1442-1457$ & Gottskálk Keneksson \\
\hline $1458-1495$ & Ólafur Rögnvaldsson \\
\hline $1496-1520$ & Gottskálk grimmi Nikulásson \\
\hline $1524-1550$ & Jón Arason \\
\hline
\end{tabular}




\section{Appendix 2: The officiales and ráðsmenn of Skálholt and Hólar}

Table 9. Officiales of Skálholt ${ }^{2}$

\begin{tabular}{|c|c|c|c|c|}
\hline NAME & DATES & $\begin{array}{l}\text { OCCASION OF } \\
\text { APPOINTMENT }\end{array}$ & $\begin{array}{l}\text { Sede Vacante } \\
\text { or permanent }\end{array}$ & SOURCE \\
\hline $\begin{array}{l}\text { Sigmundr } \\
\text { Einarsson }\end{array}$ & 1340,1341 & $\begin{array}{l}\text { death of Bishop } \\
\text { Jón Indriðason }\end{array}$ & $\begin{array}{l}\text { permanent, } \\
\text { sede vacante }\end{array}$ & annal, DI \\
\hline $\begin{array}{l}\text { Brother } \\
\text { Eysteinn }\end{array}$ & 1349 & $\begin{array}{l}\text { appt. by Bishop } \\
\text { Gyrðr in Norway }\end{array}$ & $?$ & annal \\
\hline $\begin{array}{l}\text { Snorri kyngir } \\
\text { Porleifsson }\end{array}$ & 1355 & $\begin{array}{l}\text { Bishop Gyrðr's } \\
\text { journey to Norway }\end{array}$ & Sede vacante & annal \\
\hline $\begin{array}{l}\text { Brother } \\
\text { Eysteinn }\end{array}$ & 1359 & $\begin{array}{l}\text { given 'officiatolus } \\
\text { starf' in the } \\
\text { Westfjords by } \\
\text { Bishop Gyrðr }\end{array}$ & permanent? & annal \\
\hline $\begin{array}{l}\text { Snorri kyngir } \\
\text { Porleifsson }\end{array}$ & $\begin{array}{l}\text { 1360-63; } \\
\text { again 1366-79 } \\
\text { (died) }\end{array}$ & $\begin{array}{l}\text { death of Bishop } \\
\text { Gyrðr }\end{array}$ & $\begin{array}{l}\text { Sede vacante, } \\
\text { permanent }\end{array}$ & annal, DI \\
\hline $\begin{array}{l}\text { Ari } \\
\text { Gunnlaugsson }\end{array}$ & $\begin{array}{l}1388-89 \\
\text { (died) }\end{array}$ & Bishop Michael & & annal \\
\hline Páll & 1384 & unknown & unknown & annal \\
\hline no officialis & 1390 & $\begin{array}{l}\text { bishopless in } \\
\text { Iceland }\end{array}$ & 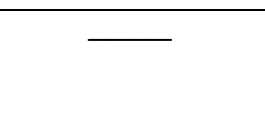 & annal \\
\hline $\begin{array}{l}\text { Porsteinn } \\
\text { Snorrason }\end{array}$ & $\begin{array}{l}\text { 1391-93 (or } \\
\text { later) }\end{array}$ & $\begin{array}{l}\text { Michael (also app. } \\
\text { abbot of Helg. } \\
\text { same year) }\end{array}$ & & annal \\
\hline $\begin{array}{l}\text { Porsteinn } \\
\text { Svarthöfðason }\end{array}$ & 1398 & unknown & & DI \\
\hline $\begin{array}{l}\text { Óli } \\
\text { Svarthöfðason }\end{array}$ & 1399 (d. 1402) & unknown & & DI \\
\hline $\begin{array}{l}\text { Vermundr, } \\
\text { Oddr Jónsson, } \\
\text { Pórarinn } \\
\text { Andréssson }\end{array}$ & $1405-08$ & $\begin{array}{l}\text { Bishop Vilchin } \\
\text { (three officiales } \\
\text { appointed) }\end{array}$ & permanent & annal, DI \\
\hline
\end{tabular}

${ }^{2}$ Sigmundr Einarsson: Skálholtsannáll, p. 209, DI II, p.734; Eysteinn: Gottskálksannáll, pp. 354, 358; Snorri kyngir Porleifsson: Gottskálksannáll, p. 356; Flateyjarannáll, p. 411, Lögmannsannáll, pp. 281, 412; DI III, pp. 146-47 (1360), 181-82 (1361), 199-200, 211 (1366); Ari Gunnlaugsson, Lögmannsannáll, pp. 283-84, Gottskálksannáll, p. 366; Porsteinn Snorrason: Gottskálksannáll, p. 367, Flateyjarannáll, pp. 414, 417; Porsteinn Svarthöfðason: DI III, pp. 634-35 (1398); Óli Svarthöfðason: DI III, pp. 648-49 (1399); Vermundr, Oddr, Pórarinn: Lögmannsannáll (Ný Annáll), p. 287; Vermundr: DI III, pp. 708-09 (1406). 
Table 10. Ráðsmenn of Skálholt ${ }^{3}$

\begin{tabular}{|l|l|l|l|}
\hline NAME & DATE & $\begin{array}{l}\text { OCCASION OF } \\
\text { APPOINTMENT }\end{array}$ & SOURCE \\
\hline Jón Skúmason & before 1270 & $\begin{array}{l}\text { before Árni } \\
\text { Pórláksson }\end{array}$ & Árna saga \\
\hline Loftr Helgason & c. 1270-98 [?] & Árni Pórláksson & Árna saga \\
\hline Eyjólfr & 1340 & unknown & DI \\
\hline Flósi Jónsson & 1360 & $\begin{array}{l}\text { death of Bishop } \\
\text { Gyror }\end{array}$ & annal \\
\hline Oddr Teitsson & $1388-93$ (at least) & $\begin{array}{l}\text { app. by Bishop } \\
\text { Michael }\end{array}$ & annal \\
\hline Halldorr Jónsson & 1398 & d. 1402 & DI \\
\hline Höskuldr & until 1405 & annal \\
\hline $\begin{array}{l}\text { Vigfúss } \\
\text { Porbjarnarson }\end{array}$ & $1405-$ fall of 1409 & $\begin{array}{l}\text { annal } \\
\text { Oave up position } \\
\text { Oddr Jónsson }\end{array}$ & annal \\
\hline $\begin{array}{l}\text { Guðmundr } \\
\text { Porsteinsson }\end{array}$ & $\begin{array}{l}\text { year) } \\
\text { Christmas of next }\end{array}$ & annal & annal \\
\hline $\begin{array}{l}\text { Vigfúss } \\
\text { Porbjarnason }\end{array}$ & $\begin{array}{l}\text { Christmas 1409- } \\
\text { Jón Porsteinsson }\end{array}$ & 1412 & DI \\
\hline
\end{tabular}

3 Árna saga, pp. 21, 104; Gottskálksannáll, p. 356, Lögmannsannáll, pp. 283-84, Gottskálksannáll, p. 366, Lögmannsannáll (Ný Annáll), pp. 286-87, 289-90. DI II, p. 734; DI III, pp. 634-35, 742. 
Table 11. Officiales of Hólar ${ }^{4}$

\begin{tabular}{|c|c|c|c|c|c|}
\hline NAME & DATES & BISHOP & $\begin{array}{l}\text { OCCASION OF } \\
\text { APPOINTMENT }\end{array}$ & $\begin{array}{l}\text { Sede } \\
\text { Vacante or } \\
\text { permanent }\end{array}$ & SOURCE \\
\hline $\begin{array}{l}\text { Halldórr } \\
\text { Grímsson }\end{array}$ & 1290 & Jörundr & $\begin{array}{l}\text { Bishop to Norway } \\
\text { (stayed for } 2 \\
\text { years) }\end{array}$ & $\begin{array}{l}\text { Sede } \\
\text { vacante }\end{array}$ & Lárentíus saga \\
\hline $\begin{array}{l}\text { Porsteinn } \\
\text { skarðsteinn } \\
\text { Illugason }\end{array}$ & 1313 & Jörundr & Death of bishop & $\begin{array}{l}\text { Sede } \\
\text { vacante }\end{array}$ & Lárentíus saga \\
\hline $\begin{array}{l}\text { Porsteinn } \\
\text { Illugason }\end{array}$ & $1321-22$ & Auðunn & $\begin{array}{l}\text { Bishop to } \\
\text { Norway; death of } \\
\text { bishop }\end{array}$ & $\begin{array}{l}\text { Sede } \\
\text { vacante }\end{array}$ & Lárentíus saga \\
\hline $\begin{array}{l}\text { Porsteinn } \\
\text { Illugason }\end{array}$ & 1330 & Lárentíus & Death of bishop & $\begin{array}{l}\text { Sede } \\
\text { vacante }\end{array}$ & Lárentíus saga \\
\hline $\begin{array}{l}\text { Einar } \\
\text { Hafliðason }\end{array}$ & 1341 & Egill & Death of bishop & $\begin{array}{l}\text { Sede } \\
\text { vacante }\end{array}$ & annal \\
\hline $\begin{array}{l}\text { Arngrímr } \\
\text { Brandsson } \\
{[?]}\end{array}$ & $\begin{array}{l}\text { before } \\
1357\end{array}$ & Ormr & & - & [annal] \\
\hline $\begin{array}{l}\text { Porsteinn } \\
\text { Hallsson }\end{array}$ & $1357-59$ & None & priests' synod & $\begin{array}{l}\text { Sede } \\
\text { vacante }\end{array}$ & annal \\
\hline $\begin{array}{l}\text { Einarr } \\
\text { Hafliðason }\end{array}$ & 1370 & Jón skalli & Bishop to Rome & $\begin{array}{l}\text { Sede } \\
\text { vacante }\end{array}$ & annal \\
\hline $\begin{array}{l}\text { Einarr } \\
\text { Hafliðason }\end{array}$ & $1375-93$ & Jón skalli & $\begin{array}{l}\text { Return of Jón } \\
\text { skalli. Gave up } \\
\text { office in } 1393 .\end{array}$ & permanent & annal, DI, \\
\hline $\begin{array}{l}\text { Jón } \\
\text { Magnússon }\end{array}$ & 1393 & Pétr & Retirement of EH. & permanent & annal \\
\hline $\begin{array}{l}\text { Pórðr } \\
\text { Pórðarson }\end{array}$ & $\begin{array}{l}1396-99 \\
\text { (died } \\
1402)\end{array}$ & Pétr & - & permanent? & DI \\
\hline $\begin{array}{l}\text { Steinmóðr } \\
\text { Porsteins- } \\
\text { son } \\
\end{array}$ & $\begin{array}{l}1398- \\
1404 \text { (d.) }\end{array}$ & Pétr & - & permanent & DI \\
\hline $\begin{array}{l}\text { Logi } \\
\text { Stígsson }\end{array}$ & $\begin{array}{l}1406-08 \\
\text { (or later) }\end{array}$ & Pétr & 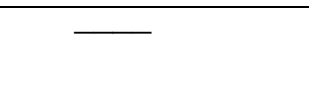 & Permanent & DI \\
\hline
\end{tabular}

${ }^{4}$ Lárentíus saga, pp. 232, 314-18, 320-21, 342, 353, 437, 439; Brot af Skálholtsannáll, p. 225; Flateyjarannáll, pp. 405-06, 419, 420 Lögmannsannáll, pp. 273, 280; Gottskálksannáll, p. 352. Einarr Hafliðason: DI III, p. 339 (1379), pp. 387-89 (1386); Pórðr Pórðarson: DI III, p. 611 (1396); Steinmóðr Porsteinsson: DI III, p. 627-30 (1398), DI IV, pp. 240-41; Logi Stígsson: DI III, p. 709 (1406), 711 (1406), 717 (1408). 
Table 12. Ráðsmenn of Hólar ${ }^{5}$

\begin{tabular}{|c|c|c|c|c|}
\hline NAME & DATE & UNDER & $\begin{array}{l}\text { OCCASION OF } \\
\text { APPOINTMENT }\end{array}$ & SOURCE \\
\hline $\begin{array}{l}\text { Hafliði } \\
\text { Steinsson }\end{array}$ & 1290 & Jörundr & - & $\begin{array}{l}\text { Lárentíus } \\
\text { saga }\end{array}$ \\
\hline Skúli Ingason & $\begin{array}{l}\text { c. } 1322-30 \\
\text { (and before } \\
1314 \text { ) }\end{array}$ & $\begin{array}{l}\text { Jörundr, } \\
\text { Lárentíus }\end{array}$ & - & $\begin{array}{l}\text { Lárentíus } \\
\text { saga, DI }\end{array}$ \\
\hline $\begin{array}{l}\text { Kolbeinn } \\
\text { Porsteinsson }\end{array}$ & $\begin{array}{l}{[1332 ?]-} \\
1340(\text { died })\end{array}$ & Egill & $\begin{array}{l}\text { Acquired } \\
\text { agreement to deed } \\
\text { of sale between } \\
\text { Egill and a farmer }\end{array}$ & DI \\
\hline $\begin{array}{l}\text { Einar } \\
\text { Hafliðason }\end{array}$ & $1340 / 1341$ & Egill & Death of Kolbeinn & annal \\
\hline $\begin{array}{l}\text { Einarr } \\
\text { Hafliðason }\end{array}$ & 1370 & Jón skalli & $\begin{array}{l}\text { Bishop Jón's } \\
\text { journey to Rome }\end{array}$ & annal \\
\hline $\begin{array}{l}\text { Einarr } \\
\text { Hafliðason }\end{array}$ & $1375-76$ & Jón skalli & $\begin{array}{l}\text { Arrival of Jón skalli } \\
\text { in Iceland }\end{array}$ & annal \\
\hline $\begin{array}{l}\text { Porsteinn } \\
\text { Jónsson }\end{array}$ & $\begin{array}{l}1376-79, \\
\text { poss. to } 1391\end{array}$ & Jón skalli & E.H. gave up office & annal \\
\hline $\begin{array}{l}\text { Pórðr } \\
\text { Pórðarson }\end{array}$ & $1386-92$ & Jón skalli/Pétr & $\begin{array}{l}\text { Representing Hólar } \\
\text { in legal case; keeps } \\
\text { position upon } \\
\text { arrival of Bishop } \\
\text { Pétr }\end{array}$ & $\begin{array}{l}\text { DI (see also } \\
\text { Appendix } \\
3.2 \text { ) }\end{array}$ \\
\hline $\begin{array}{l}\text { Pórðr } \\
\text { Pórðarson }\end{array}$ & 1392 & Jón skalli/Pétr & & $\begin{array}{l}\text { annal (see } \\
\text { section } \\
4.3 .2)\end{array}$ \\
\hline $\begin{array}{l}\text { Steinmóðr } \\
\text { Porsteinsson }\end{array}$ & $\begin{array}{l}\text { 1395-96 (or } \\
\text { later; died } \\
1404)\end{array}$ & Pétr & & DI \\
\hline $\begin{array}{l}\text { Halldórr } \\
\text { Loftsson }\end{array}$ & $\begin{array}{l}1381(\mathrm{~d} . \\
1403)\end{array}$ & & & annal \\
\hline
\end{tabular}

5 Lárentíus saga, pp. 232, 322, 354, 436-38; Lögmannsannáll, pp. 273, 280-281, Flateyjarannáll, pp. 413, 419, 420; DI II, pp. 581, 675, DI III, pp. 387-89, DI III, pp. 603, 611. 